
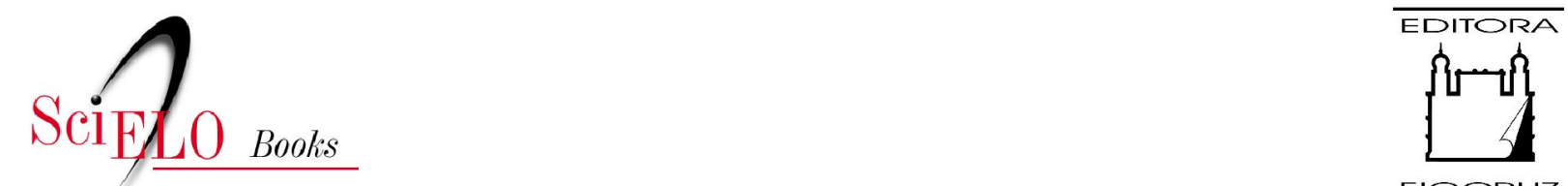

FIOCRUZ

\title{
A recepção do Darwinismo no Brasil
}

\author{
Heloisa Maria Bertol Domingues \\ Magali Romero Sá \\ Thomas Click
}

(orgs.)

DOMINGUES, HMB., SÁ, MR., and GLICK, T., orgs. A recepção do Darwinismo no Brasil [online]. Rio de Janeiro: Editora FIOCRUZ, 2003, 189 p. História e saúde collection. ISBN 978-85-7541-496-

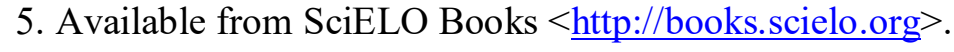

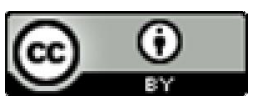

All the contents of this work, except where otherwise noted, is licensed under a Creative Commons Attribution $\underline{4.0 \text { International license. }}$

Todo o conteúdo deste trabalho, exceto quando houver ressalva, é publicado sob a licença Creative Commons Atribição 4.0.

Todo el contenido de esta obra, excepto donde se indique lo contrario, está bajo licencia de la licencia Creative Commons Reconocimento 4.0. 


\section{FUNDAÇÃO OSWALDO CRUZ}

Presidente

Paulo Marchiori Buss

Vice-Presidente de Desenvolvimento Institucional, Informação e Comunicação

Paulo Gadelha

\section{EDITORA FIOCRUZ}

Coordenador

Paulo Gadelha

Conselho Editorial

Carlos E. A. Coimbra Jr:

Carolina M. Bori

Charles Pessanha

Jaime L. Benchimol

José da Rocha Carvalheiro

José Rodrigues Coura

Luis David Castiel

Luiz Fernando Ferreira

Maria Cecilia de Souza Minayo

Miriam Struchiner

Paulo Amarante

Vanize Macêdo

Coordenador Executivo

João Carlos Canossa P. Mendes

Coleção História e Saúde

Editores Responsáveis: Jaime L. Benchimol

Flávio C. Edler

Gilberto Hochman 


\section{A Recepção do Darwínísmo no Brasíl}

Heloisa Maria Bertol Domingues, Magali Romero Sá e Thomas Glick Organizadores 
Copyright (c) 2003 dos autores

Todos os direitos desta edição reservados à

FUNDAÇÃO OSWALDO CRUZ / EDITORA

ISBN: 85-7541-032-6

Capa e projeto gráfico

Angelica Mello, Guilherme Ashton e Daniel Pose Vazquez

Ilustração da capa

Zeitschrift für Ethnologie, Berlim, 1872

Editoração eletrônica

Guilherme Ashton

Revisão e copidesque

Janaina S. Silva

Catalogação-na-fonte

Centro de Informação Científica e Tecnológica

Biblioteca Lincoln de Freitas Filho

D671r Domingues, Heloisa Maria Bertol (Org.)

A Recepção do Darwinismo no Brasil. / Organizado por Heloisa Maria Bertol Domingues et al. - Rio de Janeiro: Editora Fiocruz, 2003.

192 p. (Coleção História e Saúde)

1. Evolução 2. Genética I. Sá, Magali Romero II. Glick, Thomas

CDD - 20. ed. -575.0162

2003

EDITORA FIOCRUZ

Av. Brasil, 4036 - $1^{2}$ andar - sala 112 - Manguinhos

21040-361 - Rio de Janeiro - RJ

Tels: (21) 3882-9039 e 3882-9007

Fax: (21) 3882-9006

e-mail: editora@fiocruz.br

http//: www.fiocruz.br

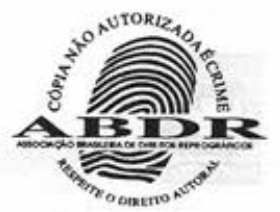




\section{Autores}

\section{Heloisa Maria Bertol Domingues (Organizadora)}

Doutora em história social pela Universidade de São Paulo (USP), pesquisadora associada do Museu de Astronomia e Ciências Afins do Ministério da Ciência e da Tecnologia (Mast/ MCT) e coordenadora do setor de História da Ciência do Mast

\section{Lilia Moritz Shwarcz}

Antropóloga, professora livre-docente no Departamento de Antropologia da Universidade de São Paulo (USP)

\section{Luiz de Castro Faria}

Antropólogo, professor emérito da Universidade Federal do Rio de Janeiro e da Universidade Federal Fluminense. Criador do Programa de Pós-Graduação em Antropologia Social do Museu Nacional (PPGAS/MN)

\section{Magali Romero Sá (Organizadora)}

Doutora em história e filosofia da ciência pela University of Durham, Inglaterra. Pesquisadora associada da Fundação Oswaldo Cruz (Fiocruz) e vice-coordenadora do curso de Pós-Graduação em Ciências da Saúde da Casa de Oswaldo Cruz da Fundação Oswaldo Cruz (COC/Fiocruz)

\section{Nelson Papavero}

Doutor em ciências biológicas pela Universidade de São Paulo (USP), professor visitante do Museu Paraense Emílio Goeldi e professor colaborador do Museu Nacional do Rio de Janeiro

\section{Regina Cândida Ellero Gualtieri}

Doutora em história social pela Universidade de São Paulo (USP). Integrante da equipe de pesquisa e desenvolvimento curricular da Secretaria da Educação do Estado de São Paulo

\section{Thomas Glick (Organizador)}

Professor titular no Departamento de História da Ciência da Universidade de Boston (EUA) e professor colaborador do Centro de Investigação de História de Madri, Espanha 
Sumárío

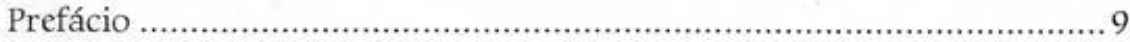

Apresentação ................................................................... 15

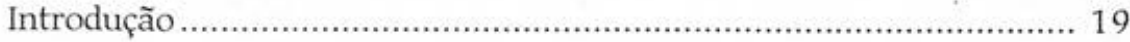

1. Fritz Müller e a Comprovação da Teoria de Darwin

Nelson Papavero

2. O Evolucionismo na Produção Científica do Museu Nacional do Rio de Janeiro (1876-1915)

Regina Cândida Ellero Gualtieri 45

3. Controvérsias Evolucionistas no Brasil do Século XIX

Heloisa Maria Bertol Domingues e Magali Romero Sá

97

4. Virchow e os Sambaquis Brasileiros: um evolucionismo antidarwinista Luiz de Castro Faria .

5. A Fundação Rockefeller e a Emergência da Genética no Brasil (1943-1960)

Thomas Glick

6. O Espetáculo da Miscigenação

Lilia Moritz Schwarcz

7. O Positivismo Brasileiro na Sombra do Darwinismo: o grupo Idéia Nova em Desterro

Thomas Glick 


\section{Prefácío}

Adão não foi criado no dia 23 de outubro de 4004 a.C., por volta das nove horas da manhã, como determinou, após minuciosa leitura das Escrituras, o Vice-Chanceler da Universidade de Cambridge, Dr. John Lightfoot (1602-1675), em fins do século XVII. Segundo ele, o mundo teve sua origem na mesma época. Os cálculos apresentados por Lightfoot eram, de certa forma, mais precisos do que os realizados pelo arcebispo irlandês, James Ussher (1581-1656), que somente fornecia o ano de surgimento do mundo.

Na verdade, a partir da análise de registros geológicos, bem como de estimativas do tempo de processos planetários, a idade da Terra ganhou várias ordens de grandeza desde então. Hoje estima-se que ela tenha uma história de cerca de 4,5 bilhões de anos, tendo passado por diferentes fases em sua trajetória, e a vida, esta estranha manifestação de um sistema ordenado e auto-reprodutivo capaz de se replicar com precisão, parece ter surgido no panorama terrestre há cerca de quatro bilhões.

Mas os cálculos refinados do Arcebispo Ussher e do Vice-Chanceler de Cambridge foram largamente difundidos pela Europa como uma correta cronologia da história do mundo. Somente quando começaram a ser aceitas as evidências fornecidas pelas camadas geológicas e que uma nova interpretação dos fósseis como registros de vida passada pôde ser assimilada que a cronologia biblica começou a ser questionada. Ainda assim, até o início do século XIX, ela foi considerada como um dogma.

Para uma Terra jovem, é possível imaginar uma certa permanência das diferentes formas vivas, criadas no mesmo momento que o mundo e eventualmente extintas por alguma catástrofe seletiva, como o Dilúvio. 
Pode-se, sem dúvida, imaginar todas as formas vivas surgindo praticamente ao mesmo tempo, seguindo, tão-somente, uma hierarquia que leva o homem ao ápice da Criação. Neste cenário, o que existe sempre existiu, embora nem tudo que tenha existido ainda exista, pois o intemperismo pode, perfeitamente, eliminar o que não está de acordo com a vontade do Criador.

Embora esta idéia não tivesse certa dificuldade de ser aceita por parte da igreja, pois cada animal tem uma ligação na cadeia de criação de Deus, que não pode ser quebrada, o paleontologista francês Georges Cuvier (1769-1832) a ela chegou quando afirmou que "l'homme fossile n'existe pas". De fato, Cuvier foi o primeiro a interpretar com sucesso os registros fósseis como registros de vida passada. Sua percepção de que, de alguma forma, o ser morto poderia passar por uma série de transformações químicas até se transformar em um mineral, levou-o a pensar em tempos muito mais longos do que os poucos mais de seis mil anos preditos pelos cálculos realizados a partir da Escritura. Cuvier viu a semelhança entre fósseis e formas vivas e expandiu a proposta de classificação feita por Carl Linneu (1707-1778) para espécies já desaparecidas. Mas o paleontologista não aceitava qualquer idéia evolucionista e foi um opositor de seu colega JeanBaptiste Monet, cavaleiro de Lamarck (1744-1829).

As idéias de Lamarck, muitas baseadas em especulações, têm, entretanto, aspectos importantes. Para ele, as espécies não poderiam ter surgido na Criação e se mantido estáticas desde então, pois se isto ocorresse não sobreviveriam a mudanças do meio. Como conseqüência, ele concluía que as espécies continuamente se alteravam, apesar de muitas vezes manter sua aparência. Estas mudanças poderiam ser diminutas, mas atuariam constantemente e de forma gradual, fazendo com que a vida se adaptasse constantemente às mudanças externas. Contrariamente a seu colega Cuvier, Lamarck defendia a idéia de uma Terra que evolui por contínuas pequenas alterações. De fato, Lamarck foi o primeiro a formular uma teoria da evolução compreensiva e sistemática.

Uma das descobertas de maior importância na geologia foi feita por William Smith (1769-1839) nas primeiras décadas do século XIX: a Terra contém camadas que contam o passado. Ou seja, o estudo destas camadas pode fornecer um cenário de tempos geológicos. Mas, a principal implicação desta descoberta talvez esteja no fato de se admitir que a Terra nem sempre foi como é, que ela possui uma história, que ela sofreu e sofre alterações, que ela, enfim, não se manteve inalterada desde a sua criação. Esta mudança de ótica, associada à idéia de uma Terra muito mais velha do que a prevista 
pela análise restrita das Escrituras, fornece o elemento fundamental para a elaboração de uma teoria sobre a evolução dos seres vivos, pois se o planeta é tão mæsis antigo do que qualquer exercício de raciocínio possa prever, as alterações podem ter acontecido em um ritmo muito lento, imperceptível. Somente a reconstrução da história da vida poderá apontar os caminhos da transformação.

Mas não basta pensar em tempos profundos. É preciso introduzir um mecanismo que permita as alterações e é neste ponto que a contribuição dos naturalistas ingleses Alfred Russel Wallace (1823-1913), Charles Darwin (1809-1882) e Henry Walter Bates (1825-1892) aparece com tamanho destaque. As observações realizadas por estes três naturalistas deram a chave para se pensar em um mecanismo que atue sobre os sistemas vivos e que, de alguma forma, selecione as transformações mais adequadas em um certo momento da história da Terra. Em suas viagens, observando a impressionante diversidade de vida na Floresta Amazônica, na Mata Atlântica, no Sul da Argentina, nas ilhas do Arquipélago de Galápagos ou na Indonésia, estes cientistas, argutos observadores, não poderiam deixar de ver que existe uma estreita relação entre as condições físicas de diferentes hábitats e as espécies que sobrevivem.

Além disso, não passou despercebido para eles o fato de a vida, em suas variadas manifestações, se integrar de forma tão equilibrada com o meio físico; isto levou os naturalistas à conclusão de que uma pressão do meio sobre as espécies poderia ser um mecanismo eficiente para selecionar o que pode sobreviver daquilo que não encontra os recursos necessários para se perpetuar. A percepção de que a luta pela vida exige um grande esforço, mostrava que sobrevive justamente o detentor das melhores condições de adaptação. Este ponto é de fundamental importância: a evolução não leva a uma espécie mais desenvolvida, ela faz com que espécies se adaptem a um mundo mutável não só pela ação de fatores distantes, como pela própria presença de organismos que agem constantemente sobre o meio. Neste momento, fica muito realçada a idéia de que um organismo não possui uma fronteira rígida, não tem um limite físico bem definido, pois está permanentemente trocando informação, energia e matéria com o que se poderia chamar de exterior. Assim, a vida que evolui não é mais uma singularidade especial de um mundo criado há cerca de seis mil anos, mas é parte integrante deste mundo que só é o que é pela presença da vida. Para que tal mecanismo possa funcionar, é indispensável que os tempos envolvidos sejam muito extensos. 
A teoria da evolução pela seleção natural causou um enorme impacto, não só no-meio científico, mas em toda a sociedade ocidental; sua recepção causou polêmica e criou um ambiente polarizado entre aqueles que a defendiam e aqueles que criticavam as possíveis implicações filosóficas e religiosas das idéias. E não é para menos. Para asșimilar a teoria da evolução é preciso entender que a história da vida é muito extensa. Além disso, é preciso reorganizar todo um quadro cultural. Darwin, em sua Autobiografia (2000: 73, 79), comenta as dificuldades que ele próprio sentiu:

Durante dois anos, ${ }^{1}$ fui levado a refletir muito sobre religião. Eu era ortodoxo na época em que estive a bordo do Beagle. Lembro-me de provocar gargalhadas em vários oficiais (embora eles mesmos fossem ortodoxos) por citar a Bíblia como uma autoridade incontestável numa ou noutra questão moral (...) Nesse período, entretanto, eu percebera pouco a pouco que o Velho Testamento, com sua história flagrantemente falsa do mundo - a Torre de Babel, o sinal do arco-íris etc., etc. - e por atribuir a Deus os sentimentos de um tirano e vingativo, não merecia mais confiança do que os livros sagrados dos hindus ou as crenças de qualquer bárbaro (...) Embora não creia que o sentimento religioso tenha sido muito desenvolvido em mim, sentimentos como os que acabei de mencionar levaram-me, no passado, à firme convicção da existência de Deus e da imortalidade da alma. Em meu diário, escrevi que, em meio à grandiosidade de uma floreta brasileira, 'não é possível dar uma idéia adequada dos sentimentos superiores de reverência, admiração e devoção que enchem e elevam a mente' (...) Hoje, entretanto, nem as cenas mais grandiosas trariam à minha mente tais conviç̧ões e sentimentos.

A dificuldade que Darwin e os outros evolucionistas sentiram está diretamente relacionada com a profundidade que uma teoria de evolução por seleção natural traz em seu bojo. Ela teve, e tem, o impacto que, alguns séculos antes, as idéias de Copérnico e Galileu produziram numa sociedade de fundamentos cristãos. Ernst Mayr, em seu livro One Long Argument (1991: 38), sintetiza esta revolução:

Porque levou tanto tempo para a evolução ser seriamente proposta? (...) A razão é que Darwin mudou algumas das crenças básicas de sua época. Quatro delas eram o pilar dos dogmas cristãos:

1 - A crença num mundo constante (...)

2 - A crença num mundo criado (...)

3 - A crença num mundo desenhado por um Criador sábio e bondoso (...)

4 - A crença numa posição única do homem na criação (...). 
Estas razões são suficientes para se compreender por que houve uma forte reação na cultura ocidental para aceitar a teoria da evolução por seleção natural.

Mas há uma outra razão, tão forte quanto esta, para ter havido uma reação negativa à teoria de evolução por seleção natural e ela está ligada justamente à falta de consciência de um tempo profundo. A teoria da evolução, proposta por Darwin e Wallace, tem como pilar o tempo. A evolução por seleção natural atua em milhões de anos, não em poucos milhares de anos. Ela introduz a história no mundo biológico. Não a história das culturas ou a história do homem, mas uma história que tem um tempo muito maior que o tempo da História. E esta história não pode ter a dimensão antropocêntrica, pois, em última análise, a teoria da evolução tira o homem de seu lugar privilegiado e dá a ele um veredicto de desaparecimento. O Homo sapiens desaparecerá, assim como todos as outras formas vivas conhecidas hoje. L'Homo sapiens n'existirá pas, diria Cuvier.

A extrapolação de idéias evolucionistas para o campo social, ou seja, a utilização de idéias importadas do darwinismo para tempos históricos de apenas alguns milhares de anos, fez surgir uma anomalia no pensamento ocidental, o darwinismo social, que, se utilizando da idéia de evolução por seleção natural, aplicou-a a tempos históricos, associando evolução a desenvolvimento e concluindo ser possível hierarquizar as raças, com a conclusão de que o homem branco era superior, sob o aspecto biológico, aos demais.

No Brasil não foi diferente, ainda mais em um país onde mais de $70 \%$ da população era de origem negra. O darwinismo social poderia parecer, para alguns, como uma excelente teoria para justificar determinadas práticas que muito deixaram impressionado o próprio Darwin, quando de sua curta estadia no Brasil. Em seu Diário do Beagle, ele relata um caso que o deixou surpreso:

14 de abril de 1832 - Posso mencionar um caso sem nenhuma importância que, na ocasião, impressionou-me mais vividamente do que qualquer história de crueldade. Estava fazendo uma travessia de balsa em companhia de um negro, que era incrivelmente estúpido. Tentando fazer entender comecei a falar alto, a gesticular e, ao fazer isso, passei a mão perto de seu rosto. Ele, suponho, pensou que eu estava com raiva e ia bater nele, pois, imediatamente, com um olhar amedrontado e os olhos semicerrados, baixou os braços. Nunca me esquecerei do meu sentimento de surpresa, desagrado e vergonha, ao ver um homem grande e forte com medo até mesmo de desviar-se de um golpe dirigido, como pensou, para seu rosto. Esse homem havia sido treinado para suportar uma degradação mais abjeta do que a escravidão do animal mais indefeso. (Darwin, 1996: 21-22) 
Mas é no Brasil que surge a primeira tentativa de se encontrar evidências, no campo da biologia, de um exemplo em que a seleção natural estava atuando e de como idéias mais ou menos abstratas poderiam ser vistas em exemplos reais. E é neste contexto que vão surgir trabalhos, como os de Fritz Müler (1822-1897). É também neste contexto que crescerão as tentativas de se aplicar o darwinismo a uma teoria de raças, criando teorias que tiveram uma curta duração.

O Brasil viveu intensamente o debate em torno do darwinismo e deu a sua contribuição, não sem viver controvérsias que sensibilizaram os meios intelectuais. A 'recepção do darwinismo' no Brasil mostra-nos como foi este processo de assimilação de uma das teorias que mais profundamente alterou e tem alterado o pensamento humano.

Henrique Lins de Barros

Pesquisador titular do Centro Brasileiro de Pesquisas Físicas do Ministério da Ciência e da Tecnologia (CBPF/MCT) e membro honorário da Rede Latino-Americana de Popularização da Ciência (Red-Pop/Unesco)

\section{Notas}

${ }^{1}$ De outubro de 1836 a janeiro de 1839.

\section{Referências Bibliográficas}

DARWIN, C. O Beagle na América do Sul. São Paulo: Paz e Terra, 1996.

DARWIN, C. Autobiografia (1809-1882). Rio de Janeiro: Contraponto, 2000.

MAYR, E. One Long Argument: Charles Darwin and the genesis of modern evolutionary thought. Cambridge: Harvard Universiy Press, 1991. 


\section{Apresentação}

Este livro tem como objetivo suscitar um debate sobre o darwinismo no Brasil, entretanto, está longe de pretender esgotar a questão. A idéia do livro surgiu em função de questões subjacentes às nossas pesquisas sobre a história das ciências naturais no Brasil, no final do século XIX, e começou a tomar forma quando tivemos oportunidade de discuti-las durante o $1^{\circ}$ Colóquio Internacional sobre a Recepção do Darwinismo na América Latina, organizado por Rosaura Ruiz Gutierrez, da Universidade Autônoma do México, em 1997. ${ }^{1}$

Do Darwinismo, pode-se dizer que se tornou um paradigma 'kuhniano', e tem servido a classificar diferentes linhas teóricas que, muitas vezes, são apenas 'evolucionistas'. De certa forma, este livro retrata a contradição que consagrou o conceito ao mesmo tempo que busca avançar no sentido de chamar a atenção para o fato. $\mathrm{O}$ adjetivo darwinista, confundido com evolucionismo, serviu, sob múltiplos aspectos, de argumento ideológico aos mais diversos campos do saber: das ciências naturais ao campo jurídico, ao social etc. A idéia tem sido operada sob diferentes abordagens. A tendência, mais geral, de confundir darwinismo e evolucionismo tem minimizado a oposição a Darwin, levando a classificar opositores da teoria da seleção das espécies de darwinistas, como mostram os trabalhos aqui publicados. Assim, se foi possível abrir e fechar este livro com artigos representativos do evolucionismo 'darwinista', os demais artigos deixam ver o quanto a receptividade à teoria foi motivo de controvérsia no Brasil.

Os trabalhos que apresentamos mostram que, se a idéia da seleção das espécies foi aceita por muitos, foi também uma das mais rejeitadas, polêmicas e incompreendidas. Vê-se, por exemplo, que os trabalhos de 
antropologia e arqueologia realizados em sambaquis ou sobre os índios botocudos foram um meio e também um fórum de debate para a afirmação ou rejeição da teoria da evolução das espécies no país. Essas diferenças teóricas estão aqui discutidas em diferentes trabalhos.

$\mathrm{O}$ artigo de Nelson Papavero foi escolhido como ponto de partida do livro, pois Müller, inegavelmente, foi dos primeiros cientistas, senão o primeiro, a aplicar com êxito a teoria da seleção das espécies, tendo contado com o aval do próprio Darwin. Decerto, se Müller pode ser visto como o homem de Darwin no Brasil, a sua inserção no meio científico brasileiro como um dos maiores estudiosos da teoria da seleção das espécies não foi tão aplaudida quanto deveria ter sido, o que é verificado em outros artigos do livro. Ao mesmo tempo, como se vê no artigo do professor Luiz de Castro Faria, à distância, Virchow, um dos grandes inimigos de Darwin, trabalhou sobre o material brasileiro, enviado a ele por colegas e colaboradores. Virchow teve, além do mais, o apoio do Imperador, que pessoalmente lhe enviava material arqueológico para análise.

A vasta historiografia sobre o tema no Brasil está discutida no artigo de Regina Gualtieri. Embora ela não faça a distinção entre Darwin, Haeckel ou Spencer em relação ao evolucionismo, interpretando-os como 'darwinistas', sua pesquisa acurada nos Archivos do Museu Nacional conclui que, nessa instituição, Darwin foi apenas relativamente aceito. O que não diverge do que afirmamos no artigo seguinte, porém, neste buscamos chamar a atenção para a necessidade de distinguir a teoria de Darwin do 'evolucionismo', mostrando que as ciências naturais tanto quanto as ciências sociais (sociologia e direito) tiveram forte influência da escola francesa que, baseada nos métodos de arqueologia e na craniometria, foi uma das maiores opositoras da teoria da seleção das espécies. A mesma metodologia da escola francesa era adotada por Virchow para trabalhar o material enviado do Brasil.

Os trabalhos aqui apresentados mostram que as relações científicas do Brasil com a França e a Alemanha no período do final do século XIX certamente contribuíram para minimizar a influência de Darwin no país. Ele não foi, no entanto, ignorado e, em Santa Catarina, onde Müller desenvolveu a prova da teoria da seleção das espécies, formou-se um grupo de intelectuais positivistas amigos das idéias de Darwin. Ali se desenvolveram conceitos, em torno do evolucionismo, que contribuíram para as teorias raciais, como mostra o último artigo de Thomas Glick sobre o grupo Idéia Nova. 
O artigo de Lilia Scwarcz enfatiza como aquilo que se convencionou chamar darwinismo social no Brasil contribuiu para difundir conceitos de branqueamento ou para fundar a medicina criminal. Certamente, tal fato é decorrente de teorias, como a antropológica - defendida por João Batista de Lacerda e Rodrigues Peixoto no Museu Nacional - que colocava os 'botocudos' no patamar mais inferior da hierarquia social. A rica mistura de teoria e método, conclui Lilia, converteu o Brasil em uma fonte da teoria racial, nos fins do XIX e início do século XX, e acabou fazendo com que a elite intelectual assumisse uma espécie de 'consciência de atraso'.

$\mathrm{Na}$ verdade, conceitos e preconceitos cruzaram-se por demais, neste conturbado mundo das idéias ditas darwinistas, contribuindo decisivamente para, de um lado, impedir o desenvolvimento dos estudos com base na teoria de Darwin no país e, de outro, forjar a imagem da formação social hierarquizada - colocando índios e negros no patamar mais inferior desta hierarquia -, o que, paradoxalmente, transformou a teoria científica em um libelo ideológico.

Esperamos, com este livro, dar início a um debate que venha a aprofundar entre nós a história dessa teoria que atingiu a tantos campos científicos, orientando-os, desde a segunda metade do século XIX. Os 'preconceitos' gerados por desdobramentos ou por oposições à teoria não conseguiram abalar a solidez dos 'conceitos'.

Somos gratas aos incentivadores deste trabalho, Rosaura Ruiz, Miguel Angel Puig-Samper e, em particular, Thomas Glick, que estimulou a realização, no Brasil, de um trabalho semelhante ao que vinha sendo feito com os estudos históricos do darwinismo na América Latina e, ao mesmo tempo, dividiu conosco a organização deste livro; ao professor Luiz de Castro Faria que, nos seus 90 anos, assentiu em nos dar mais aula; aos que tecnicamente nos apoiaram: Cássio Leite Vieira, na primeira revisão, Luci-Méri Guimarães, no escaneamento das imagens, Francisco dos Santos Lourenço, na revisão da bibliografia, e Gary Cheney no auxílio do trabalho de tradução dos artigos de Thomas Glick.

Heloisa Maria Bertol Domingues e Magali Romero Sá 


\section{Notas}

1 Deste congresso foi publicado o livro El Darwinismo en España e Iberoamérica (1999) e uma versão em inglês: The Reception of Darwinism in the lberian World (2001), com uma versão do artigo "La introducción del darwinismo en Brasil: las controversias de su recepción", aqui publicado.

\section{Referências Bibliográficas}

GLICK, T. F; RUIZ, R. \& PUIG-SAMPER, M. A. (Orgs.) El Darwinismo en España e lberoamérica. Madri: Ediciones Doce Calles, 1999.

GLICK, T. F; RUIZ, R. \& PUIG-SAMPER, M. A. (Eds.) The Reception of Darwinism in the Iberian World, Dordrecht: Kluwer Academic Publishers, 2001. 


\section{Introdução}

Nossa coleção de ensaios sobre o darwinismo no Brasil está estruturada cronologicamente entre a descoberta do mundo natural brasileiro nos anos 30 do século XIX, por Darwin, e a experiência similar de Theodosius Dhobzhansky nos anos 40 e 50 do século XX. O que Darwin viu de imediato foi um mundo orgânico marcado por um alto índice de diversidade de espécies e de fenômenos relacionados, de intensa interdependência ecológica - mesma razão pela qual Dobzhansky se dirigiu ao país um século mais tarde.

Quando Charles Darwin chegou ao Brasil, em maio de 1832, desencadeou um duplo processo: o primeiro, com a publicação do seu diário de pesquisa, em 1839, com o qual chamou a atenção da comunidade científica mundial para a história natural brasileira; o segundo, com a definição do que viria a ser, em grande parte, o programa de pesquisa biológica, como entendido pelos brasileiros e pelos estrangeiros. Nos relatórios de Darwin, fica evidente que ele ficou fortemente impressionado, e mesmo maravilhado, com a paisagem brasileira nos primeiros contatos. Imediatamente, formou uma imagem figurativa da interdependência ecológica, que caracterizou e deu base a sua concepção do mundo orgânico, tornando-se, em A Origem das Espécies (1976), uma metáfora que se fixou indelevelmente nas mentes de seus leitores. Essa imagem, ele deve ter registrado, mentalmente, na Bahia, sua primeira parada e, certamente, ela já havia tomado forma no começo de abril - quando já estava acomodado em um quarto, no bairro de Botafogo, no Rio de Janeiro e realizou uma expedição ao Rio dos Macacos. Nessa ocasião, escreveu:

Pela primeira vez vi uma floresta tropical em toda sua sublime grandeza. Nada mais do que a realidade pode dar uma idéia de quão maravilhosa, quão magnífica, é essa cena. Se eu tivesse que especificar uma coisa qual- 
quer, teria dado a preferência para os hospedeiros das plantas parasíticas.

Sua imagem é exatamente verdadeira, mais subestimada do que exagerada, é luxuriante. Eu nunca experimentei tal intenso prazer. ${ }^{1}$

$\mathrm{Na}$ mesma viagem, observou: "Trepadeiras entrelaçando trepadeiras - trançadas como cabelo - bela lepidoptera - silêncio - hosana". ${ }^{2}$

Dessa forma, o mundo natural do Brasil se imprimiu na mente de Darwin e foi celebrizado na famosa passagem do parágrafo de conclusão de A Origem das Espécies:

É interessante contemplar o emaranhado de uma ribanceira, vestida com muitas plantas de várias espécies, com pássaros cantando nos arbustos, com vários insetos esvoaçando ao redor, e com vermes rastejando na terra úmida, para refletir que essas formas construídas e elaboradas, tão diferentes umas das outras, e dependente de cada uma, de uma maneira tão complexa, têm todas sido produzidas pelas leis atuando ao nosso redor. (Darwin, 1976: 489)

A margem emaranhada, como uma imagem do mundo orgânico altamente interdependente, foi quase que imediatamente apropriada pelos romancistas ingleses da era vitoriana. Romances vitorianos não somente mostravam mundos superpovoados, fervilhantes, com uma grande diversidade de personagens representando os mais variados tipos de personalidade, mas a própria trama acabou tornando-se uma representação social do mundo de Darwin. Como explica George Levine (1988: 18), as narrativas vitorianas, igualmente realistas, enredam histórias complexas e intrincadamente entrelaçam muitas personagens, freqüentemente difíceis de se determinar quais são os principais e quais são os subordinados. Os romances vitorianos multiplot são uma manifestação fictícia das atitudes implícitas na metáfora de emaranhado de Darwin.

As impressões de Dobzhansky, deixadas nas cartas escritas em 1949, foram tematicamente muito similares àquelas de Darwin, o que não é de se estranhar, dado a natureza darwiniana do programa de pesquisa do geneticista russo. Assim, no jornal Cruzeiro do Sul, ele comenta:

A exuberância da vegetação é o que impressiona em primeiro lugar. Isto está lá, é claro, para qualquer um ver. De um barco no rio se pode ver somente paredes verdes, sólidas, impenetráveis, subindo de cada lado a grandes alturas. (...) O ambiente orgânico alcança aqui uma complexidade inacreditável, e oferece numerosos e altamente elaborados desafios. Milhares de espécies de plantas e animais estão misteriosamente interrelacionados. ${ }^{3}$ 
Quando Dobzhansky chegou ao Brasil, em 1941, seu programa de estudo de genética de população na natureza (ao invés do laboratório) encaixou-se na tradição do Brasil como um centro de estudos do campo darwinista - no século XIX, Wallace, Bates e Müller tinham todos estudado mimetismo no Brasil como um tópico evolucionista clássico. Mais tarde, em seu famoso artigo sintetizando o que era conhecido sobre diversidade de espécies no ambiente tropical (um artigo que teve um papel fundamental na ecologia tropical), Dobzhansky descreveu seu próprio experimento em Belém, onde três espécies foram contadas em um hectare de terra, permitindo determinar a dinâmica da associação de plantas - uma espécie de réplica, em um palco tropical do famoso weed garden, das observações de Darwin, apesar de Dobzhansky não ter feito explicitamente a conexão. ${ }^{4}$

\section{Darwinismo nas Bibliotecas Brasileiras}

Muitas informações sugestivas sobre a recepção de Darwin no Brasil podem ser detectadas nos catálogos das bibliotecas. ${ }^{5}$ Ao olhar, por exemplo, o museu que foi dirigido por von Ihering - Museu de Zoologia de São Paulo - isto fica claro. Apesar de von Ihering não ter sido um darwinista, era muito bem informado sobre as pesquisas que lhe eram contemporâneas. ${ }^{6}$ A biblioteca do museu contém os cinco volumes da série da "Zoology of the Voyage of the Beagle", os volumes sobre cirripedes, os quais deveriam ter sido de interesse de von Ihering, com seu clássico treinamento morfológico, e uma tradução alemã da Origem (Stuttgart, 1876). Os principais trabalhos de Haeckel também estão lá, assim como o de Carl Gegenbaur, "Verleichende Anatomie" (Leipzig, 1870, com uma etiqueta marcada Coleção von Ihering). Esta presença é emblemática porque Gegenbaur era um anatomista comparado puramente darwiniano.

O Museu Nacional no Rio de Janeiro tem a melhor coleção de darwinistas do século XIX, dentre todas as instituições da América Latina. A Instituição possui trabalhos de Haeckel em alemão, francês e inglês, e uma coleção virtualmente completa de livros de seu autor. O Museu tem também as obras completas de Thomas Huxley, principalmente em inglês, mas algumas traduções francesas. Todos os trabalhos de Darwin são encontrados em inglês e em francês (em geral as edições francesas são mais antigas do que as inglesas). Existem trabalhos geológicos também em alemão, refletindo a importância dos geólogos, no século XIX, no Brasil.? 
De A Origem, existe a sexta edição inglesa (London), de 1888, três edições francesas (a vil versão lamarckiana de Royer, de 1862, e duas versões publicadas por Reinwald em 1866 e 1887) e uma em alemão (Stuttgart), de 1872.

Considerando outras instituições, a biblioteca da Escola Politécnica tinha cópias do livro de Darwin, Descent and Expression of Emotions in Man and Animals, todas em francês. ${ }^{8} \mathrm{O}$ Instituto Oswaldo Cruz tem muitos dos trabalhos de Darwin em edições publicadas em inglês por Appleton em 1890. Isto não é surpresa porque Oswaldo Cruz queria que seu instituto, fundado em 1900, desempenhasse uma nova espécie de 'ciência' e o trabalho de Darwin era a base da biologia. As edições germânicas de Stuttgart de A Origem e Descendência estão presentes, como também a primeira edição de Cirripédios e Radiolários, de Haeckel (1862-1888). Fazendo parte do programa de Oswaldo Cruz, encontra-se Les Problèmes de la Biologie, de Huxley (Paris, Ballière), publicado em 1892.

O Jardim Botânico também parece ser um baluarte darwinista, tomando por base sua biblioteca. Todos os volumes botânicos de Darwin estão representados, em inglês e em francês, bem como o A Origem, em ambos os idiomas, e Descendência em inglês. Volumes de Haeckel e Huxley também estão incluídos.

As Escolas de Direito foram também importantes arenas da discussão da teoria darwinista. Na Faculdade de Direito de São Paulo, existem as edições francesas do Descendent of Man (1873-1874) e da Expression of the Emotions (1874). Mas, o darwinismo chegou aos advogados principalmente através de Spencer, e esta mesma biblioteca tem vinte títulos de Spencer em francês, dois em italiano e dois em português. Entre os títulos darwinistas, a biblioteca da Escola de Direito tem também trabalhos de Huxley e Haeckel em francês (antes de 1900) e a importante série dos trabalhos de Haeckel traduzida para português de Portugal entre 19081919. ${ }^{9}$ Na Faculdade de Direito de Porto Alegre, existem também trabalhos de Spencer em francês e português, o Descendência e A Origem, de Darwin, ambos em francês, e trabalhos de Haeckel também em francês.

\section{A Polêmica de Darwin}

Em todo o mundo latino a recepção do darwinismo causou um afiado debate entre católicos - em particular a alta hierarquia da igreja - e darwinistas, com tendência fortemente anticlerical. Se levarmos em 
consideração a Espanha, como modelo de polarização extrema, não existia - levando-se em consideração quase a totalidade - nenhum darwinista que fosse religioso e nenhum político conservador que fosse darwinista, sendo que a única exceção significativa era de um grupo de clérigos católicos progressistas. Com poucas exceções, o governo central controlava a maioria das instituições públicas relevantes (universidades, museus), de uma forma tal que ficava difícil para seus empregados serem abertamente darwinistas. Não existia nenhuma possibilidade de haver um discurso civil entre direita e esquerda sobre o tema. ${ }^{10}$

Três fatores separados mitigavam a expressão, tão afiada em polarização ideológica, sobre o darwinismo no Brasil. O primeiro era que o Imperador não era de todo contrário a Darwin; ${ }^{11}$ o segundo era que os elementos da elite católica foram cooptados em seus pontos de vista pelo evolucionismo poligenista com uma base cientificamente legitimada para a manutenção da supremacia branca. Com essa visão, a elite, mesmo se católica, tinha alguma coisa para ganhar aceitando o programa poligenista da evolução humana. Apesar de incomum, outras elites católicas estavam também atentas a sacrificar seus princípios religiosos se existisse uma boa razão para tal. Vaqueiros uruguaios que favoreceram a seleção ao invés do cruzamento, por exemplo, não tiveram dificuldade de citar Darwin com aprovação. ${ }^{12} \mathrm{O}$ terceiro fator, relevante para nosso argumento, é que, no Brasil, havia simpatizantes do darwinismo no controle das principais instituições: museus de ciências (Ladislau Netto, no Museu Nacional, era simpático ao darwinismo e Emilio Goeldi, no Museu do Pará, era um haeckliano; já von Ihering, em São Paulo, era um evolucionista, mas não um darwinista); em importantes faculdades, como a de Medicina, na Bahia, e a de Direito, no Recife, discutia-se a teoria. Por todas essas razões a recepção de Darwin no Brasil pareceu menos problemática do que na maioria dos outros países católicos.

O problema racial estimulou o discurso evolucionista e levou a um movimento para classificar as raças cientificamente. Neste discurso, ambos, sambaquis e botocudos, tornaram-se 'tropo' darwinistas. Sambaquis são montes de conchas (middens) considerados restos de antigos assentamentos humanos. Hoje, eles são principalmente valorizados pelos arqueólogos como pistas para o conhecimento da dieta humana, mas, no século XIX, eram considerados registros do passado dos índios. A estratégia das pesquisas nos sambaquis (principalmente germânicas, mas algumas brasileiras) era associar sambaquis ao crânio 'primitivo', com o objetivo de demonstrar as deficiências biológicas dos índios. 
O poligenismo brasileiro era a forma darwinista de 'racismo científico' (entre aspas porque Darwin era um monogenista). Poligenistas pré-Darwin eram apoiados por aqueles que achavam ofensivo que judeus pudessem ter sido os ancestrais de toda a raça humana. Os primeiros poligenistas norteamericanos, como o anatomista Samuel George Morton, eram celebrados pelos darwinistas sociais brasileiros, como Euclides da Cunha, que admirava o trabalho pró-escravos - pro-slavery - dos estudantes de Morton, George R. Gliddon e Josiah Clark Nott. O que atraía Cunha era a idéia da origem diferenciada das raças, que fazia possível uma América autônoma, berço da espécie humana - idéia adotada pelo paleontólogo argentino Florentino Ameghino. $\mathrm{O}$ antropólogo inglês James Cowles Prichard afirmava que Adão era negro e que toda a espécie humana tinha se tornado progressivamente branca através de um processo semelhante - a seleção sexual -, o que foi de imediato considerado fonte de classificação evolucionista da raça humana, de preto para branco, de superior para inferior. ${ }^{13} \mathrm{O}$ aparentemente alto nível de miscigenação no Brasil converteu o país em um 'grande laboratório racial', cujos técnicos eram preeminentemente cientistas germânicos de posse dos últimos métodos em craniometria. Esta rica mistura de teoria e método converteu o Brasil em uma fonte fecunda da teoria racial nos fins do XIX e início do século XX.

\section{Imperialismo Científico}

O imperialismo científico teve uma variedade de formas no século XIX: expedições européias; o estabelecimento de instituições estrangeiras pelos poderes imperiais; ou simplesmente uma representação - com o suporte ou não do governo -, posto ocupado por cientistas estrangeiros em um dado país. É esse último fenômeno que nos interessa aqui: Fritz Müller passou toda a sua vida profissional no Brasil, como fez Hermann von Ihering. Podem suas pesquisas serem retratadas como simplesmente as de representantes estrangeiros da ciência germânica ou elas participaram da ciência brasileira? Uma maneira para avaliar este assunto é saber onde a pesquisa em questão foi publicada. Müller, igualmente fluente em alemão, português e inglês, certamente publicou o suficiente em periódicos brasileiros para ter impacto nesta comunidade científica. Sua relação com naturalistas brasileiros, contudo, tem ainda de ser trabalhada. Decerto, Müller poderia ser visto como o homem de Darwin no Brasil, em igual ou maior medida, do que um homem 
germânico no Brasil. O correspondente germânico de Virchow no Brasil, ao contrário, parecia principalmente ter-se reportado à Europa, ao invés de participar da ciência brasileira, bem como a internacional, e com Goeldi não há nenhuma dúvida: por todos os propósitos práticos, ele era rígido em suas conexões com a ciência européia. Notícias de pesquisas recentes o alcançavam mais tarde, enquanto Müller aparentava não ter tido nenhuma dificuldade em manter relações com o front da pesquisa.

Temos feito distinção entre recepção ativa e passiva das idéias científicas. ${ }^{14} \mathrm{Na}$ recepção passiva, um grupo de uma disciplina dada irá limitar-se a comentar ou disseminar uma nova idéia científica. O modo ativo, por contraste, envolverá a participação em um novo paradigma. Vendo sob essa perspectiva, Müller era um participante ativo e afiado de um novo paradigma evolucionista. Mas ele participou como um brasileiro ou como um alemão? A distinção é importante porque Müller, embora tenha trabalhado na periferia, era um verdadeiro cientista da 'metrópole'. ${ }^{15}$ Netto, com a pesquisa sobre adaptação das plantas trepadeiras, é exemplo de um 'ativo' participante brasileiro em uma nova ciência darwinista. Tal fato é significante, porque sua habilidade para alcançar o front da pesquisa científica reflete a relativa força de sua base institucional. E aí está outra interessante distinção: Fritz Müller tinha um número de bases institucionais no Brasil, mas sua participação no front de pesquisa darwinista não era predicado para dar suporte a qualquer uma delas. ${ }^{16}$ Sem a infra-estrutura do Museu Nacional era duvidoso que os esforços de Netto fossem registrados. Então, deve-se concluir que os pré-requisitos individuais dos cientistas, no que diz respeito à habilidade de participar no front de pesquisa, diferem em consonância com um numeroso contingente de fatores sociais e institucionais, incluindo a habilidade de se conectar efetivamente com redes científicas, requisito internacional de comunicação. A recepção passiva e mesmo a retórica do darwinismo com nenhum efeito sobre a pesquisa biológica nacional era muito mais comum em países ibéricos nos fins do século XIX: Espanha é um caso a apontar, como foram virtualmente todos os países da América espanhola, com exceção da Argentina, México e Cuba. Brasil, dessa forma, ocupa a camada intermediária, primeiro por causa da relativa força dos seus museus de história natural e segundo por causa de sua incomparável facilidade de acesso à ciência germânica. 


\section{Notas}

1 Darwin para Henslow: 18 de maio de 1832. Ver Darwin (1985: 237).

2 Ver Browne (1995: 213).

3 Glass (1980: 42, 44).

4 Dobzhansky (1950: 212-213).

5 Estão considerados aqui somente os títulos pré 1900.

6 O evolucionismo de von thering estava relacionado à perspectiva embriológica de von Baer. Ihering (1904: 3317), em seu trabalho sobre a biologia dos tiranídeos, dizia: "Essas diferenças não podem ser explicadas pela então chamada lei da seleção natural, mas têm relações com as afinidades genéticas e os movimentos internos, os quais, independentemente da suposta seleção natural, determinam a variação individual bem como o desenvolvimento filogenético dos organismos". Esta visão é consistente com algumas noções neo-lamarckistas contemporâneas, mas está originada na tradição evolucionista da morfologia embriológica germânica. Sobre evolucionismo teleomecanicista ver Montgomery (1989).

7 Como por exemplo: Darwin, Geologische Beobachtungen uber Sud-America (Stuttgart, 1878); Kleinere Geologisch Abhandlungen (Stuttgart, 1878). Sobre a publicação em Stuttgart da obra completa de Darwin na Alemanha, ver Montgomery (1989).

8 Ver Turazzi (1989).

9. Haeckel $(1908,1910,1919)$.

v Ver Glick $(1993,1994)$.

" D. Pedro disse que: "costumo recomendar muitas vezes aos meus jovens patrícios a conveniência de lerem as obras de Darwin porque sou adepto da verdade; e quanto mais leio me convenço de que toda a verdade é uma só, e de que todas as ciências se encontram nesse ponto - o da Verdade". (Lyra, 1977).

r Ver Glick (1997).

B Ver a interessante discussão do determinismo pré-darwinista e sua metamorfose pós-darwinista no quarto capítulo de Harris (1968).

4 Ver Glick (1987).

v Para uma crítica do modelo centro/periferia e uma discussão de sua limitação ver Chambers (1993).

b Müller financiou sua pesquisa de diferentes maneiras: como professor de matemáti$\mathrm{ca}$, como naturalista viajante etc. Sua pesquisa requeria pouca infraestrutura, e ele se comunicava diretamente com os biologistas europeus. 


\section{Referências Bibliográficas}

BROWNE, J. Charles Darwin: voyaging. Nova Iorque: Alfred A. Knopf., 1995.

CHAMBERS, D. W. Locality and science: myths of centre and periphery. In: LAFUENTE, A.; ELENA, A. \& ORTEGA, M. L. (Orgs.) Mundialización de la Ciencia y Cultura Nacional. Madri: Doce Calles, 1993.

DARWIN, C. On the Origin of Species. Cambridge/Massachusetts: Harvard University Press, 1976. (A facsimile of the first edition, 1859)

DARWIN, C. The Correspondence of Charles Darwin: 1821-1836. Cambridge: Cambridge University Press, 1985. v.1.

DOBZHANSKY, T. Evolution in the Tropics. American Scientist, 38: 209-221, 1950.

GLASS, B. (Ed.) The Roving Naturalist: travel letters of Theodosius Dobzhansky. Philadelphia: American Philosophical Society, 1980.

GLICK, T. La transferencia de las revoluciones científicas através de las fronteras culturales. Ciencia y Desarrollo, 12(72): 77-89, 1987.

GLICK, T. Ciencia, política y discurso civil en la España de Alfonso XIII. Espacio, Tiempo y Forma, 6: 81-98, 1993. (Série V, Historia Contemporánea)

GLICK, T. Ciencia, política y discurso civil en la España de Alfonso XIII. In: GORTÁZAR, G. (Org.) Nación y Estado en la España Liberal. Madri: Noesis, 1994.

GLICK, T. Darwinismo y ganaderia: la polémica entre selección y cruzamiento en la América Latina. In: ARBOLEDA, L. C. \& OSORIO, C. (Orgs.) Nacionalismo e Internacionalismo en la Historia de las Ciencias y la Tecnologia en la América Latina. Cali: Ed. Universidad de Cáli, 1997.

HAECKEL, E. H. P. A. Religião e Evolução. Porto: Lello \& Irmão, 1908.

HAECKEL, E. H. P. A. Maravilhas da Vida. Porto: Lello \& Irmão, 1910.

HAECKEL, E. H. P. A. O Monismo. 2.ed. Porto: Chardon, 1919.

HARRIS, M. The Rise of Anthropological Theory. Nova Iorque: Crowell, 1968.

IHERING, H. von. The biology of the tyrannidae with respect to the their systematic arrangement. The Auk, 21: 3313-3322, 1904.

LEVINE, G. Darwin and the Novelists: patterns of science in victorian fiction. Cambridge/ Massachusetts: Harvard University Press, 1988.

LYRA, H. História de Dom Pedro II, 1825-1891: fastígio 1870-1880, 1977. São Paulo: Universidade de São Paulo.

MONTGOMERY, W. M. Germany. In: GLICK, T. (Ed.) The Comparative Reception of Darwinism. 2.ed. Chicago: University of Chicago Press, 1989.

TURAZZI, M. I. A Euforia do Progresso e a Imposição da Ordem. São Paulo: Marco Zero, 1989. 


\section{Fritz Müller e a comprovação da Teoria de Darwín}

Nelson Papavero

\section{Introdução}

Johann Friedrich Theodor Müller, mais conhecido como Fritz Müller, nasceu em Windischolzhausen, perto de Erfurt, Alemanha, em 31 de março de 1822; era filho do pastor protestante Johannes Friedrich Müller e neto do químico J. Bartholomäus Thomsdorff.

Müller aprendeu as primeiras letras na aldeia de Muhlberg e em 1835 ingressou no ginásio de Erfurt, junto com seu irmão Hermann. Devido à sua vocação para a matemática e as ciências naturais, ingressou nas Universidades de Berlim e Greifswald. Na primeira, defendeu, em 1844, a tese De Hirudinibus Circa Berolinum Hucusque Observatis. ${ }^{1}$ Obteve assim o grau de doutor em Filosofia. Seus professores foram os zoólogos Lichtenstein e Erichson, os botânicos Kunth e Hornsbuch, e o fisiólogo Johannes Müller. De 1845 a 1848, Müller freqüentou o curso de medicina em Greifswald para poder ocupar o posto de médico de bordo de algum navio que se dirigisse rumo a países estrangeiros.

Com a revolução de 1848 e a situação subseqüente da Alemanha, Müller, sua mulher, sua filha e seu irmão, August, com sua respectiva mulher, decidiram emigrar para o Brasil. Em 20 de maio de 1852, deixaram Hamburgo no navio Florentina. Na noite do dia 18 de junho, desembarcavam na cidade de São Francisco, litoral da então província de Santa Catarina. Vieram ao Brasil para se estabelecer na colônia fundada por Hermann Otto Blumenau (atual cidade de Blumenau). Ali chegaram em um domingo, 22 de agosto de 1852. 
Fritz Müller começou a trabalhar como colono, dedicando-se à agricultura e à construção de sua própria casa. De 1856 a 1867, ensinou matemática no Liceu Provincial na cidade de Desterro, Ilha de Santa Catarina, atual Florianópolis. Em seguida, trabalhou como naturalista para o governo da província até 1891, com um intervalo entre 1884 e 1888; foi contratado como naturalista-viajante do Museu Nacional do Rio de Janeiro, cargo do qual foi destituído injustamente depois da proclamação da República no Brasil em 1889.

Pesquisador incansável, no meio de muitos afazeres, sempre encontrava tempo para fazer investigações e observações impressionantes sobre história natural. Sua produção foi imensa: de 1844 até 1899 publicou 248 trabalhos em vários países do mundo.

Em 24 de março de 1894, morreu sua mulher, Karoline Tollner, com quem havia casado em 27 de abril de 1852, pouco antes de vir para o Brasil. Tiveram dez filhos, nove mulheres e somente um homem - este faleceu no mesmo dia em que nasceu.

Em 1868, a Universidade de Bonn outorgou-lhe o título de doutor Honoris Causa e no seu diploma constava a seguinte inscrição:

qui cum scientiam zoologicam et botanicam multis iisdemque gravissimis observationibus amplificavit tum disquisitionibus imprimis de evolutione crustaceorum in Brasilia litore institutis doctrinae Darwiniae nova gravissima que adjumenta attulit. ${ }^{2}$

Em 1874, foi nomeado membro correspondente da Sociedad Zoológica Argentina e doutor Honoris Causa da Universidade de Tübingen; em 1884, membro correspondente da Sociedad Nacional de Ciencias de Buenos Aires e membro honorário da Entomological Society de Londres.

Fritz Müller faleceu no dia 21 de maio de 1897, em Blumenau, Santa Catarina. Hoje, sua casa é um museu e nela pode-se ver o modestíssimo microscópio com o qual fez tantas extraordinárias observações. Um monumento foi erguido na cidade em sua gloriosa memória.

\section{A Publicação de Für Darwin}

Fritz Müller leu o livro de Darwin sobre a origem das espécies na tradução alemã de Bronn, de 1860. Decidiu colocar à prova as idéias do naturalista inglês, aplicando-as a um certo grupo de animais. Como escreveu no primeiro capítulo de seu clássico livro Für Darwin (1864: 1-2): 
A tentativa de estabelecer uma árvore genealógica, seja para as familias de uma classe, seja para os gêneros de uma grande familia, ou para as espécies de um rico gênero, e de esboçar um quadro tão completo e claro quanto seja possível dos ancestrais comuns e distintos dos grupos mais ou menos relacionados, poderia oferecer-nos três resultados diferentes.

Poderia suceder, 1 - Que as suposições de Darwin, aplicadas desta maneira, nos levassem a conclusões irreconciliáveis e contraditórias, a partir das quais poder-se-ia inferir sua falsidade (...).

Poderia suceder, 2 - Que a tentativa fosse bem-sucedida em maior ou menor grau. Se fosse possível, com as bases e o apoio da doutrina darwinista, mostrar de que maneira os diversos grupos menores e maiores se separaram uns dos outros, desde a forma fundamental comum, e de que modo adquiriram as particularidades que os caracterizam atualmente, e quais as transformações que sofreram no decorrer do tempo; se fosse possível apresentar uma árvore genealógica, a história primordial, do grupo animal considerado, livre de contradições internas, então essa apresentação, quanto mais incluísse as espécies conhecidas e mais profundamente pudesse descer aos pormenores da estrutura, tanto mais deveria trazer em si mesma a garantia da verdade e tanto mais convincentemente ofereceria a prova de que a base sobre a qual foi edificada não é areia movediça, mas sim algo mais que um mero 'sonho brilhante'.

É verdade que, 3 - Também é possível, o que de início não poderia deixar de parecer o caso mais provável, que a iniciativa fracassasse pelas dificuldades contrárias, sem decidir a questão nem a favor nem contra, de uma maneira irreconciliavelmente concludente. Porém, ainda que somente fosse possível chegar a um juízo independente, moderadamente certo, sobre uma matéria que afeta tão profundamente as mais altas questões, isto não poderia deixar de ser considerado uma grande aquisição.

O grupo escolhido Müller foi o dos crustáceos, não somente por ser abundante e estar à sua disposição no litoral da Ilha de Santa Catarina, onde trabalhava como professor, mas também porque, para a época, era um grupo razoavelmente conhecido do ponto de vista taxonômico. Ademais, as espécies podiam ser criadas experimentalmente e apresentavam uma grande variedade de biologias. Müller realizou então uma série extraordinária de observações e experimentos, descobrindo muitas novidades sobre o desenvolvimento embrionário de vários grupos. O resultado foi, conforme declarou no capítulo II do seu Für Darwin (1864: 5), que:

Durante o período crucial da dúvida, que não foi curto, em que o fiel da balança oscilava diante de mim em perfeita incerteza entre os prós e os contras, e quando todo e qualquer fato conducente a uma pronta decisão houvera sido bem-vindo, nunca tive o menor problema com quaisquer 
contradições surgidas entre as conseqüências trazidas para a classe dos crustáceos pela doutrina de Darwin. Pois nunca as encontrei, nem então, nem depois. Aquelas que acreditava haver encontrado dissiparam-se com uma consideração mais profunda; ou converteram-se em sustentáculos da doutrina darwinista.

Für Darwin foi publicado em Leipzig, por Wilhelm Engelmann, em 1864, com 91 páginas de texto e uma densidade incrível de fatos, em sua maioria novos, e idéias. Müller, pode-se dizer tranqüilamente, foi o primeiro a criar uma filogenia séria, com base no estudo exaustivo de material vivo, ao contrário das especulações meramente teóricas e fantasiosas, como as feitas por Haeckel.

Darwin leu essa obra em 1865 e escreveu a Fritz Müller em 10 de agosto desse mesmo ano, inaugurando uma correspondência que duraria até a morte do primeiro, ocorrida em 1882. Por recomendação de Darwin, W. S. Dallas fez uma tradução do livro para o inglês, publicada em 1869 , com o título (sugerido por Sir Charles Lyell) Facts and Arguments for Darwin. A obra já havia sido resumida e criticada por Spence Bate no primeiro volume do The Record of Zoological Literature, editado em Londres por Günther, em 1864. Em 1865, apareceu resumida nos Annals do and Magazine of Natural History, com o título The darwinian hypothesis supported by observations on crustacea.

Traduções posteriores foram efetuadas na França (por Debray, em 1893, Bulletin Scientifique du Departement du Nord) e na Suíça (resumo, 1865, Bibliothèque universelle et Revue Suisse - Archives des Sciences physiques et naturelles). A tradução brasileira saiu em 1907-1908, na revista Kosmos, assinada por "Cryptus" (pseudônimo do zoólogo Alípio de Miranda Ribeiro); outra tradução em português (com vários erros) foi publicada por Nomura em 1990. Uma tradução para o espanhol foi dada por Papavero \& Llorente-Bousquets (1996).

A biografia, a correspondência e todos os trabalhos de Fritz Müller foram publicados em cinco volumes editados por seu sobrinho Alfred Möller entre 1915 e 1921.

\section{Evidência a Favor do Mecanismo Darwinista de Especiação}

Vejamos inicialmente qual era a idéia de Darwin sobre a diferenciação de uma espécie ancestral em populações e espécies descendentes (Papavero \& Llorente-Bousquets, 1994, 1996). 
Suponhamos que uma espécie $\mathrm{A}$, desde há muito tempo adaptada a um certo lugar, ocupe primitivamente uma área $S_{1}$ (Figura 1). Essa espécie, por alguma alteração do ambiente, entraria em dispersão e passaria a ocupar uma área muito mais ampla, $\mathrm{S}_{2}$.

Figura 1 - Esquema ilustrativo da idéia de Darwin da diferenciação de uma população ancestral em populações descendentes, com posterior competição entre estas e a sobrevivência apenas das mais aptas
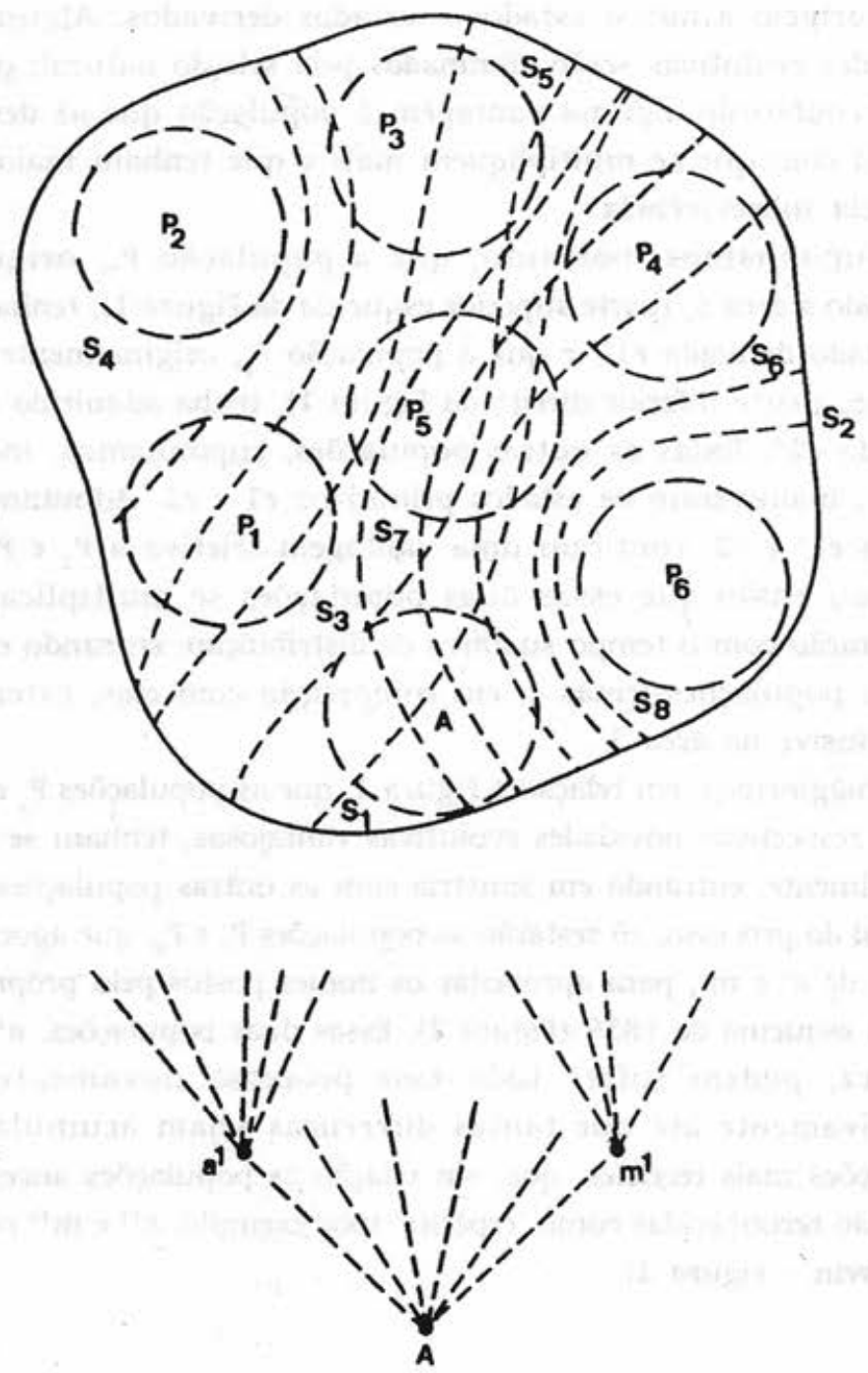
Imaginemos que essa mesma espécie, entre outros caracteres (e seus estados), possua os estados e1 de um caráter e e2 de outro. Darwin postulou que essa população ocupante da área $S_{2}$ dividir-se-ia em populações secundárias - em nosso exemplo, as populações $\mathrm{P}_{1}, \mathrm{P}_{2}, \mathrm{P}_{3}, \mathrm{P}_{4}, \mathrm{P}_{5}$ e $\mathrm{P}_{6}$, ocupando, respectivamente, as áreas $\mathrm{S}_{3}, \mathrm{~S}_{4}, \mathrm{~S}_{5}, \mathrm{~S}_{6}, \mathrm{~S}_{7}$ e $\mathrm{S}_{8}$. Uma dessas populações continuaria ocupando a área ancestral $S_{1}$.

Como as populações que não mais estão na área original $S_{1}$ ficarão submetidas a distintos ambientes; por pressão desses ambientes (distintos do ambiente $S_{1}$ ), alguns de seus caracteres se transformarão e darão origem a novos estados - estados derivados. Algumas dessas novidades evolutivas serão eliminadas pela seleção natural; outras, por acaso, conferirão alguma vantagem à população que as desenvolveu, fazendo com que se multipliquem mais e que tenham maior êxito na luta pela sobrevivência.

Suponhamos, portanto, que a população $\mathrm{P}_{2}$, originalmente ocupando a área $\mathrm{S}_{4}$ (parte superior esquerda da Figura 1), tenha adquirido um estado derivado $\mathrm{e} 1$ ', e que a população $\mathrm{P}_{6}$, originalmente ocupando a área $S_{8}$ (parte inferior direita da Figura 1), tenha adquirido um estado derivado e 2 '. Todas as outras populações, suponhamos, inclusive na área $\mathrm{S}_{1}$, mantiveram os estados primitivos e1 e e2. Admitamos que os estados e1' e e2' confiram uma vantagem seletiva a $P_{2}$ e $P_{6}$. Darwin postulou então que essas duas populações se multiplicarão mais, aumentarão com o tempo sua área de distribuição, entrando em contato com as populações-irmãs e, em competição com elas, exterminá-lasão, inclusive na área $\mathrm{S}_{1}$.

Imaginemos, em relação à Figura 1, que as populações $\mathrm{P}_{2}$ e $\mathrm{P}_{6}$, graças a suas respectivas novidades evolutivas vantajosas, tenham se dispersado gradualmente, entrando em simetria com as outras populações restantes. No final do processo, só restarão as populações $\mathrm{P}_{2}$ e $\mathrm{P}_{6^{\prime}}$ que agora podemos batizar de $\mathrm{a}^{1}$ e $\mathrm{m}^{1}$, para aproveitar os nomes postos pelo próprio Darwin em seu esquema de 1859 (Figura 2). Essas duas populações, $\mathrm{a}^{1}$ e $\mathrm{m}^{1}$, por sua vez, podem sofrer todo esse processo novamente e assim sucessivamente até que tantas diferenças sejam acumuladas pelas populações mais recentes, que, em relação às populações ancestrais, $a^{1} e$ $\mathrm{m}^{1}$, serão reconhecidas como 'espécies' (por exemplo, $\mathrm{a}^{14}$ e $\mathrm{m}^{14}$ no esquema de Darwin - Figura 2). 
Figura 2 - Digrama de Darwin sobre a divergência dos táxons

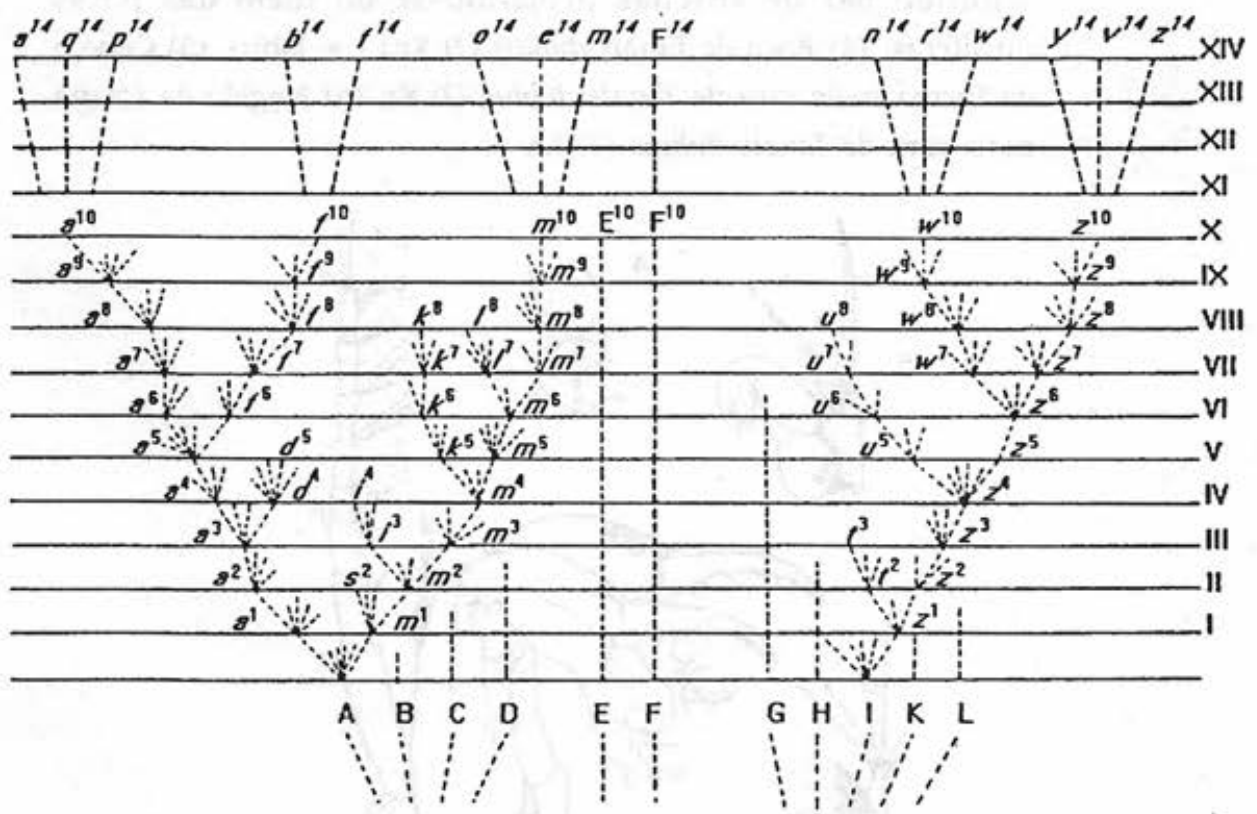

Fonte: Darwin, 1859.

Tratava-se de um modelo puramente teórico. Müller, pela primeira vez, em Für Darwin, empregou dados concretos que (aparentemente) ilustravam o esquema de Darwin.

Um primeiro caso referiu-se a uma espécie de Tanais (Figura 3). Os machos dessa espécie,

próximos à muda que antecede a maturidade sexual, assemelham-se às fêmeas, e nessa ocasião sofrem importantes metamorfoses (...). Surgem então sob duas formas diferentes. Alguns adquirem pinças poderosas, macrodáctilas e muito móveis, e, em lugar do filamento olfativo único da fêmea, possuem de 12 a 17 desses órgãos agrupados em conjuntos de dois ou três em cada articulação do flagelo. Os outros mantêm a forma espessa e curta das fêmeas, mas, em compensação, suas antenas são providas de um número muitíssimo maior de filamentos olfativos, reunidos em grupos de cinco a sete. (Müller, 1864: 14) 
Figura 3 - Ilustrações de Fritz Müller dos caracteres de Tanais. (3) Cabeça da forma comum de Tanais dubius (?) $\mathrm{Kr}$. As cerdas terminais do segundo par de antenas projetam-se do meio das patas quelíferas. (4) Boca de Tanais dubius (?) Kr.; l = labro. (5) Cabeça da forma mais rara de Tanais dubius (?) $\mathrm{Kr}$. (6) Flagelo da forma mais rara de Tanais dubius (?) $\mathrm{Kr}$.

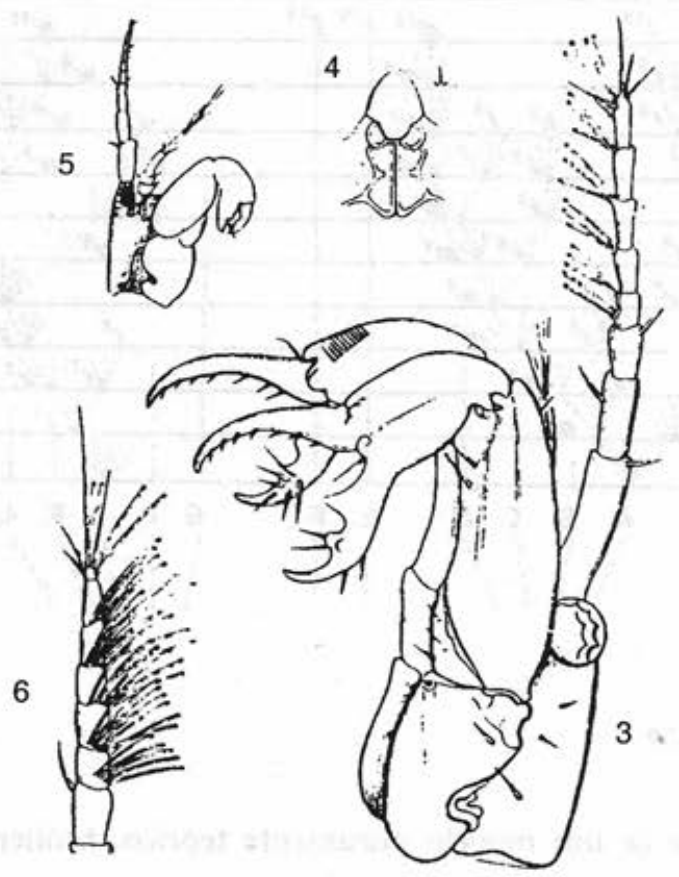

Fonte: Müller, 1864.

Para Müller, tratava-se de uma só espécie com dimorfismo sexual masculino:

Seria natural pensar na existência de duas espécies diferentes, com fêmeas muito semelhantes e machos diferentes, vivendo juntas, ou que os machos, em vez de surgir sob duas formas bem definidas, fossem variações dentro de limites muito amplos. Não se pode admitir nem um nem outro caso. Nosso Tanais vive dentro de algas densamente entrelaçadas, que formam um revestimento de aproximadamente uma polegada de espessura sobre as rochas vizinhas das praias. Se se colocar um fragmento de feltro verde dentro de um vidro com água marinha limpa, as paredes do vaso imediata- 
mente se vêem cobertas por centenas, senão por milhares, desse pequeno isópode, roliço e esbranquiçado. Dessa maneira examinei milhares deles com uma simples lente, assim como muitas centenas ao microscópio, sem encontrar diferença alguma entre as fêmeas ou qualquer outra forma intermediária entre as duas formas de machos. (Müller, 1864: 15)

A seleção darwiniana, aos olhos de Fritz Müller, explicava claramente o fato. Iniciada a variação nos machos, somente ficaram, depois do desaparecimento de outros menos aptos, dois grupos, os olfativos e os apreensores. Entre os dois grupos, seguia a luta que, segundo Müller, parecia favorecer os portadores de pinças gigantes, pois existiam mais ou menos cem destes para cada olfativo. É interessante que, estudando o desenvolvimento desses crustáceos, Müller pôde polarizar de maneira irrefutável os estados dos caracteres - a pinça muito desenvolvida e o número maior de filamentos olfativos são estados derivados, pois não existem nos machos antes da muda que precede a maturidade sexual.

Outro caso que relatou foi o dos saltões da praia (Orchestia darwini) (Figuras 4 e 5), com duas formas de pinças no macho, segundo o meio em que vivem (próximo ao mar ou mais longe, rumo ao interior do continente):

Os machos seriam, indubitavelmente, considerados como pertencentes a duas espécies bem definidas, se não vivessem no mesmo lugar, com fêmeas iguais. O fato de haver duas formas de pinças de machos nesta espécie é igualmente digno de nota, porque a formação das pinças indica que faz pouco sofreu mudanças consideráveis e que, por isso, tal fenômeno deveria esperar-se nesta, mais do que em outra espécie (por viver em dois ambientes distintos). (Müller, 1864: 17)

Figura 4 - Orchestia darwini

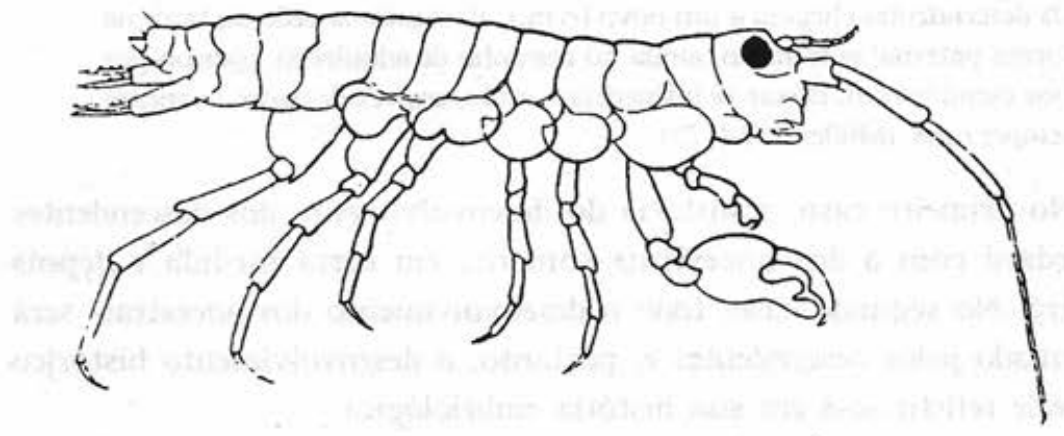

Fonte: Müller, 1864. 
Figura 5 - Ilustrações de Fritz Müller dos caracteres de Orchestia darwini. $(8,9)$ As duas formas de pinças dos machos de Orchestia darwini. (10) Lamelas coxais do penúltimo par de patas do macho, assim como a lamela coxal com os três segmentos seguintes do mesmo par de patas da fêmea de Melita messalina. (11) Lamelas coxais do mesmo par de patas de Melita messalina
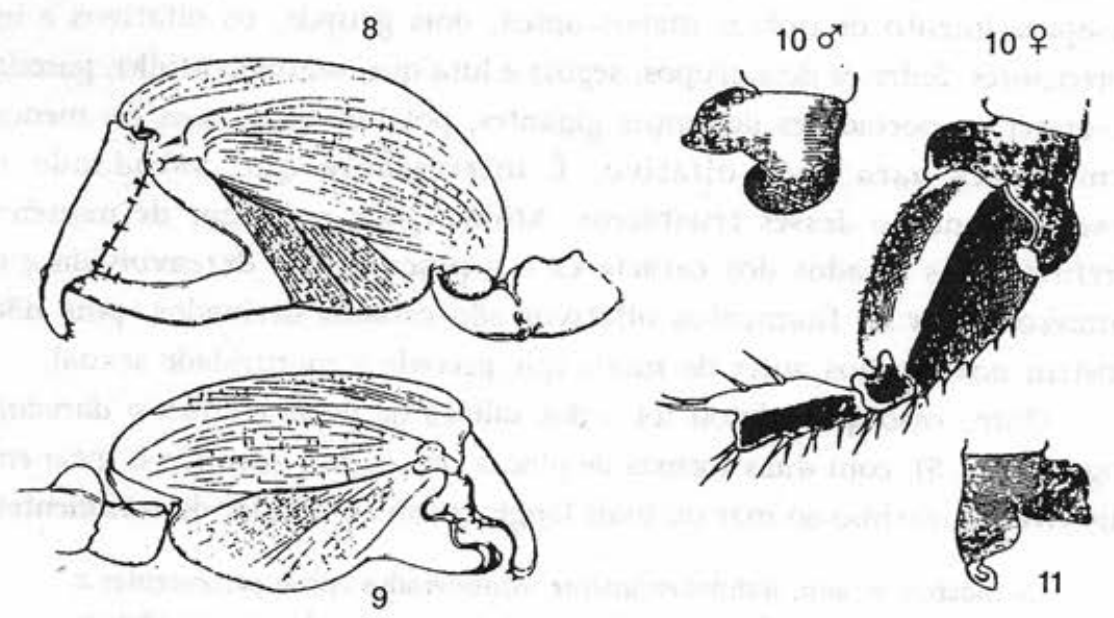

Fonte: Müller, 1864.

\section{O Estabelecimento da 'Lei Biogenética Fundamental'}

Para Fritz Müller, a evolução podia processar-se de duas maneiras:

Os descendentes chegam a um novo termo, afastando-se cedo ou tarde da forma paterna; entretanto, ainda no caminho de adquiri-lo, passam por esse caminho sem deixar-se influenciar; então, em vez de parar, avançam sempre mais. (Müller, 1864: 75)

No primeiro caso, a história do desenvolvimento dos descendentes concordará com a dos ancestrais somente em certa medida e depois divergirá. No segundo caso, todo o desenvolvimento dos ancestrais será recapitulado pelos descendentes e, portanto, o desenvolvimento histórico da espécie refletir-se-á em sua história embriológica. 
Um exemplo do segundo caso foi ilustrado por Müller com o desenvolvimento de um anelídeo tubícola. Comentou o grande naturalista:

Encontrei alguns pequenos tubos de vermes nas paredes de um de meus aquários, cujos habitantes tinham três pares de filamentos branquiais plumosos e não possuíam opérculo. Por isso, deveríamos referi-los ao gênero Protula. Poucos dias depois, um dos filamentos branquiais, por um espessamento de sua extremidade, gerou um opérculo clavado. Agora esses animais faziam recordar, por seu pendúnculo opercular plumoso, o gênero Filograna, com a única diferença que este possui dois opérculos. Três dias depois, durante os quais surgiu um novo par de filamentos branquiais, e quando o pedúnculo opercular havia perdido seus filamentos laterais, os vermes haviam-se convertido em uma Serpula. Aqui se apresenta, espontaneamente, a suposição de que os vermes tubícolas primitivos foram uma Protula, - que se modificaram depois para melhorar, pela formação de um opérculo que podia proteger seus tubos contra inimigos intrusos, $-\mathrm{e}$ que os descendentes destas últimas formas, finalmente, perderam os filamentos laterais do pedúnculo opercular, que haviam desenvolvido como em seus ancestrais. (Müller, 1864: 77)

A recapitulação, ainda assim, nem sempre é completa. A pressão de seleção pode fazer com que uma forma larval, por exemplo, adote "um caminho mais direto" ou mais curto, eliminando, durante seu desenvolvimento, várias fases morfológicas herdadas de seus ancestrais:

As formas históricas primitivas preservadas na embriogênese [recapituladas] apagam-se gradualmente, à medida que seu desenvolvimento se aproxima de um caminho cada vez mais direto, desde o ovo até o animal adulto, e isto muitas vezes é falseado pela luta pela sobrevivência que as larvas de vida livre têm que agüentar. (Müller, 1864: 78)

Segue-se que:

A história primitiva de uma espécie será preservada tão mais perfeitamente em sua embriogênese quanto maior for a série de estados jovens que atravessa com passos proporcionais, e tão mais verdadeira quanto menos o modo de vida do jovem se afaste do dos adultos e quanto menos as peculiaridades dos estados jovens possam ser concebidas como transferidas para trás, desde os períodos tardios até os períodos prévios da sua vida, ou como adquiridos independentemente. (Müller, 1864: 81)

No capítulo XII de seu livro, Müller ilustrou, com seus estudos de crustáceos, ambos os modos de 'recapitulação'. O camarão Peneus, com seu desenvolvimento longo e direto, fornecia a melhor ilustração da história ancestral dos Malacostraca, e os estados de náuplio e zoea (Figura 6) 
representavam importantes estados ancestrais. Nos outros grupos de crustáceos, distintos tipos de desenvolvimento, mais ou menos abreviados, surgiram por pressões seletivas. Então, o autor tentou fazer uma filogenia dos distintos grupos.

Figura 6 - Ilustrações de Fritz Müller do náuplio (28) e da zoea (29) de um camarão
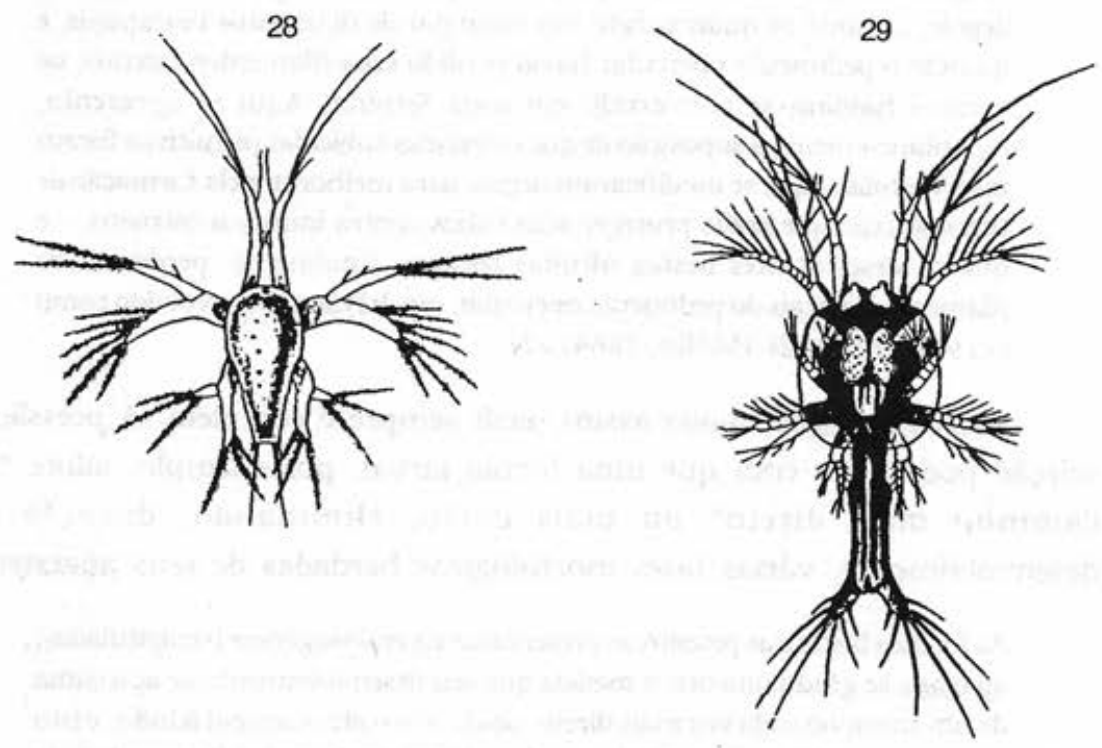

Fonte: Müler, 1864.

Haeckel utilizou as idéias de Müller, tornando-as pedras angulares de sua embriologia evolutiva e dando-lhes uma formulação mais precisa e mais técnica, sem acrescentar nada de essencialmente novo. Ele batizou tudo isso como 'lei biogenética fundamental' (Biogenetische Grundgesetz) para distinguir das leis de Meckel-Serres e de von Baer. ${ }^{3}$ De início, Haeckel repetiu, quase literalmente, as palavras de Müller:

A ontogenia, ou o desenvolvimento do indivíduo orgânico, sendo a série de mudanças morfológicas que cada organismo individual atravessa durante todo o tempo de sua existência individual, $e$ imediatamente condicionada pela filogenia, o seu desenvolvimento do estoque orgânico (phylon) ao qual pertence. 
A ontogenia é a recapitulação curta e rápida da filogenia, condicionada pelas funções fisiológicas de herança (reprodução) e adaptação (nutrição). $\mathrm{O}$ indivíduo orgânico (como o indivíduo morfológico da primeira até a sexta ordem) repete, durante o rápido e curto curso de seu desenvolvimento individual, as alterações morfológicas mais importantes do que seus antecessores atravessaram durante o longo e lento curso de sua evolução paleontológica, de acordo com as leis da herança e da adaptação.

A repetição completa e detalhada do desenvolvimento filético pelo biôntico apaga-se e abrevia-se por contração secundária, à medida que a ontogenia luta por seguir um caminho cada vez mais direto; por isso, a repetição [recapitulação] é tão mais completa quanto mais larga seja a série dos estados juvenis pela qual passa sucessivamente.

A repetição completa e detalhada do desenvolvimento filético pelo biôntico é falseada e alterada por adaptação secundária, pois o bion lO bion é o indivíduo fisiológico, tal como o 'morphon' é o indivíduo morfológico], durante seu desenvolvimento individual, se adapta a novas condiçōes: por isso, a repetição será tanto mais detalhada quanto maior seja a semelhança entre as condições de existência sob as quais se desenvolvem, respectivamente, o bion e seus ancestrais (Haeckel, 1866: 300).

Agora, portanto, o 'sistema natural' classificatório oferece-nos uma imagem verdadeira das relações genealógicas dos organismos, e os grupos - classificatórios menores e maiores correspondem a ramos menores e maiores da árvore filogenética. Para Haeckel, se a ontogenia é uma recapitulação da filogenia, devemos esperar encontrar no embrião uma repetição da organização do ancestral do phylon, em primeiro lugar, logo depois do ancestral da classe, depois do ancestral da ordem, da família, do gênero, aos quais pertence. Há, em conseqüência, um triplo paralelismo entre o sistema natural, a ontogenia e a filogenia (Haeckel, 1866).

Como comentou Russell (1982: 254-257):

Observa-se que aqui há implicada uma analogia entre a lei biogenética e a lei de von Baer, pois ambas afirmam que o desenvolvimento começa do geral até o especial, que quanto mais primitivo é o desenvolvimento encontramos mais generalizada a estrutura do embrião; ambos afirmam também que a diferenciação da estrutura ocorre, não em uma linha progressiva ou regressiva, mas em várias direções divergentes.

Porém, a analogia entre a lei biogenética e a lei de Meckel-Serres é ainda mais óbvia, e a semelhança entre as duas é muito mais fundamental. É um fato significativo que, em sua teoria do triplo paralelismo, Haeckel meramente ressuscitou, em forma evolutiva, uma doutrina amplamente discutida nos anos 40 e 50, particularmente defendida por Agassiz, doutrina que 
deve ser vista como uma extensão ou expansão da lei de Meckel-Serres. Esta dizia que existe um paralelismo entre o sistema natural, o desenvolvimento e a sucessão paleontológica (...).

A lei biogenética superou a lei de Meckel-Serres e a lei de von Baer porque reconhecia que a história ancestral da espécie é responsável em parte pelo curso que toma o desenvolvimento do indivíduo; que, num certo sentido, mas nunca da maneira crua suposta por Haeckel, a filogenia é a causa da ontogenia. Esse pensamento, de que o organismo é, antes de tudo, um ser histórico, está claro e implícito na idéia da evolução, sendo seu núcleo essencial. Se se retira esse elemento da lei biogenética - não é difícil - ela se torna uma lei da morfologia idealista, que se aplica à evolução considerada como um processo ideal - como o desenvolvimento progressivo do pensamento de Deus dos modelos arquetípicos.

Continua dizendo Russell (1982: 257-259):

Em sua Generelle Morphologie [1866] Haeckel havia reconhecido que a ontogenia não é nem uma recapitulação completa, nem inteiramente uma recapitulação detalhada da filogenia; admitia, seguindo Fritz Müller, que o curso verdadeiro da recapitulação era freqüentemente modificado por adaptações larvais e fetais. Com o tempo, foi forçado a insistir mais e mais neste ponto e, finalmente, em sua Anthropogenie [1874a], e em seu segundo trabaIho sobre a teoria da Gastrea [1874b], havia chegado a uma distinção entre caracteres palingenéticos e caracteres cenogenéticos, bastante utilizada por escritores subseqüentes.

A distinção pode ser feita seguindo as próprias palavras de Haeckel [no seu trabalho sobre a história da criação]: Aqueles processos ontogenéticos que podem ser atribuídos, de acordo com a lei biogenética, a uma forma ancestral independente desenvolvida completamente num período anterior, e transmitidos desta por herança, obviamente possuem importância primária para o entendimento das relações causais-fisiológicas; por outro lado, aqueles processos ontogenéticos que surgem subseqüentemente, através da adaptação às necessidades da vida embrionária ou larval, e que, de acordo com isto, não podem ser considerados como repetiçōes da organização de uma forma ancestral independente anterior, pode claramente ter, para o entendimento da história ancestral, somente uma importância secundária e bastante subordinada.

Aos primeiros chamei palingenéticos, e aos segundos cenogenéticos. Considerado sob esse ponto de vista crítico, o todo da ontogenia encontrase sob duas partes principais: a primeira, palingênese, ou 'história epitomizada' (Auszugsgeschichte), e a segunda, cenogênese, ou 'história falseada' (Falschungsgeschichte). A primeira é a epítome ontogenética verdadeira; a segunda é exatamente o contrário, um ingrediente forâneo novo, uma falsificação ou ocultamento do atributo da filogenia' (Haeckel, 1875: 409). 
Para que fossem definidos que processos eram palingenéticos ou cenogenéticos, Haeckel valia-se da anatomia comparada.

Na realidade, Haeckel insistiu muito mais nos casos regulares, em que aparentemente a ontogenia recapitula a filogenia, deixando quase esquecido o ponto principal defendido por Fritz Müller, de que a história do desenvolvimento dos descendentes concordará com a dos ancestrais somente em certa medida e depois divergirá. ${ }^{4}$

Foram muitas as contribuições de Fritz Müller à teoria darwinista. Sua obra, Für Darwin, desenvolvida em ambiente primitivo, sem biblioteca adequada, equipamento e recursos, tornou-se um marco para a consolidação da teoria Darwin em todo o mundo.

\section{Notas}

1 "Sobre as sanguessugas observadas até agora nas cercanias de Berlim".

2 "O qual ampliou por meio de importantíssimas observações a ciência zoológica e botânica, e também pelas pesquisas baseadas na evolução dos crustáceos do litoral brasileiro, baseadas na nova e importantíssima doutrina de Darwin, em cujo apoio veio" (Tradução livre).

3 Para as leis de Meckel-Serres e von Baer, ver Papavero \& Llorente-Bousquets (1995).

4 Para uma visão mais ampla das idéias de Haeckel, especialmente da sua lei biogenética fundamental e das tristes conseqüências que teve em pedagogia, educação, psicanálise e até na guerra do Vietnã, é preciso ler o luminoso ensaio de Gould (1978).

\section{Referências Bibliográficas}

DARWIN, C. On the Origin of Species by Means of Natural Selection, or The Preservation of Favoured Races in the Struggle for Life. Londres: John Murray, 1859.

GOULD, S. J. Ontogeny and Phylogeny. 3.ed. Cambridge, Massachusets \& Londres: The Belknap Press of Harvard University Press, 1978.

HAECKEL, E. H. P. A. Generelle Morphologie. Allgemeine Grundzüge der Organischer FormenWissenschaft, Mechanisch Gegründet Durch Die von Ch. Darwin Reformierte DescendenzTheorie. Berlim: Georg Reimer, 1866. v.1: Allgemeine Anatomie der Organismen; v.2: Allgemeine Entwicklungsgeschichte der Organismen).

HAECKEL, E. H. P. A. Anthropogenie oder Entwicklungsgeschichte des Menschen. Leipzig: s.n., 1874a.

HAECKEL, E. H. P. A. Die gastraea-theorie, die phylogenetische classification des thierreichs und die homologie der keimblätter. Jenaische Z. Med. Naturwiss, 8: 1-55, 1874b. 
HAECKEL, E. H. P. A. The History of Creation. Londres: John Murray, 1875. (Tradução do alemão por Miss L. D. Schmitz e revisão de E. R. Lankester) $2 \mathrm{v}$.

MÖLLER, A. (Ed.) Fritz Müller. Werke, Briefe und Leben. Erster Band: gesammelte schriften, soweit die bereits früher im druck erschienen sind. Jena: Gustav Fischer, 1915. (Text. Abteilung 1: Arbeiten aus den Jahren 1844-1879 (Nr. 1-124). 5v.

MüLLER, J. F. T. Für Darwin. Leipzig: Verlag von Wilhelm Engelmann, 1864.

MÜLLER, J. F. T. Facts and Arguments for Darwin. Londres: John Murray, 1869. (Traduzido do alemão por W. S. Dallas)

NOMURA, H. Fritz Müller: fatos e argumentos a favor de Darwin. Florianópolis: Fundação Catarinense de Cultura, 1990.

PAPAVERO, N. \& LLORENTE-BOUSQUETS, J. Principia taxonomica: una introducción a los fundamentos lógicos, filosóficos y metodológicos de las escuelas de taxonomía biológica. México, D. F.: Wallace y Darwin. Coordinación de Servicios Editoriales, Facultad de Ciencias, Universidad Nacional Autónoma de México, 1994. v.5

PAPAVERO, N. \& LLORENTE-BOUSQUETS, J. Principia taxonomica: una introducción a los fundamentos lógicos, filosóficos y metodológicos de las escuelas de taxonomía biológica. Analogía y conceptos relacionados en el periodo pre-evolutivo. México, D. F.: Coordinación de Servicios Editoriales, Facultad de Ciencias, Universidad Nacional Autónoma de México, 1995. v.5

PAPAVERO, N. \& LLORENTE-BOUSQUETS, J. Principia taxonomica. Una introducción a los fundamentos lógicos, filosóficos y metodológicos de las escuelas de taxonomía biológica. México, D.F: Coordinación de Servicios Editoriales, Facultad de Ciencias, Universidad Nacional Autónoma de México, 1996. v.7

RIBEIRO, A. de M. [sob o pseudônimo "Cryptus"] Por Darwin. Kosmos, 4-5: (sem paginação).

RUSSELL, F. S. Form and Function: a contribution to the history of animal morphology. Chicago/ Londres: The University of Chicago Press, 1982.

SPENCE BATE, C. Crustacea. In: GÜNTHER, A. C. L. G. (Ed.) The Record of Zoological Literature. Londres: John van Voorst, 1865. v.1 


\section{O Evolucionísmo na Produção Cíentífica do Museu Nacional do Río de Janeíro (1876-1915)}

Regina Cândida Ellero Gualtieri

\section{Introdução}

No final do século XIX, o país estava tentando se transformar política, econômica e socialmente, circunstância receptiva a idéias evolucionistas, como as de seleção natural e de luta pela vida, de Charles Darwin (18091882); de recapitulacionismo, de Ernst Haeckel (1834-1919); e de determinismo histórico, de Herbert Spencer (1820-1903).

As concepções de seleção natural e de luta pela vida poderiam ser utilizadas para combater, em nome das transformações pretendidas, a pretensa apatia e a incompetência dos opositores; já a lei biológica de Haeckel, transferida para o mundo social, previa que os povos, durante seu desenvolvimento, recapitulariam a história de outros povos já desenvolvidos e, na interpretação spenceriana, as organizações sociais mais simples e menos evoluídas se transformariam, seguindo os passos das sociedades mais complexas.

Tais convicções evolucionistas permitiam a seus adeptos ter uma visão otimista quanto à possibilidade de o Brasil superar o que consideravam atraso econômico, social e político. Bastava a eles olhar as nações mais civilizadas para compreenderem a direção a seguir. Espelhando-se na Europa, poderiam propor transformações que levassem à queda da monarquia, à extinção do trabalho escravo e à introdução do trabalho livre, dentre outras tarefas.

Ilustrativas dessas concepções são as observações do evolucionista Sylvio Romero (1851-1914), que, mesmo manifestando seu receio, 
concordou com Tobias Barreto (1839- 1889), ambos da Escola do Recife, quando este conclamou os intelectuais brasileiros a procurarem na Alemanha inspiração para uma reforma intelectual. "Este pedaço deve ser entendido habilmente", observou, acrescentando,

\begin{abstract}
em regra, não é um bom exemplo aconselhar a uma nação que siga a outra; mas isto deve se compreender com relação aos grandes povos, àqueles que podem representar um papel original na historia. Para com os povos medíocres, ou quase nulos, a coisa muda muito de figura. Eles devem ser compelidos a tomar os avisos salutares, sob pena de perda irremediável. Impróprios para reformarem-se por si, hão mister de uma escola severa fornecida pelo estrangeiro. (Romero, 1969: 137)
\end{abstract}

Digna de nota também é a visão 'fatalista' de Arthur Orlando (18581916), ${ }^{1}$ também da Escola do Recife, para quem a humanidade caminhava em direção à República e, portanto, não se tratava sequer de saber se a República era melhor do que a monarquia: ela era inevitável (Orlando apud Barros, 1986).

Vários estudos têm sublinhado o fato de que essas correntes evolucionistas continham elementos que se encaixavam perfeitamente no projeto de transformação do país que estava sendo forjado por uma parte de nossas elites. Os trabalhos de Cruz Costa $(1967,1985)$ procuram verificar, sobretudo, a contribuição das idéias evolucionistas inspiradas nas obras de Darwin, Spencer e Haeckel para o pensamento filosófico brasileiro. Cruz costa admite que esse núcleo de idéias deu argumentos para o debate dos problemas políticos, econômicos e sociais travado no final do século XIX, mas considera que os parâmetros evolucionistas não fertilizaram o campo teórico de modo a contribuir para uma produção filosófica nacional que fosse genuína.

Ao examinar as obras de alguns representantes do evolucionismo, Cruz Costa tece criticas, principalmente, pela falta de originalidade; incluindo aí as obras de Tobias Barreto, considerado por Cruz Costa um filósofo não original e tampouco um pensador. "Foi, como tantos outros letrados que temos tido, um comentador do pensamento europeu e, especialmente, do pensamento alemão". Um dos poucos que escaparam à sua crítica foi Sylvio Romero, considerado "o precursor do esforço de interpretação do Brasil"; pois foi a partir dele, segundo Cruz Costa, que os problemas nacionais, em especial aqueles relacionados à história da cultura, ganharam a atenção de nossos intelectuais (1967: 293, 297). 
$\mathrm{Na}$ interpretação desse autor, entretanto, o evolucionismo atendeu aos interesses da elite brasileira, que viu, principalmente na vertente do spencerismo, a "síntese filosófica que justificava a sua atitude política, social e até religiosa" (1967: 281). A "lei da diferenciação progressiva" e "a noção de aperfeiçoamento indefinido do indivíduo" corresponderam aos desejos da "nova classe de bacharéis e doutores e libertava-os, ao mesmo tempo, das crenças teológicas sem os obrigar a aderir à religião da Humanidade" (1967: 281).

Paim (1975) destaca a falta de coerência entre as doutrinas assimiladas no século XIX, particularmente na década de 70. Em seu julgamento, nesse momento, houve, talvez, convergência apenas de objetivos, pois "tratava-se de combater os suportes teóricos da monarquia, entendida como obstáculo ao progresso. Assim, apanhavam-se indiscriminadamente as idéias de Comte, Darwin, Taine, Renan e outros, constituindo o que chamou de uma espécie de 'frente cientificista'" (1975: 14).

Contrariamente a Cruz Costa, Paim (1974) reserva a Tobias Barreto um lugar especial na formação da cultura brasileira, porque, no seu entendimento, foi esse pensador quem, pela primeira vez, trouxe, para o debate, o tema da consciência, na abordagem da pessoa humana. Nesse aspecto, julga original a contribuição de Tobias Barreto.

Uma outra interpretação acerca do significado das idéias evolucionistas para a história social brasileira encontra-se em Barros (1986). Sua percepção sobre o sucesso de idéias cientificistas, como o positivismo e o darwinismo, entre os intelectuais da época, é a de que tais doutrinas forneceram o instrumental para compreender e explicar a realidade nacional e formular um 'programa de ação'. Os positivistas e darwinistas, para Barros, não pretendiam "construir à força uma vida e um pensamento originais", mas sim integrar o país no movimento universal, colocando-o "ao nível do século" (1986: 167-168). Ele afirma que o papel desses intelectuais era precisamente o de 'apressar a marcha do país' para cumprir sua trajetória, já que acreditavam ser a nossa história obediente às mesmas 'leis fatais' da história universal.

Os darwinistas de matiz haeckeliana, aplicando à história a lei filogenética fundamental, crêem que, da mesma forma que o indivíduo recapitula a história da espécie, um povo há de recapitular também a história de outros povos, cujo conjunto constitui a evolução da humanidade. (Barros, 1986: 169 - Grifos do autor) 
Evoluir, no Brasil do século XIX, significava, dentre outros aspectos, derrubar a monarquia, tornar livre o trabalho, privilegiar a livre concorrência, reexaminar a concepção de Estado.

Esse entendimento também está presente no trabalho de Collichio (1988) sobre a recepção do darwinismo no Brasil. A autora estudou a atuação de Miranda Azevedo, médico e divulgador do darwinismo, como também as idéias de outros defensores do evolucionismo, concluindo que a adoção da teoria se deu em correspondência ao ideário nacional, em associação, portanto, com a problemática então em debate. Para Collichio, essa união "refletia ao mesmo tempo a independência intelectual dos adeptos e a intenção comum deles de desmoralizar, para derrubar, um regime político que acreditavam representar idéias e instituições insustentáveis em face do progresso da ciência" (1988: 21).

A autora constata que, para esses intelectuais, as idéias centrais de Darwin - luta pela vida, seleção natural - converteram-se em instrumentos de explicação da realidade política e social e tornaram-se o argumento considerado científico "no combate à apatia ou à incompetência em áreas específicas, como ensino, política, literatura, saúde pública, direito, economia, e à 'filosofia de vida' do brasileiro em geral". Serviram, igualmente, de suporte "à posição liberal republicana, porquanto a monarquia constituía o primeiro obstáculo ao 'progresso'" (1988: 18-19).

Collichio mostra, além disso, que os trabalhos de Miranda Azevedo, tanto os relativos aos problemas sociais quanto os ligados à medicina, à biologia, à mineralogia e à climatologia receberam forte influência darwinista; ele era haeckeliano e esteve na vanguarda da divulgação das idéias evolucionistas, ao participar, em 1875, das célebres 'conferências populares' da Freguesia da Glória, no Rio de Janeiro. ${ }^{2}$ Ao analisar o conteúdo dessas conferências, a autora destaca inúmeras inferências, extraídas da doutrina, relativas aos problemas sociais e políticos do Brasil, mas não identifica nenhuma formulação que pudesse representar algo original relativamente ao pensamento darwinista (1988: 41). Essa constatação contribuiu para que a autora viesse a caracterizá-lo apenas como divulgador do evolucionismo.

Collichio reconhece, porém, que as idéias, vulgarizadas por Miranda Azevedo, juntamente com as propagadas por Tobias Barreto e seus discípulos, invadiram o campo do direito, da literatura, do teatro e da pedagogia, "abalando fortes estruturas obsoletas" (1988: 42). Admite também que "seria insensato desprezar a contribuição do pensamento evolucionista 
para a elaboração de uma antropologia filosófica no Brasil do nosso século" (1988: 113-114). Todavia, "do ponto de vista da história das ciências", conclui que, apenas mais tarde, o pensamento evolucionista ganhou relevo, pois "os cientistas brasileiros só no meado do século XX despertariam para as conquistas da biologia, oferecendo relevante contribuição a essa ciência André Dreyfus, Theodor Dobzhansky e o grupo de jovens pesquisadores da Universidade de São Paulo formados por eles" (1988: 114).

Entretanto, essa conclusão relativa à contribuição do evolucionismo para a ciência brasileira é precipitada, pois, como a autora ressalta, seu trabalho não tencionou escrever a história do darwinismo no Brasil, "tarefa ampla, ainda por realizar" (1988: 21). Precisamente em relação a essa contribuição, seu estudo não contém elementos suficientes e seguros que permitam afirmar a generalização pretendida.

Schwarcz (1995), ao tentar compreender como o argumento racial foi política e historicamente construído, mostra de que forma as idéias evolucionistas, traduzidas nas vertentes do evolucionismo cultural e do darwinismo social, foram apropriadas, de modo original, pelos intelectuais brasileiros para elaborar a teoria racial que ganhou expressão na virada do século até os anos 30 .

A autora demonstra que essas duas vertentes do darwinismo eram incompatíveis em sua essência, pois o evolucionismo cultural era adepto do monogenismo e da visão unitária da humanidade. Nessa interpretação, as diferenças existentes entre as raças humanas seriam apenas transitórias, transformáveis, naturalmente, ao longo do tempo, ou pelo contato cultural. O darwinismo social, ao contrário, partilhava do modelo poligenista e da concepção de que os homens dividiam-se em espécies diferentes. Essa vertente entendia as diferenças humanas como definitivas e irreparáveis e, desse modo, a evolução social única e geral constituiria um engano, já que, a civilização seria um estádio acessível a poucos. No entanto, argumenta a autora, "aqui se fez um uso inusitado da teoria original, na medida em que a interpretação darwinista social se combinou com a perspectiva monogenista. O modelo racial servia para explicar as diferenças e hierarquias, mas, feitos certos rearranjos teóricos, não impedia pensar na viabilidade de uma nação mestiça" (1995: 65).

Alguns outros estudos têm feito referência, ainda que de forma pontual, à presença de idéias evolucionistas em outros âmbitos, como na prática científica de instituições, expressa por meio das atividades de seus 
pesquisadores. Neiva (1929), Mello Leitão (1937) e Azevedo (1963) destacam, particularmente, os trabalhos do alemão Fritz Müller (1821-1897). Radicado no Brasil desde 1852, Müller foi naturalista viajante do Museu Nacional por mais de uma década, e suas contribuições para o pensamento evolucionista tornaram-se conhecidas internacionalmente, até pelo próprio Darwin.

Estudos recentes têm ampliado essas informações. O próprio trabalho de Schwarcz (1995) revela a influência do darwinismo social nas atividades dos museus etnográficos e de história natural, dos institutos históricos e geográficos, das faculdades de direito e de medicina do Brasil. O Museu Nacional do Rio de Janeiro, o de São Paulo e o Goeldi do Pará, por exemplo, tinham em seus quadros, desde o final do século, cientistas reconhecidos publicamente como evolucionistas - respectivamente, João Batista de Lacerda, Hermann von Ihering e Emílio Goeldi. No mesmo período, no tocante às ciências médicas, as faculdades de medicina do Rio de Janeiro e, particularmente, da Bahia, com Nina Rodrigues, além de terem sido centros de geração de idéias baseadas no modelo social-darwinista, que associava as doenças e as epidemias à questão racial, produziram outros conhecimentos ligados à área médica e também às ciências naturais.

Lopes (1997), estudando os museus brasileiros no século XIX, também revela que a atuação destes, a partir de 1870, esteve orientada pelos paradigmas do positivismo, do evolucionismo e do naturalismo Os novos parâmetros inspiraram a renovação institucional não só porque favoreceram a introdução dos estudos experimentais, rompendo com a tradição exclusivamente naturalista anterior, mas também por propiciarem o desenvolvimento de estudos antropológicos sustentados por teorias raciais.

Sá \& Domingues (1996), em um estudo mais específico sobre as atividades de ensino realizadas pelo Museu Nacional, nos anos de 1870 e 1880, registram que os cursos de ciências naturais oferecidos pelos pesquisadores da instituição geravam polêmicas por causa das novas teorias de que tratavam, sobre a evolução dos seres vivos.

As indicações desses textos estimularam a realização de uma investigação que revelasse com mais especificidade a influência das idéias evolucionistas nas atividades científicas ${ }^{3}$ de instituições brasileiras do final do século XIX e início do XX. O presente trabalho analisa, particularmente, essa influência nas atividades do Museu Nacional do Rio de Janeiro. ${ }^{4}$

Busco, neste artigo, não só trabalhar a recepção de idéias, verificando se houve, em um determinado espaço e tempo, a divulgação de certas teorias 
e de que maneira foram recebidas pelos cientistas. Pretendo mais do que isso: constatar se ocorreu a efetiva incorporação das idéias evolucionistas na prática científica da instituição e de que forma isto se deu.

A partir da análise dos trabalhos realizados pelos pesquisadores, a maior parte deles publicada na revista editada pelo próprio Museu Nacional, e de documentos institucionais, como relatórios de atividades, comunicações internas, ofícios, normas de organização, procuro mostrar a natureza das práticas $^{5}$ e sua sintonia com as inovações científicas da época, particularmente as decorrentes das teorias de Darwin. Para tanto, são consideradas as condições sociais nas quais as atividades se desenvolveram e influíram; além disso, condições pessoais e motivações dos pesquisadores, assim como algumas especificidades da instituição - finalidades, organização interna -, são também levadas em conta, com o intuito de compreender as escolhas dos cientistas e as alterações oportunistas ou criativas que introduziam nas teorias em função de critérios sociais e/ou religiosos.

O período estudado abrange desde os anos posteriores a 1870 , reconhecido marco para a entrada das idéias evolucionistas no Brasil, até meados da segunda década do século XX, intervalo de tempo no qual houve, no Museu, grande produção voltada para as ciências naturais e à frente de sua administração, conforme já mencionado, estiveram cientistas que se identificaram publicamente com idéias evolucionistas: Ladislau Netto (1875-1893) e João Batista de Lacerda (1895-1915).

A análise pretende mostrar a natureza dos textos científicos, principalmente os voltados para a zoologia e a Botânica, identificando em seus temas e conteúdos os referenciais teóricos utilizados e a possível influência das várias teorias evolucionistas que vinham sendo divulgadas no Brasil desde 1870. Em essência, busco nesses textos, a existência dos referenciais do darwinismo biológico, expostos por Darwin em $A$ Origem das Espécies (1859), e a forma de incorporá-los. Dentre esses referenciais, procuro, sobretudo, a presença das idéias de que o mundo material e orgânico estão em permanente transformação; os organismos vivos descendem de um mesmo ancestral comum (a origem única da vida na Terra); as espécies não são fixas e se diversificam ou desaparecem ao longo do tempo; as novas espécies surgem a partir de mudanças graduais, ${ }^{\circ}$ e, conseqüentemente, a evolução ocorre de modo gradual e não aos saltos; e a seleção natural ${ }^{7}$ é responsável pelas mudanças evolutivas. Para os trabalhos de zoologia, os referenciais do haeckelismo, em particular o recapitulacionismo, também são considerados. 
Observo, contudo, que as diferentes idéias evolucionistas não são vistas como conhecimento pronto e rotulado, do qual o cientista lança mão, em uma ou outra de suas variantes, por conta de uma escolha unívoca. Pelo contrário, sou guiada pelo pressuposto de que os cientistas criam, desenvolvem ou incorporam conceitos e teorias em um contexto particular e sob sua influência. ${ }^{8}$ Eles não são puros "sujeitos do conhecimento", mas são também resultados de circunstâncias, de um certo meio cultural, de seu itinerário formativo, de contatos que estabelecem com determinados grupos, partilhando com eles suas atividades. ${ }^{9}$ Como diz Rosenberg (1988: 567 ), em algum nível, a integração entre o contexto e a cognição necessariamente ocorre nos "corações e mentes" dos atores científicos. Esses referenciais são importantes para entender as opções teóricas dos naturalistas e as alterações que, eventualmente, introduzem nas teorias utilizadas em seus trabalhos.

\section{A Instituição na Transição do Império para a República: a modernização pretendida}

No ano de 1868, o Museu Nacional passou a se subordinar ao Ministério da Agricultura, Comércio e Obras Públicas. Até então, era vinculado ao Ministério dos Negócios do Império, no qual, ao lado das demais instituições de ensino, integrava, desde 1843 , a seção de 'Instrução Pública'. ${ }^{10}$ Essa transferência estava relacionada com as expectativas que se nutriam em relação ao papel que o Museu poderia desempenhar naquele momento em que determinadas atividades econômicas tomavam impulso. ${ }^{11}$

Em relatório datado de 1870 , o ministro da Agricultura, Cavalcanti Albuquerque, afirmou: "o quase abandono em que se encontrava o Museu é contrastante com o apreço dos povos civilizados por instituições dessa natureza". No entanto, acrescentou, "já é fato constatado que, por prestarem poderoso auxílio ao estudo das ciências, exerciam influência decidida no desenvolvimento da indústria". ${ }^{12}$ Em seguida, solicitou mais recursos para que o ministério pudesse garantir o desenvolvimento da instituição de modo compatível com a "missão civilizadora" que deveria cumprir (Albuquerque, 1870: 88).

Quando as funções que o Museu vinha desempenhando são cotejadas com as observações do ministro, torna-se perceptível que essa 'missão civilizadora' desdobrava-se, efetivamente, em três. 
Uma delas decorria diretamente de sua atividade produtora de conhecimento científico. Dentre as tarefas do Museu, destacavam-se inventariar, classificar e colecionar as riquezas do Brasil - fauna, flora, minerais, madeiras - verificar a qualidade dos combustíveis fósseis e traçar a história dos povos primitivos, os indígenas. ${ }^{13}$ Algumas dessas funções sistematizavam informações importantes que poderiam contribuir para o desenvolvimento de determinadas atividades econômicas no país, como, por exemplo, a produção fabril e artesanal da década de 70 ligada à mineração de ferro, cal, mármore, xisto betuminoso; o preparo de gás e óleos minerais; a produção de artefatos cerâmicos; oficinas e fundições para artefatos de ferro; o preparo de madeira para construções e outros fins, além da fabricação de mobiliário e a indústria têxtil (Ianni, 1985).

A outra missão vinculava-se às funções pedagógicas do Museu, sobre as quais, no relatório datado de 1871 , o ministro referiu-se como sendo

auxiliar à instrução do povo, habilitando-o a conhecer, por meio de preleções públicas e a seu alcance, os recursos que o comércio, a indústria e as artes podem tirar dos nossos vegetais e minerais que admiram, pela sua profusão e variedade, os homens mais doutos do mundo. (Silva, 1871: 66)

Ladislau Netto, funcionário do Museu desde 1866, que assumiu gradativamente posições importantes na hierarquia da instituição até chegar à sua direção no início de 1875 , estava convencido da importância dessa missão pedagógica e, em várias oportunidades, ${ }^{14}$ reivindicou condições materiais e financeiras que permitissem a realização de cursos públicos. Em suas palavras, constituía uma das principais finalidades da instituição "instruir o povo, inoculando no espírito da mocidade estudiosa o gosto das pesquisas científicas, alentando ou guiando a indústria nacional e tornandose finalmente o árbitro de todas as questões relativas aos tesouros contidos em nosso vasto território" (Silva, 1871: 5). Tal afirmação mostra que Ladislau Netto compreendia como essencial o papel do Museu na formação dos indivíduos e no desenvolvimento das atividades econômicas do país.

Para a missão de difundir o saber, o Museu incluiu, ainda, a publicação de uma revista intitulada Archivos do Museu Nacional ( $A M N$ ). A leitura da documentação deixa entrever que a revista seria o meio privilegiado de comunicação entre os cientistas e a sociedade. ${ }^{15}$ Era deliberada a intenção do diretor de que os trabalhos do Museu fossem divulgados para revelar não só aos brasileiros, mas também aos estrangeiros, o grau de desenvolvimento científico do país. Essa atividade de divulgação ensejaria 
sua terceira missão: colaborar na construção de uma nova imagem do país que rompesse com a idéia de barbárie cultural que costumava transmitir e permitisse colocar o Brasil na marcha civilizatória da humanidade.

São dignos de nota dois registros de Ladislau Netto a esse respeito. Comentando o lançamento do perí́dico em seu relatório de 1876, enfatizou que a revista seria

para os países estranhos, ou antes, para o vastíssimo orbe das ciências e das letras que não conhecem delimitação à pátria, os mais belos fatos do nosso avanço no estádio da civilização a cujos olhos constituir-se-ão testemunhos tão eloqüentes quão pouco ostentosos, de que unicamente por suspicaz imputação nos podem macular com o deslouvor de retrógrados e de indolentes. (Netto, 1877: 4)

Reforçou essa visão nas páginas introdutórias do primeiro volume dos Archivos, ao afirmar que o Museu Nacional, em sua nova constituição, se preparava para se vincular aos grêmios científicos e aos congressos da civilização $(A M N, 1876)$.

A preocupação em transformar a instituição em um ponto de luz no território brasileiro visível em outros continentes, em especial a Europa, foi várias vezes reiterada nas exposições do diretor do Museu. Referindo-se às iniciativas que certamente facilitariam o crescimento do prestígio da instituição fora do âmbito do Império ele mencionou a nomeação dos 'membros correspondentes do Museu', título recebido por aqueles que tivessem reconhecido mérito literário e científico e serviços prestados ao estabelecimento. ${ }^{16}$ Logo nas páginas iniciais dos Archivos, publicava-se a lista desses ilustres membros. Nomes como Darwin, Hooker, Quatrefages e Virchow figuravam ao lado de expressões de vulto no cenário nacional, como Domingos Ferreira Penna. A respeito desses membros, Ladislau Netto mostrou, de modo explícito, que papel estes preencheriam na tarefa de dar visibilidade à instituição. Observou que com tais paraninfos "não pode deixar de crescer e medrar fora do Império o prestígio de uma instituição desta arte auspiciada" (Netto, 1877: 5).

Diante dessas considerações, é pertinente concluir que o surgimento dos Archivos ocorreu no momento em que ao Museu estavam reservadas algumas missões que colaborariam no processo de modernização do país, tanto no campo científico e cultural quanto no econômico. A criação da revista esteve especialmente associada à intenção de que seu conteúdo pudesse revelar ao mundo civilizado o quanto o país estava sintonizado com os 
avanços científicos que estavam ocorrendo. De fato, o esforço da instituição para divulgar a revista é notável, considerando seus registros sobre os países e as entidades nacionais com os quais intercambiou periódicos. ${ }^{17}$

As publicações dessa revista constituíram material privilegiado de estudo do presente trabalho no que se refere à prática científica do Museu Nacional. Foram realizadas as análises dos textos publicados no período correspondente à transição do Império para a República, especificamente os anos em que o Museu esteve sob a administração de Ladislau Netto (1875-1893), como também no período posterior, referente aos anos iniciais da República, quando o Museu esteve sob a direção de João Baptista de Lacerda (1895-1915).

\section{A Produção Científica na Administração Ladislau Netto (1875-1893)}

Durante os 18 anos da administração de Ladislau Netto, foram publicados oito volumes dos Archivos com 56 estudos, distribuídos por várias áreas de conhecimento, conforme mostrado na Tabela 1.

Tabela 1 - Número de trabalhos publicados nos $A M N$ por tema e por volume. Brasil - 1876-1892

\begin{tabular}{l|c|c|c|c|c|c|c|c|c}
\hline $\begin{array}{l}\text { Vol./Área de } \\
\text { conhecimento }\end{array}$ & $\begin{array}{c}\text { I } \\
(1876)\end{array}$ & $\begin{array}{c}\text { II } \\
(1879)\end{array}$ & $\begin{array}{c}\text { III } \\
(1878)\end{array}$ & $\begin{array}{c}\text { IV } \\
(1876)\end{array}$ & $\begin{array}{c}\text { V } \\
(1876)\end{array}$ & $\begin{array}{c}\text { VI } \\
(1876)\end{array}$ & $\begin{array}{c}\text { VII } \\
(1876)\end{array}$ & $\begin{array}{c}\text { VIII } \\
(1876)\end{array}$ & Total. \\
\hline Zoologia & 02 & 05 & 04 & 03 & & & & 05 & $19(34 \%)$ \\
\hline Fisiologia & 01 & 02 & 02 & 01 & & & & & $06(11 \%)$ \\
\hline Arqueologia & 04 & 04 & & & & 01 & & & $09(16 \%)$ \\
\hline Paleontologia & & & & & & & 01 & & $01(2 \%)$ \\
\hline Botânica & 01 & & & & 01 & & & & $02(4 \%)$ \\
\hline Geologia & & 01 & 04 & 02 & & & & & $07(12 \%)$ \\
\hline Antropologia & 02 & & & 02 & & 03 & & & $07(12 \%)$ \\
\hline Outros* & & 01 & 01 & & & & & 03 & $05(9 \%)$ \\
\hline Total & 10 & 13 & 11 & 08 & 01 & 04 & 01 & 08 & 56 \\
\hline
\end{tabular}

* Incluem-se nessa categoria os editoriais, prefácios, necrológios e relatórios. 
Nas décadas de 70 e 80 do século XIX, o Museu realizou estudos que buscaram discutir questões relativas à origem do homem americano (ver Tabela 1). Os estudos arqueológicos e antropológicos, particularmente os de Antropologia física, se expandiram naqueles anos, não só no Brasil, pelo grande interesse dos cientistas em estabelecer as origens dos diferentes povos. Como ressalta Gould (1991: 111), "uma vez demonstrada a evolução, os naturalistas do século XIX devotaram-se a estabelecer os verdadeiros caminhos que ela seguira (...) procuraram reconstruir a árvore da vida". Assim, uma das investigações mais relevantes para o Museu era a que se referia à origem dos povos americanos. Em um de seus artigos, Ladislau Netto, ao mencionar que ainda não era possível afirmar se "os povos da região cisandina tinham origem comum com os antigos povos das demais regiões do globo", manifestou sua conviç̧ão de que, a partir das pesquisas que estavam sendo realizadas, caberia ao Museu, "em não mui remoto futuro, a gloriosa missão de quebrar o sigilo que prende e oculta o fecho desses assuntos" (AMN, 1879: 107). Em outra oportunidade, até para justificar o abandono de suas pesquisas na área de Botânica para se dedicar à Arqueologia e à Etnologia, ele mencionou: "o estudo de nossos índios, prestes a desaparecerem completamente, constitui uma das necessidades mais urgentes e a mais alta missão do momento" (Netto, 1889: 26).

Em 1882, em uma evidente demonstração da importância que se atribuía ao assunto, o diretor planejou um grande evento, a Exposição Antropológica, com o fim de exibir crânios, esqueletos e artefatos de tribos indígenas que povoaram (ou ainda povoavam) o território brasileiro. $\mathrm{Na}$ solenidade de abertura, Ladislau Netto, perante o Imperador e o público, pronunciou-se, sem modéstia, destacando que

este é o certame mais nacional que as ciências e as letras poderiam, congratuladas, imaginar e realizar no fito de soerguer o Império do Brasil, ao nível da intelectualidade universal, na máxima altura a que pode ela atingir, além do Atlântico e nas extremas luminosas ao norte do continente americano. (Netto apud Duarte, 1950: 167)

A valorização atribuída pelo Museu aos estudos relativos às origens do povo americano também deve ser compreendida, considerando-se as especificidades da sociedade brasileira do século XIX, incitadoras das discussões que visavam a esclarecer a unidade ou não da origem dos diferentes povos, identificadas, respectivamente, pelas concepções monogenistas e poligenistas. Esses conhecimentos eram, naquele momento, 
essenciais para delinear a evolução social e política de uma nação composta de um povo miscigenado e marcado, de acordo com as teorias da época, pela inferioridade racial. ${ }^{18}$

Em uma outra vertente de pesquisa, estavam os trabalhos experimentais de fisiologia do Museu, que, nessa fase, produziu investigações predominantemente referentes à ação de substâncias tóxicas - venenos de origem vegetal ou animal - e sobre os organismos. ${ }^{19} \mathrm{O}$ autor dos escritos foi João Baptista de Lacerda, médico de formação, que, durante a administração de Ladislau Netto, ocupou os cargos de subdiretor e, posteriormente, diretor da seção de zoologia até 1891 . Os trabalhos realizados na área eram experimentais e procuraram, por exemplo, testar se as conclusões obtidas por Claude Bernard, estudando espécies européias, eram válidas para os animais brasileiros com os quais Lacerda realizava as investigações ( $A M N$, 1878), ou ainda completar as informações do fisiologista francês, ao demonstrar a origem do veneno presente nas flechas dos índios sulamericanos, cuja ação foi identificada por Bernard ( $A M N, 1876)$.

As investigações em fisiologia foram fortalecidas no Museu quando o próprio Lacerda juntamente com o médico parisiense Louis Couty (18541884), entusiasta dos estudos experimentais, fundaram o Laboratório de Fisiologia Experimental, que funcionou anexo ao Museu Nacional entre 1880 e 1890. Desse laboratório, relatou Lacerda (1905: 108), "saíram comunicações importantes para a Academia das Ciências de Paris, memórias de valor para revistas e jornais estrangeiros e uma descoberta, que fez convergir para o Brasil a atenção de todo o mundo civilizado". Trata-se de sua 'descoberta' referente à ação do permanganato de potássio sobre as mordeduras de cobra. Aconselhado pelo Imperador, Lacerda redigiu, em 1882, em francês, uma nota ${ }^{20}$ sobre os resultados experimentais obtidos, que 'foi apresentada à Academia de Ciências de Paris, por Quatrefages'. ${ }^{21}$

Os trabalhos de fisiologia representavam uma importante área de pesquisa reforçada pelas investigações do fisiologista francês Claude Bernard (1813-1878), pesquisador do Museu de História Natural de Paris, que, sem dúvida, contribuíam para aquela pretendida projeção no cenário internacional da ciência praticada no Museu.

Em relação aos trabalhos de zoologia e botânica, é surpreendente a especificidade dos assuntos escolhidos aparentemente por critérios que não estariam respeitando as finalidades da instituição em sua missão de inventariar a fauna e flora do país e de realizar estudos aplicados, pois os 
textos nem distantemente cobriam os representantes de grandes grupos animais e vegetais.

Há estudos descrevendo as características de órgãos odoríferos situados nas pernas ou dobras existentes nas asas de certas borboletas (AMN, 1879: $37-42 ; 1878: 41-50$ ), ou ainda sobre manchas presentes nas asas de determinados insetos ( $A M N, 1879: 25-30)$, ou mesmo sobre a anatomia e a metamorfose de crustáceos (AMN, 1892: 155-175; 179-205). Os artigos de Botânica, embora raros, centraram-se na descrição de estruturas de suporte de plantas trepadeiras ( $A M N, 1876: 27-30 ; 133-144)$. Chama a atenção, no entanto, que, em todos os casos, os trabalhos tratavam de compreender a origem e a função de características adaptativas dos organismos. Essa aparente miudeza nas investigações realizadas no Museu, entre 1870 e 1890 , assume outro significado se for relacionada à afirmação de Ladislau Netto em texto de sua autoria, publicado nos Archivos, de que o Museu estava "eficazmente iniciado nas mais elevadas cogitações da filosofia evolucionista" ( $A M N, 1879: 107)$. Dessa forma, as opções temáticas, à primeira vista, tão específicas, estavam, com efeito, em perfeita sintonia com as discussões científicas que vinham ocorrendo no cenário internacional.

Trabalhos sobre estruturas de adaptação dos seres vivos, como os exemplos citados, estavam ganhando relevância no mundo científico do final do século XIX. O próprio Darwin, depois de publicar $A$ Origem das Espécies, passou a pesquisar assuntos pontuais. Bowler (1996: 128-129) ressalta que Darwin se interessava pouco por investigar os grandes temas da evolução, como o estudo dos registros fósseis, que poderia jogar luz sobre a natureza do processo evolutivo; ao contrário, preferiu 'cultivar seu próprio jardim', pesquisando características de plantas e animais que poderiam viver nos terrenos de sua casa, como vermes oligoquetas (minhocas), plantas carnívoras, plantas trepadeiras e orquídeas.

Ghiselin (1983) mostrou, contudo, que esses assuntos específicos estavam estreitamente ligados à concepção geral da evolução e constituíam exemplos de adaptações dos seres vivos. Tais investigações, na verdade, buscavam resolver uma das maiores pendências deixadas por Darwin em seu trabalho e explicar como surgiam as adaptações nos organismos. De fato, uma das primeiras publicações de Darwin, após A Origem das Espécies ter vindo a público, foi sobre plantas trepadeiras;:22 estudo no qual procurou mostrar a origem das adaptações dessas plantas que permitia a elas subir na copa de árvores mais altas para receberem luz. 
Colocados nesses termos, o sentido do programa de trabalho de Darwin, tornam-se inteligíveis determinados temas pesquisados pelos naturalistas do Museu Nacional que privilegiavam assuntos que estavam despertando o interesse dos cientistas em conseqüência das ainda recentes concepções apresentadas pelo naturalista inglês.

Outros assuntos foram abordados nos trabalhos zoológicos, como distribuição de seres vivos no espaço (biogeografia), identificação/ classificação genealógica, anatomia comparada, principalmente para estabelecer relações de afinidade entre espécies, e metamorfose de organismos. Esses temas de pesquisa, conforme observa Bowler (1992: 29), também foram estimulados pelas idéias relacionadas ao darwinismo biológico. Estudos sobre adaptação, biogeografia e especiação forneciam elementos para compreender os mecanismos de seleção natural; anatomia comparada e embriologia contribuíam para reconstruir a história da vida, ao verificar as semelhanças entre os organismos e, conseqüentemente, seu parentesco.

A análise dos conteúdos específicos dos textos revela que a identificação com os temas evolucionistas não era apenas retórica, pois os autores se referendavam em conviç̧ões evolucionistas. De fato, autores como Ladislau Netto, Fritz Müller e J. Joaquim Pizarro deixaram explícita, em seus artigos, sua identificação com as idéias evolucionistas, embora mostrassem compreensões variadas sobre as concepções de Darwin.

\section{Os estudos de Ladislau Netto}

Em 1876, Ladislau Netto publicou na revista um trabalho sobre plantas trepadeiras e, em 1878, um resumo do curso de Botânica que ministrava no Museu. Nesses textos, aceitava alguns dos pressupostos básicos das teorias de Darwin, como o fato em si da evolução - o mundo vivo é produto de um processo permanente de transformação - e a descendência dos seres vivos a partir de ancestrais comuns, ${ }^{23}$ além de utilizar concepções como 'luta pela vida' para compreender a sobrevivência de certas formas vegetais ou o desenvolvimento de outras.

Em seu estudo sobre plantas trepadeiras, advogou a tese de que tais plantas foram, no passado, arbustos vigorosos, que, habitando florestas sombrias e compactas, distenderam-se, apoiando-se em outros vegetais mais altos para alcançar a luz. Essa transformação da espécie constituía, 
para o autor, exemplo de 'adaptação cumulativa' e 'prova da luta pela vida, entre as plantas' (AMN, 1876: 133). Ao longo do texto, Ladislau Netto foi retomando o já citado trabalho de Darwin sobre o assunto, concordando com algumas de suas conclusões e contestando outras. Para ele, as gavinhas - estruturas de fixação de algumas trepadeiras que não dão a volta completa em torno do suporte, como geralmente, fazem os caules desse tipo de planta - originavam-se por "insuficiência orgânica". Darwin, diferentemente, considerava que as estruturas dessas plantas não apresentavam a circunvolução total devido a modificações sofridas secundariamente (AMN, 1876: 134).

No resumo do curso de botânica, apareceram, igualmente, várias concepções evolucionistas, dentre as quais uma referência explícita à teoria da descendência comum, ao afirmar que "a identidade de construtura que oferecem todas as células, tanto vegetais como animais, justifica no mais alto grau a perfectibilidade da doutrina evolutiva que lhes dá por fonte o reino dos protistas" ( $A M N, 1878: 193)$.

Entretanto, é preciso ressaltar que, em ambos os trabalhos, Ladislau Netto compreendia o surgimento das variações e, por conseguinte, das adaptações como resultantes unicamente de hábitos condicionados pelas circunstâncias sob as quais os organismos vivem, tal como concebido por Lamarck. ${ }^{24} \mathrm{O}$ próprio Darwin não negava essa possibilidade para explicar o surgimento das modificações, mas rejeitava a exclusividade desse fator $e$ admitia a existência de variações espontâneas devido a causas ignoradas. Já na introdução de $A$ Origem das Espécies, Darwin observou:

os naturalistas assinalam, como únicas causas possíveis para as variações, as condições exteriores, tais como o clima, a alimentação, etc. Pode ser verídico, num sentido bastante restrito, como veremos mais tarde; mas seria absurdo atribuir como únicas causas possíveis para as variações, as condições exteriores. (Darwin, s.d.: 18)

Em um trabalho posterior, que não foi publicado nos Archivos, Ladislau Netto teve oportunidade de explicitar suas concepções sobre a evolução dos organismos. Nesse texto, apresentado como conferência pública na Sociedad Científica Argentina, mencionou seus estudos sobre as trepadeiras, afirmando que "essas plantas ofereciam a mais acabada prova da seleção natural e da adaptação do indivíduo a seu meio de existência no reino vegetal" (Netto, 1882: 153). Basicamente, referia-se ao fato, já mencionado, de que as trepadeiras foram, no passado, arbustos que, "condenados a 
sucumbir sufocados pelas densas folhagens das árvores vizinhas, resistiram e deixaram filhos a quem transmitiram toda a energia de suas forças". Assim, do esforço de sucessivas gerações, os "galhos, a princípio de dois ou três metros de altura, se converteram em delgadas cordas de trinta e mais metros de extensão" (1882: 154).

Lendo essas afirmações, é plausível concluir que, para Ladislau Netto, o hábito de um ser vivo modificava sua estrutura, de modo que, com o tempo, ela se tornava muito diferente da estrutura de um outro organismo que não a tivesse utilizado da mesma maneira e, à medida que as transformações ocorriam, a seleção natural atuava, selecionando, assim, as variações surgidas do esforço dos indivíduos em se adaptarem ao ambiente. Tal interpretação não inclui a idéia de Darwin (s.d.: 131), que aparece em $A$ Origem das Espécies, segundo a qual a seleção também atua sobre variações que não resultaram da necessidade de o organismo se adaptar ao meio e, portanto, não são devidas a causas exteriores, mas originárias de causas ignoradas. Nesse particular, Ladislau Netto se aproximava de Haeckel, para quem os fatores lamarquistas eram a força geradora da variação que, apesar de ser adaptativa para o indivíduo, passaria pelo teste da seleção natural quando o organismo entrasse em competição com outras espécies.

É interessante observar que as posições assumidas por Netto para interpretar os fenômenos biológicos, dando relevância ao estímulo ambiental como causa das transformações dos seres vivos, reapareceram quando ele se manifestou quanto à evolução da humanidade. A mesma lógica que regia a organização do mundo vegetal e animal, no entender de Ladislau Netto, orientava a natureza humana. Assim, ele traçou um paralelismo, afirmando que "as lutas e paixões da humanidade, as ambições insaciáveis e os sentimentos eternos de vingança têm seus simulacros tanto no fundo do Oceano, como no seio das florestas, nos areais ardentes do deserto e nas ermas regiões da cordilheira" (Netto, 1882: 157).

Ladislau Netto encerrou sua conferência, apontando os fatores (externos) que considerava eficazes para modificar o ser humano e distanciálo, cada vez mais, dos organismos primitivos aos quais estava ligado pela origem: "ante estes exemplos ensinadores da natureza, procuremos, senhores, por meio da cultura da inteligência e pelo mais amplo desenvolvimento das leis sociológicas, romper as cadeias que nos escravizam ao resto da criação" (1882: 158). 
Notável, por fim, é verificar, ainda nesses escritos, o esforço de Ladislau Netto para não dissociar o pensamento evolucionista do religioso. Já no início da conferência, afirmou ser verdade que homens eminentes em ciências exatas, doutrinas políticas e sociais, radicados ainda na filosofia escolástica, perguntavam-se 'cheios de pavor' se as teorias evolucionistas não seriam 'um cataclismo em que submergiriam as crenças religiosas'. Aos que assim pensavam, pediu que ficassem tranqüilos, pois

a nova doutrina, de verdadeira e sedutora que é, antes de vencer, convence. Conquistadora da razão, ela oferece, pela maneira rápida com que se assimila no seio da sociedade, a mais eloqüente prova de sua perfeição (...) sem pretender provocar conflitos na órbita da religião (...), antes, ao contrário, submetendo-se a seu irresistível domínio. (1882: 148)

Em trabalho de 1878 , anterior, portanto, à publicação dessa conferência, já aparecia a idéia de um Criador orientando o processo de transformação da vida. Nessa oportunidade, Ladislau Netto, depois de citar alguns exemplos de vegetais com adaptações ao frio intenso, ao ambiente aquático, afirmou: "os vegetais armados deste modo pela natureza para a luta pela vida são os Alexandres e os Napoleões do mundo vegetativo; deulhes o Criador toda a energia dos conquistadores e não há de cortar-lhes o passo" (AMN, 1878: 198). Ele procurava, assim, conciliar ciência e religião, ao não renunciar à crença de um Criador dirigindo o processo evolutivo.

\section{As publicações de Fritz Müller}

Os trabalhos de Fritz Müller, ${ }^{25}$ naturalista viajante do Museu Nacional no período de 1876 a 1891, seguiram uma outra direção, e como é de amplo conhecimento, constituíram um autêntico breviário das teses darwinistas, fato reconhecido pelo próprio Darwin, com quem manteve correspondência desde 1865 até a morte do naturalista inglês. Segundo Francis Darwin, essa correspondência foi uma fonte de prazer para seu pai; tinha até a impressão de que, de todos os amigos que seu pai não chegou a conhecer pessoalmente, Fritz Müller foi aquele por quem tinha o maior apreço (Darwin, 1958).

Diferentemente do diretor do Museu, Müller trabalhava com a idéia de que as variações poderiam surgir por causas desconhecidas e, por essa razão, era mais fiel aos preceitos de Darwin. Desde seu famoso trabalho Für Darwin, ${ }^{26}$ suas convicções já estavam claras. Nesse texto, detalhou 
vários aspectos sobre a biologia de crustáceos. Ao estudar as diferenças entre machos e fêmeas de várias espécies, ${ }^{27}$ verificou que nos apêndices locomotores das fêmeas de algumas dessas espécies desenvolvia-se uma estrutura que facilitava o aprisionamento delas pelo macho, durante o 'ato amoroso'. Como essa estrutura estava presente em algumas poucas espécies, Müller sugeriu que ela tivesse aparecido por acaso e, por ser útil, fora selecionada. Argumentou que

sua presença terá de ser encarada não como obra de premeditado desejo, mas como a de um acidente tornado uso pela seleção natural. E, concluiu, 'não podemos perceber porque o Criador muniu só estas poucas espécies de um aparelho que ele julgou inteiramente compativel com o 'plano geral de estrutura' dos Amphipoda e, entretanto, recusou-o aos outros que vivem sob as mesmas condições externas e os igualam, ainda, na extraordinária lascívia'. (1990: 20-21)

Nessa mesma obra, estudando o desenvolvimento embrionário dos crustáceos superiores, verificou a presença de um determinado tipo de larva, até então considerada inexistente nesses crustáceos. Isto contribuiu para dar expressão à idéia de que o embrião, ao se desenvolver, passava pelas mesmas transformações sofridas pela espécie no correr dos tempos, generalizada por Müller como 'lei de recapitulação'.

Retomada por Haeckel, tal idéia foi elaborada como lei biogenética fundamental ou da recapitulação filogenética. ${ }^{28}$ Essa lei biológica, sem dúvida, foi uma das mais populares não só entre os biólogos do século XIX. Darwin, em sua autobiografia, lamentou o fato de ter perdido a precedência dessa formulação que se tornou tão conhecida e aceita naquele momento e sobre a qual afirmava ser de sua autoria, embora reconhecesse não ter conseguido 'impressionar' seus leitores. ${ }^{29}$

É fato, portanto, que Müller, quando começou a trabalhar no Museu Nacional, em 1876, já era divulgador das idéias de Darwin, reconhecido internacionalmente havia mais de dez anos, desde a publicação de Für Darwin em 1864, na Alemanha, e em 1869, na Inglaterra, editada por sugestão do próprio Darwin. Esse traço do currículo do cientista, aliás, foi destacado por Ladislau Netto no ofício endereçado ao ministro, solicitando autorização para contratá-lo:

O Dr. Frederico Müller que tão relevantes serviços há prestado à ciência e que tão alta graduação ocupa atualmente no mundo científico pelos seus descobrimentos, em grande parte publicados em colaboração com o ilustre precursor Carlos Darwin, (...) como o provam os impressos que de ambos possuo. ${ }^{30}$ 
Durante os anos em que trabalhou no Museu, publicou, na revista Archivos, quinze trabalhos (dez sobre insetos e cinco sobre crustáceos). ${ }^{31}$ A análise desses textos revela a diversificação de seus interesses: estudos de classificação, anatomia, fisiologia e desenvolvimento animal; revela também sua preocupação em apresentar evidências da seleção natural. Müller realizou estudos que buscaram estabelecer o significado de estruturas, aparentemente sem função, numa tentativa de poder reconhecêlas como vestigiais e, desse modo, mostrá-las como prova de parentesco com outros organismos e, portanto, como prova de evolução desses seres. Procurou identificar estruturas análogas que, por desempenharem funções semelhantes em indivíduos de espécies diferentes, também poderiam representar prova de evolução (convergência adaptativa) (32 $^{32}$ ou mais especificamente da seleção natural.

Como seus trabalhos constituem a maior parte das publicações de zoologia, pois é o autor de quem foi reproduzido o maior número de artigos, suas idéias acabaram por marcar fortemente a linha editorial dos Archivos.

Outros estudos de Müller, que não foram publicados na revista do Museu, tiveram importância capital para o evolucionismo, pois trataram de fatos biológicos considerados exemplos de mudanças evolutivas decorrentes da seleção natural. Este estudioso descreveu casos em que espécies diferentes de borboletas, todas com gosto desagradável para aves insetívoras, suas predadoras, exibiam o mesmo padrão de coloração, tornando-se muito semelhantes umas às outras, apesar da inexistência de parentesco. Por seleção natural, convergiam na aparência, e todas ficavam protegidas dos predadores, que, por sua vez, aprendiam a evitar insetos com aquele tipo de coloração. Esse fenômeno tornou-se conhecido como mimetismo mülleriano.

O naturalista viajante do Museu teve sua obra extensamente divulgada na Europa, tornou-se um dos maiores defensores de Darwin e um dos poucos apontados na literatura sobre o darwinismo ${ }^{33}$ como adeptos da teoria sobre a seleção natural. Sua perspectiva teórica, no que diz respeito à compreensão sobre como surgiam as variações, não reaparece nas obras de seus colegas no Museu. Já a idéia de recapitulação durante o desenvolvimento embrionário, sobretudo na versão apresentada por Haeckel, foi inteiramente absorvida pelos zoólogos; em particular, Alípio de Miranda Ribeiro, que integrou o quadro do pessoal do Museu Nacional desde 1894. 


\section{Os trabalhos de João Joaquim Pizarro e de outros naturalistas}

João Joaquim Pizarro, médico, diretor da seção de zoologia do Museu entre 1871 e 1883, era, segundo Lacerda (1905: 60), "um transformista radical e exagerado", que, com suas palestras, escandalizou, mais de uma vez, o auditório feminino durante os cursos do Museu, ao tratar da descendência do homem, frisando os pontos comuns que o ser humano mantinha com os "macacos".

Há um único artigo desse autor publicado em Archivos, no ano de 1876, que recebeu de Mello Leitão (1937: 236) comentário desabonador, ao sugerir que teria sido melhor se o texto tivesse ficado guardado 'entre papéis esquecidos'. Trata-se do estudo de um animal que, segundo o diretor da seção de zoologia, assemelhava-se "a um sapo no terço superior de seu corpo e à peixe nos dois terços posteriores" (AMN, 1876: 32).

Nesse trabalho, dedicado aos "professores Darwin, Haeckel e Charles Martins", o autor declarou sua adesão ao evolucionismo, já na abertura do trabalho, ao relacionar o desenvolvimento das ciências naturais no Brasil à obra de Darwin. Na sua avaliação,

o bom caminho e o progressivo desenvolvimento que começa a ter no Brasil o estudo das ciências naturais, graças à paternal solicitude do seu Imperante, pode-se dizer que é em boa parte devido ao impulso grandioso que ao movimento científico deste país deu o gênio de Darwin com a publicação do seu trabalho sobre a origem das espécies. Verdadeiro monumento de paciência e de gênio veio este livro despertar a atenção dos povos do continente sulamericano cujos filhos pareciam dormir o sono da indiferença sobre o mundo de preciosidades que entesouram as suas terras. (AMN, 1876: 31-32)

Pizarro deixou claro que não fora possível realizar "um estudo sério e minucioso" porque só possuía um exemplar que não poderia dissecar, razão pela qual apenas iria apresentar uma sucinta descrição. Tal descrição, no entanto, foi acompanhada de várias observações com o propósito de mostrar que o espécime analisado poderia ser "uma forma transitória", um intermediário entre dois grupos, ou, em suas palavras, "um animal, que, como alguns outros, apresentam características de classes distintas e que constituem prados como argumentos de grande valor pelos sectários da doutrina evolutiva" (AMN, 1876: 35). 
Encontrar seres vivos que representassem formas de transição entre dois grandes grupos tornou-se um dos muitos programas de trabalho científico estimulados pelas idéias evolucionistas. A existência de organismos intermediários poderia constituir provas do processo evolutivo em ação, evidências de que teria havido um ancestral comum. As pesquisas do embriologista russo Alexander Kowalevsky, iniciadas na década de 60 , tiveram grande impacto sobre os pesquisadores da época, pois mostraram que animais como a ascídia, considerada, até então, um invertebrado (molusco), apresentava uma estrutura - a notocorda - característica de animais superiores (os cordados). ${ }^{34}$

O trabalho de Kowalevsky fortaleceu as idéias de Haeckel e Müller de que o desenvolvimento do ser recapitulava os estágios de desenvolvimento de seus ancestrais (Montgomery, 1988), uma vez que se tratava de um animal cordado que mantinha características de um invertebrado. Ao mesmo tempo, estimulou os pesquisadores a procurarem outros organismos intermediários; Haeckel foi um dos maiores entusiastas dessa linha de investigação.

Considerando as expectativas daquele momento, Pizarro, ansioso por oferecer uma contribuição original que pudesse constituir, conforme suas próprias palavras, "argumentos de grande valor pelos sectários da doutrina evolutiva", talvez tenha se apressado em descrever um animal que mal estudou, e concluído que estava diante de uma "forma transitória" (AMN, 1876: 34). Contudo, as ilustrações que acompanham o artigo parecem indicar que se trata de uma larva de anfíbio em processo de metamorfose e não de um animal intermediário entre peixes e anfíbios. $\mathrm{O}$ autor chegou a considerar, no próprio texto, a possibilidade de ser, de fato, uma larva, mas a descartou, sob o argumento de que, na metamorfose de um autêntico girino, a cauda desaparecia à medida que as patas surgissem, o que, na sua avaliação, não estava ocorrendo com o exemplar em estudo.

Miranda Ribeiro (1945), em conferência datada de 1916, criticou duramente Ladislau Netto por atrair "o ridículo sobre o Museu, publicando cincadas colegiais no seu órgão de 'propagação dos estudos e conhecimentos das ciências". Uma dessas 'cincadas' era justamente o artigo de Pizarro que, no dizer de Ribeiro, tornou-se "célebre" e motivo de "sorrisos sublinhados" entre estrangeiros (Ribeiro, 1876: 48). De toda forma, o trabalho de Pizarro revela a adesão quase incondicional de certos pesquisadores do Brasil ao debate evolucionista travado no final do século. 
Outros autores que publicaram trabalhos na área de zoologia e botânica nesse período foram Nicolau Moreira e Hermann von Ihering. Emílio Goeldi ${ }^{35}$ publicou apenas um extenso relatório descrevendo sua investigação e apontando algumas conclusões sobre a moléstia do cafeeiro que estava dizimando as culturas desse produto na região fluminense.

Nicolau Moreira, vinculado à seção botânica do Museu desde 1872, de onde saiu apenas em 1883, publicou um único artigo, curiosamente, sobre insetos, no volume IV da revista, editada em $1881 .{ }^{36}$ Trata-se de um estudo essencialmente descritivo das características morfológicas das fases larvais de uma determinada borboleta. É digno de nota um questionamento que fez sobre a origem da cor dourada que caracterizava a larva que estudou; ele levantou a hipótese de que o meio, no caso a alimentação, poderia influir na determinação da cor, afirmando que "não seria desarrazoado aceitar esta hipótese à vista dos conhecimentos adquiridos sobre a influência que exercem, na morfologia, as diversas condições de existência em que se acham os animais e vegetais" ( $A M N, 1881: 10)$. Esse posicionamento de valorizar a interferência do meio na determinação das características dos seres vivos talvez o aproxime mais das conviç̧ões de Ladislau Netto do que das de Müller, em relação às explicações sobre como surgem as variações.

Hermann von Ihering, ${ }^{37}$ naturalista viajante do Museu entre $1883 \mathrm{e}$ 1891, estudava os moluscos da América do Sul. Sua contribuição nos Archivos resume-se a um único trabalho, publicado em 1892, quando já estava fora dos quadros da instituição. Nesse detalhado estudo de um certo tipo de molusco, é perceptível sua orientação evolucionista ao deixar claro que seu objetivo era discutir a posição sistemática do animal a partir de estudos anatômicos que visavam a estabelecer os laços orgânicos, as afinidades que o tal animal mantinha com outros representantes e, assim, contribuir para a construção da genealogia do grupo.

Esses vários artigos de zoologia e botânica, publicados na revista do Museu, no período entre 1876 e 1892, revelam que seus autores incorporaram, diferentemente, o ideário do darwinismo biológico, ao descreverem e interpretarem os fenômenos estudados. A idéia de seleção natural, combinada ou não com a presença de um Criador dirigindo o processo evolutivo, assim como compreensões variadas sobre como surgiam as adaptações nos organismos, nortearam as pesquisas publicadas, e espelham, na verdade, o ecletismo que dominou as discussões evolucionistas nas três décadas que se seguiram à publicação de A Origem das Espécies, como será discutido posteriormente. 
Além disso, analisado o conjunto das publicações, nessas áreas de conhecimento, ficou patente que os assuntos predominantes nas páginas da revista representavam questões significativas para o debate que vinha ocorrendo no interior das ciências naturais sacudidas pelo evolucionismo pós-Darwin. Chama a atenção o fato de que estudos aplicados, cujos conteúdos estavam voltados para questões locais, como os problemas agrícolas brasileiros, não tenham sido temas freqüentes na revista do Museu. A produção de Nicolau Moreira, por exemplo, dirigida para questões práticas, citada anteriormente, não foi publicada nos Archivos, mas em periódicos especializados como Revista Agrícola ou $O$ Auxiliador. ${ }^{38}$

Essa característica parece se coadunar com o projeto editorial da revista, anunciada por Ladislau Netto, de fazer dos Archivos um meio para revelar aos 'países estranhos' o 'nosso avanço no estádio da civilização'. Isto significou fazer escolhas, privilegiando, nos conteúdos relacionados à zoologia e à botânica, assuntos sintonizados com o movimento científico que vinha dominando as ciências naturais naquele momento.

\section{Os Propósitos do Museu e a Produção Científica nas Primeiras Décadas da República}

Às vésperas da República, o Museu foi reorganizado nos termos do Regulamento de $1888 .{ }^{39}$ Em essência, houve mudança na organização das seções, que, conforme observa Lopes (1997: 159-160), longe de constituir medida burocrática, refletia as mudanças nas concepções científicas da época, representando um ajuste às novas especialidades que se constituíam e ganhavam espaços no Museu como a antropologia, a paleontologia e a embriologia.

Com efeito, as três especialidades estavam diretamente relacionadas com o desenvolvimento das teorias darwinistas. Bowler (1992: 29) sustenta que o evolucionismo darwinista contribuiu para a expansão de várias áreas de pesquisa que poderiam ser agrupadas em duas grandes categorias: a que envolvia os estudos de adaptação, distribuição geográfica e especiação, campos explorados sobretudo pelos naturalistas, e a que se referia à reconstrução da história da vida por meio de evidências e provas fornecidas pela paleontologia, anatomia e embriologia. Os estudos antropológicos e arqueológicos, particularmente os de antropologia física, também se 
expandiram com o darwinismo, porque, conforme já foi apontado anteriormente, dentre outras razões, despertava interesse o estabelecimento das origens dos diferentes povos.

Uma outra mudança significativa foi a substituição dos cursos públicos por conferências públicas. De acordo com o novo regulamento, o Museu, a partir daquela data, passaria a ministrar sempre que fosse conveniente aos interesses da instituição e da ciência "conferências públicas sobre os assuntos concernentes à especialidade de cada seção". ${ }^{40}$

A intenção dessa mudança já havia sido registrada em relatório do diretor, datado de 1886, dirigido ao ministro da Agricultura, no qual apresentava uma avaliação negativa sobre os cursos públicos que tanto defendera em anos anteriores. Ladislau Netto afirmou que os cursos públicos eram, "de todos os ramos de serviço do Museu, o menos útil e o mais dispensável, quer para o proveito desta repartição, quer em benefício do público". Continuando sua argumentação, deixou entrever que os cursos não tiveram a freqüência esperada, ao observar que "o país não tem ainda o paladar preparado para estes apreendimentos cotidianos, não obrigados por matrícula ou por inscrição regulamentar adstrita a exames do respectivo aproveitamento no fim do ano escolar". Na conclusão de suas considerações, deixou claro que o assunto, "na próxima reforma do Museu Nacional", poderia ser "estudado com aplicação à natureza e às circunstâncias desta instituição". ${ }^{41} \mathrm{Em}$ sua avaliação, obviamente, não chegou a cogitar a possibilidade de que os cursos pudessem ter sido desinteressantes ao público para o qual eram dirigidos que, aliás, era bastante diversificado. ${ }^{42}$

Não foi, por acaso, então, que essa reforma retirou dos propósitos da instituição a função de 'ensino das ciências físicas e naturais', que constava do Regulamento de $1876,{ }^{43}$ mantendo apenas o objetivo de "o estudo da História Natural, particularmente do Brasil, cujas produções deverá coligir e conservar sob sua guarda, devidamente classificadas de modo a serem expostas ao público" (Regulamento de 1888: 523).

Com o advento da República, duas outras reformas, que introduziram várias modificações administrativas, ocorreram ainda sob a administração de Ladislau Netto, dentre as quais, a obrigatoriedade da assinatura diária do ponto, que provocou a demissão dos naturalistas viajantes Fritz Müller e Hermann von thering em episódio desgastante, sobretudo para o diretor. ${ }^{44}$

Em relação às finalidades da instituição, permaneciam, basicamente, as mesmas, exceto a abrangência dos estudos de história natural que 
deveriam se tornar extensivos ao globo, com especial atenção ao Brasil. Lopes (1997: 162) avalia essa mudança como expressão do reforço de um modelo de museu metropolitano e universal, modelo este, considerado a vocação da instituição.

Efetivamente, a divisão em quatro grandes seções, abrangendo várias áreas de conhecimento; a organização de coleções, que não se restringiam a representantes da natureza do Brasil; ${ }^{45}$ e o desenvolvimento de pesquisas, várias das quais sobre temas similares aos dos grandes museus europeus, apontam para esse modelo que, em linhas gerais, assim permaneceu por quase toda a administração seguinte à de Ladislau Netto. ${ }^{46}$ Havia, no entanto, no interior da própria instituição, críticas a essa organização. Alípio de Miranda Ribeiro, da seção de zoologia, julgava-a anacrônica em texto escrito em 1916; na sua avaliação, não havia razão para sustentar um "museu complexo", em uma época do "domínio da especialidade" e propôs a dissociação "dos quatro museus concentrados nesta casa" (Ribeiro, 1945: 61), referindo-se às seções de geologia, botânica, zoologia e antropologia.

Os anos iniciais da República foram, para o Museu, um período bastante tumultuado não só pela saída de vários pesquisadores, mas também pela saída definitiva do próprio Ladislau Netto, em dezembro de 1893. Para substituí-lo, foi nomeado Domingos José Freire, professor aposentado de Química da Faculdade de Medicina do Rio de Janeiro, que permaneceu no cargo até janeiro de 1895.

Freire, bacteriologista, destacou-se, no final do século XIX, por ter descrito o micróbio que julgava ser o causador da febre amarela e desenvolvido uma vacina com a qual acreditava poder combatê-la. ${ }^{47}$ Dirigindo o Museu por curto período, não publicou nenhum trabalho nos Archivos e recebeu, de seu sucessor no cargo, a dura crítica de que "durante o tempo em que esteve em exercício, limitou a sua tarefa a assinar o expediente" (Lacerda, 1905: 68).

Lacerda assumiu em 1895 e dirigiu a instituição durante mais de 20 anos, até agosto de 1915. Nessa administração, também aconteceram várias mudanças; é bastante nítida a orientação crescentemente voltada para atividades experimentais, representada pela instalação de laboratórios, como resposta às exigências de estudos aplicados que cresceram, sobretudo, no início do século, dirigidos para as questões de saúde e higiene da população ou mesmo as pragas agrícolas.

Lacerda deixou explícito o valor que atribuía aos estudos experimentais e aplicados, ao afirmar que 
modernamente a missão dos museus não está reduzida, como outrora, a ser um simples repositório de objetos interessantes expostos às vistas do público, que nem sempre sabe tirar reais vantagens para a sua instrução, de um exame perfunctório de tais objetos. O seu campo de ação é mais amplo, por isso que nele se inclui hoje a parte investigável da ciência, a pesquisa experimental, exercitada ao lado da sistematização, da coordenação e da classificação dos espécimes naturais e das coleções. Não se conhece hoje um bom museu de história natural que não tenha laboratórios, e onde não se estudem questões de biologia com todos os recursos técnicos da ciência moderna. (1905: 72)

Durante os anos da administração Lacerda, em harmonia com os preceitos preconizados por ele, foram instalados o Laboratório de biologia, especializado em bacteriologia; de química vegetal; de entomologia e de fitopatologia, destinados a tratar dos problemas da produção agrícola; e o de química geral, dedicado à análise de adubos, terras, rochas e minerais. Todos, portanto, diretamente relacionados com questões de interesse econômico.

Nesse período, foram publicados nove volumes da revista Archivos, contendo 50 trabalhos das mesmas áreas de conhecimento, já constantes nas publicações anteriores, exceto pela inclusão de alguns artigos referentes à bacteriologia, como se pode constatar na Tabela 2 .

Tabela 2 - Número de trabalhos publicados nos $A M N$, por tema e por volume.

$$
\text { Brasil - 1895-1915 }
$$

\begin{tabular}{l|c|c|c|c|c|c|c|c|c}
\hline $\begin{array}{l}\text { Vol./Área de } \\
\text { conhecimento }\end{array}$ & $\begin{array}{c}\text { IX } \\
(1876)\end{array}$ & $\begin{array}{c}\text { X } \\
(1879)\end{array}$ & $\begin{array}{c}\text { XI } \\
(1878)\end{array}$ & $\begin{array}{c}\text { XII } \\
(1876)\end{array}$ & $\begin{array}{c}\text { XIII } \\
(1876)\end{array}$ & $\begin{array}{c}\text { XIV } \\
(1876)\end{array}$ & $\begin{array}{c}\text { XV } \\
(1876)\end{array}$ & $\begin{array}{c}\text { XVI } \\
(1876)\end{array}$ & TotAL \\
\hline Zoologia & & & 04 & 03 & & & & 05 & $19(34 \%)$ \\
\hline Fisiologia & 01 & 02 & 02 & 01 & & & & & $06(11 \%)$ \\
\hline Arqueologia & 04 & 04 & & & & 01 & & & $09(16 \%)$ \\
\hline Paleontologia & & & & & & & 01 & & $01(2 \%)$ \\
\hline Botânica & 01 & & & & 01 & & & & $02(4 \%)$ \\
\hline Geologia & & 01 & 04 & 02 & & & & & $07(12 \%)$ \\
\hline Antropologia & 02 & & & 02 & & 03 & & & $07(12 \%)$ \\
\hline Outros* & & 01 & 01 & & & & & 03 & $05(9 \%)$ \\
\hline TotaL & 10 & 13 & 11 & 08 & 01 & 04 & 01 & 08 & 56 \\
\hline
\end{tabular}

* Incluem-se nessa categoria, os editoriais, prefácios, necrológios e relatórios. 
A análise global dos assuntos tratados revela que a metade dos trabalhos concentrou-se na área zoológica, com estudos da fauna brasileira; a outra metade distribuiu-se pelos demais temas, com poucos artigos em cada um deles. Há pesquisas sobre fósseis, flora, cultura indígena, formações geológicas e doenças, todas referentes ao Brasil.

Alguns deslocamentos de interesse podem ser observados, quando se compara, nas Tabelas 1 e 2, a freqüência de estudos em determinadas áreas nos dois períodos. $\mathrm{Na}$ administração Ladislau Netto, os trabalhos de antropologia, arqueologia, geologia e fisiologia somados representavam cerca de $50 \%$ do total das publicações. Na administração Lacerda, essa cifra baixou para $18 \%$.

Em parte, essa alteração pode ser justificada pela mudança de interesse do próprio Lacerda, que passou a privilegiar a bacteriologia em suas pesquisas. Nesse período, o novo diretor do Museu publicou quatro trabalhos sobre esse tema, referentes à febre amarela e ao beribéri, dois de fisiologia e nenhum de antropologia. Lacerda foi um dos que mais contribuiu com publicações nessas duas últimas áreas, nos anos anteriores. Dos sete trabalhos relacionados à antropologia, publicados entre 1876-1892, quatro são de sua autoria, além do resumo do curso de antropologia e todos os seis de fisiologia. ${ }^{48}$

Vários dos assuntos investigados nessa fase eram similares aos desenvolvidos por grandes Museus de História Natural europeus, não por simples coincidência, mas como parte do programa de trabalho estabelecido por Lacerda. Como ele próprio levantou, no Museu de Paris, Claude Bernard trabalhou com fisiologia vegetal e animal e pesquisou a ação de substâncias venenosas, como o curare; mais recentemente, assinalava, Physalix e Bertrand estavam estudando a natureza e a ação dos venenos de cobras. No Museu Britânico, lembrou, foram realizados estudos de fisiologia e histologia de peixes elétricos, animais fosforescentes e plantas carnívoras, e estavam sendo iniciados estudos sobre a biologia do mosquito. Com essa síntese, concluiu serem esses temas "parte integrante e essencial do programa dos museus mais bem organizados do mundo", e o Museu do Rio de Janeiro não deveria constituir "exceção a essa regra" (Lacerda, 1905: 72).

De fato, alguns assuntos citados reaparecem nas publicações dos Archivos, como os estudos de fisiologia sobre o curare e plantas venenosas; estudos das adaptações de plantas carnívoras e alguns trabalhos descritivos sobre dípteros parasitas, ordem de insetos que reúne moscas e mosquitos, transmissores de diversas doenças. ${ }^{49}$ 
Em relação à bacteriologia, como é de amplo conhecimento, no início do século XX no Brasil, os conteúdos dessa área eram requeridos para fundamentar e implementar as propostas de modernização dos centros urbanos, que previam, entre outros aspectos, o combate às epidemias. $\mathrm{O}$ Museu se envolveu, ainda que timidamente, em pesquisas sobre a febre amarela, tentando identificar seu agente causador.

Lacerda publicou três estudos, ${ }^{50}$ todos com base em atividades de observação e experimento, nos quais descreveu um micróbio associado à doença, diferente do que foi encontrado por Domingos Freire. Identificou-o como o agente causador da febre amarela e, desse modo, tanto quanto Freire, contrariou as conclusões, elaboradas pela Comissão Americana em Havana (1900) e pela Comissão Francesa no Rio de Janeiro (19011905), de que o micróbio da febre amarela não era visível com os recursos de que dispunham. Lacerda publicou ainda um outro trabalho ${ }^{51} \mathrm{em}$ que apresentou suas observações sobre o microrganismo que identificou como responsável pelo beribéri.

O paradigma da 'era pasteuriana', de acordo com o qual as doenças eram, em geral, causadas por um agente biológico, dominava o meio científico naquele momento, e Lacerda, como a maioria dos pesquisadores da época, passou a procurar e 'encontrou' os microrganismos que estariam, respectivamente, causando a febre amarela e o beribéri.

Em ambos os casos, o diretor do Museu Nacional estava convicto de que a primazia da descoberta do agente causador lhe seria em breve atribuída. No final de seu trabalho, em que julgou ter definitivamente descrito o agente causador da febre amarela, Lacerda declarou:

O micróbio da febre amarela está finalmente descoberto.

E se porventura deve resultar daí uma glória para o país da América em que essa importante descoberta realizou-se, essa glória ninguém poderá doravante disputar ao Brasil. (AMN, 1909: 214)

Em relação ao beribéri, afirmação semelhante constou do final do trabalho, embora a conviç̧ão sobre o acerto de seu achado ainda não estivesse tão consolidada. Deixou registrada sua expectativa:

Se, como espero, depois de divulgada em outros centros científicos a descoberta feita agora no Brasil for ela por outros pesquisadores confirmada, a glória desse fato caberá ao nosso país e dela muito naturalmente comparticipará esta ilustre Associação de médicos, cujos esforços tenham convergido para o mesmo fim. (AMN, 1909: 250) 
Trabalhos posteriores, no entanto, mostraram que os organismos, descritos por Lacerda, não tinham relação com as doenças. A febre amarela, por ser provocada por um vírus, de fato não poderia ter seu agente visualizado com as técnicas disponíveis na época, e o beribéri, doença decorrente da falta de vitamina $\mathrm{B}_{1}$ no indivíduo, não está associado a nenhum tipo de microrganismo.

Benchimol (1999), no entanto, chama atenção para a particularidade das conviç̧ões de Lacerda que insistia no caráter polimórfico do germe responsável pela febre amarela, isto é, que o micróbio se apresentava sob diferentes formas, dependendo da fase de vida em que se encontrava e do ambiente. O polimorfismo do germe associado à febre amarela era o principal argumento de Lacerda para contraditar as conclusões das comissões que proclamavam a invisibilidade desse micróbio. No sangue, informava o pesquisador do museu Nacional, a "forma de tórula" era pouco visível; já no fígado, quando assumia a "forma de células redondas", com "brilho opalino", era perfeitamente observável (AMN, 1907: 7-8).

As concepções sobre a fluidez das formas microbianas tiveram seu auge entre 1865 e 1875 , lembra Benchimol, mas mantiveram sua relevância "como objeto de pesquisa, associado às idéias darwinistas e aos estudos de hereditariedade que começaram a ganhar vulto em fins do século XIX" (1999: 195, 197).

O polimorfismo, no limite, significava uma espécie de organismo se transformando em outro, já que os defensores dessa propriedade dos seres vivos admitiam que fermentos e bactérias se alternavam na forma, ou seja, certos fungos podiam aparecer como bactérias, por exemplo. O meio era determinante para favorecer o surgimento de uma ou outra forma. No caso da febre amarela, o micróbio variava sua forma, caso o meio fosse líquido (sangue) ou sólido (tecidos).

Benchimol adverte, com justeza, que o alinhamento de Lacerda com o polimorfismo, que o levou a acreditar que determinado fungo seria o causador da febre amarela, é expressão de seu antifixismo. Na sua avaliação, o diretor do Museu Nacional "teve atuação marcante nas duas vertentes do antifixismo, aquela que dissolvia fronteiras taxionômicas no mundo microscópico, e a que sopesava os efeitos da interação das raças no mundo macroscópico" (1999: 199).

A raiz desse antifixismo de Lacerda no que diz respeito aos fatos biológicos parece estar na sua identificação com os preceitos teóricos de 
Claude Bernard, de quem era, conforme suas próprias palavras, "um fanático admirador", e dizia estar "sempre disposto a ouvir os seus conselhos e a pôr em prática os seus preceitos". Declarava ainda, sem inibição: "foi ele que me guiou os passos vacilantes nos meus primeiros ensaios sobre a febre amarela, e é ainda ele que fortalece o meu espírito e ilumina o meu entendimento neste debate" ( $A M N, 1909: 203)$. A interpretação do diretor do Museu, de que os micróbios da febre amarela tinham forma cambiante, dependendo do meio em que se encontravam, era perfeitamente compatível com a perspectiva de Claude Bernard de que o organismo interagia com o meio, e o tipo de interação dependia do nível de organização do ser vivo.

A fisiologia bernardiana, por sua vez, na visão de Conry (1974: 370), facilitou o encaminhamento do evolucionismo na França, para a vertente lamarquista que via o organismo como um sistema integrado capaz de se auto-ajustar às oscilações do meio. Lacerda estava, sem dúvida, próximo dessa conviç̧ão.

Os estudos de Lacerda sobre o curare e plantas venenosas seguiram, conforme suas palavras, "estritamente as linhas que em estudos semelhantes traçaram Bernard e Vulpian, os dois grandes mestres da Fisiologia dos venenos". Com isto, estava querendo dizer que combinava o "método experimental" com a "lógica da indução" ( $A M N, 1909:$ V).

$\mathrm{Na}$ publicação sobre as plantas venenosas, além de discutir o papel dos venenos sobre as células dos organismos, Lacerda reservou um espaço para tecer considerações sobre como imaginava ser o processo de criação dos sábios (os cientistas). "A ciência", argumentou, "são as idéias"; "o fato ou o fenômeno não passa de uma impressão recebida pelos nossos sentidos e apreciada pelo nosso entendimento" (AMN, 1909: 12). Essa qualidade de poder compreender as 'coisas criadas' era atribuída, no entanto, a Deus. Darwin é citado como exemplo de "homem dotado pelo Criador de faculdades de análise e de generalização extraordinárias" ( $A M N, 1909: 11)$. Nessa menção a Darwin, Lacerda o descreveu como tendo sido aquele que

empreendeu a mais vasta síntese, que até hoje, a inteligência humana conseguiu realizar: a síntese da criação no grande reino dos animais. Ele desenrolou a cadeia da sucessão das espécies, durante um lapso de tempo incalculável, preenchendo as lacunas que a ação do tempo havia nelas produzido, e assim mostrou os pontos de ligação do homem com toda a série animal. ( $A M N, 1909: 11)$ 
Nesse parágrafo, Lacerda, parece aceitar a incorporação do ser humano na cadeia evolutiva do reino animal. Em seu texto, publicado em 1905, deixava explícito que "a hipótese da origem simiana do homem" tinha "a seu favor numerosos fatos anatômicos e embriológicos", mas, ao mesmo tempo, contrapunha que "nem esses fatos, por mais sugestivos que eles pareçam, nem as considerações de outra ordem, que se tem querido fazer valer na comprovação dessa hipótese, esclarecem as dúvidas que a tal respeito atormentam o espírito de muitos zoólogos" (Lacerda, 1905: 93-94).

A forma de apreciar essa concepção darwinista é coerente com seu modo de compreender a ciência, que só poderia ser a "ciência concreta, dos fatos provados e das demonstrações experimentais", e, por isso mesmo, limitada em seu alcance ( $A M N, 1909: 12)$. Ainda no texto sobre as plantas venenosas, afirmava,

as causas primeiras, inacessíveis aos nossos meios de investigação, estão fora da órbita da ciência (...) a interrogação porque, referindo-se à razão primeira das coisas, é uma palavra surda-muda, que nada pode dizer nem ensinar. Como, de que modo, ou por que forma, eis a única-interrogação que à ciência é permitido fazer, analisando os fatos. (AMN, 1909: 13 - Grifos do autor)

Também nesse aspecto, Lacerda se aproximava de seu mestre Claude Bernard que, de modo semelhante, assim se posicionava: "eu ignoro as causas finais porque eu ignoro a causa inicial (...) eu me privo de ambas" (Bernard apud Stebbins, 1988: 135).

Atendo-me aos trabalhos de zoologia e botânica, constatei que o Museu Nacional, além dos assuntos que constavam dos programas de pesquisa de grandes museus internacionais, investigou também alguns outros como a biologia de crustáceos; vermes oligoquetas (as minhocas); peixes e plantas ornamentais (as orquídeas). É interessante lembrar que vermes oligoquetas, orquídeas e plantas insetívoras foram objeto de pesquisa de Darwin, embora os trabalhos do Museu tenham explorado aspectos diferentes dos enfocados pelo naturalista inglês, que, como já foi apontado, estava tentando esclarecer os mecanismos geradores das variações nos seres vivos. ${ }^{52}$

Do conjunto dos textos, os de Alípio de Miranda Ribeiro, pesquisador do Museu desde 1894, são os que mais explicitamente referenciam-se em idéias evolucionistas. ${ }^{53}$ Foi o pesquisador que mais publicou na revista, no período considerado: dentre os 24 títulos de zoologia, 16 são de sua autoria. Dedicou-se a estudos de classificação animal, dentre os quais há 7 extensos trabalhos sobre peixes brasileiros. 
Em obra escrita em 1918, comemorativa do centenário do Museu, Miranda Ribeiro explicitou sua filiação teórica, destacando, primeiramente, o impacto que julgava terem tido as idéias evolucionistas sobre a zoologia. Na sua compreensão, desde "esse notável acontecimento na história da Biologia", que foi a publicação de $A$ Origem das Espécies,

estava morta a definição de espécie, mas não o estava a luta pelo processo da evolução nem da origem. Partidários e contrários exigiam as provas - as séries demonstrativas dos elos da cadeia da evolução. Era natural que dessa procura constante das relações de parentesco d'uma espécie para outra e das variaçōes de cada espécie, os museus entrassem numa nova fase mais propriamente filosófica, ao passo que o acúmulo dessas provas ia gradativamente ligando, entre si, os fatos até então incompreendidos. (Ribeiro, 1919: 53)

Com clareza, Miranda Ribeiro reconhecia as contribuições do pensamento evolutivo para o desenvolvimento da ciência zoológica. Reservou, nesse mesmo texto, vários parágrafos para exemplificar, com achados das últimas décadas, de que forma, "olhando as formas vivas", se poderia "constituir a série dos seres animados." (1919: 54) Assim, relembrou os estudos que levaram à descrição de animais intermediários ou de fósseis, ambos peças fundamentais que vinham permitindo o trabalho de reconstrução da filogenia dos grandes grupos.

Sua adesão às teses recapitulacionistas de Haeckel e de Müller foi ainda reafirmada, ao declarar que

a zoologia estabelecera que todos os seres vivos descendiam um dos outros, numa dicotomização constante e que a espécie variava nessa descendência transmitindo e abolindo caracteres de acordo com a função. A lógica exigia uma síntese dessa análise: $\mathrm{e}$ isso foi o que realizou Fritz Müller em 1864 com a publicação de Für Darwin onde fundamentou a lei ontogenética. 'O desenvolvimento dos animais é uma recapitulação abreviada da sua história evolutiva'". (Ribeiro, 1919:57)

Miranda Ribeiro, contudo, não se envolveu, especificamente, em trabalhos de reconstrução filogenética, como Müller, que pesquisou a embriologia de invertebrados, mas realizou estudos de identificação e classificação animal baseada em anatomia comparada. Em seus trabalhos sobre peixes brasileiros, deixou evidentes suas conviç̧ões evolucionistas, reforçadas por constantes referências a Haeckel e Thomas Huxley (18251895), estudioso da morfologia animal. 
O pesquisador traçou os fundamentos de suas atividades de identificação da fauna em um de seus artigos ( $A M N, 1907: 25-108$ ), explicitando que as classificações zoológicas visavam a "exprimir o desenvolvimento das formas animais no tempo e no espaço". Tal como Darwin e Haeckel, portanto, admitia ser a finalidade da classificação revelar as afinidades genealógicas. Nesse mesmo texto, reuniu argumentos para justificar a razão de ter adotado um certo método de classificação para os peixes que não coincidia com o de vários autores consagrados, entre eles, Haeckel. O que Miranda Ribeiro pretendeu fazer, nesse trabalho, foi estabelecer uma classificação que compatibilizasse os conhecimentos zoológicos disponíveis naquele momento sobre a fauna ictiológica com os critérios utilizados pela sistemática.

Em fins do século XIX, foram descritos animais, até então reconhecidos como invertebrados (moluscos), mas que apresentavam uma estrutura de sustentação - a notocorda -, característica de vertebrados. A partir dessa revelação, os naturalistas trataram de descobrir onde situar, na escala zoológica, esses organismos considerados 'intermediários'. Haeckel os queria em um grupo à parte, mas Miranda Ribeiro defendeu sua inclusão entre os peixes e listou uma série de características que, na sua compreensão, permitiam qualificá-los como "o tipo mais simples" desse grupo (AMN, 1907: 117). Parecia-lhe lógico abrigar em um mesmo grupo os 'intermediários', que estariam na origem dos peixes vertebrados, como também os peixes pulmonados, considerados os representantes atuais dos ancestrais dos anfibios. No entanto, sua ousadia de passar a utilizar critérios próprios de classificação acarretou-lhe críticas contundentes, registradas por Mello Leitão (1937: 247) e Pinto (1994).

Em 1907, Miranda Ribeiro também publicou um texto intitulado o Porquinho da Índia e a Teoria Genealógica, ${ }^{54}$ no qual se posicionou a favor da tese de que esse animal era capaz de cruzar com a preá, contrariando, assim, conforme deixou claro, as conclusões de Haeckel. Havia uma controvérsia na época sobre a viabilidade desse cruzamento. Essa impossibilidade de cruzamento era utilizada por Haeckel como exemplo de especiação a partir de um ancestral comum, isto é, esses dois animais, apesar de serem parentes próximos, não conseguiam mais se cruzar e assim constituíam uma prova da formação de novas espécies a partir de um mesmo ancestral. Miranda Ribeiro foi cauteloso em suas considerações para não deixar dúvida sobre o fato de que suas convicções, apesar de se 
oporem aos argumentos, de nenhuma forma contrariavam os princípios de Haeckel. Assim, para Haeckel, esses dois animais já poderiam ser considerados espécies distintas; para Miranda Ribeiro não. Seus argumentos para isso foram referenciados na definição de espécie apresentada por Darwin, que o citou quatro vezes ao longo do texto.

A leitura dos trabalhos publicados por Miranda Ribeiro, no período, revela que sua perspectiva como pesquisador foi a de um morfologista e, como tal, de um estudioso da estrutura dos organismos vivos ou fósseis. No entanto, seu referencial era evolucionista, e buscou em suas investigações identificar as semelhanças subjacentes entre as espécies e estabelecer as ligações reais entre elas por meio de ancestrais comuns. Não é perceptível, em suas pesquisas, o interesse em compreender como os animais se adaptavam às mudanças em seu ambiente ou a identificação de mecanismos de dispersão geográfica. Como lembra Bowler (1996: 144), esse desinteresse marca uma importante diferença entre o morfologista e o naturalista de campo. De fato, dois importantes zoólogos do Museu Nacional, Müller e Miranda Ribeiro tiveram contribuições totalmente distintas. Enquanto, como se viu, o primeiro se empenhou em compreender o surgimento e o significado das adaptações dos seres vivos, o naturalista brasileiro foi um estudioso da forma animal, centrando seu trabalho na descrição e classificação das espécies.

Os trabalhos de Lacerda e de Miranda Ribeiro foram representativos do projeto do Museu do início do século, expresso pelo diretor, para quem a instituição "ao lado da sistematização dos espécimes naturais" realizaria a "pesquisa experimental" (Lacerda, 1905: 72).

No conjunto dos textos analisados e publicados nos Archivos, a influência mais nítida foi a do evolucionismo haeckeliano nos estudos de Alípio de Miranda Ribeiro. Em Lacerda, o evolucionismo veio apenas salpicar seus estudos bacteriológicos e fisiológicos, cuja marca real é da ciência positiva de Claude Bernard. Essa diferença no período Ladislau Netto, no qual as discussões evolucionistas foram mais nítidas e diversificadas, provavelmente está relacionada não só aos diferentes propósitos da instituição, de uma época e de outra, implementados, respectivamente, por cientistas cujas perspectivas teóricas eram claramente diversas, mas também à própria fase em que se encontrava o debate sobre o tema entre os cientistas como ficará evidente na discussão a seguir. 


\section{Os Significados do Darwinismo na Virada do Século e os Naturalistas Brasileiros}

No final do século XIX e início do XX, os referenciais do evolucionismo, particularmente do haeckelismo e do darwinismo biológico, nortearam os trabalhos do Museu Nacional, ainda que se percebam adesões diferenciadas às concepções de Darwin. É preciso ressaltar, no entanto, conforme mostram Mayr (1991) e Bowler (1992) que, nos anos subseqüentes à publicação de A Origem das Espécies, a aceitação das idéias de Darwin foi, geralmente, parcial também por cientistas da França, Inglaterra, Alemanha e dos Estados Unidos.

Mayr (1991) avalia que as divergências decorreram do fato de que o darwinismo nunca constituiu uma teoria monolítica, uma entidade unitária, de modo que os leitores da obra de Darwin rejeitaram as concepções que julgaram conflitantes com suas convicções e adotaram aquelas com as quais se identificavam. As idéias de que o mundo vivo não era fixo ${ }^{55} \mathrm{e}$ de que os organismos descendiam de um ancestral comum e se transformavam continuamente foram aceitas de forma mais generalizada, pelo menos entre os biólogos ${ }^{56}$ (Coleman, 1977; Mayr, 1982, 1991; Bowler, 1996). A unanimidade, portanto, construiu-se em torno da idéia geral de evolução - inconstância das espécies e descendência com modificação. Entretanto, a compreensão sobre o processo por meio do qual ocorria a transformação não foi consensual.

A idéia de seleção natural, por exemplo, foi amplamente recusada e havia mais de uma razão para rejeitá-la. Uma importante fonte de objeção vinha do fato de que ela era entendida como uma explicação materialista, isto é, natural, para a diversidade do mundo orgânico e, em princípio, prescindia da idéia de Deus. Aceitar a mutabilidade do mundo vivo, reinterpretando a Criação especial, a partir das evidências extraídas da natureza e apresentadas na Origem das Espécies, não foi tão difícil quanto eliminar o desígnio divino das transformações orgânicas e substituí-lo por um processo não teleológico, que não opera a partir de um plano préfixado, mas apenas orienta a evolução de modo a garantir a adaptação dos organismos ao meio cambiante.

Dessa forma, a seleção era interpretada como um mecanismo que não dava oportunidade aos seres vivos de exercerem um papel ativo no direcionamento do curso da evolução e, tampouco, de reagir às mudanças do ambiente, já que as formas não-adaptativas seriam eliminadas. ${ }^{57}$ Nessas 
circunstâncias, mostrava-se, ao mesmo tempo, inconciliável com qualquer ação divina e conflitante com a visão teleológica do mundo. Com isso, noções caras ao século XIX, como progresso e aperfeiçoamento, perdiam força nas explicações sobre as transformações do mundo vivo e de sua história. Conseqüentemente, como assinala Mayr (1991: 94), a seleção natural foi, das formulações darwinistas, a mais rejeitada, não só pelo público leigo, mas também pelos filósofos, teólogos e os próprios biólogos.

O fato de o próprio Darwin admitir, embora com pesos diferentes, tanto a seleção natural de variações espontâneas, de causas ignoradas, quanto a idéia consagrada por Lamarck de herança de variações adquiridas pelo uso ou desuso de partes do organismo, permitiu, numa primeira fase de divulgação das idéias darwinistas, uma certa flexibilidade na adesão a elas. O mecanismo lamarquista dava oportunidade aos seres vivos de exercerem um papel ativo no direcionamento do curso da evolução, em vez de eliminar as formas nãoadaptativas, produzidas pela variação espontânea (como na concepção darwinista). Essa visão correspondia mais perfeitamente à ideologia liberal que dominava o momento, pois não tirava do indivíduo o poder de se adaptar ao meio ambiente e a capacidade de dar respostas às exigências deste. ${ }^{58}$ Assim, os que concebiam a evolução dos organismos como um processo mais intencional privilegiavam a idéia lamarquista sem, com isso, se caracterizar, nessas primeiras décadas pós Origem, uma clara oposição a Darwin.

No Brasil, durante as décadas de 70 e 80 do século XIX, encontram-se ecos dessa fase inicial da expansão do evolucionismo darwinista na atuação do Museu Nacional. Como o diretor da instituição afirmou, o Museu estava "eficazmente iniciado nas mais elevadas cogitações da filosofia evolucionista" ( $A M N$, 1879: 107), e não há evidência, nos trabalhos de zoologia e botânica, de qualquer resistência à idéia geral de evolução, e a própria divisão e organização das seções sofreu o impacto das idéias evolucionistas.

No conjunto dos textos científicos publicados na revista, todavia, como já mostrado, é perceptível um certo ecletismo na compreensão dos fenômenos tratados. Nos Archivos, apareceram explicitamente nos textos de Ladislau Netto, ou apenas esboçadas em Nicolau Moreira, concepções que atribuíam ao meio ambiente um papel essencial no surgimento de modificações nos organismos, cujo sentido era sempre o de aperfeiçoar os indivíduos. Essa visão teleológica do mundo natural tinha tanto espaço na revista quanto a perspectiva oposta de Fritz Müller que admitia a possibilidade de as variações poderem surgir espontaneamente (sem causa conhecida). 
Conviç̧ões à primeira vista contraditórias convivendo na mesma instituição não representam uma condição peculiar da atividade científica no Brasil, mas apenas reiteram a percepção dos historiadores da ciência de que era sobretudo a idéia geral de evolução e não os mecanismos apresentados por Darwin que estavam sendo amplamente aceitos e era isto que contava. Para além desse fato, o próprio trabalho do naturalista inglês, como já foi apontado, também permitia essa flexibilidade nas interpretações.

As idéias lamarquistas possibilitavam com mais facilidade conciliar o evolucionismo com a existência de Deus, orientando o processo de transformação. Ladislau Netto não negava a ocorrência da seleção natural, compreendendo-a, da mesma forma que Haeckel, como um processo, que permitia a manutenção dos indivíduos mais aptos, originários do esforço que realizavam para se adaptarem ao meio ambiente. Essa capacidade de aperfeiçoamento dos seres vivos, entretanto, era concedida pelo Criador $^{59}$ que dirigia, em última instância, todo o processo evolutivo. Tal visão já se distancia de Haeckel, que era ateu, e pode se aproximar do evolucionismo teísta dos anos iniciais de expansão das idéias de Darwin. De acordo com Bowler (1992: 7), essa tendência foi representada por cientistas, que, devido a fortes conviç̧ões religiosas, aceitavam as transformações do mundo natural, mas não abriam mão de compreendê-las como sendo dirigidas pelo desejo do Criador.

Se as idéias evolucionistas de Ladislau Netto, por um lado, permitiam conciliar ciência e religião, por outro, favoreciam um posicionamento mais otimista quanto ao futuro da humanidade e, por conseguinte, da nação brasileira composta de um povo miscigenado e marcado, de acordo com as teorias da época, pela inferioridade racial. Partilhava a concepção que interpretava a espécie humana como diversificada em raças com valor adaptativo muito diferente, o que permitia hierarquizá-las. Ao discutir o desenvolvimento da espécie humana, observou que "a raça indo-germânica" havia conseguido "a mais alta expressão do aperfeiçoamento humano", e completou suas considerações, advertindo que "existe mais diferença entre os mais cultos e mais belos tipos desta raça comparados com os mais imperfeitos e bestiais indivíduos humanos, do que entre estes últimos e os gorilas e chimpanzés" (Netto, 1882: 149).

No entanto, esses "bestiais indivíduos humanos" poderiam, de acordo com sua visão, gradativamente, se aproximar dos brancos e se distanciar dos demais animais. Considerando o meio como determinante do desenvolvimento 
das características, no caso dos seres humanos, a socialização, a cultura e a educação poderiam realizar essa transformação. Pensando assim, aconselhou: "procuremos senhor, por meio da cultura da inteligência e pelo mais amplo desenvolvimento das leis sociológicas, romper as cadeias que nos escravizam ainda ao resto da criação" (Netto, 1882: 158).

Ladislau Netto acreditava, com efeito, no papel civilizador da educação, tendo sido reconhecido pelo seu biógrafo como um homem de ampla visão dos problemas de ensino, pois, já nos anos de 1880 sugeria a importância do ensino prático para a verdadeira aprendizagem (Duarte, 1950: 239). E, como muitos evolucionistas, que, tal como Lamarck, privilegiaram o papel do meio ambiente no desenvolvimento das características dos seres vivos, incluindo o ser humano, advogou uma educação generalizada para todos os níveis sociais. ${ }^{60}$

Fritz Müller, diferentemente, via na imigração uma saída para melhorar a qualidade cultural do país. A superioridade do povo alemão, comparativamente aos habitantes do Brasil, era por ele ressaltada, e o deslocamento em massa dos germânicos para cá acabaria, com o tempo, por substituir o nacional. Seu desejo era de que a imigração alemã, no sul do Brasil, se tornasse "o poder dominante" e afastasse "um dia, de todo, o elemento latino decadente"(Müller apud Mello Leitão, 1937: 311-312). Essa intolerância com o latino não se chocava com suas conviç̧ões sobre a seleção natural; ao contrário, acomodava-se no interior de uma visão de mundo em que os menos aptos desapareceriam pela interferência dessa lei natural e é possível subentender que, no caso, a convivência com os alemães, 'mais aptos', eliminaria o 'latino decadente'.

As opções teóricas de Fritz Müller também se harmonizam com outros aspectos de sua vida pessoal. A objeção de muitos evolucionistas à idéia de seleção natural, pelo fato de que ela "destronava Deus", ${ }^{61}$ nunca foi partilhada pelo naturalista que, desde a juventude, havia abandonado a religião cristã. Em sua biografia, ${ }^{62}$ consta sua participação nos movimentos organizados na Alemanha, em meados da década de 40 do século XIX, contra, entre outros fatores, a influência clerical no governo. Quando adveio a reação contra os manifestantes, teve de sair do país, vindo, em 1852, para a colônia alemã em Santa Catarina.

A não identificação do naturalista alemão com os preceitos religiosos também foi registrada por Hermann von Ihering, diretor do Museu Paulista entre 1894 e 1916, ao escrever o necrológio de Müller. Logo depois de 
chegar ao Brasil, ele assumiu o cargo de professor de Ciências Naturais no Liceu de Florianópolis; contudo, com a admissão dos jesuítas, em 1865, o naturalista teve de deixar o cargo e na percepção de Ihering "era natural que ali não houvesse mais lugar para um homem das opiniões filosóficas de Müller" (Ihering, 1898: 21).

Os textos de Müller e Ladislau Netto conviveram, nas páginas dos Archivos, durante as décadas de 70 e 80 do século XIX, a despeito de suas compreensões distintas sobre a evolução dos seres vivos em geral e do ser humano em particular. Esse ecletismo está relacionado ao próprio projeto da instituição de se manter sintonizada com o movimento científico e isto significava discutir os temas emergentes da época. Além disso, os trabalhos de Müller, um autêntico darwinista, e de Ladislau Netto, evolucionista que combinava a idéia de Deus com a de seleção natural e privilegiava os mecanismos lamarquistas como causa das transformações das espécies, podem ser compreendidos naquele contexto em que, na difusão das idéias de Darwin, predominou uma certa flexibilidade na compreensão sobre quais seriam os mecanismos responsáveis pela origem da variabilidade dos organismos.

Essas décadas, identificadas como as do 'triunfo inicial' das idéias de Darwin, foram separadas do momento da ampla aceitação alcançada pela moderna teoria evolutiva, já na década de 30 do século XX, por um "interlúdio" em que o pensamento antidarwinista dominou o evolucionismo científico (Bowler, 1996: 176). Esse 'interlúdio', também conhecido como os anos do 'eclipse do darwinismo', ${ }^{63}$ iniciou-se por volta de 1890.

Em meados de 1880, August Weismann (1834-1914) iniciou uma série de estudos sobre a hereditariedade, em que procurava responder qual seria a fonte das variações dos organismos. Em seus trabalhos, o zoólogo alemão negou, de modo categórico, a possibilidade de que qualquer alteração decorrente dos efeitos do uso ou desuso de partes ou órgãos de um organismo pudesse ser transmitida às gerações seguintes. Ao verificar que as células germinativas (germe), responsáveis pela transmissão das qualidades hereditárias dos seres vivos, separavam-se em um estágio bem inicial das demais células dos tecidos embrionários que iriam constituir outras partes do corpo (soma), passou a defender a idéia de que o germe era totalmente independente do soma, de modo que as alterações nos tecidos somáticos (do corpo) não interferiam no germe, eram transitórias e desapareciam com o indivíduo, sem serem transferidas para os descendentes. 
Tal conclusão eliminava a possibilidade de que mecanismos lamarquistas contribuíssem para originar as modificações nos organismos. $\mathrm{Na}$ concepção de Weismann, as variações resultariam de causas internas e não da influência do meio; as novas formas de vida surgiriam de alterações ocorridas não nos indivíduos, mas nas "disposições hereditárias" neles contidas, ou seja, de acordo com suas palavras, "a seleção natural atua sobre as disposições ocultas na célula germinal" (Wismann apud Jacob, 1983: 222). Ele imaginou que os determinantes hereditários, no interior do germe, entrariam em competição pelo alimento e concluiu, "os mais vigorosos predominam na transmissão hereditária, o que explicaria a variação em um certo sentido" (Weissmann apud Buican, 1990: 80).

As teorias de Darwin, agora purgadas dos mecanismos lamarquistas, perderam a flexibilidade original e se tornaram, aos olhos de seus críticos, mais dogmáticas. O fato é que o autor de A Origem das Espécies, como já apontado, nunca desconsiderou a importância da herança dos caracteres adquiridos e, em sua obra, Variação dos Animais e Plantas Domésticas (1868), apresentou um mecanismo de hereditariedade - a pangênese - compatível com as idéias lamarquistas. Aliás, esse texto, como lembra Bowler (1992), era freqüentemente mencionado pelos defensores das idéias de Lamarck como prova de que Darwin estava se voltando para essas idéias, provavelmente por estar cedendo aos argumentos anti-selecionistas nada incomuns depois de 1859; nesse trabalho de 1868, havia um capítulo inteiramente dedicado a discutir a influência direta das condições ambientais sobre o desenvolvimento das variações nos seres vivos.

O neodarwinismo, ${ }^{64}$ designação para a tendência que aceitou a exclusividade da seleção para gerir o processo evolutivo, tal como proposto por Weismann, na avaliação de Bowler (1989), longe de promover as idéias darwinistas, contribuiu para radicalizar as posições dos evolucionistas. Aqueles que desejavam preservar um lugar para a herança dos caracteres adquiridos no interior do sistema evolutivo sem excluir a seleção natural ou os que estavam tendentes a considerar as idéias lamarquistas não como complementares, mas sim como uma alternativa à seleção natural sentiram-se estimulados a explorar essas possibilidades com o recrudescimento do debate em torno do evolucionismo darwinista.

Os trabalhos de Lacerda, do início do século, como já ressaltado, mantinham pontos de contato com o lamarquismo e procuravam mostrar que o organismo, na tentativa de responder às mudanças do meio, acionava 
mecanismos internos que o levavam a se modificar. Do mesmo modo, ao discutir o processo de transformação do ser humano, Lacerda atribuía uma importante função ao ambiente. Em seu trabalho, no qual apresentou apreciação e comentários referentes ao $1^{2}$ Congresso Universal das Raças, ocorrido em Paris, em 1911, enfatizou o papel do meio na própria constituição das raças humanas, agora não mais consideradas espécies distintas $^{65}$ e concordou com a 'opinião geral do congresso', de que

não há raças superiores e inferiores, sim raças adiantadas e atrasadas. As diferenças entre as raças no ponto de vista físico, moral e intelectual pensa a maioria do Congresso que são devidas às influências do meio físico, às condições sociais sob as quais têm vivido as raças atrasadas de outro continente. (Lacerda, 1912: 7)

Na sua percepção, tais diferenças poderiam ser superadas por mudanças nas condições externas determinantes das desigualdades. Por isso, considerava que uma nação atrasada deveria "forçosamente receber o auxílio e a educação da mais adiantada" (1912: 13).

Lacerda, no entanto, mostrava-se apreensivo quanto ao futuro e, nessa mesma publicação, discutiu "a crise futura da humanidade" sobre a qual escreveu suas "apreciações teleológicas e sociológicas". Recomendou "iluminar a consciência das massas por uma educação severa de costumes, dar-lhes uma instrução sólida, que fortaleça o seu espírito", sugeriu "um sistema bem organizado de proteção à invalidez, à velhice e à infância desvalida" e contrapôs as prescrições da moral cristã à "desesperadora sentença darwínica", segundo a qual "os fracos ficam se arrastando pelo caminho e sucumbem; os fortes vão por diante e triunfam" (Lacerda, 1912: 101, 106, 108) e, por fim, advertiu:

os olhos da Ciência mal chegam a ver a superfície do mundo visível. A impressão que temos deste mundo pelos sentidos não corresponde fielmente à realidade dele. [Para concluir decepcionado que] apesar de todas essas lacunas devidas à imperfeição dos nossos sentidos e à limitação da nossa inteligência, o orgulho humano, desprezando os ensinamentos da tradição e o reconhecimento da sua ignorância, endeusa o Acaso, e faz dele o maravilhoso fator de todas as magnificências e grandezas do Universo. (1912: 109-110)

A advertência de Lacerda quanto ao acaso decorre de seu entendimento de que o processo orgânico de evolução era teleológico, controlado em alguma medida por leis biológicas internas ao organismo, combinadas 
com a idéia de Deus. Ele exaltava a onipotência de um Deus Criador e admitia ser a "Religião irmã gêmea da Ciência", e com isto queria dizer que as crenças religiosas deveriam preencher "as lacunas insupríveis da ciência". Radicalizou a ponto de reconhecer que a Criação constituía um mistério impenetrável e os seres humanos estariam condenados a ignorá-lo eternamente, de modo que a ciência deveria ficar "encerrada dentro destes limites" e a razão humana não poderia se deixar arrastar "até a loucura de querer desvendar os segredos divinos". Para ele, "a verdade é que existem uns tantos problemas da ciência abstrata ou filosófica, que devem ser considerados insolúveis" (Lacerda, 1905: 137, 138).

Alípio de Miranda Ribeiro, adepto do recapitulacionismo, também se identificava com o lamarquismo. Em conferência realizada no início do século XX, como parte dos festejos comemorativos de um século de atuação do Museu Nacional, Ribeiro fez um apanhado da produção zoológica da instituição. É significativo registrar que, nesse trabalho, o zoólogo do Museu Nacional apresentou Lamarck como "o fundador da teoria da variabilidade da espécie" e ressaltou a importância de ele ter estabelecido "a influência do meio sobre os organismos e a transmissão pela herança de caracteres adquiridos". Darwin, de outro modo, foi reconhecido como quem juntou "as provas confirmativas da variabilidade da espécie", a partir das quais "foram soerguidos os princípios que Lamarck levantara" (Ribeiro, 1919: $51,52)$. A idéia de seleção natural sequer foi mencionada como integrante das concepções de Darwin, visto apenas como o "homem genial" que "soergueu" os princípios lamarquistas.

No período em que o evolucionismo se fragmentou em vertentes que pretenderam complementar ou mesmo substituir o darwinismo biológico, não houve, entre os cientistas que estavam atuando no Museu Nacional destacados para a análise, o surgimento de uma tendência que pudesse ser identificada como neodarwinista. A vertente que adotaram tinha em comum o fato de que compreendiam o processo orgânico de evolução como teleológico, controlado em alguma medida por leis biológicas internas ao organismo, combinadas ou não com a idéia de Deus. O mais difícil para esses cientistas parece ter sido aceitar a inexistência de um plano na natureza. Nessa medida, eram evolucionistas, mas se recusaram a aceitar determinadas conviç̧ões de Darwin que, efetivamente, constituíam o núcleo original de sua teoria. Em sua autobiografia, datada de 1876, Darwin escreveu: 
já não podemos argumentar, por exemplo, que a bela articulação de uma concha bivalve deve ter sido feita por um ser inteligente, do mesmo modo que o homem criou as dobradiças das portas. Parece haver tão pouco planejamento na variabilidade dos seres orgânicos e na ação da seleção natural quanto na direção em que sopra o vento. (Darwin, 2000: 75)

\section{Conclusões}

As idéias evolucionistas que integraram a vida intelectual brasileira desde os anos de 1870, influenciando as teorias sociais, jurídicas e políticas, assim como a literatura, também foram difundidas e incorporadas pelos naturalistas, sobretudo o darwinismo biológico e o haeckelismo. A produção do Museu Nacional é exemplar dessa constatação.

A leitura dos trabalhos científicos realizados pela instituição e publicados em sua revista Archivos, editada desde 1876, mostra que as concepções do darwinismo exerceram influência não só na escolha dos temas e nas interpretações dos fatos biológicos estudados pelos naturalistas do Museu, como também na própria organização institucional. Os pesquisadores da época estavam familiarizados com as principais publicações de Darwin e Haeckel e com as controvérsias geradas a partir das concepções darwinistas. Não há registro de resistência à idéia de que os seres vivos evoluíam; mas a adesão às proposições de Darwin era diferenciada, provavelmente em função de convicções pessoais, religiosas e filosóficas. Essa diversidade coexistiu sem conflito aparente, pois não se encontrou, no âmbito da revista, explicitação de divergências entre os autores.

Em toda a América Latina, não só no Brasil, sempre foi perceptível a apropriação, no final século XIX, das idéias darwinistas como 'arma ideológica' ${ }^{\prime 66}$ para enfrentar as questões sociais emergentes, mas não ficava evidente a influência, nessa região, do evolucionismo, especificamente na produção científica. A análise das atividades do Museu Nacional revela que as idéias darwinistas também foram incorporadas à cultura brasileira por meio das investigações em ciências naturais e, na medida em que o evolucionismo respondia aos anseios de modernização, contribuiu para o desenvolvimento da própria instituição, assim como para a definição dos objetos de pesquisa. 


\section{Notas}

1 Segundo Antônio Paim (1975: 8), Arthur Orlando "evoluiu do positivismo littreista para o monismo haeckeliano".

2 Iniciadas em 1873, estenderam-se até 1889. As conferências abordavam temas culturais, politicos e científicos.

3 Este termo está sendo utilizado com o mesmo sentido atribufdo por Lafuente (1986), para quem a atividade científica expressa uma realidade concreta; as idéias científicas sempre ocorrem ligadas a homens e instituições; seu estudo faz com que o pesquisador se defronte com o problema do tempo e espaço histórico e o obriga a um diálogo concreto com as fontes manuscritas e documentais.

4 Esse estudo é parte de uma investigação mais ampla que abrange, além das atividades do Museu Nacional do Rio de Janeiro, também as do Museu de São Paulo e do Pará, todos voltados para as ciências naturais.

5 O presente estudo não analisa a totalidade das práticas realizadas pelo Museu, haja vista que, além dos trabalhos científicos, a instituição desenvolvia atividades didáticas e organizava e expunha coleções de objetos e seres.

6 Essa concepção também era aceita por Lamarck, embora não fosse rigorosamente a mesma idéia. Para Darwin, a transformação dos seres vivos ocorria de modo gradual, por meio do acúmulo de "variações pequenas, sucessivas e favoráveis" e não por "modificaçōes notáveis ou súbitas" surgidas repentinamente e aos saltos (Darwin, s.d.: 443).

7 Em $A$ Origem das Espécies, Darwin apresentou a idéia de seleção natural como força criativa da evolução; estava ligada a três princípios: a variação, a hereditariedade e a luta pela vida, ou seja, as variações são produzidas a cada geração e essas variações são herdadas, pelo menos uma parte delas, por seus descendentes; os seres vivos produzem mais descendentes do que aqueles que podem sobreviver; os sobreviventes serão aqueles que apresentarem as variações que forem úteis nas suas relações com outros seres, com as condições físicas da vida, e que tiverem bom êxito em deixar descendentes.

s Ver Saldaña (1996:7).

9 Ver Pestre (1995: 495).

v Nesse Ministério, o Museu integrou a seção de "Instrução Pública, Obras Públicas, Saúde Pública, Polícia Civil e Estabelecimentos de Caridade". Ver Lopes (1997: 91).

" Ver Luz (1985: 37), no final da década de 60 do século XIX, em função da guerra civil americana, houve um surto notável da cultura algodoeira no Brasil, que, por sua vez, estimulou a indústria têxtil no país. De outro modo, a Guerra do Paraguai impulsionou vários setores, como o de produtos químicos, instrumentos óticos e náuticos, couros, vidros, entre outros. Além disso, com a queda do preço do café, houve desvio de capital da agricultura para a indústria, sobretudo têxtil.

- O termo indústria, segundo os critérios da época, está associado a "toda e qualquer forma de atividade humana, independente do grau de beneficiamento, do emprego de tecnologia ou das relações sociais subjacentes. Assim, a agricultura ou a criação de gado são classificadas como indústrias, e atividades meramente extrativas ou de coleta simples de materiais da natureza também o são". "Em suma, o uso do termo indústria era praticamente sinônimo de atividade econômica". Ver Jatahi $(1997: 105,131)$. 
Ver Leão (1869: 19) e Relatório do Museu Nacional - Silva (1871: 5).

n Ver os relatórios de Ladislau Netto enviados ao Ministério da Agricultura referentes aos anos de 1870. In: Silva (1871: 5) e Netto (s/d: 6), nos quais fez enfática defesa dos cursos públicos, para os quais pedia verba e espaço físico para a realização.

is Ferreira (1996: 23) discute ser essa uma das funções dos periódicos médicos brasileiros do século XIX. Guardadas as devidas especificidades, tal função também pode ser verificada nos periódicos do Museu Nacional.

6 Ver Regulamento do Museu Nacional. In: $A M N$ (1876: XI).

7 Ver documentos contidos nas Pastas 9-54 Arquivo do Museu Nacional. A título de exemplo, menciono as bibliotecas de instituições nacionais, como as Faculdades de Medicina da Bahia e do Rio de Janeiro, o Colégio Pedro II, os consulados de inúmeros países estrangeiros; os grandes museus de história natural da Europa, América Latina e outras sociedades de pesquisa.

* Para uma discussão pormenorizada sobre esse tema, ver Schwarcz (1995: 43-66).

* $\operatorname{Ver} A M N, 1876$ : 37-43; 1879: 1-14, 15-18; 1878: 33-40, 51-88.

v Les morsures des serpents venineux du Brésil et le Permanganate du Potasse. Faits cliniques recueillis par le Dr. João Baptista de Lacerda (1882).

21 Esse tema, de fato, teve grande repercussão, mas também sofreu muitas críticas como as de Couty, que acabaram por abalar de modo irreversível sua relação com Lacerda, e as de Ihering, publicadas no primeiro volume da Revista do Museu Paulista ( 1895: 195-206), questionando os resultados experimentais.

2 Em 1875, Darwin publicou um estudo intitulado The Movements and Habits of Climbing Plants.

23 Ver, a esse respeito, Mayr (1991: 23).

34 Ver Martins (1997).

s Nasceu na Alemanha em 1822 e faleceu em Blumenau em 1897. Estudou matemática e ciências naturais em Berlim, obtendo título de doutor em Filosofia, em 1841. Freqüentou o curso de medicina entre 1845 e 1848 . Em 1852, por motivos políticos, migrou para o Brasil, estabelecendo-se em Santa Catarina.

s Datado de 1863 , foi publicado, primeiramente, na Alemanha em 1864. Por sugestão de Charles Lyell, a tradução inglesa, publicada em 1869, recebeu o título de Facts and Arguments for Darwin. Em português, a primeira tradução foi feita por Cryptus, pseudônimo do zoólogo do Museu Nacional, Alípio de Miranda Ribeiro e publicada nos anos de 1907-1908. Em 1990, foi publicada outra tradução, com base na inglesa, denominada Fatos e Argumentos a Favor de Darwin, utilizada neste trabalho.

z Dentro da subclasse das lagostas, lagostins e caranguejos, estudou os crustáceos de ordem Amphipoda que têm representantes na água doce e salgada.

23 Ver, por exemplo, Haeckel (s.d.)

* "Quase nada me deu tanta satisfação, quando eu estava trabalhando em $A$ origem, quanto a explicação da grande diferença entre o embrião e o animal adulto, em muitas classes, e da estreita semelhança entre os embriões de uma mesma classe. Ao que eu me lembre, as primeiras resenhas de $A$ origem não deram atenção a isso. Recordo-me de haver expressado minha surpresa a esse respeito numa carta a Asa Gray. Nos últimos anos, vários críticos atribuíram o mérito dessa idéia a Fritz Müller 
e a Haeckel, que sem dúvida a elaboraram de maneira muito mais completa e, em alguns aspectos, mais correta do que a minha. Eu dispunha de material para um capítulo inteiro sobre o assunto e deveria ter feito a discussão mais longa, pois está claro que não consegui impressionar meus leitores. Aquele que consegue fazê-lo, a meu ver, merece todo o crédito"(Darwin, 2000: 108-109).

so Ofício datado de 16 de novembro de 1874, endereçado ao ministro da Agricultura, Arq. Nac. IE $^{7}-77$.

31. Sobre insetos: $A M N, 1879: 19-24 ; 25-30 ; 31-36 ; 37-42 ; 43-46 ; 1878: 1-10 ; 41-50 ; 99$ $124 ; 125-134 ; 1881: 47-85$; sobre crustáceos: $A M N, 1881: 27-34 ; 1892: 125-135 ; 135-$ $152 ; 155-175 ; 179-205 ; 207-220$.

A convergência adaptativa constitui prova da ação da seleção natural sobre os organismos porque é um processo em que espécies distintas, estando sujeitas a pressões seletivas similares, no ambiente, acabam por apresentar caracteres semelhantes, mesmo tratando-se de organismos sem parentesco.

3 Ver, por exemplo, Mayr (1982: 511).

34 Todos os Cordados apresentam a notocorda - uma estrutura de sustentação - em alguma fase de suas vidas. Os vertebrados apresentam-na apenas na fase embrionária, quando é, então, substituída pela coluna vertebral.

× Nascido em 1859, na Suíça, freqüentou a Universidade e o Instituto Dorhn de pesquisas marinhas, em Nápoles. Veio para o Brasil no final de 1884 e aqui permaneceu até 1907, quando voltou à Suíça. Faleceu em 1917. Foi diretor do Museu Paraense.

* A produção de Nicolau Moreira, dirigida para questões práticas relacionadas aos problemas agrícolas brasileiros, não foi publicada nos Archivos, mas em periódicos especializados.

s Nascido na Alemanha em 1850, veio para o Brasil, em 1880, e aqui permaneceu até 1920. Foi diretor do Museu Paulista.

* A Revista Agrícola era órgão de divulgação do Imperial Instituto Fluminense de Agricultura e $O$ Auxiliador era editado pela Sociedade Auxiliadora da Indústria Nacional. Domingues (1995: 220) observa que ambas as instituições "atuaram decisivamente, nas últimas décadas do século XIX, no sentido de divulgar conhecimentos científicos, visando sanar problemas que surgiam na agricultura".

* O regulamento foi baixado em 25 de abril de 1888 . Colleção das Leis do Império do Brazil de 1888.

- Ver artigo 11, cap. III do regulamento de 1888. Colleção das Leis do Império do Brazil (1888: 525).

41 Arq. Nac., IE'-74.

- Ladislau Netto registrou que os cursos públicos eram "freqüentados por todas as classes da sociedade", deixando claro que eram dirigidos "às senhoras, aos estadistas, aos médicos, aos advogados, aos jornalistas e a todos enfim que prezam as boas letras e as ciências naturais" ( $A M N, 1878: 185)$.

4 No Regulamento de 1876, no artigo $1^{2}$ do capítulo I, pode-se ler que "O Museu Nacional é destinado ao estudo da História Natural, particularmente da do Brasil, e ao ensino das ciências físicas e naturais, sobretudo em suas aplicações à agricultura, indústria e artes". 
* Segundo Lacerda (1905: 66), "com esse regulamento draconiano Ladislau nada mais fez do que acumular em torno de si elementos de subversão, levantando conflitos repetidos com os seus subordinados que chegaram até o conhecimento do governo". E, completa, "a arma que ele tinha açacalado para sua defesa, deu-lhe também um golpe fundo".

* Cito, por exemplo, a fauna ornitológica da coleção do Museu, descrita por Lacerda (1905: 88) - em que representantes de países da América do Sul, da Europa, da Ásia, da África e da Austrália estavam "de parceria com as aves brasileiras" - ou mesmo a fauna ictiológica, mencionada por Ribeiro $(A M N, 1903: 67-109)$, na qual há peixes do Oceano Índico, Mar Vermelho, Polinésia, Austrália, Japão, Canadá, Costas setentrionais da Europa para citar alguns hábitats.

* Apenas no regulamento de 1911, foi alterada a abrangência dos estudos estabelecida para a instituição. Eliminou a referência à história natural do globo e tornou a valorizar os estudos voltados para o Brasil. Ver regulamento que baixou com o decreto de 15 de dezembro de 1911. Rio de Janeiro: Imprensa Nacional, 1912. p.3.

- Seus achados, contudo, foram contestadas por George Sternberg, médico americano que presidia a American Health Association. Em relatório, aceito pela comunidade cientifica internacional, incluindo o Instituto Pasteur, julgou fracassadas as tentativas dos sul-americanos de isolar o micróbio da febre amarela e de produzir uma vacina eficaz. Ver Benchimol (1999).

- Trabalhos de antropologia publicados em $A M N(1876,1881,1885)$ e trabalhos de fisiologia publicados em $A M N(1876,1879,1878,1881)$.

* Sobre o curare (AMN, 1901: 163-173); sobre plantas venenosas (AMN, 1909: 1-137); sobre adaptações de plantas carnívoras (AMN, 1897/99: 185-189); sobre dípteros parasitas (AMN, 1901: 153-156; 1903: 175-179; 1905: 155-161; 1907: 229-238).

Ver (AMN, 1903: 1-66; 1907: 1-24; 1909: 193-217).

Ver $(A M N, 1909: 219-256)$.

s O Museu publicou sobre crustáceos (AMN, 1901: 1-151; 1903: 111-118, 119-123, 187-190; 1905: 121-145); sobre minhocas (AMN, 1903: 125-136); sobre peixes (AMN, 1903: 67-109; 1905: 147-154; 1907: 25-128, 129-212; 1909: 167-186; 1911: 1-503; 1915: não paginado.); sobre plantas ornamentais ( $A M N, 1909: 187-192)$; insetívoras (AMN, 1897/99: 185-189). Quanto aos trabalhos de Darwin, cito as seguintes publicações: em 1862, trabalho sobre orquideas - "On the various contrivances by which British and foreign orchids are fertilized by insects"; em 1875, sobre plantas insetívoras - "Insectivorous plants"; em 1881, sobre minhocas - "The formation of vegetable mould through the action of worms".

53 As publicações nos Archivos, de Carlos Moreira, zoólogo do Museu, desde 1888, excetuando-se os relatórios, que trazem considerações sobre o ambiente, são essencialmente descritivas das formas animais acrescidas de breves informações sobre o hábitat em que poderiam ser encontradas. Sua perspectiva de trabalho parece próxima da prática de Miranda Ribeiro. Há em seus textos, freqüentes referências a Darwin (AMN, 1903: 159-168), Müller e Huxley (AMN, 1901: 1-151), mas não encontrei evidências suficientes que me permitissem concluir sobre suas reais opções teóricas. Do mesmo modo, os três artigos de botânica, publicados no período, não foram suficientes para permitir qualquer conclusão quanto aos fundamentos teóricos que estariam orientando a elaboração desses textos. 
Ver (AMN, 1907: 227).

ज Essa concepção, evidentemente, não era exclusiva de Darwin. Jean Baptiste Lamarck (1744-1829) fora seu defensor várias décadas antes.

5. Em especial, botânicos, zoólogos, estudiosos da anatomia comparada, da embriologia e paleontologia.

$\checkmark$ Nos trabalhos de Herbert Spencer, esse era um ponto importante, como mostra Bowler (1996: 169-171).

\$S Sobre essa discussão, ver Bowler (1989: 246-281; 1996: 167-176).

9) $\operatorname{Ver}(A M N, 1878: 198)$.

(1) Gutierrez \& Della Rocca (1998) revelam o posicionamento distinto assumido pelos evolucionistas mexicanos quanto à educação da população.

6 Mayr (1982) menciona que os oponentes à seleção natural assim se referiam.

๔ Ver a apresentação de Nomura no livro de Müller (1990); Ihering (1898); Lacerda (AMN, 1897-1899: XIV).

(3. A expressão foi cunhada, nos anos 40, por Julian Huxley, zoólogo, neto de Thomas Huxley, para se referir ao período em que muitos biólogos rejeitaram a idéia de seleção natural de Darwin. Ver Bowler (1992: 5).

of Termo criado por George J. Romanes, em 1896. Ver Mayr (1991: 110).

( Nem sempre Lacerda admitiu a unidade das raças humanas. Ao estudar os crânios dos Botocudos, trabalho escrito com Rodrigues Peixoto, declarou, em relação à origem do homem americano: "não temos opinião formada", mas admitiu que, "no círculo das hipóteses", "seríamos poligenistas com Agassiz" (AMN, 1876: 75), o que implicava reconhecer esses índios como espécie diferente da branca. No entanto, ao longo do tempo, deixou de ser poligenista retomou o critério de Buffon para definir raça e passou a se opor aos poligenistas, ao reconhecer que os diferentes grupos humanos constituíam raças distintas e não espécies já que eram capazes de se cruzarem, produzindo descendentes férteis (Lacerda, 1911: 6-7).

* Ver observação de Glick (1989: 72), segundo a qual, na maioria dos países hispânicos, não se debateram propriamente os mecanismos biológicos da evolução; nesses pafses, as principais idéias darwinistas foram adotadas como arma para as batalhas ideológicas que dividiram as elites do século XIX.

\section{Referências Bibliográficas}

ALBUQUERQUE, D. V. C. Relatório apresentado à Assembléia Geral Legislativa pelo Ministro Secretário dos Negócios da Agricultura, Commercio e Obras Públicas. Rio de Janeiro, 1870.

AZEVEDO, F. de. A Cultura Brasileira. 4.ed. São Paulo: Editora Universidade de Brasilia, 1963. (1.ed., 1943)

BARROS, R. S. M. de. A Ilustração Brasileira e a Idéia de Universidade. São Paulo: Ed. Convívio/ Edusp, 1986. 
BENCHIMOL, J. L. Dos Micróbios aos Mosquitos: febre amarela e a revolução pasteuriana no Brasil. Rio de Janeiro: Editora Fiocruz/Editora UFRJ, 1999.

BOWLER, P. J. Evolution: the history of an idea. California: University of California Press, 1989.

BOWLER, P. J. The Eclipse of Darwinism. Baltimore: The Johns Hopkins University, 1992. (1.ed., 1983)

BOWLER, P. J. Charles Darwin: the man and his influence. California: University of California Press, 1996. (1.ed., 1990)

BUICAN, D. Darwin e o Darwinismo. Rio de Janeiro: Jorge Zahar Editor, 1990.

COLEMAN, W. Biology in the Nineteenth Century: problems of form, function and transformation. Londres: Cambridge University Press, 1977.

COLLICHIO, T. A. F. Miranda Azevedo e o Darwinismo no Brasil. Belo Horizonte/São Paulo: Itatiaia/Edusp, 1988.

CONRY, Y. L'Introduction du Darwinisme en France au XIX'siècle. Paris: Librairie Philosophique J. Vrin, 1974.

CRUZ COSTA, J. Contribuição à História das Idéias no Brasil. Rio de Janeiro: Livraria José Olympio, 1967.

CRUZ COSTA, J. O pensamento brasileiro sob o Império. In: HOLANDA, S. B.(Coord.). História Geral da Civilização Brasileira. 5.ed. São Paulo: Difel, 1985. Tomo II. v.3 (322-342).

DARWIN,C. A Origem das Espécies. São Paulo: Hemus, s.d. (1.ed., 1859)

DARWIN,C. Autobiografia 1809-1882. Rio de Janeiro: Contraponto, 2000. (1.ed., 1887)

DARWIN, F. The Autobiography of Charles Darwin and Selected Letters. Nova Iorque: Dover publications Inc., 1958. (1.ed., 1892)

DOMINGUES, H. M. B. Ciência: um caso de política - as relações entre as ciências naturais e a agricultura no Brasil, 1995. Tese de Doutorado, São Paulo: Departamento de História da FFLCH/USP.

DUARTE, A. Ladislau Netto (1838-1894). Maceió: Imprensa Oficial, 1950.

FERREIRA, L. O. O Nascimento de uma Instituição Científica: o periódico médico brasileiro da primeira metade do século XIX, 1996. Tese de Doutorado, São Paulo: Departamento de História da FFLCH/USP.

GHISELIN, M. El Triunfo de Darwin. Madrid: Ediciones Cátedra, 1983. (1.ed., 1969)

GLICK, T. F. Darwin y el Darwinismo en el Uruguay y en la America Latina. Uruguay: Universidad de la Republica, 1989.

GOULD, S. J. A Falsa Medida do Homem. São Paulo: Martins Fontes, 1991.

GUTIERREZ, R. R. \& DELLA ROCCA, S. M. El darwinismo social en Mexico. In: LOPES, M. M. \& FIGUEIRÔA, S. F. de M. (Orgs.) Resumos. Campinas: Unicamp, 1998.

HAECKEL, E. Histoire de la Création, Paris: Schleider Frères, s.d. (1.ed., 1867).

IANNI, O. O progresso econômico e o trabalho livre. In: HOLANDA, S. B. (Orgs.) História Geral da Civilização Brasileira: o Brasil monárquico. 5.ed. São Paulo: Difel., 1985. Tomo II, v.3

IHERING, H. V. Fritz Müller. Revista do Museu Paulista. São Paulo: De Hennies 1898.

JACOB, F. A Logica da Vida. Uma história da hereditariedade. Rio de Janeiro: Ed. Graal, 1983. 
JATAHI, S. Exposições Universais: espetáculos da modernidade do século XIX. São Paulo: Hucitec, 1997.

LACERDA, J. B. de. Fastos do Museu Nacional do Rio de Janeiro. Rio de Janeiro, Imprensa Nacional, 1905.

LACERDA, J. B. de. Sur les Métis au Brésil. Paris: Imprimerie Devouge, 1911.

LACERDA, J. B. de. O Congresso Universal das Raças Reunido em Londres (1911): apreciação e comentários. Rio de Janeiro: Papelaria Macedo,1912.

LAFUENTE, A. La ciencia periférica y su especialidad historiográfica. In: SALDAÑA, J. J. (Org.) El Perfil de la Ciencia en América. México: Cuadernos de Quipu, 1986.

LEÃO, J. A F. Relatório apresentado à Assembléia Geral Legislativa pelo Ministro e Secretário de Estado dos Negócios da Agricultura, Commercio e Obras Públicas. Rio de Janeiro: Diário do Rio de Janeiro, 1869.

LOPES, M. M. O Brasil Descobre a Pesquisa Científica. São Paulo: Hucitec, 1997.

LUZ, N. V. As tentativas da industrialização no Brasil. In: HOLANDA, S. B. (Orgs.) História Geral da Civilização Brasileira: o Brasil monárquico. 5.ed. São Paulo: Difel., 1985. Tomo II, v. 3

MARTINS, L. A. C. P. Lamarck e as quatro leis da variação das espécies. Episteme: filosofia e história das ciências em revista, 2(3): 33-54, 1997.

MAYR, E. The Growth of Biological Thought: diversity, evolution and Inheritance. Cambridge: Harvard University Press, 1982.

MAYR, E. One Long Argument: Charles Darwin and the genesis of modern evolutionary thought. Cambridge: Harvard University Press, 1991.

MELlO LEITÃo, C. de. A Biologia no Brasil. São Paulo/Rio de Janeiro/ Recife,/ Porto Alegre: Companhia Editora Nacional, 1937.

MONTGOMERY, W. Germany. In: GLICK, T. E. (Orgs.) The Comparative Reception of Darwinism. Chicago: University of Chicago Press, 1988.

MÜLLER, F. Fatos e Argumentos a Favor de Darwin. Florianópolis/Rio de Janeiro: Edições Fundação Catarinense de Cultura/CPRM/DNPM, 1990. (1.ed. 1863/1864)

NEIVA, A. Esboço Histórico sobre a Botânica e Zoologia no Brasil. São Paulo: Sociedade Impressora Paulista, 1929.

NETTO, L. S. M. Observaciones sobre la teoria de la evolucion. Anales de la Sociedad Científica Argentina. Tomo XIII: 147-158, 1882.

PAIM, A. História das Idéias Filosóficas no Brasil. 2.ed. São Paulo: Editorial Grijalbo/Edusp, 1974. (1edição, 1967)

PAIM, A. Introdução. In: ORLANDO, A. (Org.) Ensaios de Crítica. São Paulo: Editora da Universidade de São Paulo/Editorial Grijalbo Ltda., 1975.

PESTRE, D. Pour une histoire sociale et culturelle des sciences: nouvelles définitions, nouveaux objets, nouvelles pratiques. In: ECOLE DES HAUTES ETUDES EN SCIENCES SOCLALES, 3, 1995, Paris.. Annale... Paris, 1995. p. 487-523.

PINTO, O. M. de. A zoologia no Brasil. In: AZEVEDO, F. (Org.) As Ciências no Brasil. Rio de Janeiro: UFRJ, 1994. v.2 
RIBEIRO, A. M. A zoologia no século do Museu Nacional do Rio de Janeiro. Archivos do Museu Nacional, 1919. v.19.

RIBEIRO, A. M. A Comissão Rondon e o Museu Nacional do Rio de Janeiro: Ministério da agricultura/Comissão Nacional de Proteção aos Índios. Publicação n. 49, 1945. (Conferências realizadas pelo Professor Alípio de Miranda Ribeiro, no Museu Nacional do Rio de Janeiro, em 1916). (1.ed., 1916).

ROMERO, S. Obra Filosófica. Rio de Janeiro/São Paulo: Livraria José Olympio/Edusp, 1969. (Reunião de obras de 1878, 1894 e 1895).

SÁ, M. R. \& DOMINGUES, H. M. B. O Museu Nacional e o ensino das ciências naturais no Brasil no século XIX. Revista Brasileira de História da Ciência, 15: 79-88, 1996.

SALDAÑA, J. J. Marcos conceptuales de la historia de las ciencias en Latinoamérica positivismo y economicismo. In: SALDAÑA, J. J. (Org.) El Perfil de la Ciencia en América. Mexico: Ed. Soc. Latinoamericana de las ciencias y tecnologia, 1996.

SCHWARCZ, L. M. O Espetáculo das Rą̧as: cientistas, instituições e questão racial no Brasil 1870 - 1930. São Paulo: Companhia das Letras, 1995. (14 reimpressão)

SILVA, T. M. F. P. Relatório apresentado à Assembléia Geral Legislativa pelo Ministro e Secretário de Estado dos Negócios da Agricultura, Commercio e Obras Públicas. Rio de Janeiro: Diário do Rio de Janeiro, 1871.

STEBBINS, R. E. France. In: GLICK, T. F. (Org.) The Comparative Reception of Darwinism. Chicago: University of Chicago, 1988.

Fontes Arquivisticas

Arquivo do Museu Nacional

Pastas 1 (1818); 9 - 54 (1870-1915)

Colleção das Leis do Império do Brazil de 1888. Parte II, tomo LI. Actos do Poder Executivo de 1888. Rio de Janeiro: Imprensa Nacional, 1889. v. I

Regulamento do Museu Nacional a que se refere o Decreto de 3211. Rio de Janeiro: Imprensa Nacional, 1899.

Regulamento que baixou com o decreto n. 9211, de 15 de dezembro de 1911. Rio de Janeiro: Imprensa Nacional, 1912.

Archivos do Museu Nacional (AMN), Rio de Janeiro, vol. I-XVII, 1876-1915.

Publicações avulsas do Museu Nacional (vários autores). João Baptista de Lacerda. Comemoraçōes do centenário de nascimento. 1846-1946. Rio de Janeiro, Departamento de Imprensa Nacional, 1946.

Netto, Ladislau s/d Relatório do Museu Nacional de 1873, Rio de Janeiro: Typografia da Gazeta Jurídica. 1874.

Relatório do Museu Nacional de 1874. Rio de Janeiro: Rua do Ouvidor, 89, 1875.

Relatório do Museu Nacional de 1876. Rio de Janeiro: Typografia de João Inácio da Silva, 1877.

Arquivo Nacional do Rio de Janeiro (Arq. Nac.)

Documentação do Ministério da Agricultura, Comércio e Obras Públicas. Museu Nacional. Pacotes: $\mathrm{IE}^{7}-64 \mathrm{a}^{\mathrm{IE}}-77$ (1871-1889). 


\section{Controvérsias Evolucionistas no Brasil do Século XIX}

Heloisa Maria Bertol Domingues

e Magali Romero Sá

\section{Introdução}

A recepção da teoria de Darwin no Brasil, nas décadas seguintes à publicação de $A$ Origem das Espécies (1859), foi controvertida tanto no meio científico quanto no meio intelectual. Esta análise sobre o tema prende-se principalmente ao debate que se travou no meio científico, pois considera que as diferenças refletiam as linhas teóricas que orientavam os trabalhos dos cientistas, e estes, como todo o sistema de conhecimento, inseriam-se no contexto cultural mais geral do país. ${ }^{1}$

Neste artigo são analisadas particularmente as controvérsias que surgiram em torno da idéia de evolução, juntamente com a questão da origem do homem e a da teoria das raças contidas na teoria da seleção das espécies de Darwin, mas que eram também objeto de teorias que orientavam ciências, como a antropologia ou a geologia. No Brasil, nas últimas décadas do século XIX, tanto o evolucionismo quanto a teoria racial eram eixos orientadores das ciências naturais que moldavam o pensamento dos intelectuais que idealizavam a nação (como aconteceu em tantas outras).

O processo de recepção das ciências engendra um complexo de relações, que constituem um aspecto não negligenciável do desenvolvimento da produção científica. De um lado, ocorre por interação dos processos de racionalidade e estilos científicos; de outro, depende das condições de receptividade no meio em que se reproduzem (condições estas que podem ser institucionais ou político-ideológicas). ${ }^{2}$ Nesse sentido, verificam-se tais condições dando ênfase ao complexo de relações sociais das ciências. 
No Brasil, desde meados do século XIX, os intelectuais buscavam inserir o país, pela construção da sua história, na marcha temporal da 'civilização'. Porém, do ponto de vista social, esta 'marcha' encontrava um empecilho considerável: a escravidão, uma instituição muito combatida. Ainda assim, para os teóricos das raças e construtores da civilização 'nacional', a questão, no século XIX, não foi inserir os negros escravos na sociedade, pois estes eram considerados estrangeiros. A questão foi inserir os índios nessa construção social do país, pois eles se apresentavam como alternativa à mão-de-obra escrava, e, além disso, conheciam o interior do país, que se pretendia explorar. A prática e o desenvolvimento das ciências naturais acabariam contribuindo para dar um lugar social a esses grupos que estavam na iminência de se tornarem cidadãos. É neste debate ideológico que se pode situar a recepção do darwinismo social no Brasil. Porém, o darwinismo no Brasil não foi unicamente social; na biologia ele também teve repercussão.

Desde a segunda metade do século XIX, à época em que Darwin publicava o seu famoso livro The Origins of Species (1859), as ciências naturais desenvolvidas no país passaram a integrar novas áreas que eram parte do contexto científico internacional. Foi nessa época que se desenvolveram novos ramos das ciências naturais, como a antropologia e a geologia, ambas prática e conceitualmente diferentes das velhas etnografia e mineralogia, respectivamente. E foram principalmente essas ciências que abordaram a questão da evolução, criando partidos e resistências ao darwinismo; contudo, não somente nelas o darwinismo foi objeto de debate. Na botânica e na zoologia, os efeitos do darwinismo se fizeram sentir, embora as conclusões nem sempre fossem a seu favor.

O Brasil era um país alvo de viagens naturalistas, aliás, como o foi toda a América Latina. Da viagem do Beagle e do diálogo entre Bates e Wallace, consolidou-se a conhecida teoria darwinista (Ferreira, 1990). Bates e Wallace permaneceram vários anos na Amazônia brasileira, colhendo espécies e estudando as singularidades e o desenvolvimento naquele meio físico tão especial. Darwin passou quatro meses no Brasil em 1832; durante a sua viagem à América do Sul, tendo pela primeira vez entrado em contato com a floresta tropical, numa passagem do seu diário, escreveu (Darwin, 1890: 9):

Brasil, 29 de fevereiro - O dia passou deliciosamente. Mas 'delícia' é termo insuficiente para exprimir as emoções sentidas por um naturalista que, pela primeira vez, se viu a sós com a natureza no seio de uma floresta brasileira. 
Quando da sua passagem pelo Rio de Janeiro, Darwin visitou o Jardim Botânico, onde observou que

cresciam plantas muito conhecidas pela grande utilidade de suas propriedades. As folhas da cânfora, da canela e do cravo desprendiam um aroma muito delicioso; e a fruta-pão, a jaca e manga disputavam a primazia da magnificência da folhagem. A paisagem dos arredores da Bahia quase que se caracteriza por estas duas últimas árvores. (Darwin, 1890: 23)

Apesar de Darwin ter visitado o Jardim Botânico e ter exaltado a natureza do país, não fez referências aos naturalistas brasileiros nem tampouco visitou o Museu Nacional que, à época, já possuía uma exposição de história natural aberta ao público.

Mas o Brasil não foi somente o palco da elaboração da teoria da evolução por seleção natural; também foi neste país que nasceu imediatatamente um suporte a ela. Aqui surgiu uma das mais importantes interpretações da teoria na área da biologia: a de Fritz Müller. O naturalista era um imigrante alemão que habitava uma pequena cidade do sul do país - Desterro, na província de Santa Catarina. Em 1864, ficou conhecido no meio científico internacional pela publicação de um pequeno livro Für Darwin, no qual demonstrou, através de estudos embriológicos em crustáceos, a teoria de Darwin.

Müller descobriu a forma larval náuplio ${ }^{3}$ nos crustáceos superiores (malacóstracos), que, anteriormente, era atribuída apenas aos inferiores (entomóstracos), mostrando, assim, que durante o estágio embriológico os crustáceos superiores passavam primeiramente pelo estágio de larva náuplio; comparou os apêndices dos crustáceos, machos e fêmeas, do gênero Tanais, demonstrando o dimorfismo sexual; fez estudos sobre respiração aérea de crustáceos, bem como comparou a estrutura do coração nos amphipoda $e$ isopoda. ${ }^{4}$ Neste mesmo trabalho, Müller lançou as bases para a lei da biogenética de Ernest Haeckel - a ontogênese recapitula a filogênese -, quando afirmou que "No curto período de poucas semanas ou meses, as formas cambiantes do embrião e das larvas fazem passar diante de nós uma figura mais ou menos exata das transformações sofridas pela espécie no correr dos tempos, até atingir o seu estado atual" (Müller apud Castro, 1992: 82).

A repercussão ao livro de Müller nos círculos científicos alemães e ingleses foi imediata, sendo que a sua tradução para o inglês foi sugerida pelo próprio Darwin, em 1869. Müller tornou-se amigo e colaborador de Darwin, com quem trocava correspondência, abordando seus estudos sobre 
diferentes grupos de animais e vegetais e a inter-relação entre eles, bem como enviava material para estudo (Müller, 1865).

Fritz Müller, que residia no país desde 1852, produziu a maioria dos seus 248 trabalhos científicos praticamente isolado do centro científico e cultural do Brasil; somente depois de ter se tornado conhecido internacionalmente, que passou a ter algum financiamento institucional no país.

Em 1876, foi contratado como viajante naturalista do Museu Nacional, e seu trabalho consistia em enviar material para enriquecer as suas coleções. Durante o tempo em que atuou como naturalista do Museu, de 1876 a 1891, Müller publicou nos seus Archivos nada menos do que 17 trabalhos sobre insetos, crustáceos e fertilização das plantas, todos relacionados à teoria darwinista. ${ }^{5}$ Apesar da importante produção científica, os trabalhos desse pesquisador não obtiveram, no Brasil, o mesmo impacto e reconhecimento que alcançaram na Alemanha ou com o próprio Darwin. Segundo Roquette-Pinto, diretor do Museu Nacional entre 1926 e 1936, isso se deu por ter Müller publicado a maioria dos seus trabalhos em revistas científicas, além de terem sido suas observações extremamente especializadas no campo da biologia. Segundo Roquette Pinto, Müller era "um dos maiores monumentos científicos criados na América do Sul", mas "a sua inquebrantável moral, o seu gosto pela ampla liberdade e mesmo os seus princípios filosóficos que o levaram a abençoar o cabo do machado; tudo isto explica o incidente: Fritz Müller perdeu o emprego em 1891" (Roquette-Pinto, 1929: 21).

Na década de 70, começaram a se esboçar as posições dos brasileiros em relação ao darwinismo. E, embora a teoria tivesse defensores no meio científico brasileiro, encontrou muitos contestadores. Porém, o mesmo não aconteceu em relação à idéia de evolução. Essa idéia ganhou um sentido mais amplo no Brasil nessa época e apresentava-se dividida entre o que se chamou 'darwinismo' (tido como um sistema de idéias relativo aos princípios característicos da evolução entendida por Darwin) e o que foi simplesmente evolucionismo. Ao se observar as controvérsias surgidas no país sobre a teoria da seleção das espécies, percebe-se que há uma corrente contrária, também evolucionista, mas cuja relação teórico-epistemológica não pode ser remetida a Darwin. 


\section{As Resistências a Darwin}

Do ponto de vista das relações sociais nas ciências, particularmente sobre a questão do darwinismo, o Brasil pode ser considerado um país sui generis. Além da discreta presença de Fritz Müller, correspondendo-se com os grandes da Europa, havia a figura política do Imperador, exercendo um papel preponderante nessas relações e também correspondendo-se com vários cientistas renomados.

Pedro II foi um dos únicos governantes a ser eleito para um dos oito lugares reservados a sócios estrangeiros na Academia de Ciências de Paris e o único brasileiro a ser admitido. ${ }^{6}$ Ele foi membro da Academia de Paris não por sua produção científica, mas pelas discussões que travou com os cientistas e também pela 'generosidade' com que financiou inúmeros trabalhos científicos. ${ }^{7} \mathrm{~A}$ análise da recepção e da resistência à teoria de Darwin no país mostrou uma relação triangular que envolvia a figura política do Imperador, além dos cientistas brasileiros (em geral formados na Europa) e os colegas europeus, inclusive o próprio Darwin e o seu grande opositor, Quatrefages.

No tocante à questão do darwinismo ou da oposição a ele, a correspodência trocada entre Pedro II e Quatrafages de Bréau revelou-se uma fonte importante. Nessa correspondência, que durou do início dos anos 70 até a morte de Pedro II, em 1891, observa-se que este sempre concordou com as teses antidarwinistas de Quatrefages e mesmo incentivou-as, enviando-lhe, por intermédio do Museu Nacional, ossos fósseis e materiais indígenas para serem analisados. ${ }^{8} \mathrm{Em}$ uma de suas cartas, o Imperador dizia por exemplo: "A doutrina da evolução é muito decepcionante, embora se apóie sobre muitos fatos". 9

Em outra carta, ele dizia:

Agradeço-lhe a carta, tão interessante, do dia 29 de dezembro. O estudo da geologia é um dos que mais me atraem e gosto muito de ver os fatos constatados por autoridades como vós. (...) Acabo de ler a coleção de cartas de meu amigo Agassiz, publicadas pela viúva. Que teoria audaciosa, e como ele não desejava enganar-se sobre os fatos. Nós conversamos seguidamente sobre isto, nas duas vêzes que ele esteve no Rio. (...) A questão das origens é um tema de discussão, que eu gostaria de conhecer a sua opinião atual, principalmente sobre os macacos antropomórficos. Nada me repugna mais do que admitir, como hipótese, esta evolução para a espécie humana, mas se são os fatos que me faltam, eu temo mesmo dizer, como Gaudry, que seria o "cynoppitecus". Hartman acaba de publicar um livro sobre os 'antropomorfódes', mas ele é apenas um filósofo de uma escola que eu combaterei sempre os princípios. ${ }^{10}$ 


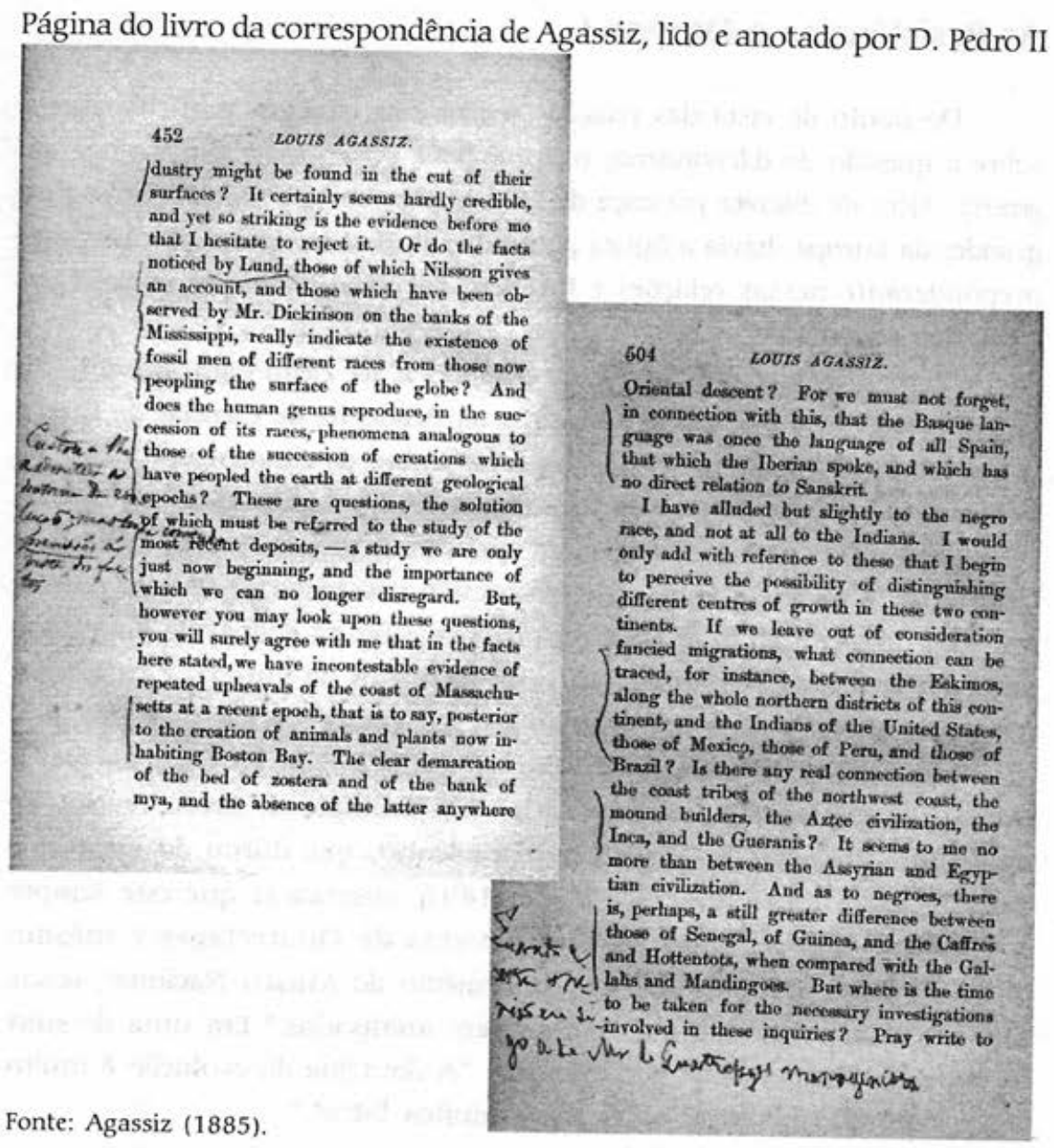

Fonte: Agassiz (1885).

Mesmo depois de ter deixado o governo do Brasil, pouco antes de sua morte, Pedro II reafirmava suas conviç̧ões contra o evolucionismo: "Eu temo lhe dizer o quanto a leitura de Van den Ghegn me interessou. Mas eu continuo a crer que o primeiro homem não foi negro, nem descendente do macaco. Eu repetiria com o autor que vale mais a ignorância cega do que a ilusão da ciência". "1

As questões sobre a descendência dos homens foram talvez as que mais partidarismos criaram, e elas se cruzaram nas discussões com as da origem tanto do homem quanto da sociedade e acabaram por buscar explicações para diferenças raciais e culturais. No Brasil, os métodos utilizados para explicar as diferenças foram basicamente aqueles institucionalizados na França pela antropologia craniométrica e 
antropométrica de Paul Broca e Quatrefages; nesse sentido, foram essas teorias que repercutiram e com grande força debateram com a teoria darwinista. No Brasil, essa antropologia comę̧ou a se desenvolver a partir da segunda metade do século XIX, ainda dividida entre a velha etnografia e as novas práticas de analisar fósseis e datar a terra e a cultura social.

Quatrefages, em suas cartas ao Imperador, manifestava grande interesse pelo Brasil e pelo que se realizava em suas instituições científicas, ao mesmo tempo que discutia com o amigo suas teorias e publicações. Assim, por exemplo, numa carta de 1873, depois de perguntar pelos trabalhos do Museu Nacional, comentava sobre a publicação dos resultados de seus estudos recentes nos quais introduzia a sua teoria das raças:

É uma craniologia geral aplicada à caracterização das raças humanas. (...) Embora ainda pouco avançado, este estudo já deu bons resultados que confirmam em todos os pontos as idéias as quais haviam conduzido muitas das minhas pesquisas anteriores. Eu espero que seja reconhecido mais e mais que os tipos pré-históricos os mais antigos têm ainda representantes nas populações atuais; que o desenvolvimento das qualidades e das faculdades humanas é independente da forma dos crâneos; o crâneo de Neanderthal, que alguns antropólogos pensaram que podia pertencer apenas a uma espécie de besta bruta e feroz, se encontra não somente entre os australianos, mas entre nós, no tempo e no espaço. ${ }^{12}$

O diálogo de Quatrefages com o Imperador foi sempre no sentido de discutir as teorias. Pouco tempo depois de ter sido publicado o livro de Quatrefages sobre as raças, Pedro II enviou-lhe os fósseis do Brasil para serem analisados, inclusive amostras dos que haviam sido descobertos pelo dinamarquês Lund no ano de 1840, na região do centro-leste chamada Lagoa Santa, província de Minas Gerais. Pedro II enviou fósseis também para Virchow, na Alemanha, na mesma ocasião.

Os fósseis de Lund foram um dos pontos fortes da controvérsia entre os que professavam o darwinismo e os resistentes à sua aceitação. Para Quatrefages, esses fósseis não representavam a antigüidade do homem americano, pois eram fósseis bem mais recentes do que seriam os do homem de Neandhertal, mas não diferiam culturalmente deste, conclusão a que chegara pela craniometria. Isso significava que eles podiam ser "comparáveis às bestas brutas e ferozes". ${ }^{13} \mathrm{Em} \mathrm{1874,} \mathrm{Quatrefages} \mathrm{pedia}$ ao Imperador para ordenar que se realizassem novas expedições nas cavernas onde estivera Lund, pois, para ele, Lund havia acreditado ter encontrado ossos humanos contemporâneos de espécies animais fósseis, o que ele colocava em dúvida. 
Sob a mesma perspectiva teórica de Quatrefages situava-se, por exemplo, a antropologia dos médicos João Batista de Lacerda e Rodrigues Peixoto, ambos do Museu Nacional, a qual mereceu enormes elogios do próprio Quatrefages. O trabalho de Lacerda e Peixoto, em 1878, ganhou ainda o reconhecimento da comunidade francesa de antropologia, pois, nessa ocasião, eles foram homenageados com medalhas na Exposição Antropológica de Paris. ${ }^{14}$

Lacerda e Rodrigues Peixoto examinaram os fósseis encontrados por Lund e o seu resultado foi publicado no primeiro número dos Archivos do Museu Nacional, em $1876 .{ }^{15}$ Nesse trabalho, Lacerda, que foi mais tarde o substituto de Ladislau Netto na direção do Museu Nacional, e Peixoto analisaram vários crânios de índios de diversas regiões do país, como São Mateus, Ceará etc. e os compararam ao crânio da coleção de Lund. Alguns desses crânios foram classificados como sendo de índios botocudos, que os autores acreditavam ser os tipos mais primitivos, incluindo aí o tipo Lagoa Santa. Sobre o tipo Ceará, que eles comparavam ao crânio encontrado por Lund, diziam: "A um crâneo assim constituído deve ter correspondido um grau de inferioridade intelectual muito próximo ao dos macacos antropomorfos" (Lacerda \& Peixoto, 1876: 68). Lacerda e Peixoto chegaram a aproximar o homem do macaco, mas não admitiram a relação de descendência. Eles explicaram, no seu texto, que entendiam a tradição antropológica a partir de

Retzius, Morton, Prichard, Wagner [que] se dilatou servindo de base para os 'moderníssimos' estudos de Broca, Pruner-Brey, Quatrefages, Virchow, Topinard e outros, cujos trabalhos mais práticos e cujas vistas mais largas tendem hoje a nos dar uma nova face à ciência antropológica. (Lacerda \& Peixoto, 1876: 47)

Na conclusão desse trabalho, em que usaram o método craniométrico tal como Broca e Quatrefages, Lacerda \& Peixoto (1876: 47) fizeram algumas considerações comparativas, deixando entrever algum princípio evolucionista:

O predomínio da dolicocefalia nesta série vem trazer mais um argumento valioso para provar que o tipo das raças americanas em geral é dolicocéfala; por outro lado a existência na série de alguns subdolicocéfalos e de um mesaticéfalo parece indicar que o tipo primitivo da raça dos Botocudos tende a modificar-se pelo cruzamento com outra raça de tipo diferente, e essa presunção é tanto mais bem fundada, quanto vemos aparecer na mesma série crânios 'mesorrinios' e 'leptorrinios', o que inculca mistura de raças. 


\section{E continuam:}

Pela sua pequena capacidade craneana os Botocudos devem ser colocados a par dos Neo-Caledonios e dos Australianos, istoé, entre as raças mais notáveis pelo seu grau de inferioridade intelectual. As suas aptidões são, com efeito, muito limitadas e difícil é fazê-los entrar no caminho da civilização. (...) O crânio fóssil da Lagoa Santa, uma das preciosidades da nossa coleção, assemelha-se muito por seus caracteres aos crânios dos Botocudos. O seu índice cefálico é representado por 69,72, indica uma dolicocefalia superior à dos patagônios e dos esquimós, as duas raças mais dolicocéfalas do mundo. (...) o que leva-nos a admitir que no decurso de muitos séculos a raça dos Botocudos não tem subido um só grau na escala da intelectualidade; o seu ângulo facial de Cloquet é de $67^{\circ}$. É um representante da raça prehistórica, contemporânea do cavalo fóssil e outras espécies já extintas.

E, numa defesa da idéia poligenista, terminam o artigo dizendo:

Se é verdade que a formação do novo continente precedeu à formação do velho mundo, como quer Lund, fundado nas suas observações geológicas sobre o 'plateau' central do Brasil, se é exato, como diz Morton, que as mesmas crenças, os mesmos costumes, os mesmos ritos e até a mesma língua se encontram com pequenas diferenças em todos os povos esparsos no imenso terrritório da América, não será talvez arrojada a proposição de Simonin quando diz que o Indio americano é um produto do solo americano! [E, então, concluem:] Seja-nos, pois, lícito declarar que a respeito de tais questões não temos opinião formada, e quando no círculo das hipóteses prováveis houvéssemos de aceitar alguma, seríamos poligenistas com Agassiz. É possível que a América fosse um dos centros da criação e que mais tarde povos emigrados da Ásia ou de outros pontos do globo, mais próximos, viessem fundir-se com a raça primitiva, produzindo a raça atual. Tal é um dos grandes problemas propostos à ciência do presente e que talvez a ciência do futuro chegue a demonstrar. (Lacerda \& Peixoto, 1876: 74)

Esse trabalho de Lacerda e Peixoto recebeu comentários favoráveis de Quatrefages em Paris. Em uma das sessões da Academia de Ciências de Paris, em 1883, Quatrefages disse que estava feliz por elogiar o importante trabalho dos dois cientistas brasileiros, pois, conforme a sua teoria, analisavam as diferenças entre os crânios dos botocudos, os analisados por Lund e os de Maracá, observando que, estes últimos, embora menos dolicocéfalos do que os dos botocudos, apresentavam os demais caracteres, demostrando estreita identidade entre eles (Quatrefages, 1883).

A prática científica de Lacerda e Peixoto estava completamente de acordo com a antropologia parisiense. Em um outro trabalho, intitulado "Novos estudos antropológicos sobre os botocudos", publicado no sexto volume dos 
Archivos do Museu Nacional, volume este inteiramente dedicado à Exposição Antropológica Brasileira de 1882, Rodrigues Peixoto (1885: 208) reafirmava a mesma orientação teórico-epistemológica: "Os processos seguidos por nós são os da escola francesa, recomendados por Broca nas suas 'Instruções'".

Neste mesmo sexto volume do Archivos do Museu Nacional, João Batista de Lacerda publicou um artigo intitulado "O homem dos sambaquis contribuição para a antropologia brasileira" (1885), no qual iniciou dizendo que esse trabalho se identificava com os objetivos mais gerais da antropologia, buscando solução para os problemas pré-históricos, explorando cavernas, visitando necrópoles abandonadas, interrogando monumentos carcomidos pelo tempo, decifrando caracteres gravados na face desses monumentos, buscando as tradições perdidas das remotas gerações humanas: "Dir-se-ia o homem empinhado em uma luta consigo mesmo para chegar às fontes, ainda obscuras e misteriosas, da sua origem no tempo e no espaço" (Lacerda, 1885: 175).

De fato, Lacerda (1885: 177) não fazia cogitações sobre a idade das culturas nativas do país, ao contrário:

A questão das origens é um implacável ponto de interrogação que surge a cada instante para desconcertar as mais engenhosas combinações e as mais plausíveis hipóteses. O fio condutor perde-se no emaranhado desse labirinto e ainda hoje não se pode saber ao certo de que manancial provieram as correntes humanas que cobriram, desde antiquíssimas Eras, o solo do Brasil.

Porém, sobre a 'evolução' social desses grupos, dizia que os construtores dos sambaquis eram inábeis, tinham feito obras grosseiras, sem formas regulares e prefixas, que não queriam perpetuar ou materializar um pensamento qualquer, senão as teriam fundido em outros moldes, talhado com uniformidade e um certo cunho artístico. E, afirmando a sua visão evolucionista, dizia, juntamente com Peixoto:

Nas manifestações da atividade cerebral humana, sob o ponto de vista da arte ou da indústria, há, é verdade, uma infinita gradação que ascende desde o mais ínfimo representante da espécie até o mais portentoso produto dela. Desde o austrálio e o tasmanio, quase nivelados ao bruto até o artístico cérebro de Miguel Ângelo ou de Raphael, que inúmeras modalidades, que gradação, infinitas para a concepção da beleza e da regularidade das formas. O homem dos sambaquis não possúa certamente como os astecas e os peruanos, um cérebro afeiçoado às produções artísticas; sua inferioridade cerebral estava mesmo colocada a um nível tão baixo que não the permitia pensar em erguer monumentos cuja existência pressupõe um grau de civilização adiantada. (Lacerda \& Peixoto, 1876: 179) 
Assim, reafirmando a inferioridade social e/ou intelectual do homem do sambaqui, Lacerda e Peixoto concluíram que um sambaqui não podia ser considerado um monumento arqueológico, porque

as raças aborígenes desta parte do novo mundo não deixavam sequer vestígios apagados de uma civilização incipiente; elas atravessaram os séculos, pela maior parte, na mais profunda barbarie e prolongaram até hoje essa longa e tenebrosa fase de sua vida primitiva. (...) No mesmo nível de civilização, ou melhor dizer de profunda barbarie em que elas apareceram se conservam até hoje. (Lacerda \& Peixoto, 1876: 182)

Um sambaqui teria, segundo Lacerda, a mesma origem dos 'kjokhenmoddins', da Dinamarca. Na segunda parte desse trabalho, Lacerda discutiu suas conclusões anteriores sobre as medições dos ossos encontrados no sambaqui e concluiu da mesma forma:

Tudo pois nos leva a crer que esse tipo, cujos restos foram exumados dos sambaquis do Paraná e Santa Catarina, ocupava um nível muito baixo na escala humana; e que ele pode ser equiparado aos povos mais selvagens que hoje conhecemos. Entre esses há um com o qual o tipo do sambaqui oferece as maiores analogias morfológicas do crâneo: são os Botocudos. (Lacerda, 1885: 202)

Sobre esse trabalho e todo o número seis dos Archivos do Museu Nacional, pronunciou-se novamente Quatrefages na Academia des Sciences de Paris (1885: 467). Além de um breve comentário sobre o trabalho de Charles Hartt que tratava também dos sambaquis, Quatrefages se deteve no artigo de Lacerda, concordando com as suas conclusões sobre serem os sambaquis 'koekkenmoedings' do Brasil e concordando também com as medidas dos treze crânios de sambaquis que Lacerda analisou. Sobre isso, acrescentou que tendo os resultados apontado para a pouca homogeneidade de caracteres da população, ficava provado que eles se assemelhavam aos botocudos, o que testemunhava em favor da antigüidade dos elementos etnológicos dessas tribos.

Quatrefages também concordava e elogiava o trabalho de Lacerda e Peixoto sobre os botocudos, pois os 12 crânios analisados davam um quadro detalhado das medidas, e concluía que, pelos caracteres que apresentavam, os botocudos se aproximavam da raça fóssil de Lagoa Santa e, pelos caracteres faciais, aproximavam-se da raça dos sambaquis, o que, para Quatrefages, poderia ser indício de que houvera cruzamento dessas raças. Ao fazer tantos elogios e comentários sobre as análises dos brasileiros, 
Quatrefages 'consagrava', na Academia de Ciências de Paris, uma visão científica que hierarquizava diferentes grupos sociais.

Quatrefages fez elogios também aos trabalhos arqueológicos de Ladislau Netto, mas com este não foi tão efusivo. Ele dava mostras do seu reconhecimento à atividade científica dos brasileiros, pois, em uma das cartas ao Imperador, disse:

o Brasil entra numa via de pesquisas sérias, precisas, que não dizem respeito apenas à história local, mas também a alguns dos mais curiosos problemas da humanidade. Sob este ponto de vista, o trabalho de M. Netto é o mais interessante e vai satisfazer a todos os nossos americanistas. Para mim, penso que teria, particularmente, muito a estudar nos trabalhos dos senhores Lacerda e Peixoto, que me pareceram trazer novas luzes sobre questões que são também as minhas. ${ }^{16}$

Ladislau Netto, então diretor do Museu Nacional, foi de fato uma figura fundamental do debate sobre o darwinismo no Brasil, porém, diferentemente de Lacerda e Peixoto, manifestava-se muito ambiguamente sobre a questão da evolução. Netto, que havia se especializado em botânica, quando o debate sobre o evolucionismo começou a se disseminar, passou a trabalhar nas franjas científicas da arqueologia e da antropologia dos índios do Brasil (Castro Faria, 1949). Entretanto, ele iniciou sua discussão sobre a teoria da evolução em um trabalho sobre botânica.

Em 1876, quando lançou o primeiro número dos Archivos do Museu Nacional, Ladislau Netto ali publicou um artigo intitulado "Estudos sobre a evolução morfológica dos tecidos nos caules sarmentosos" (Netto, 1876: 27), no qual se mostrou simpático às teorias transformistas sem ser essencialmente um darwinista.

Demonstrando familiaridade com os então recentes trabalhos dos biólogos alemães sobre morfologia evolutiva, como, entre outros, os de Carl Nägeli - um adepto do evolucionismo, mas não do darwinismo - e de Julius Sachs - um defensor das idéias de Darwin -, além do trabalho do próprio Darwin no artigo sobre os movimentos das plantas trepadeiras, de $1865,{ }^{17}$ Netto comparou suas observações com as desses autores chegando às suas próprias conclusões sobre a evolução morfológica dessas plantas. Em sua visão evolucionista, sustentou pontos convergentes com a teoria lamarckista, como 'herança progressiva' ou 'necessidade de se adaptar ao meio', afirmando em uma das passagens do trabalho: 
os sarmentosos são plantas que deviam ter tido primitivamente proporções iguais as dos mais vigorosos e desenvolvidos arbúsculos hoje conhecidos, e que habitando as florestas sombrias e compactas das primeiras idades da flora atual, onde não lhes era possível o gozo da luz direta do sol, distenderam-se por uma constante e aturada do caule para o só crescimento longitudinal, até que dado lhes foi atingir a copa do arvoredo e expor com as dele suas folhas e vergonteas à elaboração da seiva de que são agentes imediatos os raios solares. (Netto, 1876: 30)

Netto discordou de Darwin quanto à origem das plantas trepadeiras, dizendo que o autor de $A$ Origem das Espécies acreditava terem sido primitivamente volúveis todas essas plantas, sendo que as que possuíam atualmente apenas o movimento revolutivo nos órgãos foliáceos e axilares mais ou menos modificados seriam transformações desse tipo original. Para Ladislau Netto esta explicação não era satisfatória, embora satisfizesse a doutrina evolutiva (leia-se darwinista). Ele, observando tantas centenas de espécies de caules sarmentosos, via que essa incompleta ou imperfeita volubilidade dos caules eretos era vestígio de sua franca espiralização, no que concordava com Darwin, mas não aceitava a hipótese de que, por inaptidão orgânica ou por uma espécie de idiossincrasia, não se pudesse submeter esses caules à forma helicoidal dos outros, fazendo unicamente os órgãos de tais plantas que mais facilmente podiam se transformar em gavinhas e isso exageradamente, por "uma lei compensadora e naturalíssima nos preceitos da evolução" (Netto, 1876: 134).

Neste mesmo ano de 1876 , durante a sua aula de botânica no Curso Público, oferecido pelo Museu Nacional, fez duras alusões ao trabalho sobre plantas insectívoras apresentado por Darwin e Hooker na British Association of Belfast, em 1874.

Segundo o redator da Revista de Horticultura, Frederico Albuquerque, Netto teria afirmado que os dois naturalistas ingleses foram exagerados em suas observações para defender suas idéias evolucionistas, chamando-os inclusive de charlatães (Albuquerque, 1876: 63). A postura crítica de Netto em relação ao trabalho de Darwin e Hooker fez com que Albuquerque iniciasse duros ataques a ele e às suas preleções botânicas, proferidas durante os anos seguintes. ${ }^{18}$ Porém, é preciso observar que Ladislau Netto, em 1878, quando publicou o programa do seu curso de botânica no Archivos do Museu Nacional, numa das passagens em que falou da evolução, mostrou-se adepto das idéias de Haeckel: "a identidade de construtura que oferecem todas as células, tanto vegetais como animais, justifica no mais alto grau a perfectibilidade da doutrina evolutiva que lhes dá o reino dos Protistas" (Neto, 1878: 193). 
No mesmo programa disse que na luta pela vida - stuggle for life -, os vegetais se transformavam conforme as suas 'predisposições' e que a adaptabilidade era a base das leis transformistas, enfatizando, como já o fizera anteriormente, o domínio da influência do meio físico na evolução. Numa outra passagem do mesmo resumo, em que falou novamente da "luta pela vida" dos vegetais, Netto (1878: 198) escreveu:

Os vegetais armados deste modo pela natureza para a luta pela vida são os Alexandres e os Napoleões do mundo vegetativo; deu-lhes o Criador toda a energia dos conquistadores e não há de cortar-lhes o passo, como o demonstra a 'Eichornia azurea', a qual sob o nome de 'dama do lago', na Bahia, e de 'baronesa', nas Alagoas, há causado os maiores danos aos rios do litoral daquelas províncias.

Da mesma forma ambígua em relação à evolução, Ladislau Netto manifestou-se na Argentina em 1882. Nesta ocasião, fora homenageado com uma sessão especial pela Sociedade Científica Argentina. Em Buenos Aires, Netto foi obrigado a falar sobre a teoria da evolução, pois um jornal argentino, às vésperas de sua fala, anunciou que ele daria uma conferência sobre o transformismo. Ladislau Netto, em carta que escreveu ao dr. Baillon, ${ }^{19}$ na França, disse ter sido apanhado de supresa pela notícia do jornal, porque os seus amigos argentinos haviam lhe pedido para expor algumas idéias sobre a arqueologia do interior sul-americano, tema que ele vinha se ocupando desde 1869. Para ele, isso era um inexplicável malentendido, não somente porque estava desprevinido, mas também porque o assunto escolhido não era precisamente o que ele trabalhava nesta época. ${ }^{20}$ Na conferência, ele afirmou:

A doutrina da evolução, que espanta a ignorância, irritando a superstição do fanatismo, vai ganhando terreno no campo dos refratários ao invés de novas legiōes de ciência que, com crescente entusiasmo, professam, porque é a mais lógica, a mais natural, e por isso mesmo a mais atrativa de todas quantas até agora se apresentaram para explicar a admirável epopéia da criação. (Netto, 1882: 2)

Assim, ia aliando evolução e criação e, numa passagem em que explicava os seus trabalhos botânicos, definia melhor a sua idéia de evolução:

$A$ adaptação dos animais e das plantas aos meios em que vivem, ou melhor, para a energia e recursos morfológicos e fisiológicos de que dispõem na luta pela vida são, às vezes, a origem destas profundas modificações.(...) A nutriçãoe o clima, que tanta influência exercem sobre a natureza do homem e dos 
animais, e que podem ser consideradas como as bases principais da adaptação de cada indivíduo à existência que é obrigado a aceitar, tem igualmente grande valor nas condições biológicas das plantas. A 'struggle for life' é um fatal atributo de todos os vivos. A diferença consiste unicamente no gênero dos combates, que são sempre de acordo com as circunstâncias e com a configuração dos combatentes. (Netto, 1882: 6-7-Grifos nossos)

E Ladislau terminava dizendo: "Diante destes exemplos tão demonstrativos da natureza, deveríamos procurar por meio da cultura da inteligência e pelo desenvolvimento das leis sociológicas, romper as cadeias que nos escravizam ainda ao resto da criação!" (Netto, 1882: 21).

Netto, desse modo, manifestava, na conclusão do seu discurso na Argentina, sua preocupacão com a 'evolução social'. De fato, na década seguinte, nos anos de 1880 , Ladislau Netto pareceu esquecer sua especialidade em botânica e passou a dedicar sua atenção aos estudos arqueológicos, vendo-os como suporte da antropologia. Na mesma carta a Baillon, ele lamentou deixar um campo seguro de pesquisas, como a botânica, para se dedicar ao estudo das populações indígenas, afirmando que o cargo de Diretor do Museu Nacional lhe impunha o dever dessa decisão; ele afirmava que essa era a única instituição científica brasileira em estado de recolher e estudar "os despojos dos últimos representantes de muitos milhares de indivíduos que povoaram durante séculos a costa e as planícies do interior do Brasil". Justificava tal necessidade dizendo que restavam algumas centenas de descendentes "destes antigos mestres da América do Sul" (Netto, 1883: 3), que ainda poderiam dar uma idéia, mesmo que fraca, de seus ancestrais. Porém, morrendo, como morria, um grande número por ano, rapidamente a raça desapareceria completamente ou fundir-seia, formando uma imensa mestiçagem.

Já desapareceram numerosas tribos e com elas sua língua, suas cerimônias bárbaras, suas tradições e muitos outros documentos que seriam hoje para nós tão preciosas bases de estudo etnográfico. É preciso portanto que nos atemos a salvar o pouco que resta, para não sermos condenados por nossos sucessores, como dizemos agora que nossos predecessores negligenciaram o passado. (Netto, 1883: 3)

Em 1882, no mesmo ano em que foi à Argentina, Netto organizou, com êxito, a Exposição Antropológica Brasileira. O objetivo dessa exposição, conforme se pode ler na Introdução do Guia, "não é simplesmente expor os artefatos e documentos etnográficos relativos aos nossos indígenas, mas reuni-los num só repositório público e aí, 
como pesadas relíquias, oferecê-las ao culto da Ciência". ${ }^{21}$ Foi também dedicado à Exposição Antropológica o volume sexto do Archivos do Museu Nacional, cujos artigos foram somente sobre indígenas, sendo que, de todos, o mais longo, o que ocupou quase metade do volume, foi o do próprio Ladislau Netto versando sobre arqueologia.

Neste artigo, ele começou dizendo que o numeroso material reunido para a Exposição o havia animado a publicar suas observações sobre a arqueologia dos índigenas brasileiros, mesmo sabendo que era assunto controverso. Dizia ainda, como advertência, que olhando a etnologia do 'Novo Mundo' esta fornecia elementos contraditórios à escola poligenista americana, que tinha, segundo ele, em Agassiz o seu representante máximo. Ainda no artigo, Ladislau Netto admitia que a evolução dos 'animais quadrumanos' à perfectibilidade - os intermediários entre o homem e os animais - tinha origem em áreas muito restritas geograficamente. Tal fenômeno poderia ter acontecido com o homem em qualquer lugar da Terra. Chamava a atenção para o fato de que toda a América ainda estava por ser descoberta, mas os primeiros estudos 'dos centros de desenvolvimento intelectual primitivo', que se encontravam por todo o solo americano, já começavam pelos testemunhos da foz do Amazonas (Netto, 1885).

Esse artigo de Ladislau Netto foi, como o de Lacerda e Peixoto, elogiado na Academia de Ciências de Paris por Quatrefages, tanto mais pela cautela com que apresentava as suas conclusões sobre a origem do povo americano. Quatrefages não se posicionava, tampouco, sobre as evidências que Netto acreditava estar revelando a respeito da origem oriental das antigas populações que habitaram a montanha de Pacoval, ilha de Marajó, no Amazonas.

Analisando as relíquias arqueológicas encontradas, Netto verificou que as inscrições simbólicas das cerâmicas davam-lhe elementos comparativos com outras culturas, levando-o a concluir que os povos que habitaram aquele lugar possuíam uma inteligência superior que podia ter decaído em função do meio e muito provavelmente haviam migrado da Ásia para os Estados Unidos e daí desceram até chegar a Pacoval. Ele explicou também que nas formas de cabeças de marajoarenses, apresentadas na exposição, havia verdadeiros símios. Assim, resolveu colocá-las ao julgamento público na Exposição Antropológica:

A razão que me induziu a colocá-los naquela seção baseia-se na convencionalidade em que, ao meu supor, costumavam os 'mound-builders' de Marajó representar os seus próprios conterrâneos, dando-lhe com os 
caracteres físicos, as afinidades ou analogias homonímicas, pelas quais se prendiam aqueles a certos animais e em particular aos símios que eles supunham seus iguais, senão seus superiores em inteligência. (...) tentaram gravar ou pintar os simulacros da face humana, acrescendo que, se aos povos da América sempre lhes andou pela mente a suposição de haverem ascendido de qualquer classe de animais, (...) é fato averiguado que no geral acreditavam ligá-los maior parentesco ao símios. (Netto, 1885: 379)

Ladislau Netto chegava à conclusão de que os próprios índios teriam acreditado na sua ascendência simiesca; porém, fez diversas analogias com as representações zoomórficas, que se encontravam, em geral, em todas as culturas antigas, daí também poder ele afirmar que os antigos habitantes de Pacoval descendiam de uma cultura superior.

A esta sua última afirmação, Quatrefages deu mostras de ter ignorado quando elogiou o trabalho, respondendo que um certo número de sinais pintados sobre os objetos de Pacoval the pareceu ter mais significação hieroglífica, o que de fato fazia pensar nas migrações. Porém, dizia Quatrefages, quanto à origem, ou à nação mais ou menos civilizada que teria povoado a ilha, não é ainda possível afirmar nada a respeito (Quatrefages, 1885: 470).

Ladislau Netto, que não se valia dos métodos craniométricos, mas fazia analogias com a simbologia inscrita em objetos arqueológicos de diferentes países, não admitia comparar os índios a bestas. Para ele, os antigos habitantes do país descendiam de uma cultura superior.

Em 1888, Ladislau Netto participou do Congresso de Americanistas, realizado em Berlim, no qual presidiu uma das sessões e depois foi distinguido com uma homenagem do Imperador alemão. Comunicando, mais tarde, o fato ao ministro do governo brasileiro dizia: "coube-me a honra de presidir a uma das sessões daquele memorável certame científico e de expor ali pesquisas e idéias benevolentes acolhidas a respeito do caráter paleoetnológico das nações precolombianas do vale do Amazonas". (Netto, 1891a: 1) Nesse artigo, ele deixou apenas entrever seus métodos de pesquisa, mas não discutiu a questão do evolucionismo; contudo, comentou que, no mesmo congresso, esteve em contato com o professor italiano Vicenzo Grossi, que tinha se interessado pelas suas pesquisas no Amazonas.

A posição ambígua de Ladislau Netto, menos darwinista do que evolucionista, certamente contribuiu para não fechar o Museu Nacional ao debate. Além da publicação dos trabalhos de Fritz Müller nos Archivos do Museu Nacional, havia outros simpatizantes da teoria darwinista na instituição, como João Joaquim Pizarro, diretor da Seção de Zoologia. 
Este, em 1876, publicou um artigo nos Archivos que tratava da classificação e morfologia de um exemplar de Batrachychthis remetido do Paraguai ao Museu. Pizarro dedicou o artigo à atenção dos professores Darwin, Haeckel e Charles Martins (Pizarro, 1876).

Pizarro era, de fato, um simpatizante da teoria darwinista, pois, como chamou atenção Lacerda no seu Fastos do Museu Nacional (1905), costumava escandalizar as senhoras por ocasião dos Cursos Públicos do Museu, nos quais dava suas palestras sobre a teoria da evolução e enfatizava as semelhanças entre o homem e o macaco. Os trabalhos de Pizarro, no Museu, se encerraram em 1883, quando ele se aposentou. ${ }^{22}$

\section{Os Derivados do Darwinismo: haeckelianos e spencerianos}

Uma característica cultural dos anos 1870 foi o surgimento dos chamados cursos públicos no Rio de Janeiro. O Museu Nacional inaugurou o seu em 1876. Pouco antes, em 1873, tinham surgido as Conferências Populares da Glória, que foram tribunas tanto para a defesa quanto para o combate às idéias darwinistas. Em defesa do darwinismo, partiu o médico, Augusto Cezar de Miranda de Azevedo, formado pela Faculdade de Medicina do Rio de Janeiro, que expôs ao público a concepção biológica de Darwin, sob o ponto de vista do monismo haeckeliano (Collichio, 1888). Para ele, "Darwin foi, no terreno zoológico e botânico o revolucionário que produziu a mesma reforma que Lyell na geologia, assim baqueou nas ciências naturais a absurda hipótese teleológica sustentada por Cuvier e ultimamente por Louis Agassiz" (Azevedo, 1876: 42).

Miranda Azevedo já havia manifestado sua posição favorável à teoria de Darwin por ocasião de sua prova na defesa de tese na Faculdade de Medicina do Rio de Janeiro, em 1874. Nessa ocasião, discorreu sobre o tema: "Do Darwinismo - é aceitável o aperfeiçoamento cada vez mais completo das espécies até o homem?" -, no qual defendeu amplamente a teoria (Collichio, 1988: 35). Desde então, passou a divulgar as idéias de Darwin e Haeckel, proferindo, no ano de 1875, nada menos do que sete conferências sobre esse tema nas Conferências da Glória: "O Darwinismo seu passado, seu presente, seu futuro" (2 vezes); "Estudo e demonstração das Leis fundamentais do darwinismo"; "Os diversos meios de reprodução do organismo"; "Sobre a fecundação dos organismos animais"; "Sistema de Darwin"; "Aplicação da doutrina evolutiva do homem" (Fonseca, 1996). 
Além de Miranda Azevedo, outros conferencistas usaram a tribuna da Glória para se posicionarem sobre a teoria de Darwin, como, por exemplo, Feliciano Pinheiro de Bittencourt, que proferiu uma palestra, em 1876, sobre o darwinismo, cujo resumo foi publicado no Diário do Rio de Janeiro (Fonseca, 1996).

Uma nota do autor sobre essa conferência dizia que, ao ter tratado do darwinismo, isto é, da doutrina evolutiva, tinha procurado mostrar que, no estado atual da ciência, era ainda coisa irrisória afirmar que o homem descendia do macaco, ou que não era mais do que um macaco aperfeiçoado (Bittencourt, 1876).

Nessa mesma tribuna, em 1876, Antonio Felício dos Santos falou "Da moda em relação com a Hygiene", onde reportou que:

O célebre Darwin, nos últimos desenvolvimentos da teoria evolutiva, estabelecendo a descendência do homem por transformismo de tipos animais extintos, dá-nos um ascendente próximo comum com os símios. Em um dos seus últimos livros, a Expressão das Emạões, mostra engenhosamente o nosso parentesco com o nosso primo macaco atual, menos pela igualdade de conformação orgânica do que pela analogia das funções cerebrais, e sobretudo pela imitação. Sem fazer-me cargo de defender semelhante teoria, não posso deixar de concordar que esse é um dos argumentos mais especiosos em prol da hipótese do símio antropóide de Haeckel. (Santos, 1876: 109)

Santos era um heackeliano que aplaudia Darwin, porém, nas Conferências da Glória, a teoria darwinista nem sempre foi aplaudida. Houve aqueles que a chamaram de teoria subversiva.

Encontramos em Miranda Azevedo um dos mais contundentes defensores da teoria darwinista que se valeu das conferências populares para divulgá-la. Ele não somente defendeu o darwinismo, como também, através dessas idéias, defendeu a política republicana contra o Imperador, alegando que a causa principal dos problemas sociais era a ignorância daquela teoria pelos que legislam. Nesse sentido, afirmou:

Por todo mundo civilizado atualmente está grassando a preocupação do predomínio militar, e qual a causa dessa preocupação? A ignorância nas leis de Darwin na maneira porque são confeccionadas as legislações militares. Procuram para o exército os entes sadios, fortes, vigorosos e desprezam, deixam para constituir a familia, para organizar sociedade aqueles que têm defeitos, que são fracos fisicamente. Qual a consequência desse fato? A consequência lógica e imediata de uma lei de Darwin da hereditariedade. (...) Não será muito mais vantajoso conformarmo-nos às consequências das teorias de Darwin do que formularmos odiosas leis militares que só servem para armar o despotismo e os caprichos dos que governam?". (Azevedo, 1876:41) 
Miranda de Azevedo seguiu em sua exposição chamando a atenção para as consequências positivas que se poderiam adquirir na educação da mocidade e na felicidade dos povos com o estudo das leis de Darwin, evitando assim que se 'produzisse um país presa do despotismo e das classes privilegiadas'. Essas idéias que, como bem frisou Collichio (1988: 35), refletem os pressupostos do darwinismo haeckeliano, como transmissão hereditária dos caracteres adquiridos, deixam entrever também a questão social da idéia de aperfeiçoamento das raças.

De fato, nas teses de Miranda de Azevedo pode-se perceber as linhas gerais das idéias que viriam fundamentar o que se chamou darwinismo social. Nos últimos anos do século XIX, ao lado das teses da Faculdade de Medicina do Rio de Janeiro, onde se discutia a teoria, começaram a aparecer trabalhos de intelectuais formados na Escola de Direito de Recife, como os de Sylvio Romero e os de Tobias Barreto, baseados no evolucionismo professado por Spencer e Haeckel. ${ }^{23}$ Recife havia se tornado um centro de difusão da cultura germânica onde se mantinha um jornal publicado em alemão, dirigido por Tobias Barreto. Lá, foram as idéias de Haeckel que ganharam maior expressão, além das de Spencer propagadas por Sylvio Romero.

Como seguidor do evolucionismo spenceriano, Sylvio Romero, em 1888, queria fazer uma genealogia da sociedade brasileira seguindo as diretrizes da teoria de Darwin. Para ele, "a história de um povo deveria fornecer uma explicação completa da sua marcha evolutiva" (Romero, 1949: 43). Assim,

uma teoria da evolução histórica do Brasil deveria elucidar entre nós a ação do meio físico por todas as suas faces, com fatos positivos não por simples frases feitas; estudar as qualidades etnológicas das raças que nos constituíram; consignar as condições biológicas e econômicas em que se acharam os povos para aqui emigrados nos primeiros tempos da conquista; determinar quais os hábitos antigos que se estiolaram por inúteis e irrealizáveis, como órgãos atrofiados pela falta de função; acompanhar o advento das populações enraizadas e suas predisposições; descobrir assim suas qualidades e tendências recentes que foram despertando; descrever os novos incentivos da psicologia nacional que se iniciaram no organismo social e determinaram-lhe a marcha futura. De todas as teorias propostas a de Spencer é a que mais se aproximou do alvo. (Romero, 1949: 54)

Em uma nota de pé de página, ele acrescentou que semelhante interpretação 'à la Darwin' era adotada em seus livros: Literatura Brasileira e a Crítica Moderna, Estudos sobre a Poesia Popular no Brasil e História da Literatura Brasileira (Romero, 1949: 54). Romero era um adepto da 
mestiçagem e acreditava que a sociedade brasileira, no futuro, seria 'branca', o. que, segundo ele, percebia-se pela sua 'história evolutiva'.

Sobre a teoria da evolução social, Sylvio Romero discutiu muito naqueles anos do final do século XIX, quando publicou um grande artigo na Revista Brasileira intitulado "O kaeckelismo em sociologia" (1899), numa clara alusão à inviabilidade da aplicação da teoria à evolução social. Ele lembrou que a aplicação da teoria de Darwin na história, na lingüística, no direito, na moral e na sociologia em geral datava de mais de 20 anos; enumerou os estudos jurídicos que a aplicavam no Brasil, como os de Tobias Barreto, Arthur Orlando, Clóvis Bevilácqua ou Martins Júnior, dizendo que eles falavam, em seus estudos, de uma ontogênese e de uma filogênese do direito e da sociedade.

Para Sylvio Romero (1899: 201 - Grifos do autor), no entanto, a fórmula haeckeliana - "Cada povo que se desenvolve recapitula as fases anteriores da evolução da espécie humana" - aplicada à sociedade era exagerada e não muito acertada. Ele discordava também de outra lei sociológica que dizia:

Sempre que uma sociedade se desloca de uma região para outra e o grupo civilizado se põe em contato e fusão com gentes em períodos inferiores de cultura, a história volta séculos atrás e passa a recapitular sumariamente as fases passadas da história da humanidade. (1899: 201 -Grifos nossos)

Sylvio Romero se declarou identificado com o darwinismo poligenista e as teorias biológicas que aceitavam uma analogia entre animais e vegetais, como a de Tarde. Retomou as idéias de Spencer e a tese de Schäffe, concluindo que as 'raças', por mais estranhas que sejam, mostram um 'paralelismo analógico' nas várias fases do seu desenvolvimento, e os estágios percorridos pelas civilizações de alta cultura e a reprodução da filogênese e pela ontogênese é coisa explicável, em alguns casos, pela identidade da natureza humana, fundamentalmente a mesma por toda parte. Noutros casos, pode ser explicada pela similitude dos meios geográficos em várias regiões, capazes de excitar a produção das mesmas idéias e tendências e, finalmente, por imitação e adoção de concepções alheias. Dizia ainda que um povo comparado consigo mesmo nos vários momentos de sua própria evolução pode aqui e ali passar por similitudes mais ou menos profundas, não se repetindo, mas desdobrando-se.

Nos últimos anos do século XIX, o debate sobre o evolucionismo cresceu muito no Brasil e, tal como as conclusões de Romero, que pareciam contrariar 
não somente algumas interpretações 'darwinistas' da sociedade, as conclusões da antropologia herdeira de Quatrefages ou a de Ladislau Netto (para quem o meio causara a decadência da 'cultura superior') ganharam espaço. Mas essas interpretações não foram as únicas que surgiram.

A Revista Brasileira, publicada no Rio de Janeiro, mostrou que na década de 90 do século XIX, além das conclusões de Romero sobre os exageros da interpretação do haeckelianismo social, mais um debate surgiu sobre a ascendência do macaco ao homem. Este se deu em torno do estudo de Dubois sobre o Pithecanthropus e travou-se entre Hermann von Ihering, diretor do Museu Paulista, e o zoólogo Carlos Euler, um adepto de Haeckel, que dizia ser impossível negar que as descobertas de Java tivessem diminuído a distância entre o homem e o macaco (Euler, 1987a). Ao contrário, Ihering, um amigo de Virchow e partidário do método craniométrico, dizia que não havia ainda uma conclusão sobre o fóssil do Pithecanthropus, visto que os mais competentes naturalistas não haviam chegado a um consenso e, para ele, aquele fóssil era pequeno demais para ser de um homem e grande demais para ser de um antropóide (Ihering, 1987).

A questão da descendência humana do macaco aparecera tempos antes no Jornal do Comércio do Rio de Janeiro, em que, sob artigo intitulado "A teoria darwinista", de autor anônimo, eram apresentadas as experiências de Robinson, na Inglaterra, que, comparando o instinto do macaco e do bebê de agarrar-se a mãe, concluíra serem ambos semelhantes, o que provava a descendência ou pelo menos deixava claro que 'éramos muito semelhantes'. ${ }^{24}$

Na Revista Brasileira, eram discutidos, além dos aspectos sociais do darwinismo, os seus aspectos biológicos, como o fez Carlos Euler num artigo em que falava sobre as "flores e seus hóspedes" - explicando a relação da seleção das espécies botânicas com os insetos que se alimentavam do seu pólen e ao mesmo tempo as polinizavam (Euler, 1897b). Outro trabalho era do médico Domingos Freire, discutindo o surgimento e a evolução biológica da vida num artigo intitulado "A pátria das plantas cultivadas" (Domingos Freire, 1897). Até que ponto esses trabalhos estavam fundados em experiências concretas dos seus autores, possivelmente os estudos mais aprofundados que vêm se realizando sobre o darwinismo no Brasil nos dirão. ${ }^{25}$

Ao menos um estudo de fôlego pode-se citar, pois este tentou fazer uma grande síntese da natureza brasileira, apresentando a geografia climática, botânica, zoológica e geológica do Brasil. Foi o trabalho de Emmanuel Liais (1881), que teve como pano de fundo a teoria de Darwin 
e de Lyell. ${ }^{26}$ Liais, em seu trabalho, explicava a teoria da seleção das espécies e tocava na questão racial, cara aos brasileiros, que legalmente escravizaram os negros até 1888. Ao contra-atacar com a teoria de Darwin, contrariava os princípios da antropologia craniométrica e da arquelogia, para as quais a superioridade das culturas era medida pelo tempo da sua existência.

\section{Conclusões}

O confronto de vários autores que se envolveram com a teoria de Darwin no Brasil em fins do século XIX leva a concluir que não somente o debate sobre a teoria foi representativo naquele momento, como se instauraram polêmicas que, além de dividirem a opinião dos que com ela se envolviam, deixaram claro que no caldeirão conhecido como 'darwinismo' confundiram-se as várias interpretações da idéia de evolução.

As diferentes posições relativas à teoria de Darwin ficaram bem evidenciadas, por exemplo, no Museu Nacional, onde conviveram as teses de Müller e de Lacerda e Peixoto. Estes últimos dialogaram e ganharam o reconhecimento de Armand de Quatrefages, presidente da Academia de Ciências de Paris, ferrenho opositor de Darwin e dos que com ele se identificavam. Haeckelianos e spencerianos, como Sylvio Romero, Tobias Barreto e outros, embora se identificassem com Darwin, também não podiam ser considerados darwinistas, pois trabalhavam com variantes da teoria da seleção natural.

No Brasil, a 'introdução e recepção' do darwinismo não foi diferente de tantos outros lugares - conviveram resistência e aceitação. Para reconhecer, no entanto, quem foram os vencedores ou quem foram os vencidos é preciso ainda muitos estudos em diferentes campos científicos. $\mathrm{O}$ debate não se fechou nos idos do século XIX.

\section{Notas}

' Sobre o darwinismo entendido como um "sistema de conhecimento provido de dinamismo e maleabilidade que lhe permite mudar no tempo e no espaço", ver Glick (s.d.: 35).

2 Sobre a idéia de recepção, estilo e processo de racionalidade das ciências, ver Paty (1990). 
3 Náuplio é o estágio larvar planctônico e característico da maior parte dos crustáceos aquáticos.

4 Ver, neste livro, artigo de Papavero, intitulado "Fritz Müller e a comprovação da teoria de Darwin".

5 Archivos do Museu Nacional, v. II, 1877 (5 artigos); v.III, 1878 (4 artigos); v. IV, 1879 (5 artigos); v.VIII, 1892 (3 artigos).

- Comptes Rendus de l'Académie des Sciences de Paris, 1875: 540-541 (Arquivo da Academia) na reunião do dia 4 de março de 1875, da Academia de Ciências de Paris, houve eleição para preencher uma vaga de sócio correspondente para seção de Geografia e Navegação, em substiuição ao Almirante Wrangell. No primeiro turno da eleição, com 57 votantes, S. M. Dom Pedro, imperador do Brasil, obteve 43 votos; General Sabinte, sete votos, e o sr. Cialdi, dois votos; havia 5 votos em branco. Tendo, S. M. D. Pedro, obtido a maioria absoluta dos votos, foi proclamado correspondente. (Tradução livre)

7 A correspondência de Pedro Il está conservada no Arquivo Imperial de Petrópolis, Rio de Janeiro. É conhecido o fato de ter Pedro II financiado diversos trabalhos científicos da Europa, dentre os mais conhecidos encontra-se o financiamento a Louis Pasteur.

s Ofício de 31/07/1875 (Arquivo Museu Nacional, doc. 42, Pasta 14). Na mesma ocasião, o Imperador enviou fósseis também para Virchow na Alemanha.

- Carta de Pedro II a Quatregages: 14 de dezembro de 1878 (Arquivo de l'Academie des Sciences de Paris).

- Carta de Pedro II a Quatrefages: 06 de fevereiro de 1886 (Arquivo de l'Academie des Sciences de Paris).

I Carta de Pedro II a Quatrefages, escrita de Cannes: 17 de abril de 1891 (Arquivo de l'Academie des Sciences de Paris).

n Carta de Quatrefages a Pedro II: 2 dezembro de 1873 - o livro do qual ele fala, aparentemente, éo Instruções para os Imigrantes Estrangeiros, de Nicolau Joaquim Moreira, publicado em português e inglês para ser divulgado na Europa e Estados Unidos. Numa outra carta (Carta de Quatrefages a Pedro II: 7 de janeiro de 1876 - Arquivo Imperial de Petrópolis), invocando um trabalho de Grandidier e Milne Edwards que acabava de ser publicado, Quatrefages dizia que este significava um golpe mortal na teoria darwinista com suas pretendidas origens simiescas. Dizia que Haeckel pensara encontrar nos Lémuriens a cadeia necessária entre os marsupiais e os macacos, que ele faz nosso ancestral pelo seu intermediário, o homem pithecóide, do qual não conhecemos traço algum. Grandidier havia estudado a placenta dos Lémuriens, que Haeckel acreditava ter uma "caduque" e ser discoidal semelhante nos homens e nos macacos. Porém, Grandidier demonstrou que faltava aos Lémuriens a "caduque" e a sua placenta era difusa como as "angulles", os "edentés" e os Cetáceos.

B Carta de Quatrefages a Pedro II: 27 de abril de 1874 (Arquivo Imperial de Petrópolis).

* Os diplomas de participação na Exposição Antropológica de Paris e medalhas que ambos receberam foram expostos na Exposição Antropológica Brasileira realizada em 1882 (Guia da Exposição Antropológica Brasileira, Rio de Janeiro: Museu Nacional, 1882, p. 45 e 71 ).

s João Batista de Lacerda era médico e nessa ocasião dirigia a Seção de Anatomia Comparada e Antropologia do Museu Nacional, coadjuvado pelo também médico, Rodrigues Peixoto Filho. Lacerda, a partir de 1880, passou a intergrar o Laboratório 
de Fisiologia, então criado no Museu sob a direção de um ex-aluno de Claude Bernard, Louis Couty.

b Carta de Quatregafes a Pedro II: 11 de agosto de 1885 (Arquivo Imperial de Petrópolis).

v Ver Montgomery (1974).

* Ver Sá \& Domingues (1996).

* Na época, professor de história natural da Escola de Medicina de Paris.

v A carta a Baillon foi publicada pelo Museu Nacional, juntamente com a conferência, no ano seguinte - Aperçu sur la théorie de l'Évolution, Conférence faite à Buenos Aires dans la séance solenelle, célebrée en son honeur para la Societé Scientifique Argentine, le 25 octobre 1882, Rio de Janeiro, Imprémerie du Méssager du Brésil, 1883. Baillon, professor de história natural da Escola de Medicina de Paris, tinha sido, provavelmente, professor de Ladislau Netto.

21 Guia da Exposição Antropológica Brasileira realizada pelo Museu Nacional do Rio do Janeiro, em 1882.

$n$ Ofícios de 9 de outubro e 19 de dezembro de 1883. Arquivo Histórico do Museu Nacional, Docs. 160 e 199, Pasta 22.

23 Tobias Barreto e Sylvio Romero escreveram vários livros em que divulgaram a teoria de Darwin e foram professores; o primeiro dirigia a própria escola em Recife, onde mantinha também um jornal escrito em alemão; o segundo foi professor de filosofia do Colégio Pedro II e da Faculdade de Direito. Ver Antonio Cândido (1975).

34 A Teoria Darwinista. Jornal do Comércio, 1893.

s Lembramos especialmente o trabalho de doutoramento em andamento de Regina Gualtieri (USP).

* Liais foi um astrônomo francês contratado pelo Imperador para dirigir o Observatório Nacional em 1874. Antes, havia chefiado para o governo diversas expedições de reconhecimento geográfico do interior do país.

\section{Referências Bibliográficas}

AGASSIZ, E. C. L. Agassiz: his life and correspondence. Boston: Houghton, Mifflin, 1885, 2v.

ALBUQUERQUE, F. Curso do Museo. Revista de Horticultura, 1(4): 61-64, 1876.

AZEVEDO, A. C. de M. Darwinismo seu passado, seu presente, seu futuro. Conferencias Populares. Rio de Janerio: Typ. Imp. de Const. de J. Villeneuve, 1876.

BITTENCOURT, F. P. de. Conferências Effectuadas na Escola da Glória pelo Doutor (...).Conferências Populares. Rio de Janerio: Typ. Imp. de Const. de J. Villeneuve, 1876.

CÂNDIDO, A. Formação da Literatura Brasileira. Belo Horizonte: Itatiaia, 1975. 2v.

CASTRO, M. W. de. O Sábio e a Floresta. Rio de Janeiro: Rocco, 1992.

CASTRO FARIA, L. As Exposições Antropológicas do Museu Nacional. Rio de Janeiro: Imprensa Nacional, 1949. 
COLLICHIO, T. A. F. Miranda Azevedo e o Darwinismo no Brasil. São Paulo: Itatiaia/Edusp, 1988.

DARWIN, C. On the Origin of Species by Means of Natural Selection, or The Preservation of Favoured Races in the Struggle for Life. Cambridge, Massachusetts: Harvard University Press, 1859. (Ed. Facsimilar write introduction of Ernst Mayr)

DARWIN, C. Journal of Researches into the natural history and geology. 9.ed. Londres: Ward, Hock and Co., 1890.

DOMINGOS FREIRE, J. A pátria das plantas cultivadas. Revista Brasileira, 170-284; 216$231,1897$.

EULER, C. O Pithencanthropus. Revista Brasileira, 9: 33-42, 1897a.

EULER, C. As flores e seus hóspedes. Revista Brasileira, 93-107, 1897b.

FERREIRA, R. Bates, Darwin, Wallace e a Teoria da Evolução. São Paulo: Edusp, 1990.

FONSECA, M. R. F. As conferências populares da Glória: a divulgação do saber científico. Revista Manguinhos, 2(3): 135-166, 1995-1996.

GLICK, T. Darwin y el Darwinismo en el Uruguai y en America Latina. Uruguai: Faculdad de Humanidades y Ciencias, s.d.

IHERING, H. von. Notas e observações: o Pithecantropus. Revista Brasileira, 9: 191-192, 1987.

LACERDA, J. B. de. O homem dos sambaquis. Archivos do Museu Nacional, 6: 175-202, 1885.

LACERDA, J. B. de. Fastos do Museu Nacional. Rio de Janeiro: s.n., 1905.

LACERDA, J. B. de. \& PEIXOTO, R. Contribuição para o estudo antropológico das raças indígenas do Brasil. Archivos do Museu Nacional do Rio de Janeiro, 1: 47-75, 1876.

LLAIS, E. L'Espace Celeste ou Despcription de L'Univers (accompagnée de récits de voyages entrepris pour em completer l'étude) Paris: Garnier Frères/Libraires Éditeurs, 1881. (Publicado por ordem do Imperdor do Brasi - 1.ed., 1865. Prefácio de Babinet)

MONTGOMERY, W. M. Germany. In: GLICK, T. (Ed.) The Comparative Reception of Darwinism. Chicago: The University of Chicago Press, 1974.

MÜLLER, F. Für Darwin. Leipzig: Verlag von Wilhem Engelmann, 1864.

MÜLLER, F. Notes on some of the climbing plants near Desterro, in South America, in a letter to C. Darwin. The Journal of the Linnean Society, Botany, 9: 344-349, 1865.

MüLLER, F. Facts and Arguments for Darwin. Londres: John Murray, 1869. (Tradução de W. S. Dallas)

NETTO, L. S. M. Estudos sobre a evolução morfológica dos tecidos nos caules sarmentosos. Archivos do Museu Nacional, 1: 132-144, 1876.

NETTO, L. S. M. Resumo do curso de botânica do museu nacional, em 1878. Archivos do Museu Nacional, 3: 185-199, 1878.

NETTO, L. S. M. Observaciones sobre la Teoria de la Evolution, Leidas en la Sociedad Cientifica Argentina. Buenos Aires: Imprenta de la Nacion, 1882.

NETTO, L. S. M. Aperçu sur la thèorie de l'évolution. Rio de Janeiro: Imprémerie du Méssager du Brésil, 1883. (Conférence faite a Buenos Aires dans la séance solenelle, celebrée em son honeur para la societé scientifique argentine, le 25 octobre 1882)

NETTO, L. S. M. Investigações sobre a arqueologia brasileira. Archivos do Museu Nacional, 6: 157-544, 1885. 
NETTO, L. S. M. Jornal do Comércio, Rio de Janeiro, 13 dez. 1891a. Sessão Gazetilha

NETTO, L. S. M. Jornal do Comércio, Rio de Janeiro, 20 mar. 1891b. Sessão Gazetilha.

PATY, M. L'Analise Critique des Sciences ou Le Téatraèdre Épistemologique. Paris: L'Harmattan, 1990.

PIZARRO, J. J. Nota descriptiva de um pequeno animal extremamente curioso e denominado "Batrahchychthis". Archivos do Museu Nacional, 1: 31-35, 1876.

QUATREFAGES, A. de. Note sur l'état des sciences naturelles et de l'anthropologie au Brésil. Compte Rendu de l'Académie de Sciences de Paris, 96: 308-313, 1883. (Arquivo de l'Académie des Sciences de Paris)

QUATREFAGES, A. de. Recherches sur les populations actuelles et préhistoriques du Brésil. Archives de Musée National de Rio de Janeiro. Comptes Rendu de L'Academie de Sciences de Paris 101(2): 467-470, 1885.

RODRIGUES PEIXOTO, J. Novos Estudos Craniológicos sobre os Botocudos. Archivos do Museu Nacional, 6: 205-208, 1885.

ROMERO, S. O Kaeckelismo em sociologia. Revista Brasileira, 200-235, 1899.

ROMERO, S. História da Literatura Brasileira. 4.ed. Rio de Janeiro: Livraria José Olympio, 1949. (Tomo I - Contribuições e estudos gerais para o exato conhecimento da Literatura Brasileira)

ROQUETTE-PINTO, E. Glória sem Rumor. Rio de Janeiro: Museu Nacional, 1929.

SÁ, M. R. \& DOMINGUES, H. B. O Museu Nacional e o ensino das ciências naturais no Brasil do século XIX. Revista da Sociedade Brasileira de História da Ciência, 15: 79-87, 1996.

SANTOS, A. F. Da moda em relação com a hygiene. Conferências Populares. Rio de Janeiro: Typ. Imp. de Const. de J. Villeneuve, 1876. 


\section{Virchow e os Sambaquís Brasileíros:}

\section{um evolucionismo antidarwinista}

Luiz de Castro Faria

\section{Introdução}

Rudolf Carl Ludwig Virchow (1821-1902) foi sem dúvida um dos mais famosos cientistas europeus do século XIX. Tornou-se figura notável não só por suas investigações originais nos domínios da anatomia patológica, sobretudo da patologia celular, da antropologia biológica e da fisiologia, mas também pela sua participação intensa na vida política da sua nação - membro da Dieta da Prússia e do Reichstag alemão - e nos grandes debates que agitaram a comunidade científica internacional da época. Liberal, foi adversário político de Bismarck e também de Haeckel nas mais apaixonantes questões de biologia; foi um autor consagrado no campo intelectual e, ao mesmo tempo, ator destacado no campo do poder. ${ }^{1}$

Como professor, primeiro em Würzburg e depois em Berlim, Virchow exerceu uma influência marcante na formação de discípulos, que eram encaminhados para a pesquisa em todos os setores em que ele próprio atuava como autoridade legitimadora. Cumpre-nos lembrar que um desses discípulos foi Hermann von Ihering, que iniciou seus estudos antropológicos, dedicados particularmente a questões de craniometria, sob a influência de Rudolf Virchow.

Essa atuação se ampliava na intensa participação na vida das sociedades científicas e na direção de periódicos especializados, como os Arquivos de Anatomia e Fisiologia que ele mesmo criou em 1847 e dirigiu até o ano da sua morte. Virchow foi também o criador do Museu de Antropologia de Berlim. 
Ao comentar a apresentação do relatório de Karl von den Steinen (1885) sobre os sambaquis de Santa Catarina, disse Virchow sobre a Sociedade Berlinense de Antropologia, Etnologia e Pré-História: "Talvez não se encontre no mundo inteiro nenhuma outra Sociedade que se tenha ocupado tanto com os sambaquis brasileiros" (Virchow, 1882: 220). Em seguida, lembrou as suas próprias comunicações, apresentadas em sessões de anos anteriores a partir de 1872 .

Devemos a Virchow três trabalhos importantes a respeito de sambaquis do país, um deles com base em material de São Paulo (Santo Amaro) e dois com base em materiais de Santa Catarina (São Francisco e Joiniville). Esses trabalhos merecem atenção especial, pois oferecem dados bastante significativos sobre os procedimentos que permitiram a construção de um novo domínio do saber, uma arqueologia regional do Brasil, em um dos centros mais avançados de produção científica da Europa.

Apesar do valor indiscutível, os dados desses trabalhos não foram até agora incorporados de maneira crítica aos chamados históricos das pesquisas sobre os sambaquis. Mesmo em um trabalho que tem como objetivo expresso construir o histórico das pesquisas na área do litoral sulino - sobretudo de Santa Catarina, justamente a área que proporcionou à ciência européia do século XIX os materiais que permitiriam a formulação de problemas de investigação no domínio da arqueologia do nosso litoral só se encontra referência a um dos trabalhos de Virchow. Tal fato não significa que o trabalho tenha sido aproveitado. Faltam esclarecimentos a respeito das condições que tornavam possíveis tais pesquisas. Uma vez que o famoso cientista alemão jamais esteve no Brasil, é evidente que só poderia se interessar pela nossa arqueologia, e especialmente pelos sambaquis e os esqueletos neles encontrados, se pudesse dispor, em Berlim, de peças para estudo e informações satisfatórias sobre os achados. De fato, a prática da pesquisa nesses domínios consistia, então, nas remessas de coleções e no envio de relatórios de viagens e observações.

O nome de Virchow, sua posição privilegiada como autor consagrado e ator poderoso em termos de domínio dos meios de comunicação científica, sobrepunha-se a todos, deixando praticamente esquecidos os atores menores, aqueles que, no Brasil distante, realizavam observações de campo, recolhiam peças, organizavam coleções e promoviam remessas para o Museu de Berlim. Cabe, entretanto, a esses atores menores um mérito nada pequeno 
- seus relatórios são quase sempre objetivos, as informações sobre as coletas são pormenorizadas e graças a essa confiabilidade cientistas como Virchow puderam oferecer contribuições importantes para o novo saber em constituição.

\section{Os Sambaquis de São Francisco}

Foi o engenheiro Kreplin (1872) o primeiro a enviar do Brasil para a Sociedade Berlinense de Antropologia, Etnologia e Pré-História um relatório minucioso sobre os sambaquis de São Francisco, Santa Catarina, acompanhado de várias peças arqueológicas e de um crânio que Virchow estudaria. O relatório enviado por Kreplin abrange parte dos atuais municípios de São Francisco e Joinville. A sua exposição não é metódica e nem concisa; transmite observações colhidas no campo e fornece dados objetivos sobre um sítio bem localizado.

Kreplin percorreu as bacias dos rios Cachoeira, São Francisco, Três Barras e, provavelmente, a baía de Saguaçu. O sambaqui que descreve especificamente e do qual retirou o crânio estudado por Virchow ficava a "um quarto de hora abaixo da praça da cidade e situado no rio Cachoeira" (Kreplin, 1872: 187). A cidade a que se refere é a atual Joinville e, quanto ao sítio, trata-se com certeza do sambaqui conhecido como sambaqui do Morro do Ouro, jazida já visitada e descrita desde 1865 pelo Conde de la Hure.

Com base em fatos e observação direta, mas nem sempre localizada de maneira precisa, Kreplin apresentou uma série de conclusões de caráter geral. Verificou que na região percorrida existiam numerosos montes de conchas, nos quais se encontravam em abundância restos de peixes e ossos de diversos animais terrestres, assim como um número apreciável de esqueletos humanos. Muitas dessas jazidas já se encontravam em lugares desbravados, de fácil acesso, enquanto outras, apesar do dessecamento progressivo da região, ainda se achavam em pontos quase inacessíveis, em meio de pântanos cobertos de manguezais. As jazidas mais próximas eram distribuídas para a fabricação de cal e nesse desmonte perdiam-se esqueletos humanos e artefatos. Com relação ao estado de conservação dos esqueletos humanos, verificou-se que sempre se apresentavam extremamente frágeis e quebradiços no momento em que eram descobertos, mas que se tornavam bastante resistentes quando expostos ao ar durante certo tempo. 
É muito importante destacar o fato de que Kreplin redigiu o seu relatório com o intuito evidente de discutir algumas proposições que tinham assumido reconhecida preeminência e se constituíam em problemáticas obrigatórias, sobre as quais todos os estudiosos interessados deveriam se pronunciar (Bourdieu, 1966: 865). Kreplin considerou desde logo o problema da identificação dos sambaquis com as jazidas européias, conhecidas como 'restos de cozinha', e mostrou-se pouco inclinado a admitir essa identificação. Ele sustentou que, a seu ver, as jazidas deveriam ter outra origem; em seguida, apresentou uma série de argumentos contra a identidade dos dois tipos de jazidas, e a sua atitude não deixa a menor dúvida de que não o fez com o propósito de sustentar uma tese própria, mas, ao contrário, com o objetivo evidente de contestar outra tese geralmente aceita. Isto prova que naquela época, vale dizer em 1872, a identificação sambaqui/kjokkenmoddinger estava praticamente estabelecida de maneira clara e bastante sólida. Veremos adiante que uma outra conclusão, e essa de maior relevância, fora igualmente submetida, desde essa época, à apreciação dos arqueólogos do Velho Mundo.

Como argumentos contrários à identidade dos dois tipos de jazidas, Kreplin recorreu, de um lado, ao velho esterétipo da indolência dos indígenas. Não lhe parecia admissível que os nossos índios, "que não manifestavam nenhum prazer em trabalhar" fossem reunir em um só montículo, cada vez mais alto, as conchas dos moluscos que utilizavam como alimento (Kreplin, 1872: 188). Além de se apoiar nesse estereótipo ingênuo, Kreplin apontou, sem nenhuma base concreta, uma série de condições não comprovadas, como o número reduzido de indígenas em contraste com o volume das jazidas; a necessidade de transporte das conchas em canoas até o local onde eram amontoadas e em seguida até ao topo do pequeno monte, tudo com o evidente propósito de contrastar a grande soma de trabalho que representaria o sambaqui considerado como sítio arqueológico e a 'indolência dos índios'.

Outra indicação no sentido de que Kreplin tinha em mente discutir proposições já vulgarizadas está expressa no seguinte trecho:

Formarem estas colinas uma espécie de monumento é ainda mais improvável, visto que entre os indígenas atuais não existe o mínimo vestígio de uma tradição concernente $\mathrm{a}$ isso, e nem sequer deixaram monumentos em parte alguma, mesmo quando tinham à disposição material superior. (Kreplin, 1872: 188) 
A tese do sambaqui-monumento foi com toda a certeza difundida nos meios científicos europeus por Rath em trabalho escrito em alemão e publicado, em 1874, na revista Globus. O relatório de Kreplin é anterior a essa data, e, portanto, não poderia ter sido o artigo da Globus a sua fonte. Acontece, porém, que o próprio Rath (1884) afirma nesse artigo que desde muitos anos passados já escrevia sobre sambaquis para revistas européias. Não consegui localizar nenhum desses artigos, mas, de qualquer forma, Kreplin, no seu relatório, mostra-se empenhado em contestar uma tese que já teria, então, partidários.

Um outro dado que aproxima os trabalhos desses dois autores é a preocupação de estabelecer paralelo entre os sambaquis e os aterros sepulcrais encontrados nos campos do interior. Kreplin (1872: 187) referese a um fato merecedor da maior consideração: "Os aterros, levemente arredondados, erguidos nos campos para habitação dos índios Coroados, apenas serviam para resguardarem as suas cabanas dos perigos das inundações no tempo das chuvas". A observação dessa prática revela, sem dúvida, um aspecto ecológico da vida dessas comunidades indígenas localizadas nos campos ribeirinhos digno de sérias investigações.

Kreplin se mostra bem informado sobre as práticas funerárias dessas populações. Com o intuito de contestar o caráter de sepulcrário atribuído aos sambaquis, apresenta a seguinte consideração:

Levando-se também em conta que os índios praticam o culto dos antepassados, enterrando-os solenemente e guarnecendo esqueletos, em todas as posições possíveis, na parte mais profunda dessas colinas, é capaz de provocar as mais sérias dúvidas de que os sambaquis tenham sido para os índios simultaneamente cemitérios e local de refeições. (Kreplin, 1872: 188)

Como tivesse examinado justamente um sambaqui que se encontrava apoiado no flanco de uma colina, o chamado Morro do Ouro, pareceu-lhe inadmissivel que os índios enterrassem os seus mortos no monte de conchas e não na terra seca da colina. Levado pelo seu invencível etnocentrismo, Kreplin procurou sempre apreciar os fatos de acordo com a sua própria racionalidade. Os seus depoimentos, entretanto, são quase sempre objetivos:

Por toda parte onde os índios tiveram encontro com os brancos, o que para eles significava geralmente o encontro com a morte, procuravam levar consigo, sempre que para isso era possível, os seus mortos. Encontram-se no mato, embora raramente, sepulturas de bugres perfeitamente assinaladas e protegidas contra as feras; são cercadas de diversas espécies de arbustos, cuja ramagem era entrelaçada. Pelo crescimento natural dessa vegetação o acesso tornava-se difícil e até impossível. (Kreplin, 1872: 188) 
Apesar de todas as suas dúvidas com relação ao reconhecimento dos sambaquis como 'restos de cozinha' ou como verdadeiros monumentos funerários, Kreplin não se mostra absolutamente seguro de sua origem natural. Acha, pelo contrário, muito duvidoso que se tivessem formado 'pela ação violenta das águas', e a sua atitude, em suma, é apenas de insatisfação diante das explicações propostas para os diferentes fatos observados.

Sobre o sambaqui do rio Cachoeira que, pelos dados fornecidos, identificamos como o sambaqui hoje conhecido como sambaqui do Morro do Ouro, Kreplin fornece alguns informes objetivos. A jazida teria, no momento da sua observação, pouco mais de treze metros de altura e cerca de cem de diâmetro; era composta, sobretudo, de 'ostra de mergulho', espécie identificada pelo malacologista von Martens, que examinara o material enviado para Berlim, como Ostrea parasitica, e de Venus macrodon e Cerithium atratum. Esses nomes figuram no texto de 1872 e, evidentemente, devem ser atualizados, pois a sistemática de moluscos foi revista muitas vezes, sofrendo profundas modificações. O importante é que von Martens faz também questão de esclarecer: são todas elas "espécies brasileiras atuais" e pertencem a gêneros "que em vários países servem de alimentação aos homens". ${ }^{2}$

Foi nesse sambaqui, na profundidade de cerca de 50 centímetros, que Kreplin encontrou o esqueleto cujas partes mais resistentes, inclusive o crânio, remeteu a Berlim, onde o material foi estudado por Virchow. Kreplin declarou ter comprovado a existência, nessa mesma jazida, de esqueletos humanos jazendo nos níveis de $3,86 \mathrm{~m}$ a $4,95 \mathrm{~m}$. Juntamente com o material ósseo humano, foram remetidos para Berlim alguns machados de pedra e fragmentos de ossos chatos que Virchow identificou como de costelas de baleia, ossos de peixe, sobretudo do gênero Ephippus, e ainda ossos de mamíferos terrestres. Note-se que a identificação desse gênero em material proveniente de sambaqui e divulgada há mais de cem anos tem inegável importância.

$\mathrm{Na}$ nomenclatura atual, é reconhecida a existência de uma Família Ephippidae, na qual está incluída a espécie Chaetodipterus faber, encontrada em toda a costa do Brasil, que tem o nome popular de 'enxada'. É um comedor de moluscos, como outro peixe cuja presença também vem sendo assinalada, desde o século XIX, em materiais colhidos em sambaquis, o Pogonias chromis, que na nomenclatura popular é chamado piraúna ou miragaia, este último nome de uso quase exclusivo no sul. 
Juntamente com o relatório de Kreplin, foi apresentado à Sociedade Berlinense de Antropologia, Etnologia e Pré-História, na sessão de 11 de março de 1872, o estudo craniológico completo, feito por Virchow (1872), da peça proveniente do sambaqui do rio Cachoeira ou sambaqui do Morro do Ouro, em Joinville. Nesse estudo, tanto a análise cranoscópica quanto os dados craniológicos suscitaram um grande interesse. O crânio, depois da reconstituição, ficou quase perfeito, com exceção da parte basal, e deu a Virchow condições de pesquisa bastante satisfatórias, pois ele já era um especialista em morfologia humana comparativa, de sorte que o registro dos fatos observados na peça objeto de análise tornou-se um registro relacional largamente difundido.

Com fundamento na análise bem feita de um único crânio, fica, desde a data bastante recuada de 1872 , estabelecido um certo cânone para a descrição caracterizadora dos crânios humanos provenientes de sambaquis - espessura dos ossos, inserções musculares muito pronunciadas, grande desgaste dentário. Sobre esta última particularidade, diz textualmente Virchow (1872: 190):

os dentes muito gastos, mas sem doença; apenas na raiz do terceiro molar superior direito uma grande usura, que ia até a borda do alvéolo. Nos molares da mandibula a borda posterior é mais alta e a superfície escavada; nos incisivos as bordas internas são mais baixas.

Com relação à morfologia craniana, Virchow não se limitou a constatar que tinha em mãos um exemplar de 'hipsibraquicefalia', mas tentou explicar: "Este grande desenvolvimento em altura deve-se atribuir principalmente ao grande desenvolvimento do osso frontal e, sobretudo, à escame occipital, visto que os extremos da sutura sagital se aproximam, considerados em relação ao eixo transversal" (1872: 191).

Embora cauteloso, Virchow (1872: 191) procurou estabelecer correlações com outros achados arqueológicos:

Em face do pouco conhecimento que temos dos ameríndios do sul é de certo justificável abster-nos de enunciar um juízo sobre a raça a que pertencera o crânio. Quero lembrar apenas que as figuras que aparecem num trabalho publicado por Srobel sobre Paraderos pré-históricos da Patagônia (Atti della Societá Italiana di Scienza Natural, v.X, fasc. II), mostram crânios que também poderiam ser classificados como hipsibraquicéfalos.

Com essa observação, Virchow, na realidade, impôs uma questão que daí por diante não poderia mais deixar de ser considerada. No campo 
da produção erudita do século XIX, a arqueologia e a antropologia conquistavam um espaço cada vez maior e mais bem trabalhado, e as problemáticas obrigatórias faziam aprofundar os debates de alguns temas mais vivos como a craniologia.

É interessante observar que Virchow encerrou a sua análise craniológica com uma nota judiciosa sobre a origem dos sambaquis. Ele considerou necessário aguardar novas pesquisas antes de formular um julgamento definitivo, mas lembrou que jazidas desse mesmo tipo eram conhecidas na Patagônia e nos arredores de Buenos Aires. A presença de esqueletos humanos e de artefatos, a seu ver, falava claramente a favor da origem artificial. A explicação para o fato de esses 'restos de cozinha' serem persistentemente acumulados em um só lugar parece-lhe possível, admitindo-se - e isso de acordo com informação do próprio Kreplin - que aqueles terrenos tinham sido anteriormente alagadiços a ponto de somente emergirem algumas ilhotas. Na opinião de Virchow, a hipótese poderia ser comprovada mediante o estudo sistemático do pedestal de todas essas jazidas. Certamente uma boa sugestão, dada há séculos, que ainda hoje nem sempre é levada em conta.

\section{O Sambaqui da Ilha de Santo Amaro}

Em 1874, na sessão de 10 de janeiro, Virchow volta a apresentar perante a Sociedade Berlinense de Antropologia, Etnologia e Pré-História mais um trabalho sobre material de sambaqui brasileiro.

Dessa vez foi o cônsul alemão em Santos, um certo senhor Schmidt, que por intermédio do capitão Stenzel, comandante da canhoneira Albatroz, enviou para a Alemanha um crânio e um machado de pedra provenientes de um sambaqui da Ilha de Santo Amaro. Na carta que acompanhava esse material, o cônsul Schmidt esclarecia, de maneira sumária, a proveniência:

O crânio que vai junto a esta foi encontrado num sambaqui (do qual fazem cal), nos arredores daqui. Apesar de muitas pesquisas é o segundo crânio encontrado no decorrer de dez anos, segundo me costa. O machado de pedra foi achado bem perto e descoberto simultaneamente. (Schmidt apud Virchow, 1874:5)

O capitão Stenzel, também em carta que endereçou à Sociedade, remetendo de Brêmen o material que lhe fora confiado em Santos, informou: 
Visto que o crânio me foi entregue pouco antes da partida de Santos, não me foi possível visitar os sambaquis. Estes se acham abaixo de Santos, na ilha de Santo de Amaro, limitada a oeste pelos rios Santos e Bertioga, e ao sul e a leste pelo mar. Esta ilha, como aliás toda a faixa litorânea naquela zona, é geralmente coberta de arbustos, principalmente de manguezais. As jazidas se encontram nas ramificações dos rios mencionados, e portanto, próximas também de Santos, a leste da ponta de Itapema. A altura, a julgar pela distância, deve medir de 30 a 40 pés. (Stenzel apud Virchow, 1874: 5)

Virchow não apenas analisou, mas comparou materiais aparentemente de uma mesma origem, pelo menos no que se refere à natureza do sítio arqueológico e da área geográfica. O machado de pedra do sambaqui da Ilha de Santo Amaro pareceu-lhe muito semelhante aos machados do sambaqui do rio Cachoeira ou do Morro do Ouro, em Joinville, e todos eram particularmente notáveis pelas proporções, muito acima do comum, naturalmente em termos de conhecimento do que se tinha até então. Parecia-lhe impossível, por essa razão, mas sobretudo pela extraordinária largura, estabelecer qualquer analogia com os tipos de machado europeus.

O estudo craniológico da peça proveniente do sambaqui da Ilha de Santo Amaro é minucioso. Desse estudo, Virchow pôde também comparar e discernir melhor certas características, pois já tinha em mãos o crânio proveniente de Santa Catarina. A sua análise, fundamentada na comparação, acentuou, desde logo, que a forma do novo crânio "coincidia perfeitamente" com a de Santa Catarina (Joinville), estudada anteriormente (1872). Revendo a sua análise, percebe-se a inclusão de dados novos, que devem ser constante e progressivamente relacionados. Por exemplo, só nesse momento, Virchow avançou uma diagnose de sexo, que no trabalho anterior não chegara sequer a esboçar - o novo crânio 'diferia individual e sexualmente' do anterior, pois não se podia duvidar que o primeiro era do sexo feminino, enquanto que o segundo provinha de um homem musculoso e forte (1874: 6). A craniometria o levou a concluir que se tratava, também neste caso, de uma hipsibraquicefalia, num indivíduo com caracteres cranioscópicos muito semelhantes. Assim, Virchow afirmou (1874: 7):

Daí me parece seguir que nos achamos na presença de uma forma craniana típica, e que não foi o acaso que nos proporcionou tal crânio. Em face, além disso, de que em ambos os casos foram encontrados instrumentos iguais e crânios iguais, poderemos afirmar que estamos tratando de população paleolítica do litoral oriental da América do Sul. Estudando um pouco as 
nações dessa área verificamos que as formas branquicefálicas são muito freqüentes ainda hoje. Não é improvável, portanto, que os sambaquis provenham de tribos aparentadas com as que ainda vivem atualmente.

A existência de populações indígenas antigas - cujos esqueletos foram encontrados em sambaquis do litoral meridional - com as características cranianas expressas metricamente em termos de hipsecrania (crânio alto) e branquicrania (crânio curto) já estava, pois, comprovada desde o primeiro trabalho de Virchow em 1872.

Novamente, em 1882, tornou Virchow a se ocupar com os sambaquis do Brasil, apresentando à Sociedade Berlinense de Antropologia, Etnologia e Pré-História duas novas contribuições que lhe tinham sido encaminhadas. Nessa ocasião, lembrou aos colegas que ele já havia discutido o assunto em duas sessões anteriores, em 1872 e 1874 , e que o dr. Andree fizera o mesmo por ocasião da Reunião Geral da Sociedade Antropológica Alemã de Dresden; lembrou também que depois disso o problema havia sido investigado por Wiener (1876a, 1876b) e Fritz Müller (1876). Desse modo não resta dúvida que os sambaquis do Brasil tinham ocupado definitivamente um espaço importante no campo intelectual do último quartel do século. ${ }^{3}$

\section{Notícias dos Sambaquis de Joinville}

Os primeiros achados arqueológicos e os relatórios despretensiosos de alguns imigrantes alemães empenhados em manter contato com a pátria e servi-la na medida do possível despertaram nas sociedades científicas alemãs um grande interesse por tais 'descobertas'. A acolhida que essas sociedades deram aos materiais encontrados, aos relatórios e, sobretudo, às peças e coleções, estimularam o exercício regular de tais práticas. Os museus da época consagravam todas as formas de colecionismo, e os colonos em terras distantes encontraram nessa atividade um modo gratificante de conservar os laços de solidariedade com as pátrias e suas instituições mais nobres.

A primeira contribuição apresentada por Virchow é de indiscutível interesse. Trata-se de um trabalho escrito por von Eye, residente em Santa Catarina. Nesse relatório, de apreciável concisão e de caráter rigorosamente objetivo, o autor descreve fatos de observação pessoal realizada com bastante critério. É absolutamente lamentável que os estudiosos brasileiros não tenham até hoje apreciado devidamente a contribuição de mais este 
investigador de campo, narrador fiel de coisas pessoalmente observadas, enquanto as bibliografias se avolumam com o registro de vasto, inútil e, às vezes, jactancioso trabalho de compilação.

O dr. von Eye, que residia em Joinville, legou-nos um relato despretensioso, mas denso de informações objetivas, e só devemos lamentar que não tivesse localizado com maior rigor a jazida que lhe serviu de campo de observação. Ele nos diz apenas que pertencia ao sr. Krelling, proprietário não só do sambaqui, mas também da caieira, instalada ao lado da jazida. É claro que, para a Joinville daquela época, a propriedade do sr. Krelling, que incluía uma fábrica de cal, indicaria com absoluta segurança um lugar bem definido da pequena cidade.

A região descrita pelo dr. von Eye é a planície sedimentar, já em grande parte dessecada, por onde se estende, cada vez mais longe, a cidade de Joinville e, naturalmente, as zonas ainda alagadiças que margeiam o rio Cachoeira e bordam a baía de Saguaçu. O autor das observações exprimiase com clareza e segurança:

Quem contemplar detidamente as condiçōes naturais da parte setentrional de Santa Catarina, Província do Brasil meridional, terá a sua atenção atraída para certos outeiros cupuliformes, atualmente cobertos de densa vegetação arbórea, atingindo por vezes até 25 metros de altura, que se destacam acima da faixa costeira, alagadiça e coberta de mangue. Assemelham-se a formações naturais; dir-se-ia que fossem os derradeiros contrafortes da montanha primitiva, da Serra do Mar, que perto da costa ergue para o alto os seus picos escarpados e fantásticos. Esses montes são conhecidos entre o povo por 'montes de cal' (kalkerge) e são compostos pela acumulação de certos gêneros de conchas, soltas, que são queimadas para se obter cal, como se pratica também em outras regiões. (von Eye apud Virchow, 1882: 218)

Conforme descreveu Virchow, depois dessa observação geral, o dr. von Eye deteve-se a examinar 'minuciosamente', segundo declarou, a jazida do sr. Krelling. Então conclui: "não tardei a me convencer de que se tratava aqui de obra de mãos humanas, diversa apenas quanto à localização, mas em geral absolutamente idêntica, em todos os pormenores, aos kjokkenmoddings pré-históricos das costas européias" (Virchow, 1882: 219).

O substrato da jazida era constituído de conchas de ostras e de um molusco pequeno cordiforme, que seria certamente a Anomalocardia brasiliana. As ostras eram de tamanhos muito diferentes; havia uma de grande porte e outra menor, muito apreciada na região, conhecida popularmente pelo nome de 'ostra de Santa Catarina'. O outro molusco 
muito abundante, a Anomalocardia brasiliana, era muito consumido pela população mestiça dispersa pelo litoral, segundo o depoimento de von Eye.

Duas observações interessantes foram feitas pelo dr. von Eye a respeito das jazidas da região - na primeira, assinalou que esses montes de conchas sempre se encontravam sobre base rochosa; na segunda, destacou a perfeita brancura de certas camadas de conchas. Ele verificou, no entanto, na jazida que examinara atentamente, que essas camadas se alternavam com outras escuras, compostas, em parte, de terra e não muito extensas. Diante de um exame mais acurado - disse ele - essas camadas "se revelavam como restos de fogões outrora. A massa que os forma é composta de cinzas e de carvão, muito misturadas com espinhas de peixe" (von Eye apud Virchow, 1882: 221).

Nesse sambaqui foram encontrados diversos machados de pedra, pedras de afiar, assim como esqueletos humanos. O dr. von Eye não reconheceu sepulturas; ao contrário, julgou que os ossos se encontravam esparsos e fragmentados e admitiu a prática da antropofagia, embora ciente de que não havia notícia de tal costume entre os índios que habitavam a região, nem entre os seus antepassados. Com relação aos ossos, observou acentuada espessura das partes cranianas e, a respeito dos dentes, chamou atenção para o enorme desgaste que apresentavam. Com relação ao problema da idade de tais jazidas, a sua conclusão foi que nada poderia ser estabelecido com rigor.

Quem teria sido este dr. von Eye, residente em Joinville, Santa Catarina, em 1882? Nada conseguimos saber, além do que fica comprovado por essa sua relação com a Sociedade Berlinense de Antropologia, Etnologia e PréHistória, através de Virchow, cujo nome é o único destacado. Os autores de relatórios, os colecionadores de peças, permaneciam quase anônimos, uma vez que só tinham lugar como informantes. O discurso erudito sobre os problemas que esses materiais novos suscitavam só poderia ser produzido pelos cientistas, que se tornavam os porta-vozes desses trabalhadores de campo. Os museus disputavam as coleções, os cientistas, já consagrados, solidificavam seu renome lendo para os seus pares 'comunicações' originais sobre novas 'descobertas' que os relatórios recém-chegados do Brasil revelavam. Mas eles, os autores das 'descobertas', só serviam para informar. Este sr. von Eye prestou bons serviços e deve ser relembrado. 
Concluída a sua comunicação baseada no material do dr. von Eye, continuou Virchow (1882: 223):

Quase ao mesmo tempo recebi a visita do Sr. Stegemann que trabalhara por algum tempo em Joinville, Santa Catarina. O mesmo teve a grande gentileza de entregar-me uma grande coleção de objetos oriundos de um sambaqui das proximidades de Joinville, o mesmo, talvez, mencionado pelo sr, von Eye, e de prometer ainda mais, pois, o atual proprietário do sambaqui, um alemão, o desmonta aos poucos, para a produção de cal.

A coleção Stegemann foi apreciada minuciosamente por Virchow, que relacionou, descreveu e mesmo reproduziu as peças líticas principais. A coleção incluía utensílios de pedra, moluscos, restos ósseos de diversos animais e, finalmente, peças de esqueletos humanos. Com relação aos artefatos de pedra, observou Virchow que muitos deles revelavam simples aproveitamento de peças naturais, inclusive seixos rolados, apenas afeiçoados para o uso:

Quanto às peças que fora de qualquer dúvida são trabalhadas por mãos humanas, vê-se facilmente que bem pouco artifício foi empregado para mudá-las de sua forma natural, primitiva, em utensílios técnicos. Foram primeiro golpeadas lascadas e depois, na sua maioria, parcialmente desgastadas para dar-lhes gumes afiados. (1882: 298)

A rocha predominante seria o diorito, mas havia também peças de quartzo, quartzito, pórfiro e gabro, segundo determinação feita na época por especialista.

$\mathrm{Na}$ coleção Stegemann, encontravam-se pedras arredondadas ou ovais, perfeitamente polidas (provavelmente 'bolas'); pedras apenas arredondadas, com pequena depressão central, mais ou menos afuniladas (provavelmente quebra-côcos); vários machados de tipos diferentes, mas. principalmente quadrangulares e planos, a peça maior com 21,5 centímetros de comprimento, 11,5 de largura e 4,5 de espessura; pedras de afiar, uma delas com 87 centímetros de comprimento e 21 de largura.

$\mathrm{Na}$ bela estampa em litografia que ilustrava o texto, encontram-se reproduzidas seis das "dez peças trabalhadas mais perfeitas" (Stegmann, 1884: 384) vistas, de frente e de perfil, em um terço do tamanho natural. A coleção Stegemann parece ter constituído o primeiro conjunto relativamente representativo do equipamento material das sociedades tribais antigas que habitaram ou apenas freqüentaram regularmente o litoral de Santa Catarina. O fato de a coleção ser proveniente de um único sítio, localizado em Joinville, aumenta certamente o seu valor. 
Os moluscos da coleção foram confiados para identificação ao malacologista dr. von Martens, especialista renomado e conhecedor da fauna do moluscos do Brasil. Virchow transcreveu o relatório de von Martens, que, além de classificar as espécies representadas na coleção, fez observações do maior interesse sobre determinadas características e significações do material submetido ao seu exame.

O dr. von Martens identificou oito espécies de conchas marinhas e uma de um caramujo terrestre e apontou uma particularidade: "Várias das peças são os maiores exemplares que já vi até agora". A respeito do caramujo terrestre (referia-se à espécie Megalobulimus ovatus, na nomenclatura atual) esclarecia: "vi exposto à venda no mercado no Rio de Janeiro, como alimento. A propósito da Anomalocardia brasiliana, "a mais numerosa entre as conchas enviadas", ele acentuou que "ainda hoje em dia é consumida em grande quantidade". Finalmente conclui: "São todas espécies que ainda hoje em dia existem comprovadamente vivas, nas redondezas, por exemplo, de Desterro, ou do Rio de Janeiro, apenas as ostras não se encontram mais do mesmo tamanho, nem tamanho aproximado, segundo estou informado" (von Martens apud Virchow, 1882: 220).

Como se vê, o relatório do malacologista von Martens tem um acento muito marcado - a identificação das espécies leva imediatamente em conta: a) se elas ainda vivem hoje; b) se são comestíveis; c) se são consumidas usualmente, isto é, se aparecem no mercado. Trabalhos posteriores nem sempre fornecem dados dessa ordem e se perdem em filigranas nomenclaturais.

Faziam também parte da 'coleção Stegemann' pinças de crustáceos; ossos de diferentes espécies de peixes - sobretudo da familia Ephippidae, que é encontrada na costa do Brasil, e da espécie Chetodipterus faber - e ossos de cetáceos, especialmente vértebras caudais de boto e muitos fragmentos de ossos de baleia. Foi verificada a presença de maxilar de um pequeno roedor identificado por Nehring, zoólogo e paleontólogo alemão, como do gênero Phyllomys. "Ao todo, [conclui Virchow] são raros os restos de animais vertebrados" (1882: 223).

Não faltavam na coleção ossos humanos. O material, entretanto, além de heterogêneo, estava muito fragmentado e não permitia o estudo. Nele, pôde Virchow identificar restos de pelo menos três indivíduos. Não encontrou nesse material nenhuma característica fora do comum, a não ser a extraordinária espessura das paredes ósseas e o acentuado desgaste 
dos elementos dentários. Na metade esquerda de um maxilar, encontrou a presença de uma orla de substância óssea porosa de 5 milímetros de largura, disposta na frente do segundo pré-molar.

Outro fato digno de menção é a referência feita por Virchow (1882: 224) à presença de substância corante no material selecionado no sambaqui de Joinville:

Além dos restos humanos quero mencionar ainda objetos que indicam o emprego de tintas para a pintura. Em primeiro lugar, há uma casca de ostra grande, com 18 centímetros de comprimento, coberta inteiramente por dentro de tinta vermelha acastanhada. Várias peças com brilho ferroso escuro, talvez ligeiramente queimadas na superfície, correspondem perfeitamente, na cor, ao vermelho acastanhado. Há também um pedaço de ocre amarelo acastanhado. Tanto a cor vermelha como a amarela descoram facilmente.

Depois de notar a ausência de artefatos de osso e de qualquer vestígio de cerâmica, conclui Virchow (1882: 340):

Esses achados certamente excluem definitivamente a dúvida que se tinha antes acerca da origem dos montes de conchas, sobretudo, a que fora expressa nas comunicações do senhor Kreplin, que admite serem elas uma espécie de formação natural. Vemos pelos relatórios presentes que o centro, o núcleo do outeiro, é uma elevação natural, provavelmente uma antiga ilha no aluvião - suposição que eu aliás já expressara no meu primeiro relato. Mas os próprios outeiros, mesmo os bem altos - e o senhor Stegemann menciona uma altura de 80 pés para o sambaqui de Joinville devem ser indiscutivelmente encaradas como obra humana, não como coisa rigorosamente artificial, no verdadeiro sentido da palavra, mas como produto da atividade do homem, como autêntico kjokkenmoddings. De um modo geral o aspecto dos sambaquis deve ser semelhante ao dos montões de conchas de Portugal, sobretudo ao do Cabeça da Arruda, que descrevi na sessão de 20 de novembro de 1880.

\section{Conclusões}

Pelo menos desde 1882, data do trabalho de Virchow sobre os novos achados em sambaquis de Santa Catarina, o problema da origem dessas jazidas já estava colocado em bases absolutamente corretas. As suas advertências sobre a maneira como estavam sendo conduzidos os trabalhos de colecionamento eram muito pertinentes. Virchow lastimou, em primeiro 
lugar, a falta de perícia na coleta dos esqueletos humanos e de animais vertebrados em geral. Essas falhas de observação rigorosa, com respeito às condições de jazimento dos esqueletos humanos, a seu ver, tornava prematura qualquer conclusão sobre a prática de canibalismo, tese debatida por Wiener e aceita por von Eye. "Nenhuma das peças que examinamos", diz ele, "tinha sinais de golpes ou de abertura artificial da cavidade medular. Além disso, o sr. Kreplin fala com absoluta segurança da existência de esqueletos inteiros" (Virchow, 1882: 224).

Em face de tais dúvidas, Virchow fez um apelo aos colecionadores para apreciarem com cuidado todos esses pormenores. Da mesma forma, insistiu que a coleta de restos ósseos de qualquer natureza fosse feita com atenção, pois somente assim se poderia 'formar qualquer juízo quanto à extensão da caça', e ainda fez outra advertência digna de nota:

Como são achados cinzas e carvão em quantidade, seria de esperar que entre os carvões se tivessem conservado uma vez ou outra restos de substâncias alimentares vegetais, em formas reconhecíveis. Averiguá-lo seria importante, tanto mais que provas da existência de agricultura, embora talvez ainda muito inferior, seriam de grande significado para se poder determinar em que estado de firmeza, de seca, estava a terra, na época em que foram acumulados os montões de conchas. (Virchow, 1882: 224)

O senhor Stegemann, que levara pessoalmente a Virchow aquele apreciável conjunto de objetos colecionados em um sambaqui de Joinville, remeteu, em $1^{\circ}$ de julho de 1884, à Sociedade Berlinense de Antropologia, Etnologia e Pré-História, um relatório, no qual prestava novos esclarecimentos sobre o sambaqui em questão (Stegemann, 1884). Nesse relatório, encontramos dados objetivos que valorizam sobremodo as informações fornecidas pelo dr. von Eye e completam os informes prestados pelo próprio Stegemann, talvez, oralmente, quando da visita que fez à Sociedade Berlinense de Antropologia, comentados na última comunicação de Virchow.

O primeiro fato a registrar é que Stegemann identificou claramente a jazida na qual realizara as suas observações, e de onde obtivera o material levado para Berlim. Trata-se do mesmo 'sambaqui do senhor Krelling', nos arredores de Joinville, descrito pelo dr. von Eye, ficando assim positivada a suposição de Virchow. Igualmente importante foi o fato de que certas afirmações de Stegemann contra as do dr. von Eye pareceram inegavelmente mais corretas. O dr. von Eye, por exemplo, afirmara que as partes dos 
esqueletos se encontravam fragmentadas e dispersas, e, por isso, admitia, consoante velha representação literária, 'práticas canibalescas'. Stegemann, ao contrário, considerou que essa suposição deveria ser tomada com reservas e apresentou não só o seu testemunho, mas também o do próprio senhor Krelling, explorador da jazida para fabricação de cal, de que os esqueletos quase sempre se encontravam inteiros. Os ossos humanos, levados para a Alemanha, retirou-os ele mesmo, segundo afirmou claramente, de um local onde os esqueletos pareciam estar acocorados.

Outra observação digna de realce especial é a que se refere à possibilidade de enterramentos secundários. Com base no conhecimento que possuía de práticas semelhantes entre as tribos indígenas atuais, lembrou Stegemann que a presença de esqueletos incompletos ou fragmentados poderia resultar desse tipo de enterramento. Stegemann registrou igualmente um fato importantíssimo, a presença de um grande número de esqueletos em áreas algumas vezes bastante reduzidas. Como julgasse, além do mais, que a disposição regular das camadas de conchas, sobretudo de ostras, e a presença de artefatos de pedra, de substâncias corantes e de um número elevado de esqueletos humanos tornassem pouco provável que essas jazidas resultassem de um amontoamento 'casual', supôs uma origem bem diversa, uma vez que todos aqueles elementos, ao contrário, sugeriam uma construção 'intencional'.

Presumo, [diz ele], que os sambaquis foram locais de festa, pontos de reunião em ocasiões solenes. A precaução poderia justificar a escolha de pontos situados assim livremente, no mar ou em atalaias. Todos os sambaquis que conheço acham-se localizados em pontos de importância estratégica. Sua base é um grande rochedo. Ainda hoje todo o terreno ao redor dos sambaquis está cheio de palmeiras, prova de que o solo é pantanoso. (Stegemann, 1884: 384)

E Stegemann (1884: 385 ) avança um pouco mais:

Essa hipótese explica muita coisa, por exemplo, os múltiplos restos de substâncias corantes, certamente empregadas contra os mosquitos, $\mathrm{e}$ em parte como adorno festivo. Encontram-se camadas inteiras (transversais) de certa tinta amarela. Os montes de cinza, espinhas de peixe, etc. indicam festins, bem como o grande número da cascas de moluscos. Sobretudo compreende-se bem aparecimento de tal quantidade de esqueletos humanos em espaço tão pequeno.

Stegemann conhecia os resultados dos estudos de Wiener (1876a) e provavelmente sentia-se inclinado, em face das próprias observações, a 
identificar os sambaquis como 'sítios funerários'. As suas contribuições são realmente importantes: reconheceu as pedras arredondadas com pequenas depressões centrais entregues a Virchow, que as descreveu, sem identificar o seu uso, como 'quebra-côcos'. A presença de pedras de afiar e de peças em elaboração ou de simples matéria-prima o fez considerar que o sambaqui teria servido igualmente de local de trabalho em comum.

Stegemann, além do mais, sabia propor questões. Para ele, o problema fundamental seria esclarecer as razões que teriam levado certos grupos indígenas a se estabelecerem temporariamente e com intervalos mais ou menos regulares naqueles pontos. Embora admitindo que os pontos fossem locais de acampamento, a construção dos montes de conchas, ainda assim, parecia-lhe obra intencional e não fortuita.

\section{Notas}

1 Sobre essa questão, ver Bourdieu (1966).

2 A observação do malacologista von Martens está inserida no texto de Kreplin, apresentado por Virchow à Sociedade Berliense de Antropologia, Etnologia e Pré-História, em forma de nota (Kreplin, 1872).

3 Guilherme Schuch Capanema ao definir os sambaquis, em 1874, comentou que eles eram marco para os viajantes, embora estes nem sempre os interpretassem devidamente.

\section{Referências Bibliográficas}

BOURDIEU, P. Champ intellectuel et projet cráateur. Les Temps Modèrnes, 246: 865-906, 1966.

CAPANEMA, G. S. de B. Die sambaqui oder muschelberge brasilien. Petermann's Mitteilungen 20: 228-230, 1874. (Resumo em Geological Record, 1: 162, 1874; publicado em português: Ensaios de Sciencia, 79-89, 1876.)

KREPLIN, H. Über die muschelberge von D. Francisca (Brasilien). Zeitschrift Fuer Ethnologie, $4: 187-189,1872$.

MÜLLER, F. On brazilien kittchen middens. Nature, 80: 304-305, 1876.

RATH, C. J. F. Notícia etnológica sobre um povo que já habitou a costa do Brasil, bem como o seu interior, antes do dilúvio universal. Revista do Instituto Histórico Geográfico Brasileiro, $34: 287-298,1874$.

RATH, C. J. F. Sambaquis. Zeitschrift Fuer Ethnologie, 16: 449-452, 1884. (Publicação póstuma; manuscrito oferecido pelo dr. Carlos Rath, filho, ao redator do Jornal Alemão de Porto Alegre, provavelmente Carlos von Koseritz) 
STEGEMANN, R. Brasilianischen sambaquis. Zeitschrift Fuer Ethnologie, 16: 384-386, 1884.

STEINEN, K. V. D. Sambaquis de Santa Catarina. Jornal do Commercio, Rio de Janeiro, 19 ago. 1885. Viagens.

VIRCHOW, R. Über die muschelberge von D. Francisca (Brasilien). Zeitschrift Fuer Ethnologie, 4: 189-191, 1872 .

VIRCHOW, R. Ein schädel und ein steinbeil aus einem muschelberge der Insel Sto. Amaro. Zeitschrift Fuer Ethnologie, 6: 5-8, 1874.

VIRCHOW, R. Nehe funde aus brasilianischen muschelbergen der provinzia. Sta.Catarina, Zeitschrift Fuer Ethnologie, 14: 218-224, 1882. (Relatório do dr. A. von Eye, "residente no Brasil"; comentário a respeito das informações e das peças oferecidas à Sociedade pelo sr. Stegemann)

WIENER, C. Die sambaquis oder muschelhasen in brasilien. Das Ausland, 45: 895-897, 1876a.

WIENER, C. Estudo sobre os sambaquis do sul do Brasil. Archivos do Museu Nacional, 1: 1$20,1876 b$. 


\section{A Fundaf̧ão Rockefeller e a Emergêncía da Genética no Brasil $(1943-1960)^{1}$}

Thomas Glick

\section{Introdução}

Embora a genética clássica tenha se difundido lentamente nas escolas brasileiras de agricultura e de medicina nos anos 20 e 30 do último século, sua implantação definitiva começou somente em 1943 quando Theodosius Dobzhansky começou a pesquisar no Brasil.

Dobzhansky, um biólogo russo que imigrou para os Estados Unidos nos anos 20, introduziu um grupo de discípulos brasileiros aos métodos da genética da Drosophila e ensinou-lhes rudimentos da biologia de população e da teoria evolucionista neodarwiniana. Esta introdução expandiu-se durante o ano sabático de Dobzhansky no Brasil, em 1948-1949, provendo jovens geneticistas brasileiros de um sólido programa de pesquisa evolucionista e um canal já pronto para a publicação dos seus resultados, dos quais Dobzhansky participava. Todo o processo se iniciou sob a égide da Fundação Rockefeller, que fornecia fundos para equipamentos, auxílios para viagens e bolsas de pós-graduação para os biólogos brasileiros. No conjunto, tal fato representa uma história de sucesso da ciência na América Latina e ilustra a intervenção criativa de uma fundação dos Estados Unidos no desenvolvimento de uma disciplina científica no estrangeiro.

\section{A Genética Brasileira Pré-Dobzhansky}

Todos os antigos professores de genética no Brasil eram 'autodidatas' nesse campo. Carlos Teixeira Mendes $(1928,1931)$, professor de agricultura 
em Piracicaba, foi o primeiro brasileiro a ensinar genética mendeliana. Sua tese de 1917 sobre o aperfeiçoamento das variedades agrícolas baseouse, em parte, em De Vries, e ele começou a ensinar genética no ano seguinte. Escreveu extensivamente sobre seleção, sendo que um dos seus temas comuns foi a seleção empírica para espécies de plantas e a criação de animais, que foram entendidas em termos tipicamente lamarckianos, mas poderia na verdade ser explicada por Darwin. ${ }^{2}$

Dois colegas de Teixeira Mendes também ensinaram genética em Piracicaba. Um deles, Otávio Domingues, era professor de zootecnia e, até 1930, estava atualizado nos estudos de Drosophila da escola de Morgan. ${ }^{3}$ O outro, professor de zoologia, Salvador de Toledo Piza Jr., era contrário ao conceito de 'gene' real ou concreto. Os genes, na opinião deste professor, não eram nem formados de partículas, nem capazes de automultiplicação, mas simplesmente expressões de 'plastinemes' ou filamentos de núcleos de células. ${ }^{4}$ Piza Jr. teve um papel positivo na difusão da genética e padronizou sua terminologia técnica em português. $^{5}$

Outro autodidata, um dos que teve papel significativo na institucionalização da genética no Brasil, foi André Dreyfus, que começou ensinando genética na escola de medicina em São Paulo no final da década de 20 do último século. Ele pode ter sido o primeiro brasileiro a ter compreensão da síntese neodarwinista, pois citava Fisher em 1929, mesmo ano em que houve o Congresso de Eugenia no Rio de Janeiro, no qual ele falou que o lamarckismo devia ser abandonado, incluindo a noção favorita de que um bom ambiente teria impacto favorável sobre o perfil hereditário de uma pessoa. ${ }^{6}$

A generalização da genética chegava com força em meados dos anos 30 , quando o refugiado alemão Friedrich Brieger foi nomeado professor de citogenética em Piracicaba e quando Carlos Krug, formado em Cornell, tornou-se diretor do serviço de genética (fundado em 1929 com Edgar Taschdian como primeiro diretor) no Instituto Agronômico de Campinas. Krug ensinou genética até 1933, e Brieger começou em 1936. Brieger, na década seguinte, produziu uma importante série de artigos sobre evolução das orquídeas, e a pesquisa de Krug foi sobre a genética do café. No início dos anos 40, ambos publicaram importantes trabalhos sobre a síntese neodarwinista e o papel da genética no processo da evolução (Krug, 1940; Brieger, 1944). ${ }^{7}$

Em 1934, Dreyfus tornou-se o primeiro professor de biologia na recém-fundada Universidade de São Paulo, onde, para começar o seu mandato, deu cursos sobre genética e evolução. Esta universidade foi uma 
experiência para criar uma universidade de 'estilo americano' na América Latina, pois adotou o regime administrativo de 'tempo integral' para professores e pesquisadores, desfrutando amplo suporte da Fundação Rockefeller, cuja exigência em relação à ciência na América Latina era a absoluta insistência sobre as posições de 'tempo integral' para que os cientistas não tivessem vários empregos para sobreviver. Quando, em 1941, Dreyfus chamou a atenção de um pesquisador da Rockefeller para a América Latina, tudo estava pronto para a implantação da genética moderna.

\section{O Apostolado}

A cadeia de eventos que trouxe Theodosius Dobzhansky ao Brasil começou quando um funcionário da fundação, Harry Miller, "fez sua primeira viagem abaixo do Caribe em 1941, para fazer uma avaliação das universidades da América Latina, procurando oportunidades para ajudar no ensino e nas pesquisas em ciência natural". ${ }^{8}$ Durante a viagem ele encontrou Dreyfus e ofereceu-lhe uma bolsa para estudar nos Estados Unidos. Dreyfus estava preocupado com um substituto para seus cursos e Miller prometeu-lhe encontrar um americano para substitui-lo.

Miller pensou que Dobzhansky podia fazer esta substituição admiravelmente. Em 18 de novembro de 1942, Dobzhansky procurou Miller para discutir "seu desejo de coletar espécies de Drosophila no Vale Amazônico, uma das únicas regiões do mundo onde não havia mudança climática sazonal". Vários dias depois ele especificou ainda que gostaria "de passar nada mais do que dois ou três meses no Vale Amazônico e ir como professor visitante para o Departamento de Dreyfus". No dia seguinte, Miller dissethe que havia escrito a Dreyfus para avisá-lo sobre o desenrolar dos planos, observando que "mais um ponto a favor desta troca era que a área da genética não estava tão bem representada no Brasil", "sendo que os únicos nomes que the vinham à mente eram os de Brieger e Krug.

No dia 24, Dobzhansky já havia preparado e enviado a Miller um plano para a pesquisa de campo no Brasil, na forma de um memorando intitulado Populações Genéticas na América Latina Tropical. Depois, examinando avanços na genética quantitativa e teórica de Wright, Fisher, Haldane e Müller, Dobzhansky observou que todos os estudos de população genética, até então, restringiam-se a espécies da zona temperada do 
hemisfério norte. Todas as zonas temperadas eram marcadas por mudanças sazonais e os organismos necessitavam se adaptar a vários e diferentes ambientes em suas vidas. Porém, nada era conhecido sobre estruturas de população em países tropicais, onde havia pequena variação climática. Era importante, portanto, descobrir

Se, ou não, em espécies tipicamente tropicais, as cotas de mutação são pequenas, as cotas de migração reduzidas ao mínimo; [se] a diversificação das populações em raças locais é alta, e prossegue até uma considerável extensão em linhas não adaptativas.

Somente experimentos efetivos poderiam esclarecer essas dúvidas. ${ }^{10}$ Dobzhansky tirou amostras de coleções de Drosophila brasileiras, escolheu duas ou três para estudo intenso e transportou as culturas para Nova Iorque a fim de incrementar o trabalho. Mais tarde, ele admitiu que sua hipótese inicial - presumia que sem as flutuações sazonais não ocorreriam mudanças genéticas - estava errada (Dobzhansky apud Provine, 1986).

O que emergiu no início de 1943 como o Grand Plan de Dobzhansky era uma continuação de sua famosa série de artigos sobre a genética das populações naturais sob condições tropicais no Brasil, objetivando comparar estes resultados com seus estudos de espécies temperadas, principalmente de Drosophila.

Um pouco da história do próprio Dobzhansky colocará este plano em seu contexto histórico. O principal interesse de Dobzhansky na genética da Drosophila era o estudo da microevolução. Em 1922, ele havia percebido que, para compreendê-la, deveria adquirir informações sobre "distribuição geográfica e variabilidade entre populações, variabilidade individual entre populações e herança da variabilidade" (Provine, 1981: 11). Isto não poderia ser feito sob condições técnicas clássicas, num laboratório (como o de Morgan, onde Dobzhansky trabalhou por muitos anos), porque as espécies de Drosophila estudadas eram interestéreis. Para obter a informação que ele queria, deveriam ser estudadas as populações naturais. Estudos nos anos 20 sobre D. pseudoobscura, por vários geneticistas, clarificaram o caminho a seguir. Esta espécie e a espécie irmã, D. persimilis, eram morfologicamente idênticas, mas, reprodutivamente isoladas, tinham muitos genes em comum e também exibiam considerável variação cromossômica em toda a população. Estudos em populações naturais de pseudoobscuras ofereciam a possibilidade de construir filogenias das espécies estudadas e mudavam o locus dos estudos de microevolução da origem das espécies para o de raças (Provine, 1981). 
Assim, o significado da evolução para o estudo desta espécie de população se tornava claro para Dobzhansky - quanto mais ele viesse a entender a teoria da seleção, de Sewall Wright.

O mais flexível e eficiente meio da evolução na natureza, de acordo com a visão de Wright, acontecia quando várias espécies se subdividiam em muitas e pequenas raças locais com alguma migração, e os efeitos das seleções tanto quanto a mudança aleatória eram intermediados. A seleção seria, então, operada tanto em níveis intra quanto intergrupo (Provine, 1981: 61).

Logo que Dobzhansky percebeu que microevolução podia ser mais bem estudada por comparação de raças de Drosophila, ele mesmo coletou amostras de populações naturais, recortando um grande caminho geográfico no oeste da América, da Guatemala ao Alaska.

A oportunidade de fazer coleções das espécies brasileiras de Drosophila foi, inicialmente, a principal atração para Dobzhansky. Ainda acreditando que o principal interesse em estudar Drosophila tropical era ver se a mudança genética na região era de pequena variação sazonal, Dobzhansky escreveu para Sewall Wright em janeiro de 1943, convidando-o a ir à Nova Iorque para uma discussão sobre as suas hipóteses. Wright não pôde fazer a viagem, e alguns meses mais tarde Dobzhansky viajou de trem a Chicago para um encontro de dois dias. O encontro deve ter sido frutífero, Dobzhansky logo esqueceu o enfoque sobre a mudança genética, mas os detalhes da conversa não foram gravados. ${ }^{11}$

Logo que chegou ao Brasil, em 1943, Dobzhansky viajou incansavelmente por áreas rurais com um jovem geneticista, Crodowaldo Pavan, sentindo-se um verdadeiro 'Colombo' descobrindo a América, o que lhe parecia ser o paraíso terrestre (se Drosophila podesse ser comparada a ouro!). Ele considerou a descrição de grupos de Drosophila sobre uma ilha no Rio Negro, em 1948, mas não há dúvida de que era uma correta representação de sua primeira viagem de campo na Amazônia também:

Uma selva de enxames de 'Drosophila'. Nós chegamos numa ilha do Rio Negro e encontramos o chão coberto de frutas caídas de muitas espécies de árvores e sobre estas frutas haviam nuvens de Drosophila como eu nunca tinha visto nos meus quinze anos de colecionador de Drosophila na nature$\mathrm{za}$, nem com isca natural ou artificial. Havia seguramente milhares de indivíduos por metro quadrado na ilha, que nas minhas notas foi chamada de llha Paraíso da Drosophila. Mas até mesmo fora desta ilha, a fenomenal densidade populacional tem sido repetidamente encontrada. E existe em todas as coleções várias espécies diferentes, muitas vezes maiores do que 
encontra-se na Serra Califórnia. O problema da mosca (não Drosophila) é que pelo menos metade destas espécies encontradas são novas, e nós não encontramos tempo para descrevê-las. Ainda mais, como interpretar estas observações se até mesmo sobre as espécies comuns nós não encontramos nomes? (Dobzhansky apud Glass, 1980: 81)

Em 1943, Dobzhansky descobriu 23 novas espécies de Drosophila na breve expedição ao Amazonas, uma façanha que, nas palavras do posterior relatório brasileiro, "fez com que os brasileiros colecionassem para eles mesmos. Além de as ter enviado para a sua instituição no final do verão, com um zelo quase religioso pela nova ciência". ${ }^{12} \mathrm{O}$ curso de Dobzhansky foi um sucesso igual ou maior. Como lembrou um dos participantes:

Dobzhansky veio por três meses em 1943 e deu um excelente curso sobre evolução em português. Dreyfus, Pavan e Brito (então no segundo ano de estudos) traduziram as aulas que eram então publicadas pelo Ministério da Agricultura. Dobzhansky havia estudado português por três meses e pôde falar razoavelmente porque os sons russos são similares. (...)

Mais ou menos vinte estudantes assistiram, mas a maioria dos biólogos da Universidade de São Paulo também vieram para o curso tanto como vieram do Instituto de Biologia, Escola de Veterinária - Rocha Lima, Clemente Pereira, Zeferino Vaz, etc. Assim, o curso influenciou todos os biólogos de São Paulo. Krug, Brieger e Alcides Carvalho vieram de Piracicaba e alguns também de Campinas. ${ }^{13}$

Durante os três meses que Dobzhansky permaneceu no Brasil em 1943, como ele mesmo lembrou, falando de Dreyfus:

colocou-me sob suas asas, e decidiu usar minha visita como um meio de desenvolver seu departamento de biologia, iniciando a pesquisa genética. Sendo um homem de grande energia, fez o que pretendia fazer. Uma escola de genética apareceu no Brasil, uma escola que não existia antes, e é um verdadeiro desapontamento para mim que esta não tenha se desenvolvido, mais tarde, depois da morte de Dreyfus, tão bem quanto podia ter-se desenvolvido. ${ }^{14}$

A avaliação exageradamente pessimista de Dobzhansky, feita 20 anos mais tarde, não deve obscurecer o fato de Dreyfus tê-lo usado para despertar interesse pela genética no Brasil com a sua completa concordância com o plano. 


\section{Os Biólogos se Organizam}

Segundo Cavalcanti, um dos discípulos de Dobzhansky da geração $\mathrm{F}_{1}$ a pesquisa sobre Drosophila no Brasil pode ser compreendida em três fases. ${ }^{15}$ A primeira (1943-1948) foi completamente devotada à sistemática e morfologia. Em termos de pesquisa, o período começou com os estudos de Dobzhansky \& Pavan (1943) sobre as espécies brasileiras de Drosophila, em 1943, e terminou com um artigo de Pavan e Antonio Brito da Cunha sobre o mesmo tópico em 1947.

No Brasil, Dobzhansky identificou duas espécies que pareciam interessantes estudar, sendo que a idéia era comparar uma espécie de grande população com outra de população reduzida. As espécies selecionadas foram D. willistoni e D. prosaltans, cujas amostras ele levou para o seu laboratório em Nova Iorque, onde, ele e Boris Spassky as estudaram e prepararam grupos de experimentos. ${ }^{16}$ Aqui, o trabalho com Drosophila continuou em São Paulo e, em 1944, Cavalcanti começou um grupo similar no Rio de Janeiro com Chana Malogolowkin e Oswaldo Frota-Pessoa.

Durante o mesmo período, uma série de brasileiros passou pelo laboratório de Dobzhansky em Columbia: primeiro Pavan; depois, Brito da Cunha, Cavalcanti e Warwick Kerr e, mais tarde, Malogolowkin, Antonio Cordeiro e Frota-Pessoa. "Normalmente tínhamos pelo menos um brasileiro no laboratório, raramente dois e raramente nenhum", lembrou Dobzhansky mais tarde. ${ }^{17}$

Em seguida, veio a fase experimental, que começou com a segunda visita de Dobzhansky, em 1948-1949. Esse estágio foi quase completamente devotado a estudar a genética das populações naturais de duas espécies de Drosophila, willistoni e prosaltans, um grande e um pequeno grupo, respectivamente. Essa fase envolveu o treinamento dos geneticistas no campo; alguns deles já tinham trabalhado com ele em Nova Iorque, e logo depois criaram uma estrutura institucional de genética brasileira.

Quando Dobzhansky voltou para passar o seu ano sabático, em 19481949, estabeleceu dois grupos de trabalho em São Paulo. O primeiro foi composto por Dobzhansky, Pavan, Malogolowkin e Cavalcanti para estudar a variabilidade genética da $D$. willistoni e prosaltans. Este estudo mostrou que a freqüência dos genes letais em populações naturais era mais alta em regiões tropicais do que temperadas. O segundo grupo, que incluía Dobzhansky, Brito da Cunha, Cordeiro, Hans Burla, de Zurique, e Maria Wedel, de Buenos Aires, estudou variabilidade cromossômica. ${ }^{18}$ Este grupo 
estudou quatro espécies irmãs de Drosophila (willistone, paulistorum, tropicalis e equinoxialis). Padrões diferentes eram encontrados nos cromossomos das glândulas salivares: quando os pesquisadores tentaram cruzar as espécies, viram que eram interestéreis, embora elas fossem morfologicamente muito similares. Os padrões de freqüência de inversões nestas espécies mostraram a seleção darwiniana. O grau de variabilidade das espécies era correlato com a diversidade do meio. Willistoni, numa área seca da Bahia, tinha baixa freqüência de inversão, mas em um meio mais diverso tinha uma alta freqüência. Eles também descobriram que willistoni era ecologicamente mais versátil que tropicallis, que tinha muito menor variabilidade cromossômica.

A comparação também revelou um ponto significativo sobre as relações entre competição e origem das espécies. No Vale Amazônico, a região que apresenta um número de nichos de Drosophila muito similares, os competidores próximos são espécies irmãs. Nesses lugares onde willistoni é abundante, a variabilidade é grande. Alta variabilidade mostra a capacidade de explorar mais nichos, especialmente em vista de competição com espécies irmãs. ${ }^{19}$

Até o fim do ano de 1948, mais de 40 populações diferentes tinham sido estudadas, uma façanha que levou Dobzhansky e seus colegas brasileiros a várias partes do país, uma odisséia descrita no fascinante relatório de viagem de Dobzhansky, publicado, postumamente, com o título The Roving Naturalist (Glass, 1980). A viagem foi em barco e pelo ar: os aviões, resultado de importantíssimas apresentações fornecidas pela Força Aérea Brasileira, graças ao pai de Cavalcante, um brigadeiro.

Quando Miller pediu a Burla para avaliar os anos de pesquisa, o suíço respondeu:

É muito mais difícil para mim ter uma idéia clara dos efeitos de seu auxilio para a genética no Brasil. Ambos, Pavan e Brito da Cunha, são bons e confiáveis pesquisadores. Cavalcanti e Cordeiro construíram seus laboratórios; os sucessos das atividades de cada um ficam para o futuro, como no meu caso. A luta contra a burocracia brasileira (sic) e a necessidade de tomar conta das relações pessoais são mais uma perturbação para o desenvolvimento de um trabalho eficiente, como você certamente sabe muito melhor do que eu. Mesmo assim eu penso que a maioria das condições são agora favoráveis no Brasil. Os trabalhadores têm seus programas, eles viram o exemplo de como se comportar, eles possuem excelente equipamento óptico para o trabalho de pesquisa, laboratórios com salas aclimatadas (em São Paulo) e bons salários para auxiliares, que são mais altos que em muitos países da Europa. ${ }^{20}$ 


\section{A Importância da Pesquisa em 1948-1949}

Em um admirável e conciso relatório publicado em 1949, Dobzhansky resumiu esta fase de sua pesquisa; as idéias fundamentais eram variação e adaptabilidade, "a principal força da evolução orgânica" (Dobzhansky, 1948-49). O estudo de Drosophilae tropicais foi planejado para explorar as diferenças de tempo e 'criatividade' da evolução nos trópicos, comparando com o mesmo processo em climas temperados.

Começando em 1943 sua pesquisa com Pavan, Dobzhansky e seu grupo coletaram e examinaram 110 mil amostras individuais de 35 lugares ecológicos diversos no Brasil (Dobzhansky, 1948-49). A extrema diversidade das espécies de Drosophila em pequenas áreas vizinhas, até 30 espécies em áreas de menos de um quilômetro quadrado, sugeriu que o meio tropical continha "uma maior variedade de nichos ecológicos (oportunidades biológicas)" do que o meio temperado (1948-49: 206). A adaptação a esta diversidade de nichos pode ocorrer por duas razões: ou numerosas espécies se ajustarão ao mesmo nicho ou uma pequena parcela de espécies se tornará polimorfa para explorar uma variedade dos nichos.

Drosophila, espécie particularmente receptiva à mudança, seguiu ambas opções e os experimentos eram criados para ilustrar cada processo. Primeiro, Burla, Brito da Cunha, Cavalcanti e Pavan demonstraram a diferenciação microterritorial, na qual a comunidade antes consistia de muitas espécies em competição que foram segmentadas "em microcolônias, com um muito menor número de competidores" (Burla et al., 1950: 352).

Este estudo e outros que vieram depois provaram que diferentes populações de Drosophila demonstravam diferente gosto pelos alimentos. Pavan, Brito da Cunha e Dobzhansky coletavam Drosophila na sua alimentação natural (frutas fermentadas) e mostraram que as moscas apresentavam preferência por diferentes comidas, mas sem nenhuma especialização de dieta rígida. Para Dobzhansky não estava claro como explicar a variação da atração de alimentos, mas ele concluiu que esta flexibilidade aliviava a competição. ${ }^{21}$

No estudo citado, Burla et al. (1950) fizeram experiências de taxas de difusão, soltando moscas com uma característica mutante em um lugar próximo a São Paulo para comparar o número de mutantes e moscas selvagens de lugares dados. A experiência mostrou a propensão da Drosophila willistoni a formar colônias semi-isoladas. Estas experiências 
serviram para ilustrar a dinâmica da população de Drosophila, levando à conclusão de que a densidade de populações agregadas era maior nos trópicos do que nas florestas temperadas da Califórnia, onde Dobzhansky havia colecionado dados comparáveis. Espécies similares dividiram nichos, aproveitando-se da grande variedade de alimentos disponíveis nas florestas tropicais.

Uma outra série de experiências serviu para ilustrar a variabilidade genética ocultada na forma de polimorfismo cromossômico e para explicar as vantagens da adaptação que tal variabilidade transmitia. Polimorfismo cromossômico se refere ao fenômeno de inversão dos segmentos de cromossomos. Nessa série de experiências, o estudo-chave foi o de Cunha, Burla e Dobzhansky sobre polimorfismo cromossômico em willistoni (1950), o qual procurou explicar a importância da alta incidência de inversões cromossômicas nestas espécies: 34 diferentes inversões - "a mais flexível espécie conhecida", como Dobzhansky escreveu a Sewall Wright; pseudoobscura, a espécie de zona temperada mais estudada, tinha somente 20 inversões". ${ }^{22}$ Dobzhansky procurou descrever esta memorável variabilidade genética para a observada flexibilidade de willistoni em frutas selecionadas para comer. A versatilidade ecológica da espécie era correlata à variabilidade genética: "a quantidade do polimorfismo adaptativo presente na população de uma espécie de uma dada região é, em geral, proporcional à variedade de hábitats que a espécie domina". Então, polimorfismo cromossômico era um meio "onde a espécie tornava-se capaz de ocupar e explorar eficientemente uma variedade de nichos ecológicos no meio em que vive" (Cunha, Burla \& Dobzhansky, 1950: 234; Dobzhansky, 1948-49: 210).

Outras pesquisas logo testaram esta hipótese, com resultados discrepantes, e então Brito da Cunha e Dobzhansky publicaram um estudo adicional para esclarecer definitivamente a questão. Polimorfismo, eles reiteraram, era "um método no qual uma população pode vir a ser adaptada para um multiforme ambiente" (Cunha \& Dobzhansky, 1954: 119). As inversões eram mantidas na população, 'polimorfismo balanceado', devido à vantagem adaptativa transmitida para os heterozigotos. $O$ polimorfismo cromossômico explicava a habilidade de willistoni e suas três espécies irmãs para explorar muitos nichos similares. 
Na perspectiva de Dobzhansky, em 1950, o polimorfismo cromossômico ilustrava a característica-chave da evolução nos trópicos, chamada 'versatilidade adaptativa'. Um fato muito interessante que o levou a esta conclusão foi seu reconhecimento de que "a opinião dominante sobre a ausência de mudanças sazonais nos trópicos era uma falácia". O fato de que o meio ambiente tropical estava sujeito a mudanças mostrava que a variedade de nichos ecológicos e a complexidade do processo ecológico eram mais ricos do que inicialmente ele supunha. O meio ambiente tropical trazia mais "desvios evolucionistas" do que seu equivalente temperado. As respostas dos organismos "constituem evolução progressiva" (Dobzhansky, 1950: 217). ${ }^{23}$

Alguns anos mais tarde, falando na Academia Brasileira de Ciências, no Rio de Janeiro, Dobzhansky refletiu sobre a natureza da adaptação com os resultados da pesquisa sobre willistoni. Os traços morfológicos usados para classificar Drosophila apareciam como sendo adaptativamente neutros. $\mathrm{O}$ isolamento reprodutivo de willistoni e suas irmãs não era atribuído a um traço singular, mas a 'síndromes' de genes. Genótipos, não genes singulares, estão sujeitos à seleção natural, e seu valor adaptativo se manifesta na estrutura do fenótipo. A adaptabilidade de traços ou de grupo de traços, então, "não pode ser considerada a parte do padrão de desenvolvimento que facilita sua sobrevivência numa certa sucessão de ambientes" (Dobzhansky, 1956: 347).

Este conjunto de experiências, expresso pelos dois artigos de Dobzhansky recém-citados, é considerado como um 'pilar de sustentação' pela literatura. Três dos artigos são citados por Sewall Wright (1968-78) em seu 'summa' sobre evolução e população genética referindo-se à freqüência de distribuição e variabilidade na e entre populações naturais. ${ }^{24}$

Podemos observar também que a propensão à citação de alguns destes artigos (publicado por Science Citation Index) cresceu com o tempo. O artigo, de 1950, de Brito da Cunha, Dobzhansky e Burla sobre polimorfismo cromossômico (Cunha, Burla \& Dobzhansky, 1950) foi citado 10 vezes entre 1965-1969; 8 entre 1970-1974; 7 entre 1975-1979; subindo para 14 vezes entre 1980-1984; e permaneceu citado, em 1990, 3 vezes. Igualmente, o artigo seguinte, de 1954, de Brito da Cunha e Dobzhansky (1948-49) foi citado 7 vezes entre 1965-1969; 10 entre 1970-1974; 7 entre 1975-1979; 18 entre 1980-1984; e 3 vezes em 1990. 


\section{O Apocalipse: Angra dos Reis}

Dobzhansky fez uma terceira viagem, no verão de 1952, a Belém e uma pequena parada, em 1953, para participar da banca de concurso de Pavan. A quinta e última viagem foi um outro ano sabático em 1955-1956, "a viagem menos prazerosa de todo o grupo", na visão de Dobzhansky, "numa expedição desde o início. ${ }^{25}$ Dobzhansky, vendo do avião algumas ilhas tropicais na baía de Angra dos Reis (Rio de Janeiro), teve uma engenhosa e grandiosa idéia: "Uma tentação surgiu quase tão de repente quanto eu vi que pela primeira vez que podia utilizar alguma destas ilhas verdes como gaiolas gigantes de população para experiências com Drosophila" ${ }^{26}$

A primeira experiência que Dobzhansky previu foi ver se as inversões cromossômicas eram adaptativas, soltando na ilha moscas continentais com inversões que não existiam na população selvagem. O objetivo era ver se a inversão se mantinha no meio, por quanto tempo, com que freqüência etc. 'O que exatamente aconteceu', de acordo com Dobzhansky,

nós nunca descobrimos. Eu tenho forte suspeita de que um dos estudantes de graduação que formulara um problema subsidiário, que era soltar moscas de diferentes espécies (...) soltou $D$. Willistoni (Eu acredito que por engano). Resumindo, toda a experiência foi por água abaixo. ${ }^{27}$

Na verdade, as inversões das populações que foram soltas já existiam na população natural. O que Dobzhansky pensou que seria uma nova inversão não era novidade. Os brasileiros tinham uma explicação diferente do que foi o engano. Pavan e Brito da Cunha pensaram que a suposição inicial estava errada porque a população continental não tinha sido estudada adequadamente. Dobzhansky pensou que ocorrera alguma contaminação na população simples e decidiu que um estudante misturou as populações. Os professores brasileiros defenderam o estudante, o que era o fim do envolvimento de Dobzhansky com a genética brasileira. ${ }^{28}$

O projeto, entretanto, continuou e produziu significantes resultados, alguns dos quais foram publicados com o nome de Dobzhansky. Então, seus desentendimentos não foram tão fortes quanto suas memórias mais tarde indicaram. O resultado de uma segunda experiência foi de fato interessante: não havia diferenças entre Raios $\mathrm{X}$ induzidos e ocorrências naturais de genes letais detectadas em condições heterizogóticas. "Este resultado foi inesperado, porque por muito tempo se acreditou que genes selvagens, estando sujeitos à seleção natural por muito tempo, seriam 
menos deletérios em condições heterozigóticas, que os letais induzidos recentemente ${ }^{.29}$ Este resultado parecia indicar que heteroziguismo per se tem um valor adaptativo.

\section{A Terceira Fase}

Até 1956 havia quase 12 centros de pesquisa genética no Brasil, muitos dos quais, incluindo o de Cavalcanti, no Rio de Janeiro, e o de Cordeiro, em Porto Alegre, fundado em 1949, começaram como centros de pesquisa em Drosophila. A terceira fase de Cavalcanti foi de pesquisas concebidas independentemente, sendo um projeto, dele mesmo, representativo sobre quantidade macho/fêmea em D. prosaltans; de Malogolowkin sobre os caracteres genitais nas sistemáticas de Drosophila; de Warwick Kerr e Sewall Wright sobre o efeito da mudança genética na estrutura de uma população Drosophila melanogaster; de Francisco Salzano com Hampton Carson sobre fatores causadores do isolamento sexual em populações naturais de Drosophila, sem falar em vários projetos que tinham Drosophila como tema.

Quando se considera o sucesso da genética no Brasil, deve-se levar em conta alguns fatores. Primeiro, como notou Dobzhansky no elogio a André Dreyfus, "Uma escola científica, quando se baseia numa importante e viável idéia, pode viver por longo tempo depois da morte de seu fundador". ${ }^{30} \mathrm{O}$ programa de pesquisa em si é a principal razão para o sucesso de uma disciplina. Além disso, a natureza das populações naturais de Drosophila, disponível no Brasil, dava grande vantagem aos pesquisadores locais. Melanogaster, lembrava Dobzhansky, pode ser estudada em qualquer lugar do mundo,

mas um biólogo no Brasil tem uma vantagem enorme em utilizá-las como material para seu trabalho de espécies brasileiras de Drosophila, ou animais das abundantes plantas tropicais dos fechados campos das florestas tropicais (...) As moscas do tipo Drosophila mostraram-se o material mais favorável para estudos de problemas de população genética e de evolução. ${ }^{31}$

O programa de pesquisa, que era de Dobzhansky, combinado com o maravilhoso estoque local de Drosophila, criou o que Robert Merton chama um 'lugar estratégico de pesquisa', caracterizado por um programa que 
está constantemente se desenvolvendo e produzindo grande quantidade de novos resultados, neste caso ainda, com acesso direto aos laboratórios americanos e publicações em geral.

O segundo notável aspecto do sucesso dos brasileiros foi o estilo adotado pela pesquisa, que foi coordenado e em cooperação. Muito cedo, de acordo com Pavan (1989), foi deliberadamente tomada a decisão de limitar o número de projetos. A organização cooperativa de pesquisa, além disso, tornou possível formular continuamente generalizações que trouxeram novos e nunca vistos problemas de pesquisa. Em palestra de 1952, Dobzhansky registrou que qualquer um podia publicar um artigo científico. O mais difícil era "desenvolver um coerente programa de pesquisa, que busque um importante objetivo, cujos resultados não preencham meramente páginas de revistas, mas resolvam ou revelem fenômenos até agora desconhecidos" (Cunha, 1989: 450). Esta coerência foi alcançada pela coordenação e cooperação entre os pesquisadores de um razoavelmente grande grupo central. Pavan observou estas vantagens em 1954:

Nós acreditamos que este tipo de trabalho traz resultados consideravelmente melhores do que os que podem ser obtidos de uma série de esforços independentes e descoordenados de vários trabalhos de investigações isolados. Afora a massa de dados obtidos, o trabalho resultou na formulação de algumas generalizações significativas para o interesse geral da biologia, embora tímida na época. Como freqüentemente acontece na pesquisa científica a solução de alguns problemas possibilita o surgimento de novos. Nós estamos ansiosos para explorar as possibilidades abertas pelos resultados obtidos até agora e para desenvolver mais trabalhos. ${ }^{32}$

A Fundação Rockefeller, na pessoa de Harry Miller, gostava desse estilo e o encorajava, porque ele tendia a criar novos núcleos de pesquisa liderados por pessoas treinadas no programa do centro. Ele tinha isto em mente até o momento da segunda visita de Dobzhansky, cujo propósito (Miller anotou para si) era duplo: 1) "capitalizar sobre a presença de Dobzhansky (ele está de acordo)"; e 2) "estimular trabalhos com Drosophila em outros lugares, num continente virgem". ${ }^{33}$

Em resumo, a pesquisa de Drosophila se tornou um caminho nobre de sucesso da genética brasileira. Até alguns jovens pesquisadores que odiavam o tema trabalharam sobre ele da mesma forma. A saída de Newton Freire-Maia da linha oficial da pesquisa sobre Drosophila foi marcada por seus problemas com Dobzhansky em 1948: "Quanto mais ele havia estudado espécies que não apresentavam inversões 
cromossômicas, seguia-se uma guerra com o big boss (Dobzhansky), que em geral criticava os estudos com espécies 'domesticadas ou semidomesticadas'" (Cordeiro, 1989: 445). ${ }^{34}$

Naturalmente, o patrocínio da Fundação Rockefeller para o empreendimento não foi um fator insignificante para o seu sucesso: primeiro enviando Dobzhansky; depois, apoiando qualquer membro do grupo de 1948 que se dispusesse a ficar um ano no laboratório de Dobzhansky ou com algum outro geneticista: os geneticistas humanos gravitavam em torno de James Neel, em Michigan, e contavam com a grande flexibilidade de Miller em ouvir o que os brasileiros tinham a dizer. Os geneticistas brasileiros viram mais tarde o modus operandi distinto de Miller como uma grande contribuição para o sucesso da disciplina. Os pedidos iniciais eram feitos sempre oralmente: ele visitava o laboratório, para então ter uma discussão geral com o staff sobre quais eram os materiais necessários. Algumas semanas depois de providenciar o auxílio e somente depois, pedia para apresentar uma lista específica do pedido, geralmente equipamento e reagentes (Cordeiro, 1989: 446). O papel de Miller na alocação de bolsistas para estudar fora foi também significante. Como Brito da Cunha (1990: 11) descreveu mais tarde:

Esta judiciosa política tem como seu melhor exemplo a Fundação Rockefeller e especialmente seu diretor, Dr. Harry M. Miller Jr., a quem é devido seu sucesso e a grata sabedoria com que ele atuou. Miller visitava nossos laboratórios uma ou duas vezes ao ano. Ele falava com todos os pesquisadores do laboratório para ver como ia a pesquisa. Ele aconselhavase com o pessoal do laboratório e entrevistava cada candidato. Ele somente dava bolsa aos pesquisadores já aprovados para o doutorado e que tinha uma prova da garantia do emprego ao retornar ao país. Também mantinha contato cerrado com o bolsista no exterior, tanto quanto com seu professor. Ao retornar ao Brasil, o bolsista recebia fundos para aquisição de equipamento necessário para proceder seu trabalho. Desta maneira ele levou para fora somente um pessoal muito selecto e que já adquirira o que era possível aqui no Brasil. ${ }^{35}$

A Fundação Rockefeller, além disso, tinha um conjunto específico de valores e, em geral, indefinidos, um modus operandi que era fazer os picos mais altos' para identificar os talentos científicos já imbuídos do sistema de valores da ciência ou representando uma boa chance para ser inculcado com este. Dreyfus observou em 1948, quando procurava possíveis membros para um time de estudantes: a Rockefeller Foundation, escreveu, "não está 
interessada em diletantes", não importa quão brilhantes sejam. Somente aqueles que prometem continuar o trabalho começado com Dobzhansky seriam considerados. ${ }^{36}$ Dobzhansky, naturalmente, promovia e professava os mesmos valores.

Finalmente, eu considero que havia uma relação entre a grande onda da eugenia no Brasil neste período e o clima que afetou a recepção da genética mendeliana. Tal conexão poderia explicar parcialmente a predisposição dos futuros 'Drosophilistas' para a genética como um campo interessante e socialmente relevante, ${ }^{37}$ e também iluminaria o clima dominante da opinião acadêmica e da burocracia governamental que apoiaria e até exigiria a criação de centros de pesquisa especializados neste campo.

\section{Notas}

1 Artigo publicado inicialmente em Cueto (1994). A pesquisa para este artigo foi possivel graças ao auxilio da National Science Foundation. Uma versão anterior deste artigo, intitulada "Estabelecendo disciplinas científicas na América Latina: genética no Brasil, 1943-1960", foi apresentada no encontro "Ciência e Descobrimento" em Madri, junho de 1991.

2 Sobre Teixeira Mendes, ver Piza Jr. (1963).

3 Ver o artigo de Domingues (1929, 1930).

4 Teoria que Piza Jr. estabeleceu em seu livro Localização dos Fatores na Linina Nuclear como Base de uma Nova Teoria sobre a Hereditariedade (1930).

5 Por causa de seus esforços, os geneticistas brasileiros soletravam 'cromossoma' em vez de 'cromozoma'; 'gametocito' no lugar de 'gametócito' etc. (Piza Jr. 1961).

6 Ver Dreyfus (1929).

7 Brieger naturalmente tinha lido o influente livro de Dobzhansky (1941); ele o cita assim como a Fisher (1930) na sua bibliografia.

8 "Grants from the Foundation: a fundamental study of evolution", 1 jun. 1956. Rockefeller Foundation Archives (neste momento RFA), R.G. 1.2, Série 305, Caixa 45 , Documento 392, Rockefeller Archive Center (neste momento RAC).

- Memos, 18 e 23 nov. 1942; Miller para William Vogt, 24 nov. 1942, RFA, R.G. 1.1, Série 200, Caixa 132, Folder 1631, RAC.

v Dobzhansky para Miller: 24 nov, 1942. RFA, R.G.1.1 Série 200, Caixa 132, folder 1631, RAC.

" Os documentos sobre este episódio são muito poucos. Ver Dobzhansky para Wright, 26 jan. 1943; Sewall Wright Papers, (neste momento Wright Papers), American Philosophical Society (neste momento APS), e Provine, Sewall Wright, 386-388.

2 Ver nota 8.

1 Entrevista de Antonio Brito da Cunha a Thomas Glick. São Paulo, 22 mar. 1990. 
Dobzhansky, Oral History Memoir, 54814 nov. 1962.

5 Cavalcanti, "Centro de Pesquisa de Genética da Faculdade Nacional de Filosofia da Universidade do Brasil", Atas, 53-58.

16 Dobzhansky, Oral History Memoir, 559.

v Dobzhansky, Oral History Memoir, 556.

18 De acordo com Brito da Cunha, em entrevista a Thomas Glick, estes oito eram os participantes-chave. Dobzhansky, além disso, usualmente incluia sua esposa, Natasha, e Nascimento Pereira. Pavan listou treze membros originais numa carta de 1953 e no ano seguinte colocou o número de onze; ver Pavan para Rubens Maciel: 24 fev. 1953; Pavan para Miller: 4 jun. 1954; e "Research Project of Study of Population Genetics and Ecology of Tropical Organisms", RFA, R.G. 1.2 Séries 305, Caixa 45, Folder 390, RAC. Outros como Dreyfus, Frota-Pessoa e Freire-Maia foram claramente envolvidos.

* Esta descrição dos resultados de 1948-1949 é de Brito da Cunha em entrevista a Thomas Glick.

o Burla para Miller: 1 dez. 1949, RFA, R.G. 1.2, Séries 305, Caixa 45, Folder 390, RAC.

21 Dobzhansky, Genetic Structure, 207, se refere à pesquisa finalmente publicada como Dobzhansky \& Cunha (1955).

2 Dobzhansky para Wright: 28 set. 1948. Wright Papers, APS.

23 Este artigo é um documento fundador da ecologia tropical.

24 Wright (1968-78, 4 v.) cita Pavan et al. (1951) no v.l., p.25; Burla et al. (1950) no v.4, p.124-125; e Dobzhansky, Burla \& Cunha (1950) no v. 4, p. 125-126.

z Dobzhansky, Oral History Memoir, 576.

* Glass, no livro The Roving Naturalist (1980: 165). Havia outro fator surpreendente em Angra dos Reis, lugar apreciável para um particular tipo de experimento. Miller anotou no seu diário com atenção para o pedido de Pavan de cobalto-60 para tratar as populações do laboratório destinadas ao projeto: "Dobzhansky sente que este é provavelmente o único lugar do mundo onde tais estudos podem ser feitos sob tais condições tão favoráveis. Os resultados são esperados para esclarecer o que acontecia em população humana numa cidade de tamanho médio atingida pela bomba atômica". Dobzhansky, Oral History Memoir, 576.

25 Francisco M. Salzano, entrevista a Thomas Glick. Porto Alegre, 30 mar. 1990.

* Relatório de Brito da Cunha e Crodowaldo Pavan (anexo 1), RFA, R.G.,1.2. Série 305, Caixa 45, Doc. 396, RAC.

D Citado por Pavan em Atas, 63.

3) Pavan em Atas, 64.

I "Research Project of Study of Population Genetics and Ecology of Tropical Organism", 2, RFA, R.G.1.2, Série 305, Caixa 45, Doc. 390, RAC.

3 Miller Diary, 23 apr. 1956, RFA, R.G. 1.2, Série 305, Caixa 45, Documento 392, RAC. Pavan, na proposta enviada a Miller em 30 de dezembro de 1957, deixou claro que a Comissão de Energia Atômica estava interessada nos efeitos da radiação nas populações de ratos e Drosophila para ver o que aconteceria com a população humana. A perspectiva nuclear não teve, entretanto, papel significativo na pesquisa. RFA, R.G. 1.2, Serie 305 , Caixa 45, Folder 396, RAC. 
34 Cordeiro (1989). Salzano confirmou este fato: "Freire não gostava de Drosophila. Ele perguntava por que não trabalhar com moscas domésticas (melanogaster) e Dobzhansky ficava bravo. Newton dizia que inversões não eram adaptativas". De acordo com Salzano, Kerr era outro que não gostava de Drosophila (Salzano em entrevista a Thomas Glick). Em 1951, Freire fundou o laboratório de Genética Humana na Universidade do Paraná, Curitiba, onde, apesar de tudo, escreveu uma importante série de artigos sobre polimorfismo cromossômico, tópico favorito de Dobzhansky, em oito populações naturais de Drosophila. Ver Freire-Maia, N. Laboratório de Genética Humana da Universidade do Paraná, Atas, 213-217.

3 Para outras retomadas de Miller, ver Cunha (1965); Cordeiro (1989); Rio de Janeiro (1984).

36 Dreyfus para Edgar Santos: 16 fev. 1948, RFA, R.G. 1.2, Série 305, Caixa 45, Doc. 389, RAC.

* Mas como observado por Nancy Stepan, a vaga eugênica podia também ter funcionado de outro modo, encorajando o mendelismo como uma forma de fugir da pseudoconsciência envolta na eugenia.

\section{Referências Bibliográficas}

BRIEGER, F. G. Considerações sobre o mecanismo da evolução. Anais da Escola Superior de Agricultura Luiz de Queiroz, 1: 177-203, 1944.

BURLA, H. et al. Population density and dispersal rates in Brazilian Drosophila Willistoni. Evolution, 31: 352-404, 1950.

CORDEIRO, A. R. Genética no Brasil: passado e futuro. Ciência e Cultura, 41: 445-446, 1989.

CUETO, M. Missionaries of Science: the Rockefeller Foundation and Latin America. Indianapolis: Indiana University Press, 1994.

CUNHA, A. B. da. Homenagem ao Dr. Harry M. Miller Jr. Boletim da Sociedade Brasileira de Genética, 7:2-3, 1965.

CUNHA, A. B. da. O poder da genética clássica. Ciência e Cultura, 41: 450, 1989.

CUNHA, A. B. da. Perspectivas Atuais e Futuras das Ciências Biologicas no Brasil. Brasília: CNPq, 1990.

CUNHA, A. B. da. \& DOBZHANSKY, T. A further study of chromosomal polymorphism in Drosophila wllistoni, and its relation to the environment. Evolution, 8: 119-134, 1954.

CUNHA, A. B. da.; BURLA, H. \& DOBZHANSKY, T. Adaptative chromosomal polymorphism in Drosophila Willistoni. Evolution, 4: 212-235, 1950.

DOBZHANSKY, T. Genetic structure of natural populations. Carnegie Institute of Washington Yearbook, 48: 201-212, 1948-49.

DOBZHANSKY, T. Genetics and the Origin of Species. Nova Iorque: Columbia University Press, 1941.

DOBZHANSKY, T. Evolution in the tropics. American Scientist, 38: 209-221, 1950.

DOBZHANSKY, T. What is an adaptative trait? American Naturalist, 90: 347, 1956.

DOBZHANSKY, T. \& PAVAN, C. Studies on Brazilian Species of Drosophila. Boletim da Faculdade de Filosofia Ciências e Letras da Universidade de São Paulo, Biologia Geral, 4: 7-72, 1943. 
DOBZHANSKY, T. \& CUNHA, A. B. da. Differentiation of nutritional preferences in Brazilian species of Drosophila. Ecology, 36: 34-39, 1955.

DOBZHANSKY, T.; BURLA, H. \& CUNHA, A. B. A comparative study of chromosomal polymorphism in sibling species of the willistoni group of Drosophila. American Naturalist, 84: 229-244, 1950.

DOMINGUES, O. As teorias de hereditariedade. Revista de Agricultura de Piracicaba, 4: 95$103,1929$.

DOMINGUES, O. Teoria de fatores mendelianos. Revista de Agricultura de Piracicaba, 5: 3$18,1930$.

DREYFUS, A. O estado atual do problema de hereditariedade. In: PRIMEIRO CONGRESSO BRASILEIRO DE EUGENIA, 1, 1929, Rio de Janeiro. Atas e Trabalhos, p. 87-97.

FISHER, R. A. The Genetical Theory of Natural Selection. Oxford: Oxford University Press, 1930.

GLASS, B. (Ed.) The Roving Naturalist: travel letters of Theodosius Dobzhansky Philadelphia: American Philosophical Society, 1980-81.

KRUG, C. A. Genética e evolução. Revista de Agricultura de Piracicaba, 15: 271-288, 1940.

PAVAN, C. Algumas questões sobre o desenvolvimento da ciência no Brasil e as lições na área da genética. Ciência e Cultura, 41: 454, 1989.

PAVAN, C. \& CUNHA. A. B. da. Espécies Brasileiras de Drosophila. Boletim da Faculdade de Filosofia Ciências e Letras da Universidade de São Paulo, Biologia Geral, 7: 20-64, 1947.

PAVAN, C. et al. Concealed genic variability in brazilian populations of Drosophila Willistoni. Genetics, 36:13-30, 1951.

PIZA JR., S. de T. Localizafão dos fatores na Linina Nuclear como Base de uma Nova Teoria sobre a Hereditariedade. Piracicaba: Escola Agrícola Luiz de Queiroz, 1930.

PIZA JR. S. de T. Cadeira de zoologia da escola superior de agricultura 'Luiz de Queiroz' da Universidade de São Paulo. In: PRIMEIRO SIMPÓSIO SUL-AMERICANO DE GENÉTICA, 1, 1961, São Paulo.

PIZA JR., S. de T. Carlos Teixeira Mendes, o primeiro professor de genética no Brasil. Revista de Agricultura de Piracicaba, 38: 47-52, 1963.

PROVINE, W. B. Origins of the genetics of natural population series. In: LEWONTIN, R.C. et al.(Eds.) Dobzhansky's Genetics of Natural Populations I-XLIII. Nova Iorque: Columbia University Press, 1981.

PROVINE, W. B. Sewall Wright and Evolutionary Biology. Chicago: The University of Chicago Press, 1986.

RIO DE JANEIRO. História da Ciência no Brasil: Acervo de Depoimentos, 1984.

TEIXEIRA MENDES, C. T. A seleção empírica. Revista de Agricultura de Piracicaba, 3:(11-12): 1-20, 1928.

TEIXEIRA MENDES, C. T. A teoria da evolução e a agricultura. Revista de Agricultura de Piracicaba, 6: 263-273, 1931.

WRIGHT, S. Evolution and the Genetics of Populations. Chicago: University of Chicago Press, 1968-78. 4v. 


\section{O Espetáculo da Míscigenação ${ }^{1}$}

\section{Lilia Moritz Schwarcz}

Em finais do século XIX, o Brasil era recorrentemente descrito como uma imensa nação mestiça, representando, nesse sentido, um caso extremo e singular. "J'ai remarqué un fait singulier (...)"2 - dizia o naturalista Gustave Aimard, viajante francês que esteve no Brasil em 1887 - “(...) que je n'ai observé qu'au Brésil: c'est le changement que s'est operé dans la population par les croisement des races, ils sont les fils du sol"3 (1888: 225).

Mestiça era também a imagem que Louis Agassiz (1868: 71) formava do Brasil; esse país que se tornara uma espécie de paraíso dos naturalistas. Dizia, o reconhecido pesquisador suíço,

que qualquer um que duvide dos males da mistura de raças, e inclua por mal-entendida filantropia, a botar abaixo todas as barreiras que as separam, venha ao Brasil. Não poderá negar a deterioração decorrente do amálgama das raças mais geral ocorrido aqui mais do que em qualquer outro país do mundo, e que vai apagando rapidamente as melhores qualidades do branco, do negro e do índio deixando um tipo indefinido, híbrido, deficiente em energia física e mental.

O Conde Arthur de Gobineau, que permaneceu no Brasil durante 15 meses em missão oficial, também dedicou palavras duras quando tratou de descrever a situação racial que observara: "Trata-se de uma população totalmente mulata, viciada no sangue e no espírito e assustadoramente feia" (Raeders, 1988: 96).

Essa visão mestiça da nação não se limitava, porém, ao olhar que vinha de fora, aos inúmeros naturalistas que aqui estiveram. Internamente, o tema se reproduzia a partir de diferentes locais. Nos censos, nos jornais, nas pinturas, na visão de políticos e cientistas, raça aparecia como um 
argumento partilhado, uma interpretação interna bastante consensual. "Formamos um país mestiço (...) somos mestiços, se não no sangue, ao menos na alma", definia o crítico literário Sylvio Romero, da Escola de Recife, ao comentar "a composição étnica e antropológica singular" da população brasileira" (1968: 296).

João Batista de Lacerda, então diretor do Museu Nacional do Rio de Janeiro, na condição de representante de 'um thipico paiz miscigenado', era convidado a participar do I Congresso Internacional das Raças, realizado em julho de 1911, apresentando uma tese cujo título já era em si revelador: Sur les métis au Brésil. Neste ensaio, o país não era apenas caracterizado como mestiço, também se exaltava a mudança operante no local: "(...) o Brasil mestiço de hoje tem no branqueamento em um século sua perspectiva, saída e solução" (1911: 25).

Partindo dos recintos médicos baianos, era também com esse sentido que, em 1894, Nina Rodrigues ponderava: "se um país não é velho para se venerar ou rico para se fazer representar, precisa ao menos tornar-se interessante" (1959: 11). Revelando uma posição bastante lúcida, o conhecido médico aglutinava percepções da época. Com efeito, o que resumia a singularidade local não era mais a flora, a fauna ou a pujança da terra, mas sim uma composição racial singular, um certo 'espetáculo da miscigenação'.

\section{O Medo da Degeneração}

Saudada pelos cientistas estrangeiros como fenômeno desconhecido e recente, a miscigenação transformava-se em tema polêmico entre as elites locais. De um lado, o problema racial é a linguagem pela qual se torna possível apreender as particularidades observadas. Como bem mostrou Hobsbawm (1987), nesse contexto em que discursos raciais vinculavamse a projetos de cunho nacionalista, soava correto imaginar uma nação em termos biológicos ou estimar uma futura homogeneidade, como previa Lacerda. No entanto, a constatação de que esta era uma 'nação mestiça' gerava novos dilemas para os cientistas brasileiros. Se falar na 'raça' parecia oportuno - já que a questão referendava-se empiricamente e permitia certa naturalização de diferenças, sobretudo sociais - o mesmo tema gerava paradoxos: implicava admitir a inexistência de futuro para uma nação de raças mistas como a nossa. Isto é, o conjunto dos modelos 
evolucionistas não só elogiava o progresso e a civilização como concluía que a mistura de raças heterogêneas era sempre um erro, e levava à degeneração não só do indivíduo como de toda a coletividade.

Evidenciava-se a defasagem entre as teorias deterministas que chegavam de fora quando pensadas em função da 'realidade mestiça de dentro' e a rigidez da teoria quando o objeto em questão era a nação brasileira. A saída foi então preconizar a adoção do ideário científico; porém, sem seu corolário teórico - aceitar a idéia da diferença ontológica entre as raças sem a condenação à hibridação -, à medida que o país, a essas alturas, encontrava-se irremediavelmente miscigenado.

Incômoda era a situação desses intelectuais que oscilavam entre a adoção de modelos deterministas e a verificação de que o país, pensado nesses termos, era inviável. "Devia ser difícil abrir mão da crítica externa e de uma certa internalização desse tipo de visão estrangeira a respeito do Brasil como país aberrante", afirma Roberto Ventura (1991: 91). Afinal, em um momento em que se redescobria a mesma nação, era como obstáculos à civilização e barreiras à identidade nacional que os grupos indígenas, americanos e mestiços eram incorporados (Queiroz, 1989: 32).

\section{Entre 'Homens de Sciencia'}

É interessante, tendo em mente essa 'representação mestiça' do país, entender a relevância e a originalidade desse tipo de teoria que, no Brasil, conheeeu seu momento de maior influência no período que vai de 1870 a 1930. Modelo de sucesso na Europa de meados dos oitocentos, as teorias raciais chegam tardiamente ao Brasil, recebendo, porém, uma entusiástica acolhida, em especial nos diversos estabelecimentos de ensino e pesquisa, que, na época, congregavam boa parte da reduzida elite pensante nacional.

O momento selecionado é particularmente significativo não só por aglutinar uma série de episódios relevantes - o final da Guerra do Paraguai, a fundação do partido republicano, a promulgação da lei do Ventre Livre -, como também por anunciar a entrada de novos modelos científicos deterministas e o amadurecimento de alguns centros de ensino e pesquisa nacionais, como os institutos históricos, os museus etnográficos, as faculdades de direito e de medicina. 
Nesses locais, o tema racial esteve particularmente presente, mas não de forma unívoca. 'Raça' aparece como um conceito de negociação, sendo que as interpretações variaram assim como eram diversas as metas e especificidades de cada um desses estabelecimentos.

As personagens que integraram essas instituições são esses - hoje 'obscuros homens de sciencia' que, em finais do século XIX e do interior dos locais em que trabalhavam, tomaram para si a quixotesca tarefa de abrigar uma ciência positiva e determinista e, utilizando-se dela, procuraram liderar e dar saídas para o destino desta nação. Misto de cientistas e políticos, pesquisadores e literatos, esses intelectuais se moveram nos incômodos limites que os modelos lhes deixaram, haja vista que, naquele momento, indagar sobre que nação era essa significava, de alguma maneira, se perguntar sobre que raça era a nossa ou, então, se uma mestiçagem tão extremada não seria um sinal em si de decadência e enfraquecimento.

Museu de Frenologia

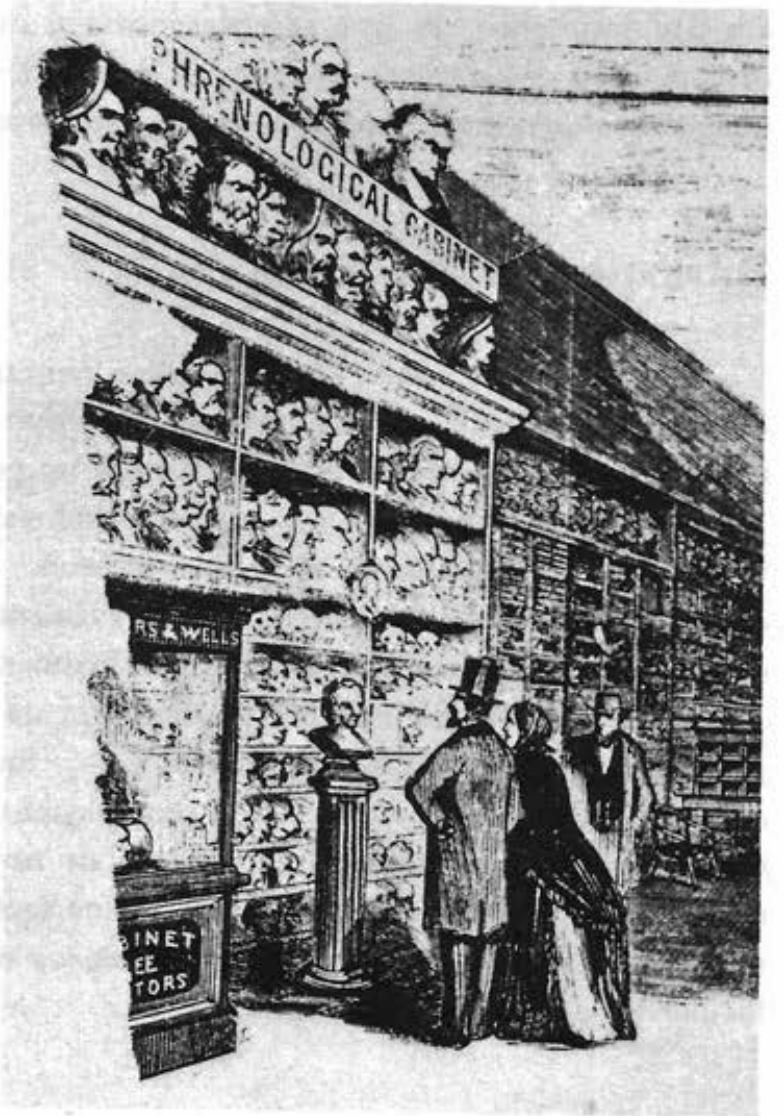




\section{Raça: um conceito negociado}

O fin-de-siècle brasileiro era vivenciado nesses meios, dessa maneira, com grande dose de pessimismo. Com efeito, os cientistas, ao mesmo tempo em que se encontravam desiludidos com as promessas de igualdade, indagavam-se sobre as causas persistentes das diferenças entre os homens.

Nos museus etnográficos de Belém, São Paulo e Rio de Janeiro, por exemplo, a ampla utilização de argumentos evolucionistas permitiu explicar cientificamente as diferenças, classificar as espécies, localizar os pontos de atraso. Partindo dos modelos das ciências naturais, esses pesquisadores buscavam uma ponte entre as espécies botânicas, zoológicas e a humanidade que pudesse prever, como pretendia Herman von Ihering, então diretor do Museu Paulista, um desenvolvimento comum: "a degenerescência presente nos tipos híbridos na zoologia pode ser com certa facilidade percebida nos grupos humanos (...) Longe dos tipos puros é com cuidado que deve ser analisada a miscigenação local" (Revista do Museu Paulista, 1987: 68).

Adeptos, em sua maior parte, dos modelos poligenistas de análise que entendiam as raças como fenômenos essenciais e ontológicos resultantes de centros de criação diversos - esses teóricos dos museus concluíram não só que "(...) a evolução encontrada na natureza era exatamente igual àquela esperada para os homens (...)", mas supunham que "(...) os grupos inferiores constituíam barreiras frente ao progresso da civilização" (Boletim do Museu Paraense, 1894: 16).

É ilustrativa, nesse sentido, a defesa que faz von Ihering, em 1911, no jornal $O$ Estado de São Paulo, do extermínio dos Kaingang, em nome da construção da estrada de ferro Noroeste do Brasil. Utilizando-se de modelos evolucionistas e deterministas, o naturalista alemão condenava "grupos indígenas inferiores" que, em sua ótica, desapareceriam pela "mera ação da natureza". Diante dos prognósticos científicos, nada havia a obstar; "nem mesmo uma moral de fundo humanista". ${ }^{4}$

Cumpriam os museus etnográficos no país, portanto, um papel específico. Ao mesmo tempo que ajudaram a popularizar no exterior a imagem de que o Brasil seria um grande laboratório racial, introduziram um olhar particular. O olhar do naturalista que classifica conjuntamente a flora, a fauna e o homem em suas produções. "A perfectibilidade humana fará seu papel no Brasil, assim como a natureza não cessa de agir nas espécies vegetais e animais" (1894: 73), dizia Goeldi no Boletim do Museu Parense, acreditando em um processo evolutivo para a desacreditada população nacional. 
Nos institutos históricos, por sua vez - e em especial nos estabelecimentos carioca, paulista e pernambucano - a entrada tardia dos modelos deterministas levou à utilização de explicações variadas: uma visão otimista, católica e patriótica paralela a uma concepção determinista e evolutiva da nação. O resultado foi um modelo que acomodou explicações de teor monogenista, que concebia a humanidade como una em sua origem e desenvolvimento, mas que não se furtou a recorrer a argumentos darwinistas sociais quando se tratava de justificar hierarquias sociais consolidadas:

\begin{abstract}
Abrem-se-me então os olhos e percebo que taes homens já nu o vivem na inocência paradisíaca e que as teorias de Jean Jacques Rousseau são meros sonhos. (...) Os americanos não representam uma raça selvagem, representam antes uma raça degenerada que se tornou selvagem. (...) Assim poucos séculos se passarão e o último americano deitar-se-á. Se não se garantir a superioridade do sangue branco toda a população do continente definhará. (Revista do Instituto Histórico de São Paulo, 1904: 53-54)
\end{abstract}

Nem bem descobridores, nem bem missionários, esses cientistas ora encontravam uma nação a admirar, ora se debruçavam com temor sobre seu país, propondo - no lápis e papel - reformas e saídas que, em última instância, dependiam de sua própria atuação. Nesse sentido, talvez o debate tenha mesmo se concentrado entre as escolas de direito e medicina. Instaurada uma disputa pela hegemonia e pelo predomínio científico no país, percebem-se dois contendores destacados. De um lado, o remédio; de outro, a lei; o veneno previsto para uns, o antídoto nas mãos dos outros.

Para os 'homens de direito', a responsabilidade de conduzir a nação estava vinculada à elaboração de um código unificado que tornasse homogêneas as grandes diferenças observáveis.

O Estado é necessário (...) É uma formação necessária (...) e que resulta de uma evolução social, que vinculada aos homens de lei imprime uma única direção à sociedade (...) Por fim é a força o elemento gerador do Estado, ela se manifesta acima da luta das raças ou de grupos entre nós tão heterogêneos. (Revista Acadêmica da Faculdade de Direito de Recife, 1922: 103)

No entanto, no caso das escolas de Direito, se existiam concepções partilhadas, a amarra institucional não chegou a encobrir diferenças teóricas fundamentais: o argumento racial construído em Recife contrastou com a interpretação liberal da academia paulista. De fato, partiam de Recife as leituras germânicas sobre as determinações das raças e a defesa - que consagrou a figura de Sylvio Romero - de uma mestiçagem 'moral' e 
'física' como recurso de unidade nacional. Já a escola paulista analisava com cautela a introdução dos modelos darwinistas sociais, com "a crítica de quem reconhece a verdade de alguns conceitos e repele os exageros desses juris consultos (...)" (Revista Acadêmica da Faculdade de Direito de São Paulo, 1906: 67).

As duas escolas, contudo, revelaram possuir projetos bastante coincidentes e harmônicos ora quando se tratava de defender a hegemonia da prática do Direito, ora quando se buscava garantir uma certa hierarquia social. Nesse caso, o argumento escorregava da cultura para a natureza, do indivíduo para o grupo, da cidadania para a raça.

Revelador é o debate sobre a entrada de imigrantes asiáticos e africanos, tônica central de várias sessões na Câmara de Deputados e de outras instâncias atuantes durante os anos 90 do século XIX. Com efeito, partiu de São Paulo a política mais restritiva e que propôs graves entraves à introdução de mão-de-obra negra e oriental. Nesse caso, São Paulo demonstrou na prática o quanto era permeável às conclusões teóricas racistas e darwinistas sociais, tão populares em Recife. Sempre em nome de um projeto eugênico de depuração das raças, a bancada paulista, "composta pelos digníssimos bacharéis da escola paulista de Direito" limitou a admissão a apenas alguns países, criticando duramente o que chamava sem "as características amorais dos africanos e dos chins", entendidos como "inassimiláveis, portadores de línguas e costumes estranhos aos nossos, praticantes do suicídio e do ópio" (Nogueira, 1984; Hall, 1976; Monteiro, 1992).

Dessa maneira, enquanto na Escola de Recife um modelo claramente determinista dominava; em São Paulo, um liberalismo de fachada - cartão de visitas para questões de cunho oficial - convivia com um discurso racial prontamente acionado quando se tratava de defender hierarquias e explicar desigualdades sociais.

A teoria racial, quando utilizada, cumpria o papel de deixar claro como para esses juristas falar em democracia não significava discorrer sobre a noção de cidadania. Assim, se em Recife o indivíduo foi sempre entendido como uma amostra de seu grupo, em São Paulo, com a adoção de um liberalismo de cunho conservador e cada vez mais antidemocrático, a questão da cidadania como que desaparecia e com ela a vontade do indivíduo. Como diria um artigo publicado em 1914 na revista da escola paulista, "o indivíduo no Brasil sempre foi letra morta (...) e afinal, quem 
se importa" (Revista Acadêmica da Faculdade de Direito de Recife, 1914: 44).

Por fim, restaria discorrer sobre o universo das faculdades de medicina, onde a figura do médico e do cientista social se confundem, dando lugar à imagem do higienista e do perito criminal, ambos intelectuais de intervenção política e social. Esse contexto é marcado pela ascensão de uma nova personagem - o 'médico político' - que se afirma pela procura de espaços mais abrangentes de atuação:

Não senhores! Se é belo de contemplar-se o espetáculo singelo da caridade encarnada no médico que allivia padecimentos individuaes, não é menos o daquele que compenetrado do papel social da medicina política entorna para todos os lados seus benefícios alargando incomensuravelmente o círculo de suas atividades profissionais, que na escala da perfectabilidade dos sentimentos auxilia a sociedade em sua passagem do egoísmo ao altruísmo. O médico moderno digno de seu nome e condição deve praticá-la plenamente no exercício da medicina política. (Americano, 1896: 398)

Trata-se, portanto, da emergência de um saber médico no país, pautado por novas ambições e projetos, que fazem desses profissionais concorrentes à altura na disputa pela hegemonia intelectual no país. Os alvos, porém, são específicos: enquanto no interior da Faculdade de Medicina da Bahia percebe-se uma atenção especial aos temas da medicina criminal e toda uma batalha personificada por Nina Rodrigues nesse sentido, no Rio de Janeiro já será a pesquisa e a atuação na área da higiene pública e da epidemiologia que congregarão o grosso dos esforços.

Os médicos da faculdade carioca, em primeiro lugar, buscavam sua originalidade e identidade na descoberta de doenças tropicais, como a febre amarela e o mal de Chagas, que deveriam ser prontamente sanadas pelos programas higiênicos, prova maior de avanço e contribuição. Diante dos números alarmantes, reveladores de que, no Brasil, morria-se, acima de tudo, por causa de moléstias contagiosas, ${ }^{5}$ partiam esses profissionais para uma ampla política de intervenção pública, tornando-se cada vez mais abrangente sua atuação.

Triste a nossa posição enquanto não se resolver entre nós o magno problema das doenças contagiosas e da vacinação obrigatória. Esta cada vez mais se impõe diante dos progressos realizados entre nós em relação à saúde pública, não podendo a nosso ver servir de excusa à sua execução a LIBERDADE INDIVIDUAL que seguindo a tendência moderna daqueles que mais a defendem deixa de existir diante do interesse geral da comunidade. (Boletim Médico, 1910: 107) 
Partindo de uma concepção alargada de doença - da qual fariam parte não só os 'doentes físicos', como 'mentais' e 'morais' - insistiam os médicos higienistas em uma primazia de sua atividade perante a vontade do indivíduo e em nome dos desígnios da coletividade. O profissional médico separava-se, dessa maneira, da ingerência de outros políticos e especialistas, exigindo independência em sua atividade e autonomia no seu diagnóstico. É esse o tom do discurso de Oswaldo Cruz quando em 1904, antes da famosa Revolta da Vacina, declarava ao Jornal do Comércio (1904: 9): "Preciso de recursos e da mais completa independência de ação. O governo me dará tudo que necessito, deixando-me livre na escolha de meus auxiliares, sem nenhuma interferência política". A ditadura sanitária era a única resposta que esses médicos conheciam diante da realidade desse país, descrito por Miguel Pereira, "como um grande hospital" (Brasil Médico, 1910: 93).

Os médicos baianos, por sua vez, procurarão pela mesma originalidade nacional, só que a encontrarão no cruzamento racial, que parecia representar, paradoxalmente, não só o nosso maior mal, como também a nossa suprema diferença. Com efeito, a referência ao tema da miscigenação ou 'do problema negro', como era normalmente caracterizado, era uma constante nesse local. Entendido como o grande fator que explicaria "nossa inferioridade como povo" (Gazeta Médica da Bahia, 1933: 7) ou 'nossa riqueza biológica', o cruzamento racial parecia significar uma questão fundamental.

É somente a partir desse contexto de debate que se pode entender a introdução da questão da medicina legal nesses recintos. Na condição de médicos peritos, especializados no estudo da mente do criminoso, defenderão a criação de uma prática diversa e especial. Afinal, estava em jogo a supremacia e autonomia no reconhecimento do crime e na qualificação do criminoso: "Para um povo de população heterogênea como o brasileiro, a identificação craniológica das raças adquire em medicina legal uma importância máxima", dizia o artigo de Nina Rodrigues (Gazeta Médica da Bahia, 1902: 36).

Adotando os métodos da escola positiva italiana, cujo grande teórico era Cesare Lombroso, os médicos baianos estabeleciam correlações rígidas entre aspectos exteriores e interiores do corpo humano, considerando a miscigenação, por princípio, um retrocesso, um grande fator de degeneração. Dessa maneira, os exemplos de embriaguez, alienação, epilepsia, violência ou amoralidade passavam a ser utilizados como provas da correção dos modelos darwinistas sociais em sua condenação ao cruzamento, em seu alerta à imperfeição da hereditariedade mista. Sinistra originalidade 
encontrada pelos peritos baianos: o enfraquecimento da raça permitia não só a exaltação de uma especificidade da pesquisa nacional, como também uma identidade do grupo profissional.

Mas se existem singularidades que distinguem essas duas faculdades de medicina é possível dizer que as relações foram, sobretudo, marcadas pela camaradagem e por uma divisão de áreas quase consensualmente aceita. A Bahia vinha com a antropologia criminal, o Rio de Janeiro com as pesquisas sobre medicina tropical. Enquanto para os médicos cariocas tratava-se de combater 'doenças', para os profissionais baianos era o 'doente', a população, que estava em questão.

\section{Entre o Veneno e o Antídoto}

De fato, se existiu alguma disputa pela hegemonia intelectual, essa se evidenciou entre os profissionais de direito e os de medicina: ora o remédio, ora a lei; o veneno para uns, o antídoto na mão dos outros. Se para os 'homens de direito' a responsabilidade de conduzir a nação estava vinculada à elaboração de um código unificado, para os 'profissionais médicos' somente de suas mãos sairiam os diagnósticos e a cura dos grandes males que assolavam a nação. Enquanto os profissionais médicos pretendiam curar as doenças e nossas heterogeneidades, bacharéis acreditavam encontrar no direito uma prática acima das diferenças sociais e raciais observadas.

Pensado nesses termos, o argumento racial continuava oportuno quando obliteradas as suas conclusões mais radicais; justificava teoricamente desde a construção de projetos políticos conservadores até a existência de hierarquias rígidas, agora cientificamente explicadas. Dessa maneira, ao adotar o jargão evolucionista e racial, essas elites letradas acabavam assumindo uma espécie de consciência do atraso, elas encontravam respaldo para redimensionar uma discussão sobre a igualdade entre os homens e, por conseguinte, sobre critérios de cidadania.

$\mathrm{O}$ mesmo contexto que encontra em um projeto liberal a solução para a nova configuração política procura, nas teorias deterministas, subsídio para transformar diferenças sociais em barreiras biológicas fundamentais. Ante a liberdade prometida pela abolição e a igualdade oferecida pela nova constituição, parecia imperativo repensar a organização 
desse novo país. Como dizia um artigo de 21 de dezembro de 1920 do Correio Paulistano, "os homens não nascem iguais absolutamente, supõese uma igualdade presumida pela lei sem o que não haveria lei (...)".

Transformada em utopia pelos cientistas nacionais, a igualdade conseguida mediante as conquistas políticas era negada em nome da natureza e imediatamente transformada em uma ilusão (Corrêa, 1983). Era exatamente essa a tese de Nina Rodrigues quando em 1906, dessa maneira, pronunciava-se na Gazeta Médica da Bahia (1906: 256-257):

Não pode ser admissível em absoluto a igualdade de direitos sem que haja ao mesmo tempo, pelo menos, igualdade na evolução (...) No homem alguma cousa existe além do indivíduo (...) Fazer-se do indivíduo o princípio e o fim da sociedade, como sendo o espírito da democracia, é um exagero da democracia, é um exagero da demagogia (...) As ideas da Revolução Franceza até hoje não se puderam concilliar pois 'abherrant inter $\operatorname{se}^{\prime}(. .$.

No entanto, mais interessante do que nomear a batalha existente entre direito e medicina ou do que refletir sobre o impacto dessas idéias, é pensar sobre a originalidade de sua utilização. Falar da adoção das teorias raciais no Brasil implica refletir sobre um modelo que incorporou o que serviu e esqueceu o que não se ajustava. Ou melhor dizendo, procurou nessas teorias justificativas para expulsar a 'parte gangrenada' da população, sem deixar de garantir que o futuro seria branco e ocidental.

É o próprio modelo que se redefine em função da matriz que o origina, velhos nomes com novos significados, o que comprova como, no Brasil, raça era um conceito original e negociado. Não se trata, dessa maneira, de entender a adoção das teses raciais como mero reflexo, cópia desautorizada, mas antes indagar sobre seus novos significados contextuais. A idéia é nomear e resgatar o impacto dessas teorias, atentando para o contexto político em que elas se inserem, sem deixar de lado a dinâmica de reconstrução de conceitos e modelos.

\section{Quem Fala em Raça não Prevê o Cidadão}

Fazendo as vezes de uma ideologia da cultura nacional, as teorias raciais cumprirão no Brasil papéis distintos. Como discurso leigo, vão se contrapor à Igreja e à influência religiosa. Legitimarão, ainda, as falas dos grupos urbanos ascendentes, responsáveis pelos novos projetos políticos e que viam nessas idéias sinais de 'modernidade', índices de progresso. 
Mas, se a questão racial foi operante à medida que apontava para determinadas compressões da sociedade, impediu ou relativizou a realização de outros debates. Ao mesmo tempo em que uma visão determinista gerou o fortalecimento de uma interpretação racial para a formação da nação, em contraposição, levou a um esvaziamento do debate sobre a cidadania e sobre a participação do indivíduo. Entendendo o sujeito como o resultado de seu grupo 'racio-cultural', esse tipo de teoria tendeu a negar a vontade individual perante a coerção racial e o determinismo do grupo somático de origem (Arendt, 1973). Com efeito, tais doutrinas tinham como característica a oposição não apenas ao humanismo do século XVIII como também à 'filosofia do voluntarismo', desqualificando o princípio universal da igualdade, herdeiro da Revolução Francesa. Por outro lado, como sugere Louis Dumont (1966: 320), esses dois modelos não estariam tão distantes: o racismo, como fenômeno recente, "responde sob uma forma moderna a uma função antiga". Reintroduzido já em inícios do século XIX, na Europa, como princípio de hierarquização em sociedades desigualitárias, o dogma racial pode ser, de certa forma, entendido como um estranho fruto, uma perversão do Iluminismo humanitarista, que buscava naturalizar a desigualdade em sociedades só formalmente igualitárias.

Quando se trata de pensar no caso brasileiro, o que se nota é a emergência de dois debates contemporâneos: de um lado, o enraizamento de um modelo liberal jurídico na concepção do Estado; de outro, o paralelo enfraquecimento de uma discussão sobre a cidadania em função da retomada do debate sobre a questão da igualdade - tendo como base as conclusões deterministas raciais. Teorias formalmente excludentes, racismo e liberalismo conviveram, em finais do século, merecendo locais distintos de atuação.

É possível dizer que, no Brasil, se desenvolveram formas de sociabilidade diversas, nas quais a afirmação do Igualitarismo das Luzes e dos Direitos dos Homens pode existir de maneira difusa por causa da ausência da noção de direitos dos cidadãos. Em uma sociedade na qual a falta do indivíduo, das instituições e do formalismo do Estado - tão desfigurado em meio à dispersão dos poderes locais - era fato, as teorias raciais pareciam 'estar no lugar', na medida em que o problema da nacionalidade escapava do plano da cultura para se transformar em uma questão da natureza.

Fazendo uso dos instrumentos que possuíam, esses 'homens de sciencia' encontrarão uma convivência extravagante entre discurso liberal e racial. Se o primeiro constará do texto da lei, das falas oficiais; o segundo 
surgirá nos romances naturalistas, nas teses científicas. De um lado, os 'homens de medicina', que viam na mistura das raças o nosso maior veneno e se responsabilizavam pelo antídoto; de outro, os 'homens da lei', que apenas teoricamente se afastavam desse debate, pois apesar da defesa formal de um Estado liberal, na prática, havia o temor dos efeitos da Grande Guerra e da mestiçagem acelerada, e eles ponderavam “(...) sobre a justeza de se agir sobre o perfil de nossa população, composta por raças tão desiguais, e talvez pouco preparadas para o exercício da cidadania" (Revista Acadêmica da Faculdade de Direito de Recife, 1919: 36).

Além disso, se nessas esferas institucionais é muitas vezes como um discurso culpado e cientificamente legitimado que o argumento racial de análise social aparece referido, o mesmo não pode ser dito de outros meios nos quais esse modelo científico determinista pode ser assumido sem qualquer receio. Nos discursos do dia-a-dia, na representação popular, nos jornais de circulação diária, é quase corriqueiro o argumento que traduz a ciência em termos populares e encara a raça como uma questão de importância fundamental nos destinos da nação. "Simplificando o que tão bem se diz nas teorias científicas, é através da raça que se determina os destinos de um povo, da nação (...)" (Correio Paulistano, 1901: 84).

É mais uma vez essa confusa relação entre esferas pública e privada, tema de reflexão de vários ensaístas nacionais, ${ }^{6}$ que pode ser recuperada. São dois modelos que, nesse contexto, parecem cumprir um acordo tácito, uma divisão entre locais distintos de inserção: o universo oficial, o espaço familiar. Com efeito, se essa visão racial da nação partiu dos estabelecimentos científicos, esteve sobretudo presente no domínio das relações pessoais, das vivências cotidianas, das experiências mais intimistas. Dessa maneira, se vai longe o contexto intelectual de finais do século passado; se já não é mais cientificamente legítimo falar das diferenças raciais a partir dos modelos darwinistas sociais, a raça permanece, porém, como tema central no pensamento social brasileiro.

Por vezes, é a visão otimista freyriana (Freyre, 1930) que prevalece, transformando o país em uma grande imagem de convivência racial pacífica e idílica. É de novo a raça que aparece em expressões como 'esse é um sujeito de raça'; 'você vale quanto vale a sua raça'; 'vai na raça'; entre tantas outras que falam de uma certa identidade nacional ainda pautada por uma coloração singular. A raça continua, também, presente em sua asserção mais negativa, que busca vincular aspectos exteriores a certas 
deformações morais. É esse o discurso policial, a fala que preconceitua no cotidiano da violência.

São muitas faces que repõem o mesmo tema e que revelam, em seu conjunto, de que maneira o argumento racial é ainda operante como representação nacional. "Da cor da raça, cheiro e sabor", dizia o sambaenredo da Unidos de Salgueiro em 1992, como a comprovar que não estamos tão distantes das representações de finais do século passado. Afinal, nesse e em outros locais, o país é ainda desenhado, como dizia Nina Rodrigues, com uma certa cor 'interessante' e, nesse sentido, muito particular.
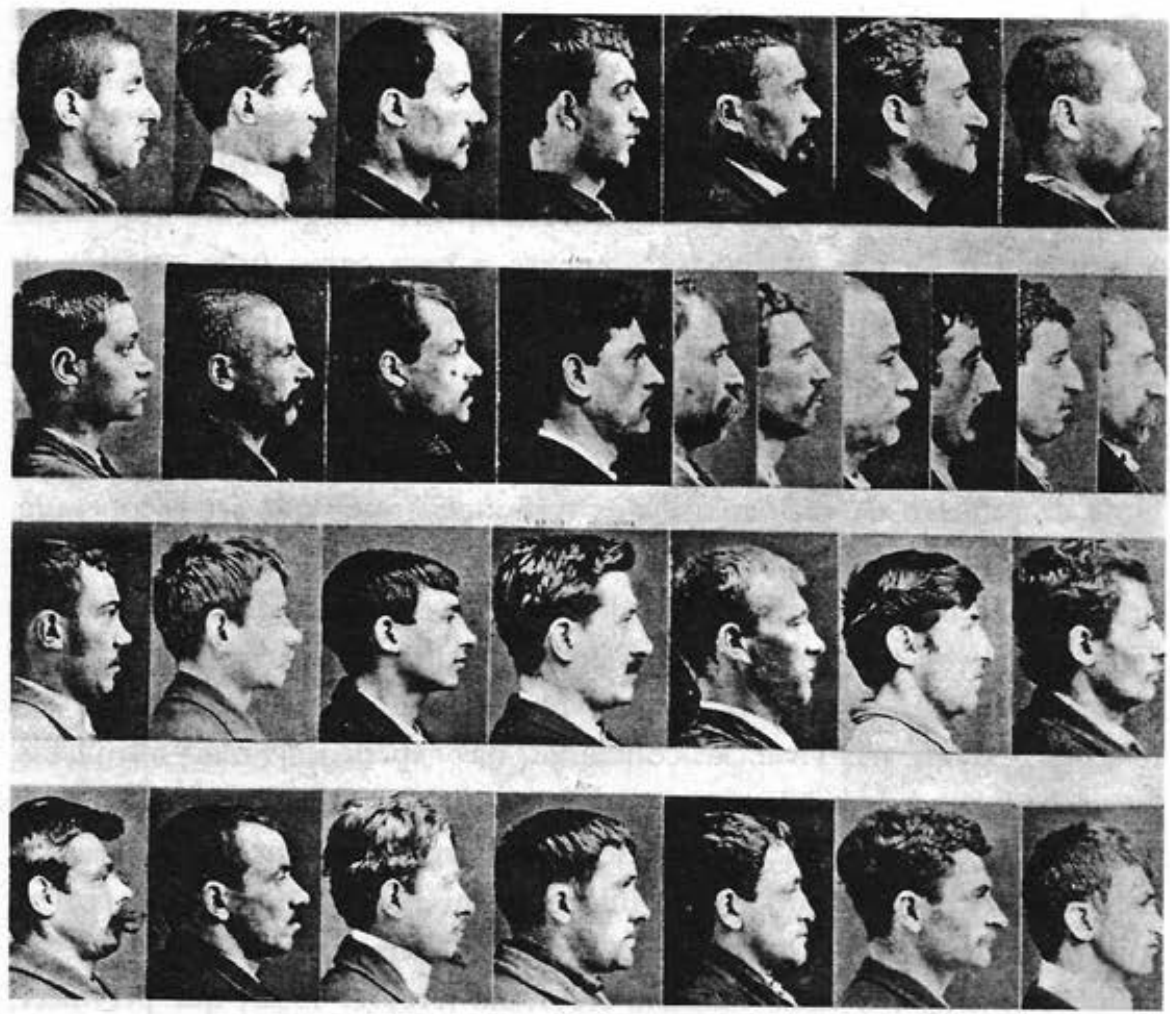

Quadro sinóptico de traços fisionômicos. Em destaque diferentes formatos de nariz 


\section{Notas}

1 A reflexão e o material que compõem boa parte deste artigo são oriundos de um trabalho mais abrangente, apresentado originalmente como tese de doutorado, com o título Homens de Sciencia e a Raça dos Homens: cientistas, instituições e teorias raciais no Brasil de finais do século XIX (Schwarcz, 1993). Este artigo foi publicado anteriormente na Revista Estudos Avançados (1994).

2 "Eu vi um fato singular (...)" (Tradução livre).

3 “(...) que observei somente no Brasil: foi a mudança que se operou na população pelos cruzamentos das raças, eles são filhos do sol" (Tradução livre).

4 As declarações de von Ihering acabaram gerando inúmeras reações, culminando na criação do Serviço de Proteção aos Índios e de Localização dos Trabalhadores Nacionais (SPILTN) e de uma política mais direta de proteção. Sobre o tema, ver também Borelli (1984).

5 Em 1895, em um quadro de 'demografia sanitária' publicado pela revista Brasil Médico (1896: 62), a incidencia de moléstias contagiosas era aterradora. Em primeiro lugar, no índice de mortalidade, constava a tuberculose - a peste branca - responsável por $15 \%$ das mortes no Rio de Janeiro. Seguiam-se, em ordem de grandeza, os casos de febre amarela, varíola, malária, cólera, beribéri, febre tifóide, sarampo, coqueluche, peste, lepra, escarlatina, os quais, representavam $42 \%$ do total das mortes registradas nessa cidade.

- A questão da delimitação ambígua existente no Brasil entre domínio público e privado, já foi tematizada, de formas diversas, por vários pensadores nacionais. Citamos aqui alguns: Holanda (1979); DaMatta (1981); Cândido (1993) e Vianna (1952).

\section{Referências Bibliográficas}

AGASSIZ, L. \& AGASSIZ, E. C. A Journey in Brazil. Boston: s. n., 1868.

AIMARD, G. Le Brésil Nouveau. Paris: Dentú, 1888.

AMERICANO, P. Anno XXVII, n. 9, mar. 1896, p. 398. (Discurso pronunciado no acto de collação de gráo)

ARENDT, H. The Oriflins of Totalitarism. Nova Iorque: Harvest, 1973.

BORELli, S. H. S. (Org.) Índios do Estado de São Paulo. São Paulo: Yankatu, 1984.

CÂNDIDO, A. O Discurso e a Cidade. São Paulo: Duas Cidades, 1993.

CORRÊA, M. As llusões da Liberdade: a escola Nina Rodrigues e a antropologia no Brasil, 1983.

Tese de Doutorado, São Paulo: Universidade de São Paulo.

CRUZ, O. Jornal do Comércio, 1904, p.9.

DAMATTA, R. Você sabe com quem está falando? Carnavais, Malandros e Heróis. 3.ed. Rio de Janeiro: Zahar, 1981.

DUMONT, L. Homo hierarchinus: essai sur le système de castes. Paris: Gallimard, 1966.

FREYRE, G. Casa Grande \& Senzala. Rio de Janeiro, José Olympio, 1930. 
HALL, M. Reformadores de classe média no Império brasileiro e a Sociedade Central de Imigração. Revista de História, 53 (105): 148-160, 1976.

HOBSBAWM, E. A Invenção das Tradiçóes. São Paulo: Paz e Terra, 1987.

HOLANDA, S. B. de. Raízes do Brasil. Rio de Janeiro: José Olympio, 1979. (1.ed., 1936)

LACERDA, J. B. de Sur le Métis au Brésil. Paris: Imprimerie Devougue, 1911.

MONTEIRO, J. Tupis, Tapuias e a História de São Paulo. Novos Estudos, Cebrap, 1992.

NOGUEIRA, M. A. As Desventuras do Liberalismo: Joaquim Nabuco, a monarquia e a república. Rio de Janeiro: Paz e Terra, 1984.

QUEIROZ, M. I. P. de. Identidade cultural, identidade nacional no Brasil. Tempo Social 1. São Paulo: Edusp, 1989.

RAEDERS, G. O Conde Gobineau no Brasil. 2.ed. Rio de Janeiro: Paz e Terra, 1988.

RODRIGUES, N. As Raf̧as Humanas e a Responsabilidade Penal no Brasil. Bahia: Progresso, 1959. (1.ed., 1933)

ROMERO, S. História da Literatura Brasileira. 4.ed. Rio de Janeiro: José Olympio, 1968. (1.ed., 1888)

SCHWARCZ, L. K. M. Homem de Sciencia e a Rạ̧a dos Homens: cientistas, instituị̧̄es e teorias raciais em finais do século XIX, 1993. Tese de Doutorado, São Paulo: Universidade de São Paulo.

VENTURA, R. Estilo tropical: história cultural e polêmicas literárias no Brasil. São Paulo: Companhia das Letras, 1991.

VIANNA, O. Populą̧öes Meridionais do Brasil. Rio de Janeiro: José Olympio, 1952. (1.ed., 1918).

\section{Periódicos}

Boletim do Museu Paraense (1894).

Boletim Médico (1910).

Brasil Médico $(1896,1910)$.

Correio Paulistano (1901, 1920).

Gazeta Médica da Bahia (1902, 1906, 1933).

Revista Acadêmica da Faculdade de Direito do Recife $(1914,1919,1922)$.

Revista da Faculdade de Direito de São Paulo (1906).

Revista do Instituto Histórico de São Paulo (1904).

Revista do Museu Paulista (1987). 


\section{O Positivismo Brasileíro na sombra do Darwínísmo: o grupo Idéia Nova em Desterro}

Thomas Glick

O positivismo não é uma filosofia estrito senso, mas é principalmente um conjunto de princípios gerais apropriados por indivíduos ou grupos para legitimar objetivos ideológicos intelectuais específicos ou políticos (Glick, 1989). Um dos problemas historiográficos referentes ao positivismo na América Latina tem sido uma muito rígida dicotomização entre variações do positivismo comteano e spenceriano.

No Brasil, por exemplo, se a corrente comteana define positivismo para Cruz Costa, o spencerismo faz o mesmo para Graham. Cada ideologia tem um grupo diferente de atores e, para cada um, 'positivismo' foi apresentado como a ideologia da República Velha. Tal afirmação também é verdade para o México, onde Leopoldo Zea descreveu o positivismo como se Darwin e Spencer nunca tivessem tido nenhum seguidor no país. A posição de ambos, Cruz Costa (1956) e Zea (1968), tem se mostrado unilateral. Em ambos os países, teóricos como Antonio Paim (1980) e Roberto Moreno (1984), respectivamente, têm mostrado que o positivismo de Comte foi seguido de uma variação do spencerismo. ${ }^{1}$

José Veríssimo e Silvio Romero estavam certos quando disseram que o movimento intelectual brasileiro começou em 1873 com a confluência de políticos republicanos e a substituição do positivismo comteano pelo darwinismo, specerismo e monismo germânico, isto é, darwinismo como interpretado por Ernest Haeckel (Lopes, 1997).

Neste artigo, olho para um grupo de positivistas darwinistas na ilha de Desterro (hoje chamada Florianópolis), no final do século XIX, com a finalidade de ilustrar algumas conclusões gerais sobre o positivismo na América Latina. Este foi um grupo de escritores e poetas que ganhou 
proeminência sob o lema 'Idéia Nova', quando o seu líder intelectual, o médico liberal Francisco Gama Rosa, tornou-se presidente da província de Santa Catarina, em agosto de 1883. Gama Rosa (1852-1918), nascido no Rio Grande do Sul, foi estudante no Liceu Provincial de Desterro entre 1862 e 1865, quando seu professor de matemática era Fritz Müller. ${ }^{2}$ Müller deixou uma rica descrição do sistema educacional da forma livre como operava no liceu naqueles anos:

Para alguém acostumado ao sistema educacional germânico, esta escola era alguma coisa interessante. Não havia obrigatoriedade de aulas, nem ao menos um curriculum definido. Os pais podiam matricular seus filhos nas aulas que eles mais gostavam, como nas nossas universidades alemãs. Um podia começar com o latim, outro com francês, um terceiro com matemática. Um frequentava apenas uma aula, outro duas, enquanto um terceiro podia estudar as quatro disciplinas oferecidas simultaneamente na escola. ${ }^{3}$ Alguns podiam estudar uma matéria no terceiro ano, outro [a mesma matéria] no segundo ano, um terceiro no primeiro. Assim, era extremamente difícil organizar um esquema que tornasse possível para cada estudante ter os cursos que quisesse. ${ }^{4}$

Além do mais, o corpo de estudantes era muito pequeno, proporcionando um contato estreito e informal entre professores e alunos. Em tal ambiente, é fácil entender como o jovem Gama Rosa pôde absorver a visão de Müller sobre o liberalismo, livre pensamento e - mais importante - evolução, particularmente a visão de Haeckel, quando ele era ainda um jovem estudante. Gama Rosa foi aluno de Müller no importante ano de 1863 - em que a sua clássica apologia pela evolução, Für Darwin, foi publicada. De acordo com Magalhães Junior (1971), Gama Rosa foi partidário das idéias de Fritz Müller e foi correspondente de Haeckel e Spencer.

Gama Rosa resume suas idéias sobre evolução no seu livro, Biologia e Sociologia do Casamento (Cruz e Souza, 1995), no qual ele cita Darwin e Spencer. ${ }^{5}$ Gama Rosa liderou um revival intelectual em Desterro; seu círculo incluía vários integrantes do grupo Idéia Nova: Virgílio Várzea (18631941), João Cruz e Sousa (1861-1898), Manuel dos Santos Lostada (18601923), Oscar Rosas (1862-1925) e Eduardo Nunez Pires (1854-1950), todos de Desterro. ${ }^{6}$ Ele tornou-se presidente do governo provincial com 31 anos de idade e chamou Várzea para seu gabinete, tendo ficado impressionado pelo seu soneto, "Transformismo".

O soneto foi publicado no jornal diário O Despertador. Na pesquisa feita em uma série incompleta em Florianópolis, não consegui encontrar o 
poema, nem em publicação subseqüente. Entretanto, é claro que, neste tempo, Várzea utilizou "Transformismo" como um termo poético. Assim, em um soneto publicado no dia 11 de janeiro de 1884, em A Regeneração, Várzea dizia:

E as denegridas portas do Inferno

São abertas já - lavas lançando

Entre chufas d'alegre transformismo! ??

Que há de mais belo e mais moderno

Ali, s'encontro tudo em bom comando

De Plutão a força e mecanismo!

A livre apropriação de termos ligados à ciência, como transformismo e mecanicismo, leva a induzir uma aura positivista em linguagem poética. Transformismo é um termo que Várzea pode somente ter adquirido pela leitura de livros sobre evolução em francês.

Em termos gerais, o grupo Idéia Nova favoreceu o realismo e o naturalismo em oposição ao romantismo, justificando essa perspectiva na biologia evolucionista e na ciência social. Seus membros publicaram poesia e alguns artigos programáticos no jornal do partido liberal, A Regeneração, fundado em 1868. As séries consultadas em Florianópolis não estão completas. Eu não encontrei menção a Darwin em artigos publicados entre 1868-1871 e 1877-1878..$^{7}$ Alusões casuais a Darwin (ao contrário de artigos tratando especificamente de Darwin ou evolução) não apareceram neste jornal antes da metade dos anos 1880, anos em que Várzea mais ativamente promoveu a mensagem positivista do Idéia Nova. Em 10 de janeiro de 1884, apareceu em A Regeneração um soneto de Várzea dedicado a Santos Lostada. Como seu título - "Alerta!" - indicava, era um cri de guerre, zombaria no combate contra o romantismo - o inimigo - e a favor do evolucionismo, com heróis e vilões claramente identificados:

Batamos forte o velho romantismo

Que o século é puramente de evolucionismo,

De Hartmann, de Spencer, Zola e Letourneau.

Batamos rígidamente os tontos pessimistas,

Que o século é de gigantes, d'assombrar e conquistar

E não de Auguste Comte, de Dumas ou Hugo.

(...) 
Antes de proceder, gostaria de fazer duas observações. Primeiro, a oposição Hugo/Zola era lugar comum na literatura dos círculos positivistas e Charles Letourneau - um antidarwinista, antropólogo lamarckista - pode somente ter sido listado para dar rima para Hugo. Segundo, Várzea não hesitou em brandir Comte como um romântico. Os escritores do Idéia Nova eram specerianos e seu corte com Comte foi, em geral, radical.

Em 12 de março de 1884, A Regeneração imprimiu uma carta anônima sobre o poeta Pinheiro Chagas. A carta foi um manifesto do Idéia Nova e pode ter sido escrita por Várzea. O autor começa observando que o mundo de idéias evolui da mesma forma que o mundo biológico, então:

A Idea Nova não conhece fetiche, adiante de si só tem a Justiça. Não obscurece
o mérito de escritor algum, nem a influência que ele pode exercer no seu
tempo. Somente, sabendo que a intelectualidade evolui, como evoluiu o
mundo biológico, não permite que as idéias e a linguagem de uma escola do
passado venham perturbar a exclusão e o desenvolvimento de concepção
estética e científica atual. $^{8}$

Os fósseis, portanto, tinham de ser reconhecidos como tais. Chagas, o autor continua, tinha se desenvolvido como um escritor sob a influência do romantismo em sua mais exagerada fase, o que explica o lirismo banal e unilateral do poeta. Ele é um homem do passado. Então, para deixar claro quais figuras pertenciam ao passado e quais ao presente, o escritor forneceu uma lista de românticos vilões e heróis positivistas:

Os grandes nomes da Idea Nova não podem ser certamente Victor Hugo, Lemartine, Cousin, Chateaubriand, Garrett, Castilho, Herculano, Casimiro d'Abreu, Gonçalves Dias, os homens do passado; mas unicamente Darwin, Spencer, Hartmann, Taine, Zola, Daudet, Richepin, Eça de Queiroz, Ramalho Ortigão, Guerra Junqueiro, Guilherme de Azevedo, Valentin Magalhães, João Capistrano, Raul Pompéia, os fortes da atualidade.

Entre escritores cientistas, Darwin e Spencer eram, naturalmente, obrigatórios; Hartmann e Taine, figuras francesas representativas, eram ordenados na mesma linha. Eduard Hartmann tentou efetivar uma reconciliação entre ciência natural e teologia e foi assim lido pelos positivistas em todos os países católicos. Hippolyte Taine - 'o maior sacerdote do determinismo e do materialismo' - trouxe perspectivas evolucionistas para impô-las sobre a crítica literária, embora ele fosse influenciado mais por Geoffroy Saint-Hilaire do que por Darwin. ${ }^{9} \mathrm{O}$ único conhecimento de autores ingleses acessível ao grupo Idéia Nova veio através de traduções francesas. ${ }^{10}$ 
O mais conhecido membro do grupo Idéia Nova de Desterro foi o poeta João Cruz e Sousa. Seu alto grau de identificação com o evolucionismo levanta a questão de ele ter sido influenciado diretamente por Fritz Müller, bem como a mais ampla questão de que a extensão da visão de Müller pode ter atingido a 'inteligentsia' de Santa Catarina.

Müller emigrou para o Brasil em 1852, era professor de matemática no Liceu Provincial de Desterro - a única escola secundária da província entre 1856 e 1867, quando a escola foi dissolvida. ${ }^{11}$ É importante entender a natureza dessa escola e o papel de Müller nela, porque seu tão alto perfil, bem como sua atividade específica, torna plausível sua influência sobre a 'inteligentsia' da cidade. Müller foi indicado para o Liceu quando da sua criação em 1856, tendo sido consultado sobre sua organização pelo presidente da província, João José Coutinho; os primeiros cursos começaram no início de 1857. Há algumas evidências de que Müller olhava o liceu como sua criação e até mesmo plantou um jardim botânico em seu terreno. Além de matemática, ele lecionava para estudantes avançados em química e física, tendo recebido muitos instrumentos da Alemanha.

Quando o liceu foi fechado, Müller permaneceu na folha de pagamento e ganhou permissão para residir em Itajaí e continuar os estudos botânicos como representante do governo provincial. ${ }^{12}$ Ele foi ainda professor de matemática na instituição sucessora - Ateneu Provincial de julho de 1874 até outubro de 1876 , quando foi nomeado viajante naturalista do Museu Nacional. ${ }^{13}$

Houve um debate sobre se o fato de Cruz e Sousa ser um homem negro, como Müller mencionou numa carta a seu irmão Hermann, reforçou sua opinião de que a capacidade intelectual dos negros não era inferior a dos brancos. É quase certo, no entanto, que a carta foi escrita em 1860; antes, portanto, do nascimento de Cruz e Sousa. ${ }^{14}$ A verdade é que Cruz e Sousa foi estudante no liceu em 1874, embora os registros mostrem que ele não foi examinado em matemática. A evidência da transmissão direta das idéias evolucionistas para o poeta, por Müller, dessa forma, permanece circunstancial. ${ }^{15}$

A inserção de Cruz e Sousa na corrente positivista é clara pela lista de heróis nas linhas iniciais do seu soneto "A Revolta" (1995: 235):

O século é de revolta - do alto transformismo,

De Darwin à Littré, de Spencer, de Laffite (...). 
Émile Littré (1801-1881) foi um positivista que divergiu de Comte, dizendo que, no fim, ele adotou uma metodologia subjetiva. Pierre Laffite foi inimigo de Littré, líder dos comteanos ortodoxos; nenhum foi evolucionista. Cruz e Sousa não foi tão cuidadoso quanto Várzea na separação dos comteanos do panteon dos posivistas. Porém, foi desde o início de sua carreira um darwinista, fortemente influenciado por Haeckel. Uma revisão, em um de seus primeiros livros, Tropas e Fantasias, escrito em colaboração com Várzea, identifica os autores como "discípulos incorruptíveis da Escola Naturalista, educados rijidamente nas teorias de Darwin, Spencer, Hartmann, Haeckel e outros" (Magalhães Jr.,1971: 72).

Cruz e Sousa estava numa posição pouco invejável, pois tinha de confrontar sua inferioridade social como negro que era, mesmo aceitando as insinuações darwinistas de sua proximidade racial com seus ancestrais simiescos: "Tu vens exata e diretamente do Darwin", ele se divertia parado diante de um espelho, "da forma ancestral comum dos seres organizados: eu te vejo bem as saliências cranianas do Orango, o gesto lascivo, o ar animal e rapace do símio" (Cruz e Sousa, 1995: 473). No livro Descent of Man (1981), Darwin detalhou similaridades entre o homem e os macacos, o orangotango em particular. Quando jovem, Cruz e Sousa aguentou provocações dos seus companheiros, que chamavam seu pai de "o elo perdido" (Haberly, 1983: 102).

Alguns dos melhores comentários do positivismo de Idéia Nova provêm de Cruz e Sousa, numa revisão ao livro de Gama Rosa sobre a biologia e a sociologia do casamento. ${ }^{16}$ Ele começava por comparar o autor com Spencer: "Entre as obras de Herbert Spencer e as produções do ilustre dr. Gama Rosa encontramos o mesmo tom de conjunto, os mesmos traços gerais, os mesmos golpes de observação e de crítica científica, a mesma serenidade idealizadora". Gama Rosa, com efeito, capturou o "caráter pacificamente frio e pensador da raça anglo-saxônica" (1995: 760). Ele descreve a familia como um organismo que necessita permitir-se desenvolver para lidar, com sucesso, com os problemas colocados pela vida moderna. Para ambos há bases biológicas e sociais para o casamento civil com previsão para o divórcio. Cruz e Sousa ponderava para invocar o volume de Spencer sobre educação física e intelectual ${ }^{17}$ como a base para a introdução da filosofia aplicada na educação brasileira. O que Gama Rosa fez, continua o revisor, foi aplicar os princípios do darwinismo com o fim de mostrar que as práticas do casamento católico estavam em descompasso com a 
seleção natural, ou seja, uma sociedade corrupta introduziu uma espécie de seleção artificial em que as classes privilegiadas distorciam as leis da natureza para sua própria vantagem. ${ }^{18}$

Em conclusão, muito se tem escrito sobre o positivismo brasileiro e a influência de darwinistas como Fritz Müller. Penso que estudos recentes são suficientes para expor a fragilidade de argumentos que clamam a preeminência, no Brasil, da variedade positivista de Comte, e urgem estudos sobre a influência de Darwin e Spencer.

\section{Notas}

1 Ver Graham (1958). Embora Cruz Costa reconheça um apelo a Spencer, especialmente nas classes profissionais, ele dá muito maior importância à influência de Comte.

2 Como ele lembrou em uma memória escrita antes da morte de Müller - Gama Rosa (1965-66).

3 As quatro disciplinas oferecidas eram matemática, latim, francês e inglês.

4 Sobre Müller e o liceu, ver sua declaração autobiográfica - Müller (1983) traduzido do original alemão publicado em Asland (Stuttgart) em 1892; Castro (1992) e Silva (1957-58).

s Há também uma tradução (feita por Max Nordau) francesa deste trabalho. Não consegui localizar nenhuma cópia.

- Ver Piazza (1983). Cruz e Sousa forneceu uma lista diferente, mais ampla e mais recente, de pessoas que ele considerou serem parte do movimento, numa carta a Gonzaga Duque de 1894 , na qual ele afirma que "o único homem fora de nossa linha artística de seleção relativa possível, que deve ser simpaticamente admitido, para críticas científicas para artigos de caráter positivo moderno, é o dr. Gama Rosa, que podemos considerar, à parte toda a nossa independência e rebelião, como austero e curioso Patriarca do novo Pensamento" (Muzart, 1993). Num jornal local, Várzea anunciou, para publicação, um livro intitulado Um Filósofo Brasileiro: ensaios científicos sobre o dr. Gama Rosa, o qual, aparentemente, nunca foi publicado.

7 Em 1877-1878 havia freqüentes menções a Thomas Edison e Alexander Graham Bell. As notícias sobre inovaçōes tecnológicas neste período geralmente são caracterizadas por muito alta divulgação, de disseminação muito rápida. A respeito da cobertura nos jornais de Edison em Montevidéu neste período, ver Glick (1994).

8 A noção de que as idéias evoluem é provavelmente derivada do livro de Taine (1870).

- Compare esta lista de heróis com a de Silvio Romero (1895: 81): Hume, Kant, Adam Smith, Diderot, Hamilton, Darwin, Spencer, Hartmann, Helmholtz, Huxley, Haeckel, Noiré. Sobre Taine, ver Clark (1984). 
v Numa pesquisa em dossiês não catalogados na Biblioteca Municipal de Florianópolis, não encontrei títulos de Darwin. Trabalhos de Spencer (1871, 1878, 1882, 1887, 1890a, 1890b): livros de Huxley (1882, 1891a, 1891b, 1892). O último título e alguns outros levantados eram originários da biblioteca de Pedro Ferreira, presidente da província. Opiniōes positivistas sobre educação eram o centro dos interesses dos positivistas latino-americanos em geral. Também encontrei trabalhos de Buckle e Taine.

n. Müller não foi demitido por sua visão darwinista, como disse Hugo Gensch (1986), um necrologista. Nelson Papavero (1973) também diz que Müller foi demitido por 'insignificante razão política'. Mais tarde, Papavero \& LLorente-Busquets (1996) afirmam que ele lecionou no liceu de 1856 a 1867.

n Relatório apresentado ao Exmo. Presidente da Província de Santa Catarina (Desterro, J. A. do Livramento, 1867 , p. 6): “Ao dr. Müller concedi permissão para residir em Itajahy, ponto por ele escolhido para principiar as explorações e estudos a seu cargo, e aonde, em terras suas, tem de ensaiar o plantio e cultura das plantas exóticas e indígenas, com emprego na indústria".

B Já no fim da sua vida, em 1889, Müller retornou às aulas como professor de história natural no Neue Deutsche Schule, na colônia alemã de Blumenau, onde viveu Killian (1989).

4 A evidência é obtida em Magalhães Jr. (1971: 7).

• Müller escrevia em português e inglês com perfeição. Pode-se presumir que seu português era fluente e que a linguagem não seria uma barreira para conduzir uma conversação informal sobre tópicos científicos.

1 Biologia e Sociologia do Casamento. Cruz e Sousa sobre Gama Rosa (1995: 760-762).

v Sobre a importância deste livro no Brasil, ver Graham (1958: 242; s.d.). O trabalho era bem conhecido em Desterro, ver nota 10 .

w Este foi um argumento comum e liberal do social darwinismo que assegurou que a aristocracia de uma espécie ou outra contrariava as leis do progresso e da evolução, substituindo o privilégio por uma aptidão natural. Ver Glick (1988).

\section{Referências Bibliográficas}

CASTRO, M. W. de. O Sábio e a Floresta. Rio de Janeiro: Rocco, 1992.

CLARK, L. L. Social Darwinism in France. Alabama: University of Alabama Press, 1984.

COSTA, J. C. O Positivismo na República. São Paulo: Editora Nacional, 1956.

CRUZ E SOUSA, J. Obra Completa. Rio de Janeiro: Nova Aguilar, 1995.

DARWIN, C. Descent of Man. Princeton: Princeton University Press, 1981.

GAMA ROSA, F. Uma opinião sobre Fritz Müller. Blumenau em Cadernos, 7: 4-5, 1965-66.

GENSCH, H. A memória do dr. Fritz Müller [1990]. Blumenau em Cadernos, 27: 202-206, 1986.

GLICK, T. F. Spain: the comparative reception of darwinism. 2.ed. Nova Iorque: University of

Chicago Press, 1988. 
GLICK, T. F. Darwin y el Darwinismo en el Uruguay y en America Latina. Montevideo: Universidad de la Republica, 1989.

GLCK, T. F. Edison: mito y realidad. Arbor, 148: 39-50, 1994.

GRAHAM, R. Educação Moral e Physica. Porto: Livraria Moderna, s.d.

GRAHAM, R. Britain and the Onset of Modernization in Brazil, 1850-1914. Cambridge: Cambridge University Press, 1958.

HABERLY, D. T. Three Sad Races: racial identity and national consciousness in brazilian literature. Cambridge: Cambridge University Press, 1983.

HUXLEY, T. H. Physiographie. Paris: Ballière, 1882.

HUXIEY, T. H. Les Sciences Naturelles et L'Éducation. Paris: Ballière, 1891a.

HUXLEY, T. H. La Place de L'Homme dans La Nature. Paris: Ballière, 1891b.

HUXLEY, T. H. Problèmes de Biologie. Paris: Ballière, 1892.

KILLLAN, F. Subsídio à história da 'Escola Nova' de Blumenau. Blumenau em Cadernos, 30: 44-45, 1989.

LOPES, M. M. O Brasil Descobre a Pesquisa Científica: os museus e as ciências naturais no século $X I X$. São Paulo: Hucitec, 1997.

MAGALHÃES JR., R. Poesia e Vida de Cruz e Sousa. São Paulo: Lisa, 1971.

MORENO, R. La Polemica del Darwinismo en México. México: Unam, 1984.

MÜLER, A vida de Fritz Müller narrada por ele mesmo. Cadernos de Blumenau, 24: 129-136, 1983.

MUZART, Z. Cartas de Cruz e Souza. Florianópolis: Letras Contemporâneas, 1993.

PAIM, A. Iniciadores do término do ciclo positivista. Revista Brasileira de Filosofia, 30: 335 $349,1980$.

PAPAVERO, N. Essays on the History of Neotropical Dipterology. São Paulo: Museu de Zoologia, 1973.v.2.

PAPAVERO, N. \& LLORENTE-BUSQUETS, J. Principia Taxonômica, VI: la taxonomía evolutiva. México City: Coordinación de Servicios Editoriales, Facultad de Ciencias, Universidad Nacional Autónoma de México, 1996.

PIAZZA, W. F. Santa Catarina: sua história. Florianópolis: UFSC, 1983.

ROMERO, S. Doutrina contra Doutrina: o evolucionismo e o positivismo no Brasil. 2.ed. Rio de Janeiro: Alves, 1895.

SILVA, J. F. Fritz Müller e o presidente Coutinho. Blumenau em Cadernos, 1: 143-146, 1957-58. SPENCER, H. Premiers Principes. Paris: Alcan, 1871.

SPENCER, H. Principes de Biologie. Paris: Ballière, 1878, 2v.

SPENCER, H. De L'Éducation Intelectuelle, Morale et Physique. Paris: Alcan, 1882.

SPENCER, H. Principes de Sociologie. Paris: Félix Alcan, 1887.

SPENCER, H. Principes de Sociologie. Paris: Félix Alcan, 1890a.

SPENCER, H. Essai de Politique. 3.ed. Paris: Félix Alcan, 1890b. v.2

TAINE, H. De l'Intelligence. s.l.: s.n. 1870.

VÁRZEA, V. Alerta. A Regeneração, 10 jan. 1884.

ZEA, L. El Positivismo en México. México: Fondo de Cultura Ecónomica, 1968. 